\title{
Kwaliteitsconcurrentie tussen ondernemingen : een empirisch onderzoek naar produktkwaliteitsverbeteringen van industriele ondernemingen, marketing-mix reacties van concurrenten en gepercipieerd succes
}

Citation for published version (APA):

Lemmink, J. G. A. M. (1991). Kwaliteitsconcurrentie tussen ondernemingen : een empirisch onderzoek naar produktkwaliteitsverbeteringen van industriele ondernemingen, marketing-mix reacties van concurrenten en gepercipieerd succes. [Doctoral Thesis, Maastricht University]. Rijksuniversiteit Limburg. https://doi.org/10.26481/dis.19910613jl

Document status and date:

Published: 01/01/1991

DOI:

10.26481/dis.19910613jl

Document Version:

Publisher's PDF, also known as Version of record

Please check the document version of this publication:

- A submitted manuscript is the version of the article upon submission and before peer-review. There can be important differences between the submitted version and the official published version of record. People interested in the research are advised to contact the author for the final version of the publication, or visit the DOI to the publisher's website.

- The final author version and the galley proof are versions of the publication after peer review.

- The final published version features the final layout of the paper including the volume, issue and page numbers.

Link to publication

\footnotetext{
General rights rights.

- You may freely distribute the URL identifying the publication in the public portal. please follow below link for the End User Agreement:

www.umlib.nl/taverne-license

Take down policy

If you believe that this document breaches copyright please contact us at:

repository@maastrichtuniversity.nl

providing details and we will investigate your claim.
}

Copyright and moral rights for the publications made accessible in the public portal are retained by the authors and/or other copyright owners and it is a condition of accessing publications that users recognise and abide by the legal requirements associated with these

- Users may download and print one copy of any publication from the public portal for the purpose of private study or research.

- You may not further distribute the material or use it for any profit-making activity or commercial gain

If the publication is distributed under the terms of Article $25 \mathrm{fa}$ of the Dutch Copyright Act, indicated by the "Taverne" license above,

Download date: 26 Apr. 2023 


\section{Kwaliteitsconcurrentie tussen ondernemingen}

Een empirisch onderzoek naar produktkwaliteitsverbeteringen van industriële ondernemingen, marketing-mix reacties van concurrenten en gepercipieerd succes 
अ: $: 494$

ब में

म.

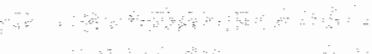

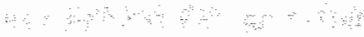

a : 


\section{Kwaliteitsconcurrentie tussen ondernemingen}

Een empirisch onderzoek naar produktkwaliteitsverbeteringen van industriële ondernemingen, marketing-mix reacties van concurrenten en gepercipieerd succes

\section{PROEFSCHRIFT}

ter verkrijging van de graad van doctor aan de Rijksuniversiteit Limburg, op gezag van de Rector Magnificus, Prof.mr. M.J. Cohen, volgens het besluit van het College van Dekanen, in het openbaar te verdedigen op donderdag, 13 juni 1991

om 14,00 uur

$$
\text { door }
$$

Johannes Gerhard Alfons Marie Lemmink 
Promotor:

Prof. dr. J.D.P. Kasper

Beoordelingscommissie:

Prof. dr. J. Hagedoorn (voorzitter)

Open Universiteit / Rijksuniversiteit Limburg

Prof. dr. J. de Rijcke

Rijksuniversiteit Gent

Prof. dr. H. Schreuder

Rijksuniversiteit Limburg

CIP-GEGEVENS KONINKLIJKE BIBLIOTHEEK, DEN HAAG

Lemmink, Johannes Gerhard Alfons Marie

Kwaliteitsconcurrentie tussen ondernemingen : een empirisch onderzoek naar produktkwaliteitsverbeteringen van industrièle ondernemingen, marketing-mix reacties van concurrenten en gepercipieerd succes / Johannes Gertuard Alfons Marie Lemmink, - Maastricht: Datawyse, III.

Proefschrift Masstricht. - Met lit. opg.

ISBN $90-5291<055-3$

NUGI 686

Trefw.: Kwaliteitsconcurrentie ; ondememingen

(C) 1991 Jos Lemmink, Maastricht

Omslagontwerp: Sharon Siep

Druk: Datawyse Maastricht / Krips Repro Meppel 


\section{Voorwoord}

De eerste ideeën om een proefschrift te schrijven over kwaliteitsconcurrentie kwamen al op in de loop van 1986. Vrij snel hebben deze ideeên geleid tot het opzetten en uitvoeren van een empirisch onderzoek. Eerst in de vorm van een pilot-studie in 1986, later in de vorm van een grootschaliger schriftelijk onderzoek eind $1987 /$ begin 1988. Dit boek vormt het eindverslag van het onderzoek.

In de loop van de jaren hebben veel collega's, maar ook anderen op én of andere wijze meegewerkt en meegedacht. Ik wil al diegenen die zich voor mij hebben ingespannen heel hartelijk bedanken. Met name wil ik noemen de (ex) student-assistenten die vooral hebben bijgedragen aan de literatuurstudie, de uitvoering van het veldwerk, het aandragen van de koffie, de verwerking van de gegevens en de vervolmaking van het manuscript. In chronologische volgorde zijn dat drs. Patrick Jaspers, drs. Victor Herfs, drs. René Vogels en Joël Gijzen, die met name in de laatste fasen behulpzaam is geweest. Vervolgens ben jk dank verschuldigd aan de personen die hebben geholpen bij het snel en effectief benaderen van ondernemingen ten behoeve van het veldwerk. Dat zijn met name de leden van het bestuur van de Regionale Kwaliteitskring Zuid Limburg ir. Jan Cottaar (voorzitter) en Pieter Utens (Kamer van Koophandel Heerlen). Voor bijdragen in een latere fase van het onderzoek ben ik dank verschuldigd aan de voorzitter van de Regionale Kwaliteitskring Noord-Oost Brabant, ir. Ben de Bruin die consciëntieus de classificatie van produktkwaliteitsverbeteringen heeft uitgevoerd. Verder wil ik drs. Ton Kuylen (Postbank, Amsterdam) en dr. Peter de Gijsel (RL) bedanken voor het doorlezen van specifieke passages in het proefschrift ten aanzien van respectievelijk statistische en micro-economische aspecten. Mijn dank gaat eveneens uit naar de Stichting Kwaliteitsdienst KDI Rotterdam die door haar sponsoring de uitgave van dit boek in deze vorm mede mogelijk heeft gemaakt. Ik bedank de leden van de sectie Marketing \& Marktonderzoek voor de goede werksfeer waarin mijn onderzoek kon worden voltooid.

Speciale dank gaat uit naar mijn promotor prof.dr. Hans Kasper, die met name in de afrondingsfase van het onderzoek, zeer stimulerend en behulpzaam is geweest. Uiteraard dank ik ook de leden van de beoordelingscommissie, die mijns inziens nauwgezet het manuscript hebben bestudeerd; prof.dr. John Hagedoorn, prof.dr. Jacques de Rijcke en prof.dr. Hein Schreuder.

Tot slot ben ik, ondanks het feit dat het nogal obligaat klinkt, er werkelijk van overtuigd dat mijn gezin de grootste inspanning heeft geleverd door mij in staat te stellen het dissertatie-onderzoek af te ronden. Marian, Lotte en Ester; aan jullie is dit boek opgedragen! 



\section{Inhoudsopgave}

Voorwoord

Inleiding en probleemstelling

1. De context van kwaliteitsverbeteringen en concurrentie 5

1.1. Het recente kwaliteitsdenken 5

1.2. Concurrentie $\quad 7$

1.2.1. Micro-economische invalshoek $\quad 7$

1.2.2. Marketing invalshoek $\quad 7$

1.3. Kwaliteit en concurrentie 10

2. Uitgangspunten en definities 13

2.1. Definitie van produkt 13

2.2. Belangrijke aspecten in de definitie van kwaliteit 14

2.2.1. Vijf optieken voor het bestuderen van kwaliteit 16

2.2.2. Een nadere beschouwing van de produktgerichte benadering 20

2.3. Kwaliteitskostenverloop en kwaliteitsniveau 27

2.4. Overzicht van kwaliteitsdefinities in de managementliteratuur 31

2.4.1. Kwaliteitszorg en marketing 31

2.4.2. Kwaliteitsmanagement en marketing-management 32

2.4.3. Interne en externe kwaliteitszorg

2.4.4. Classificatie van kwaliteitsdefinities $\quad 33$

2.5. Kwaliteit gemeten $\quad 36$

2.6. Produktkwaliteitsverbeteringen (PKV'n) 39

2.6.1. PKV of nieuw produkt? 39

2.6.2. PKV' $n$ en kwaliteitsverbeteringen in het produktieproces $\quad 40$

2.6.3. Strategische versus operationele beslissingen ten aanzien
van $P K V " n$

3. Produktkwaliteitsverbeteringen en concurrentiële reacties 43

3.1. Ondernemingsstrategie, kwaliteitsstrategie en PKV'n 43

3.2. Verschillende soorten produktkwaliteitsverbeteringen (PKV'n) 44

3.2.1. Het multidimensionale kwaliteitsbegrip bij een micro-economische benadering 45

3.2.2. Soorten PKV'n volgens Abbott 46

3.2.3. Marketing-tekstboeken en soorten PKV'n 46

3.2.4. Indeling in soorten PKV'n volgens Garvin 47

3.2.5. Andere aanzetten tot een indeling in soorten PKV'n 47 
3.3. De reacties van concurrenten 48

3.3.1. Micro-economische benadering van reacties van de concurrent 48

3.3.2. Enkele empirische resultaten ten aanzien van concurrentielle reacties

3.4. Parallellen met onderzoek uit de "industriële economie" en econometrische marketing modellering

3.4.1. Algemeen 51

3.4.2. Het meten van de intensiteit van de concurrentiele reactie 53

3.4.3. Hypothesen omtrent concurrentiele reacties uit de literatuur 54

3.4.4. Parallellen met reacties van concurrenten op PKV'n en conclusies 57

4. Produktkwaliteitswerbeteringen en reacties van concurrenten: model en hypothesen

4.1. Model voor PKV'n en concurrentièle reactie

4.1.1. Kenmerken van de onderneming, de marketing-strategie en de markt

4.1.2. Aanleidingen voor het aanbrengen van PKV'n 63

4.1.3. Produktkwaliteitsverbeteringen

4.1.4. Reacties van de meest belangrijke concurrent

4.1.5. Het gepercipieerde resultaat van de kwaliteitsverbetering $\quad 68$

4.2. Hypothesen voor het empirisch onderzoek

5. Opzet van het empirisch onderzoek en profiel van de populatie $\quad 77$

5.1. Opzet van de steekproef $\quad 77$

5.2. Profiel van de totale populatie $\quad 78$

5.3. Selectie van een produkt/markt combinatie. $\quad \cdots \quad \div \quad 79$

5.4. Profielen van de ID-groep en de CND-groep $\quad: \quad 81$

5.5. Conclusies $\quad 83$

6. Resultaten van het empirisch onderzoek in grote lijnen 85

6.1. Aanleidingen voor PKV'n, reacties van concurrenten en gepercipieerde resultaat: de totale groep van ondernemingen

6.1.1. Aanleidingen voor PKV'n

6.12. Reacties van concumenten op Ph

6.1.3. Het gepercipieerde resultat van PKV'n $\quad 86$

$\begin{array}{ll}\text { 6.1.4. Conclusies } & 86\end{array}$

6.2. Aanleidingen voor $\mathrm{PKV}$ ' $\mathrm{n}$, reacties van concurrenten en gepercipieerde resultaat: verschillen tussen de ID- en CND-groep

6.2.1. Aanleidingen voor PKV'n in de ID- en CND-groep

6.2.2. Verschillen tussen reacties van concurrenten op PKV'n in de ID-en de CND-groep

6.2.3. Verschil tussen het gepercipieerde resultaat in de ID-groep en de CND-groep

6.3. Resultaten en interpretatie van de conclusies 
7. De resultaten voor de produktkwaliteitsverbeteringen in de industriële markt van duurzame produkten in detail

$\begin{array}{ll}\text { 7.1. Produktkwaliteitsverbeteringen } & 95\end{array}$

7.2. Reacties van de concurrent 99

7.2.1. Inventarisatie van concurrentiële reacties 99

7.2.2. Produktlevenscyclus en concurrentiële reacties 101

7.2.3. Soorten PKV'n en concurrentiële reacties 103

7.2.4. Invloed van de marktaandeelwinst als gevolg van een PKV en de intensiteit van de concurrentiele reactie 108

7.2.5. Multivariate analyse voor de verklaring van de intensiteit $\begin{array}{ll}\text { van de reactie } & 109\end{array}$

7.2.6. Conclusies ten aanzien van concurrentiële reacties 111

7.3. De relatie tussen aanleidingen, PKV'n en soorten reacties nader bekeken 113

7.4. Het gepercipieerde resultaat van PKV'n 120

7.4.1. Verbetering van marktaandeel en netto resultaat als gevolg van PKV'n

7.4.2. Multivariate analyse voor de verklaring van de marktaandeelwinst en het netto resultaat

7.4.3. Conclusies ten aanzien van het succes van PKV' $n$ in termen van marktaandeel en netto resultaat

7.5. Conclusies ten aanzien van PKV" $n$ in een industriële markt

8. Mogelijke verklaringen en suggesties voor verder onderzoek

8.1. De kenmerken van de ondernemingen

8.2. Oligopoloïde markten en reactie-intensiteit

8.3. Fase in de produktlevenscyclus en reactie-intensiteit

8.4. Produktkwaliteitsverbeteringen en reactie-intensiteit

8.5. Het succes van produktkwaliteitsverbeteringen

8.6. Markttoetredingen en produktkwaliteitsverbeteringen

8.7. Marktgerichte produktkwaliteitsverbeteringen

8.8. Suggesties voor verder onderzoek

Bijlage A. Definities van kwaliteit in de managementliteratuur

Bijlage B. De multidimensionaliteit van het kwaliteitsbegrip en de reacties van de concurrent: micro-economische benadering

Bijlage C. Verantwoording ten aanzien wan de onderzoeksopzet, de pilot-studie en de steekproef

C.1. Pilot-studie en voorbereiding definitieve onderzoek 151

C.2. Steekproefkader Regionale Kwaliteitskringen 151

C.3. Steekproefkader N.V. Databank 152

C.4. Verloop van het veldonderzoek 153

C.5. Respons en non-respons 154 
Bijlage E. Profiel van de respondenten in het empirisch onderzoek

Bijlage F. Resultaten van het empirisch onderzoek

Bijlage G. Categorie-indeling van de door de respondenten verstrekte omschrij vingen van de produktkwaliteitsverbeteringen

Bijlage H. Verantwoording van de uitkomsten van de multivariate analysetechnieken; regressie-analyse en discriminant-analyse

H.1. De verklaring van de reactie-intensiteit met behulp van een meervoudige regressie-analyse

H.2. De bepaling van het belang en de invloed van de modelvariabelen voor het succes van de PKV: een discriminant-analyse

Literatuur

Summary 


\section{Inleiding en probleemstelling}

\section{Inleiding}

Uit nationale en internationale ontwikkelingen op het gebied van de kwaliteitszorg blijkt dat de aandacht voor kwaliteit als nuttig instrument in de concurrentiestrijd toeneemt. Op nationaal niveau zijn de laatste jaren in diverse landen kwaliteitszorg-programma's voor ondernemingen gestart. Deze programma's worden vaak door de overheid gestimuleerd. Zij zijn er mede op gericht op deze wijze de concurrentiepositie van landen te versterken.

Ook voor de ondernemingen zelf (of voor hun bedrijfstakken) is kwaliteitsverbetering een belangrijk concurrentie-instrument geworden. Het heeft immers positieve effecten op klantentrouw, marktaandeel en de winstpositie. Aan de vraagzijde eisen consumenten eveneens een steeds hogere kwaliteit. $\mathrm{Er}$ is dan ook een trend waar te nemen in de richting van het aanbieden van hogere kwaliteit door ondernemingen. Aangezien in veel gevallen van verzadigde markten sprake is, leidt dit tot intensievere concurrentie tussen ondernemingen, bijvoorbeeld op basis van kwaliteitsaspecten.

In de literatuur is er naast de grotere aandacht voor klanten, meer aandacht gekomen voor de concurrerende ondernemingen zelf. Binnen de marketing-discipline heeft dit onder andere geleid tot een aangepaste definitie van het marketing-concept, waarin voor het eerst de concurrentie wordt genoemd.

Omdat concurrerende ondernemingen meer invloed krijgen op het succes van de ondernerming, is het zinvol om de concurrentiepositie te analyseren. Daarnaast dient men in beslissingen ten aanzien van de ondernemings- of marketing-strategie op voorhand rekening te houden met mogelijke reacties van concurrenten. De oligopolie-theorie biedt hiervoor vanuit wetenschappelijk oogpunt een nuttig aanknopingspunt. Met name in de laatste jaren wordt vanuit de "industriële economie" een wetenschappelijk kader ontwikkeld waarin, veelal aan de hand van case studies, de verschillende reactiehypothesen en -strategieën empirisch worden getoetst (Oxenfeldt and Moore 1978, Porter 1979, Rothschild 1979). In die analyses wordt op voorhand rekening gehouden met concurrentiële tegenacties.

Kwaliteitsvraagstukken zijn binnen marketing sterk onderbelicht. Bij dienstenmarketing speelt de interactie tussen klant en medewerkers van de onderneming een cruciale rol. Vanwege dit specifieke karakter wordt in het kader van dienstenmarketing relatief veel aandacht besteed aan kwaliteitsvraagstukken (zie bijvoorbeeld Faes \& van Tilborgh 1984, Parasuraman, Zeithaml \& Berry 1985, Grönroos 19841986 1990, Gelderman \& Leeflang 1988, Kasper \& Lemmink 1989). In de marketing-handboeken wordt het kwaliteitsvraagstuk nauwelijks behandeld. Bij een inventarisatie van een vijfentwintigtal recente en veel gebruikte nederlands-, duits- en engelstalige marketing tekstboeken blijkt dat het onderwerp nauwelijks aandacht krijgt. Kwaliteit wordt bijvoorbeeld, behalve door 
Leeflang (1987) en Kotler (1984), in de onderzochte handboeken niet gedefinicerd. Typerend is dat bijvoorbeeld (als gunstige uitzondering) Leeflang (1987; 1A, p. 221/222), toch maar slechts 11 regels wijdt aan kwaliteitsbeleid en -beheersing. Het begrip kwalliteit wordt daarbij behandeld in het kader van de invulling van de "produkt-doelstelling" binnen de klasse van markt-instrumenter "produkt". Het wordt niet expliciet onderkend als een centraal thema in het ondernemings- en marketingbeleid.

Kwaliteitsvralagstukken, in het bijzonder de effecten van kwaliteitsverbeteringen in produkten, zijn in de economische wetenschap eveneens sterk onderbelicht. Wanneer het aantal studies ten aanzien van prijswraagstukken wordt vergeleken met het aantal dat gaat over kwaliteitsverbeteringen valt op dat de micro-economische theorieèn en theorieèn ten aanzien van marktvormen voornamelijk gaan over prijs en prijsreacties. Dit geldt ook voor studies over oligopoloide marktvormen waarin veel aandacht besteed wordt aan de reacties van concurrenten op de eigen beslissingen van de onderneming.

Een verklaring hiervoor zou kunnen zijn dat het kwaliteitsbegrip gekenmerkt wordt door een veelzijdige omschrijving en derhalve moeilijk is te definiëren. Daardoor wordt het analyseren van reactiehypothesen en resultaten in termen van winst of marktaandeel eveneens een moeilijke aangelegenheid. Een andere verklaring zou kunnen zijn dat de kwaliteit als een gegeven wordt beschowwd.

Dit globale overzicht geeft aan dat nog weinig bekend is over het expliciet concurreren via kwaliteit, veranderingen in kwaliteit van produkten en de reacties daarop van concurrenten.

\section{Probleemstelling van het onderzoek}

Omdat nog weinig onderzoek op het onderhavige terrein is verricht, wordt in ons onderzoek -waar mogelijk- aangesloten bij min of meer vergelijkbare, reeds bestaande studies. Enerzijds is wetenschappelijk onderzoek verricht naar de concurrentiele reacties op markttoetredingen. Dit onderzoek is veelal op de micro-economische theorie gebaseerd. In dergelijk onderzoek worden -meestal op basis van cross-sectie gegevenshypothesen getoetst. Anderzijds wordt getracht met behulp van marktaandeelmodellen, waarbij rekening wordt gehouden met concurrentiële reacties, een afgebakende markt te analyseren. Deze analyses worden meestal uitgevoerd met behulp van econometrische modellen. In een aantal studies wordt het marketing-mix instrument produkt(kwaliteit) gespecificeerd.

Concurrentiële reacties ten aanzien van produktkwaliteitsverbeteringen worden in beide soorten studies nawwelijks als zodanig geanalyseerd. Ons onderzoek is er op gericht om concurrentiële reacties op en het succes van produktkwaliteitsverbeteringen te analyseren. Daarbij dient rekening gehouden te worden met de aanleidingen voor produktkwaliteitsverbeteringen binnen de onderneming en externe factoren zoals marktomstandigheden. Nader geformuleerd luidt de centrale probleemstelling:

Indien ondernemingen de kwaliteit van hun produkten verbeteren, reageren de concurrenten daar dan op? Als concurrenten daadwerkelijk reageren, op welke wijze doen
zij dit dan? 
Bij een nadere beschouwing van deze probleemstelling lijkt het relevant apart aandacht te besteden aan:

* De aanleiding voor het aanbrengen van de kwaliteitsverbetering.

* De soort kwaliteitsverbetering.

* De specifieke reactie van de concurrenten.

* Het uiteindelijke resultaat van de kwaliteitsverbetering voor de onderneming die het initiatief tot een kwaliteitsverbetering heeft genomen.

Om deze probleemstelling te onderzoeken wordt enerzijds gebruik gemaakt van de literatuur over markttoetredingen en concurrentiële reacties, omdat een vergelijkbare onderzoeksopzet wordt gekozen en er een zekere verwantschap is met ons onderwerp. Anderzijds wordt gebruik gemaakt van de inzichten uit econometrisch onderzoek naar vergelijkbare vragen omdat in enkele studlies het marketing-mix instrument produkt(kwaliteit) expliciet is opgenomen.

Ons onderzoek geeft -gegeven het reeds verrichte onderzoek en de aard van de probleemstelling- vooral een beschrijving van kwaliteitsverbeteringen en de reacties van concurrenten. Het is derhalve exploratief van aard. Het onderzoek beschrijft in feite én produktkwaliteitsverbetering op én moment. Als zodanig is het dus een beschrijving van één gebeurtenis uit het doorlopende concurrentieproces van acties en reacties van ondernemingen. De beschrijving gebeurt vanuit de optiek van de onderneming die de kwaliteit van haar produkt verbetert, met het doel de concurrentie bij te houden of zich te profileren ten opzichte van de concurrentie. De reactie van concurrenten wordt eveneens vanuit de optiek van de initiërende onderneming geanalyseerd: hoe ziet de initiator de reacties van eventuele concurrenten? Deze reactie kan de inzet van een veelheid aan marketing-instrumenten betreffen, zoals prijs-, kwaliteits- of distributie-aanpassingen en reacties in de promotionele sfeer.

In dit onderzoek staat de perceptie van het management van de onderneming centraal naast de feitelijke kwaliteitsverbetering. Het ontwikkelde model wordt derhalve gekenmerkt door een "behavioural" benadering van de onderneming. In de uiteindelijke analyse staat niet de individuele onderneming en haar gedrag centraal, maar groepen ondernemingen. Omdat specifiek de groep van industriële ondernemingen met duurzame produkten wordt bestudeerd kunnen op meso-niveau conclusies worden getrokken. Op deze wijze wordt getracht ingrediënten voor een algemeen geldige theorie aan te leveren.

\section{Wetenschappelijke relevantie}

Met behulp van de hiervoor aangeduide exploratieve benaderingswijze wordt gepoogd een bijdrage te leveren aan de wetenschappelijke kennis en inzichten op dit terrein. Voor zover ons bekend wordt voor het eerst een beschrijving gegeven van het concurrentieproces dat ontstaat bij het aanbrengen van een produktkwaliteitsverbetering en waarbij expliciet de reactie van concurrenten empirisch wordt vastgesteld (Lemmink 1987). Gebaseerd op de bevindingen zou, in een vervolgonderzoek, een normatief kader opgesteld kunnen worden met mogelijke reactiehypothesen. Analoog aan reeds bestaande oligopolie-theorieën zouden dan de effecten op bijvoorbeeld winst en marktaandeel voorspeld kunnen worden. 
Hoofdstuk 1 gaat in op de context van kwaliteitsverbeteringen en concurrentie. Hoofđstuk 2 bevat een aantal uitgangspunten en definities die relevant zijn voor het onderzoek en Hoofdstuk 3 geeft een overzicht van de literatuur ten aanzien van produktkwaliteitsverbeteringen. Hoofdstuk 4 bevat de specificatie van het exploratieve model met de bijbehorende hypothesen. In hoofdstuk 5 volgt de beschrijving van de opzet van het empirische onderzoek en hoofdstuk 6 bevat de profielen van de ondernemingen die aan het onderzoek hebben deelgenomen en hun produktkwaliteitsverbeteringen. Hoofdstuk 7 gaat gedetailleerd in op de resultaten van het empirische onderzoek naar produktkwaliteitsverbeteringen in de industriële markt van duurzame produkten en de reacties van concurrenten die de managers waarnemen. Tenslotte bevat hoofdstuk 8 de mogelijke verklaringen van de resultaten en suggesties voor verder onderzoek. 


\section{De context van kwaliteitsverbeteringen en concurrentie}

Dit hoofdstuk is bedoeld om in grote lijnen aan te geven wat het probleengebied van deze dissertatie is. Binnen de marketing kunnen kwaliteitsverbeteringen opgevat worden als verbeteringen ten aanzien van het marketing-mix instrument produkt. Als zodanig is het een instrument voor ondernemingen om mee te concurreren, naast prijs, promotie en distributie. Om de plaats en functie van kwaliteitsconcurrentie binnen ondernemingen en in de maatschappij toe te lichten zal eerst het recente kwaliteitsdenken in Nederland en in het buitenland worden geschetst. Daarna wordt aandacht besteed aan het belang van kwaliteitsconcurrentie voor ondernemingen.

\subsection{Het recente kwaliteitsdenken}

Aangespoord door de nationale overheid en door middel van stimuleringsprogramma's wordt het Nederlandse bedrijfsleven de afgelopen jaren gestimuleerd om meer aandacht aan kwaliteitszorg te besteden. Het voornaamste doel is de concurrentie-positie van het Nederlandse bedrijfsleven en de B.V. Nederland in haar totaliteit te versterken. Het eerste stimulerings-programma van de overheid op dit terrein resulteerde onder meer in een "Stappenplan voor de invoering van kwaliteitszorg" (Koopman-Iwema, de la Rambelje \& Jansen 1987). Dit stappenplan bevat een praktische handleiding om stapsgewijs kwaliteitszorg in een onderneming te introduceren. Het door de overheid recent gestarte programma "Kwaliteit en logistiek" heeft tot doel de groeiende aandacht voor kwalliteit verder te stimuleren (Horning \& Pruijt 1989).

De primaire aandacht in de meeste publicaties, en ook in het genoemde stappenplan, is gericht op de interne kwaliteitszorg. Interne kwaliteitszorg geeft aanzetten voor verbeteringen gericht op de kwaliteit van het werk en de produktie(voortbrengings)processen binnen de onderneming. In de meeste projecten wordt, in het kader van bijvoorbeeld Total Quality Control, ook het belang van de "externe kwaliteitszorg" in de relatie met de klanten, via marktonderzoek, klachten en dergelijke onderschreven (zie o.a. Feigenbaum 1961, Juran, Gryna \& Bingham 1974, Crosby 1979, Mulder 1981 en Ishikawa 1985; richtlijnen weergegeven in de NEN/ISO-9000 tot en met NEN/ISO-9004 normen ${ }^{1}$ ). Vervolgens wordt echter aan deze externe kwaliteitszorg, in vergelijking met interne kwaliteitszorg, weinig aandacht besteed. In de nationale zowel als in de internationale literatuur heeft interne kwaliteitszorg veel aandlacht gekregen, terwijl externe kwaliteitszorg onderbelicht is.

In onze studie zall nu met name de externe kwaliteitszorg worden belicht vanuit verschillende optieken. Hierbij zal gebruik worden gemaakt van literatuur over kwaliteitsmanagement, van marketing-literatuur, en van micro-economische literatuur.

Aan de vraagzijde van de markt is de laatste jaren een ontwikkeling te bespeuren naar een steeds grotere vraag naar kwalitatief betere produkten. (Abrams 1981, McEachorn \& Javitz 1981, Leonard \& Sasser 1982, Whirlpool-report 1983, Takeuchi \& Quelch 1983, 
Noëlle-Neumann 1983 , Konert 1984, Berry, Zeithaml \& Parasuraman 1985, Parasuraman, Zeithaml \& Berry 1985, Absatzwirtschaft 1988). Mlustratief is in dit verband de uitspraak van Fleming $(1986 ;$ p. 1) naar aanleiding van het jaarlijkse onderzoek in de Verenigde Staten naar pregnante marketing knelpunten. De ondervraagde marketing managers signaleerden een groeiende vraag naar produkten van hogere kwaliteit:

\footnotetext{
The leading concerns of marketing executives reflect increasing competition from worldwide markets, greater price awareness on the part of the customers and an increasing demand for high quality products" *
}

Een sterke kwaliteit van het produkt en de dienstverlening (ten opzichte van de concurrentie) is van belang om aan deze "kwaliteits"-vraag tegemoet te komen. Dat een dergelijke hoge relatieve produktkwaliteit ook winstgevend is voor ondernemingen is in verschillende studies aangetoond.

Met name gaat een hoge relatieve produktkwaliteit vaak samen met hoge marktaandelen en hoge ROI's (Return on Investments). Er zijn diverse studies op basis van de PIMS ${ }^{2}$ database, die deze relaties bevestigen (Schoeffler, Buzzel \& Heany 1974, Buzzel \& Wiersema 1981, Phillips, Chang \& Buzzel 1983, Thompson, DeSouza \& Gale 1985, Luchs 1986, Buzzel \& Gale 1987, Jacobson \& Aaker 1987, Garvin 1988).

Naast deze studies geven veel auteurs op basis van case-studies en management consultancy ervaring aan dat er een sterk verband bestaat tussen het streven naar kwaliteit en de behaalde resultaten, in de vorm van marktaandelen of ROI (Reddy 1980, Leonard \& Sasser 1982, Garvin 1983 1984ab 1987 1988, Reddy \& Berger 1983, Hagan 1984, Ross \& Shetty 1985, Hooley \& Lynch 1985, Saunders \& Wong 1985, Shetty 1987). Een andere auteur, Ohmae (1982), maakt op een inzichtelijke wijze duidelijk waar het om gaat. In de strategische driehoek klanten, concurrenten en ondernemingen, is het van belang om als onderneming een goede relatie op te bouwen met de klanten. Als het aanbod van de verschillende concurrenten gelijk is en de klant dus geen onderscheid kan maken tussen twee aanbiedingen, kan er cen prijzenoorlog ontstaan (vergelijk de oligopolietheorie). Dat kan nadelig uitwerken voor de concurrentie, maar ook voor de onderneming zelf. Een betere afstemming van produkten op de klantenwensen door bijvoorbeeld kwaliteitsverbeteringen in de vorm van meer aandacht voor de relatie met de klant zorgt voor een sterkere strategische concurrentiepositie op lange termijn.

In de op wetenschappelijk onderzoek gebaseerde marketing-literatuur, werd aan produktkwaliteit, tot voor kort, ook weinig aandacht besteed. De conclusie van Phillips, Chang \& Buzzel (1983; p. 42) luidt:

\footnotetext{
"In view of the potential importance of product quality, it is surprising so little attention has been paid to it by marketing scholars. Marketing management texts generally ignore the topic and only a handful empirical studies exist".
}

Gezien de geringe hoeveelheid marketing-literatuur over kwaliteit, anders dan op basis van de PIMS-studies en analyse van afzonderlijke cases en consultancy ervaringen, is deze opmerking nog steeds actueel. 
Aandacht voor de concurrenten, naast de consumenten is een cruciaal onderdeel van de hedendaagse marketing-literatuur. Echter, concurrentie wordt al lang bestudeerd vanuit de micro-economische theorie. In deze paragraaf wordt -in verband met het thema van ons onderzoek- een beknopt overzicht gegeven van theorieën en empirische onderzoeken die met name de concurrentie met produktdifferentiatie en kwaliteit als centrale thema's, als kenobject hebben. Eerst wordt de micro-economische invalshoek gekozen, daama de marketing invalshoek.

\title{
1.2.1. Micro-economische invalshoek
}

Een definitie van "concurrentie" wordt bijvoorbeeld gegeven door Clark (1961; p. 13):

\begin{abstract}
"Competition between business units in the production and sale of goods is the effort of such units, acting independently of one another (without concerted action), each trying to make a profitable volume of sales in the face of the offers of other sellens of identical or closely similar products".
\end{abstract}

Clark geeft verder aan dat het instrumentarium dat de onderneming ter beschikking heeft om te concurreren bestaat uit:

"...the selection and design of a product, selling effort to bring it to the notice of potential customers and price" (p. 16).

Naast deze instrumenten, die reeds door Chamberlin (1946) zijn geïntroduceerd, speelt volgens Bain (1956) en Sylos-Labini (1962) de potentiéle concurrentie een rol. Ondernemers kunnen immers, gelokt door hoge winstmarges (alls gevolg van hoge prijzen) besluiten de markt te betreden. Enerzijds staat de onderneming een instrumentarium ter beschikking om de voorkeuren van de consument te beinvloeden. Anderzijds speelt ook de potentiële concurrentie mee bij de beslissing gebruik te maken van éen of meerdere instrumenten teneinde de winst te maximeren. Met name wanneer sprake is van concurrentiële reacties en strategische afhankelijkheid van ondernemingen is vanuit de oligopolietheorie een groot aantal hypothesen geformuleerd ten aanzien van prijsreacties (zie bijvoorbeeld Cournot 1927, Von Stackelberg 1952) en het anticiperen op reacties (o.a. Sylos 1962, Bain 1956, Modigliani 1958, Stigler 1966, Marris 1968, Needham 1969). Echter ten aanzien van de feitelijke aard van de reacties en (mogelijke) consequenties in termen van winst of marktaandeel is nog zeer weinig bekend (Biggadike 1979).

\subsubsection{Marketing invalshoek}

De hoeveelheid literatuur over concurrentieanalyse en -strategie is sinds het begin van de jaren tachtig sterk toegenomen (Porter 1980). In de marketing-theorie wordt in het "societal marketing concept" van Kotler (1980; p. 29) bijwoorbeeld pas aandacht aan de groep concurrenten besteed:

".... and to deliver the desired satisfactions more effectively and efficiently than competitors....".. 
In 1983 is in de definitie van de strategische marketing-conceptie (Day en Wensley 1983; p. 83) expliciet een passage over concurrentie opgenomen:

"The marketing function initiates, negotiates and manages acceptable exchange relationships with key interest groups, or constituencies in the pursuit of sustainable competitive advantages, within specific mankets, on the basis of long num consimer and channel framchises".

Deze definitie vermeldt dus dat voor een "sustainable competitive advantage" moet worden gezorgd. De uitbreiding van de definitie met deze passage geeft aan dat naast de aandacht voor de consument en de maatschappij als geheel ("long run consumer and channel franchises") binnen de marketing nu ook expliciet plaats is voor concurrentie(analyses).

Kotler (1984; p. 383) geeft de veranderingen die gezorgd hebben voor een dergelijke aanpassing van de definitie van het marketing-concept eenvoudig en kernachtig weer:

"In the fast-growth econony of the 1960-s, companies paid less attention than today to their competitors. The economic pie was growing fast enough for everyone to succeed. In the seventies and eighties, lackluster economic growth brought about intensified competition....Companies increasingly based their marketing strategies on the logic of both consumer wants and competitors" positions".

Vier jaar later (Kotler 1988; p. 234) vermeldt dezelfde auteur in de nieuwe druk van het tekstboek:

"In the Soaring Sixties, companies could ignore their competitors because most markets were growing. In the Turbulent Seventies and Flat Eighties, companies realized that sales gains would largelly come by wresting share away from competitors. As a result, today's companies are starting to pay as much attention to tracking their competitors as to understanding their target customers."...

Bij het ontwikkelen van concurrentiestrategieen is het derhalve van belang rekening te houden met de concurrentiepositie. Door bepaalde marketing-strategieën uit te voeren kan vervolgens een verschuiving in de concurrentieposities optreden. Concurrenten anticiperen nu hierop en reacties van concurrenten liggen voor de hand. Een onderneming die tracht door bijvoorbeeld een prijsdaling, produktverbetering of innovatie, een nieuwe communicatiestrategie, een markttoetreding of -uittreding haar concurrentiepositie te versterken, dient rekening te houden met en reactie van cén of meer van haar concurrenten. Deze concurrentièle reactie kan weer aanleiding zijn tot een minder sterke concurrentie-positie met een dallende winstgevendheid (zie bijvoorbeeld Daems en Douma 1984, Daems 1986). Een ondernemer moet dus niet alleen met posities van concurrenten maar ook met hun mogelijke acties en reacties rekening houden bij het formuleren en implementeren van zijn eigen strategie.

In 1985 verscheen een speciale uitgave van het Journal of Marketing, gewijd aan concurrentie en marketing. In het voorwoord van de editor, ter introductie op het thema, signaleert Weitz (1985; p. 229): 
"...., the effectiveness of marketing programs usually depends on the reaction of both customers and competitors, However, marketing theories and research have emphasized issues related to customer response and have directied less attention to competitive response. This lack of attention to competitive effects is surprising because it is difficult to imagine a marketing decision that is not affected by competitive activity",

en komt tot de slotsom dat:

"More empirical research is needed to identify the patterns of competitive response under a variety of conditions" (p. 233) $)^{3}$.

Weitz doelt in het kader van toekomstig marketing-onderzoek met name op de omstandigheden die de reactie-intensiteit en de soort reactie van de concurrent beînvloeden:

"Understanding the basis of competitive reactions is a crucial input for predicting future reactions and for incorporating more realistic reaction functions into analytical models" (p. 233).

Tot op heden heeft al enig wetenschappelijk marketing-onderzoek, gericht op concurrentiële reacties plaatsgevonden door middel van econometrisch onderzoek. De eerste econometrische exercitie, waarin expliciet de concurrentie is gemodelleerd, is al in 1969 uitgevoerd door Bass \& Parsons. Verder onderzoek op dit terrein is in 1970 gepubliceerd door Lambin. Lambin hanteerde de concurrentie als een verklarende factor in marktaandeelmodellen ${ }^{4}$, met als vooronderstelling dat voor elke concurrent de prijselasticiteit gelijk zou zijn. Een voor de hand liggende uitbreiding naar andere elementen van de marketing-mix en verschillende reactie-parameters voor de concurrenten, vindt daama plaats in het onderzoek van onder andere Wildt (1974), Lambin, Naert \& Bultez (1975), Hanssens (1980), Gatignon (1984), Leeflang \& Reuyl (1985), Alsem, Leeflang en Reuyl (1986 1989), Plat (1988), Carpenter, Cooper, Hanssens \& Midgley (1988), Leeflang \& Wittink (1990). Lambin, Naert \& Bultez (1975) bespreken diverse marktvormen en gaan bij het empirische deel van hun onderzoek uit van een oligopoloïde markt en veronderstellen bijvoorbeeld én marktleider met de overige concurrenten als volger. De andere genoemde auteurs brengen verfijningen in de econometrische modellen aan door elke concurrent apart op te nemen in het model. Een sterk punt van econometrische modellering is dat het bijvoorbeeld antwoorden kan geven op "Als .. dan?" vragen.

Enkele kenmerken van deze econometrische exercities zijn:

a) Meestal worden consumentenmarkten geanalyseerd. Industriële markten zijn zodanig complexer, dat het bijwoorbeeld al problemen teweeg brengt bij het definiëren en afbakenen van die markten.

b) Het aantal marketing-instrumenten, waarmee wordt geconcurreerd en gereageerd, dat wordt gespecificeerd, is relatief beperkt. Niet alle mogelijkheden worden doorgaans gemodelleerd. Bijvoorbeeld produktkwaliteit wordt hoogstens als een

Dit zijn econometrische modellen die het verloop van het marktaandleel trachten te verklaren. 
index opgenomen in de specificatie hetgeen geen recht doet aan het multidimensionale karakter van produktkwaliteit, wanneer dit een belangrijk concurrentie-instrument vormt op de betreffende markt.

c) In de modellen is kwaliteit het op een na belangrijkste marketing-instrument na prijs (Hanissens 1980).

d) Slechts enkele auteurs operationaliseren produktkwaliteit (Wildt 1974, Naert, Lambin \& Bultez 1975, Hanssens 1980)

e) De empirische resultaten geven slechts een afgeleid en zeer beperkt inzicht in de beweegredenen en specifieke argumenten die worden gebruikt bij: het vaststellen van de concurrentiele reactie.

Een tweede lijn van onderzoek, naast het econometrisch onderzoek, ten aanzien van concurrentie-(analyse) en concurrentiële reacties is gebaseerd op case-onderzoek. Uit het minitieus bestuderen van activiteiten van ondernemingen in een bedrijfstak ontstaat onder andere een beeld van de (potentielle) concurrentie (Porter 1980, Daems \& Douma 1984, Daems 1986). Dit type onderzoek komt in ieder geval gedeeltelijk tegemoet aan de onder a) $t / m$ e) genoemde beperkingen. Deze methodiek ontbeert echter onder andere de meetbaarheid, die juist bij econometrisch modellering inherent aanwezig is. Diverse onderzoeken uit de "industriële economie" onderzoekstraditie leveren dan ook vaak ten opzichte van elkaar tegenstrijdige aanbevelingen op (Gatignon, Anderson \& Helsen 1989).

De conclusie uit het voorgaande is dan ook dat men niet alleen met (relatieve) posities van concurrenten, maar ook met hun mogelijke acties en reacties rekening moet houden bij het formuleren en implementeren van de eigen strategie en het eigen beleid. Vanuit de micro-economie heeft de oligopolietheorie vooral bijgedragen an theorievorming op dit terrein door een aantal reactiehypothesen te postuleren. Vrijwel uitsluitend werd hierbij als instrument de prijs gehanteerd. Binnen de marketing heeft econometrische modellering reeds geleid tot een groter inzicht in de aard en intensiteit van concurrentiële reacties. Dit inzicht, dat beperkt is gebleven tot de relatief overzichtelijke consumentenmarkten, bestaat niet in de meer complexe industriële markten. Case-onderzoek in de industriële economie" traditie heeft eveneens tot beschrijvingen en aanbevelingen voor concurrentiele reacties geleid. In hoofdstuk 3 wordt hier meer aandacht aan besteed, omdat een aantal hypothesen in ons onderzoek gebaseerd zal worden op bevindingen uit dergelijke onderzoeken.

\subsection{Kwaliteit en concurrentie}

Ter afsluiting van dit hoofdstuk zal een eerste aanzet worden gegeven om tot het verband tussen de twee begrippen kwaliteit en concurrentie te komen.

Veranderingen in relatieve produktkwaliteit worden mogelijk gevolgd door reacties van concurrenten. Evenals bij prijswijzigingen kunnen concurrerende ondernemingen beschikken over de marketing-mix instrumenten om die reactie inhoud te geven. Naast het hanteren van én of meer instrumenten uit de marketing-mix, kunnen ondernemingen ook concurreren met andere zaken, zoals het intensiveren van het relatie-management, het creèren van toetredings- of uittredingsbarrières, etc..

Ons onderzoek spitst zich toe op produktkwaliteitsveranderingen en reacties met behulp van marketing-mix instrumenten. Ten aanzien van reacties van concurrenten op produkt- 
kwaliteitsverbeteringen zijn nauwelijks studies bekend. Curry en Riesz (1988; p. 46) merken op:

"....but few studies afford even geaneral guidelines for appropriate responses to quality shifts among competitors.... Results from a more complete modelling effort could be incorporated into a strategic planning paradigm that shows how a brand"s current price/quality position might be sltered over time in response to changes in positions by others in the competitive group. Currently, little empirical data exist about how competitors react to quality shifts, let alone how they should react".

Het marketing-mix instrumentarium waarmee concurrenten kunnen reageren op produktkwaliteitsverbeteringen staat centraal in dit onderzoek. Een beter inzicht in de reacties van concurrenten op produktkwaliteitsverbeteringen kan mogelijk een start zijn om preciezer aan te geven hoe gereageerd moet worden door concurrenten, gegeven de ondernemingsdoelstelling. Dat deze laatste stap complex van aard is, wordt ook aangegeven door Gatignon, Anderson en Helsen (1989; p. 45):

"Though broad guidelines have been suggested (in particular, in the industrial organization literature), they often yield conflicting predictions. Further, these guidelines come from normative models whose applicability to actual situations has not been assessed".

Om inzicht te krijgen in enerzijds de redenen voor de beslissing om de produktkwaliteit in "actual situations" te verbeteren en anderzijds de directe reactie van de concurrent(en), wordt dit onderzoek uitgevoerd. Ons onderzoek vormt derhalve een eerste aanzet voor verder onderzoek om normatieve uitspraken te kunnen doen over de aard en omvang van concurrentiële reacties op kwaliteitsverbeteringen en mogelijke consequenties voor de initiatiefnemer. Daarvoor zal in hoofdstuk 4 een model worden ontwikkeld. Eerst zal echter in het volgende hoofdstuk (hoofdstuk 2) aangegeven worden wat onder een produktkwaliteitsverbetering zal worden verstaan. In hoofdstuk 3 wordt de bestaande literatuur besproken die van nut kan zijn voor onze studie naar produktkwaliteitsverbeteringen en concurrentiële reacties. 


\section{Uitgangspunten en definities}

Dit hoofdstuk behandelt de uitgangspunten en definities bij ons onderzoek. De uitgangspunten en definities die in dit onderzoek relevant zijn, zullen worden besproken aan de hand van definities van de begrippen produkt (paragraaf 2.1.) en kwaliteit (paragraaf 2.4.). Daamaast wordt eveneens aandacht besteed aan de verschillende optieken van waaruit kwaliteit kan worden bestudeerd (paragraaf 2.2.), en aan thet kwaliteitskostenverloop bij verschillende kwaliteitsniveaus (paragraaf 2.3.). Vervolgens zal in paragraaf 2.5. kort aandacht worden besteed aan diverse methoden om kwaliteit te meten en tot slot (paragraaf 2.6.) zal een definitie worden gegeven van een produktkwaliteitsverbetering $\left(\mathrm{PKV}^{5}\right)$, zoals die in dit onderzoek zal worden gehanteerd.

\subsection{Definitie van produkt}

Leeflang (1987; p. 5-6) geeft een drietal omschrijvingen van het begrip "produkt". Deze auteur maakt onderscheid tussen het fysieke produkt, het uitgebreide produkt en het totale produkt.

Het fysieke produkt wordt omschreven als het produkt in enge zin, dat wil zeggen enerzijds als een verzameling fysieke eigenschappen die elk produkt heeft (bijvoorbeeld afmeting en gewicht) en anderzijds als een verzameling eigenschappen die specifiek zijn voor een bepaald produkt (bijvoorbeeld smaak, geur en snelheid) ${ }^{6}$.

Het uitgebreide produkt bestaat uit het fysieke produkt met een aantal toegevoegde eigenschappen, namelijk:

1. De marktinstrumenten uit de categorie "produkt" (als eén van de door de onderneming te hanteren klasse van marktinstrumenten naast prijs, verkoopbevordering en distributie), zoals verpakking, service, garantie en merknaam.

2. De overige marktinstrumenten, zoals prijs, verkoopbevordering en distributie.

Tenslotte wordt het totale produkt gedefinieerd als het uitgebreide produkt, inclusief een aantal door consumenten daarvan afgeleide eigenschappen, zoals gebruiksnut, gebruiksgemak en status.

Kotler (1984; p. 463) maakt nog onderscheid tussen het uitgebreide produkt en het tastbare produkt ("tangible product"). Het tastbare produkt is het uitgebreide produkt, zonder de hiervoor onder 2. genoemde overige marktinstrumenten.

In het vervolg van deze studie wordt, wanneer sprake is van produkt, bedoeld het tastbare produkt, inclusief de door de consument afgeleide eigenschappen. Dat is dus het fysieke produkt, plus de overige marktinstrumenten uit de categorie produkt, plus door consumenten daaruit afgeleide eigenschappen. De reden voor deze brede opvatting is dat de eigenschappen van het produkt die door de consument worden afgeleid, een belangrijke rol spelen in de kwaliteitsperceptie van het produkt (Steenkamp 1989).

In het vervolg zall het begrip produktkwaliteitsverbetering ook woorkomen als afkorting PKV. 
Daarom behoren zij in ons onderzoek betrokken te worden. De reden om niet alle overige marktinstrumenten in de definitie op te nemen, is gelegen in het feit dat het doel van onze studie gericht is op het specifiek onderzoeken van de rol van produktkwaliteitsverbeteringen. Voor zover deze overige marketing-mix instrumenten de eigenschappen van het produkt in de ogen van de consument beïnwloeden, spelen zij uiteraard wel indirect een rol. De elementen van het produkt, zoals die door Kinnear en Bernhardt (1986; p. 268) worden onderscheiden, sluiten goed aan bij de bovenstaande definitie. Deze elementen zijn:

1. Merknaam.

2. Verpakking en label.

3. Garantie.

4. Services bij aflevering, installatie en krediet.

5. Speciale, additionele eigenschappen van het produkt.

6. Fysieke attributen.

7. Veiligheid.

8. Imago en reputatie.

9. After-sales service.

10. Andere "ongrijpbare" attributen.

In onze studie zal dus het tastbare produkt, inclusief de door consumenten afgeleide eigenschappen als uitgangspunt worden gehanteerd. Het produkt, volgens deze definitie, is nader te concretiseren in de zojuist genoemde tien elementen.

\subsection{Belangrijke aspecten in de definitie van kwaliteit}

"Wat is kwaliteit?" is een vraag die in wezen moeilijk is te beantwoorden. Bijvoorbeeld Pirsig (1974) en Guaspari (1985) vinden geen eenduidig antwoord op deze vraag en vinden dan ook geen definitie. Toch wordt in de alledaagse slogans van ondernemingen de term kwaliteit gebruikt om produkten en diensten aan te prijzen. Voorbeelden van dergelijke slogans zijn: "de naam staat voor kwaliteit" en "kwaliteit is nummer 1". Kwaliteit wordt in deze slogans, maar ook in de meeste andere gevallen, gebruikt in de betekenis van "goed". De term kwaliteit stamt af van het latijnse "qualitas" dat "eigenschap", "karakter" of "hoedanigheid": betekent. Deze begrippen hebben een neutrale inhoud; er wordt geen waarde-oordeel aan de eigenschap of eigenschappen toegekend. De betekenis van kwaliteit is in de huidige gebruikelijke opvattingen minder neutraal. Van Dale (1984; p. 1496) geeft een aantal interpretaties, namelijk: deugdelijkheid, goede hoedanigheid, van beste kwaliteit. Voorbeelden zijn: "eerste kwaliteit wol", "goede kwaliteit tabak" en "kwaliteitsartikel". Als uitgangspunt voor onze studie is deze betekenis echter onvoldoende vanwege het globale karakter en onnauwkeurigheid van de
oinschrijving.

$\mathrm{Er}$ is, zoals zal blijken, een groot aantal definities van kwaliteit te geven. Dat diverse discussies gevoerd zijn over de exacte definiêring van kwaliteit heeft een aantal redenen. Zo zijn de meer-dimensionaliteit, de relativiteit en de subjectiviteit van het begrip redenen voor de moeilijkheid tot een eensluidende definitie van het begrip kwaliteit te komen (Kawlath 1969, Mulder 1976, Steenkamp, Wierenga \& Meulenberg 1985 1986). Daarnaast is kwaliteit ook een dynamisch begrip. De genoemde vier kenmerken zullen 
hieronder verder worden toegelicht.

1. Meer-dimensionaliteit.

Een produkt is opgebouwd uit verschillende, soms onderling afhankelijke produktattributen (zie bijvoorbeeld Garvin 1984b). Om een kwaliteitsoordeel van consumenten te verkrijgen, moeten deze attributen afzonderlijk beoordeeld worden en wellicht gewogen al naar gelang het belang dat men er aan hecht. Tegengesteld aan de meer-dimensionaliteit van kwaliteit is de opvatting dat "iets kwaliteit heeft of niet". Er wordt dan geen onderscheid gemaakt tussen de attributen van een produkt. Kwaliteit is een én-dimensionaal begrip in die optiek.

\section{Relativiteit.}

Het begrip kwaliteit is relatief van aard (Steenkamp, Wierenga \& Meulenberg 1986). Het is afhankelijk van de context waarin het produkt is geplaatst. Het kwaliteitsoordeel kan onder meer afhangen van de specifieke omstandigheden waarin men verkeert als men de kwaliteit beoordeelt (bijvoorbeeld kwaliteit van het voedsel voor en na het nuttigen van een maaltijd). Dit is in tegenstelling tot bijvoorbeeld het dagelijkse spraakgebruik, waar men wel opmerkingen aantreft als "dit is een kwaliteitsprodukt". Met een dergelijke opmerking wordt veelal bedoeld dat het betreffende produkt als goed of uitstekend wordt beoordeeld. Men hanteert daarbij kennelijk een bepaalde standaard waartegen de produkten worden afgezet.

\section{Subjectiviteit.}

Kwaliteit is een subjectief begrip omdat de kwaliteit van een produkt niet alleen afhankelijk is van produkteigenschappen, maar ook van behoeften van een individu. Subjectiviteit houdt in (Kawlath 1969; p. 16, zie ook Holbrook \& Corfman 1985):

\section{"...dass eine Tatsache nur im Subject begrundet ist und nur fur das Subject gultig ist",}

Een deel van de eigenschappen is vaak niet objectief meetbaar. Produkteigenschappen zijn in te delen in objectief en niet-objectief normeerbare eigenschappen. Onder objectief normeerbare eigenschappen worden die eigenschappen verstaan, die met behulp van eenduidige fysische of chemische maatstaven te meten zijn, bijvoorbeeld gewicht, snelheid, tijdsduur, samenstelling en temperatuur. De niet-objectief normeerbare produktattributen (volgens Box 1980, de psychische deelkwaliteiten) worden gevormd door die attributen, die niet met behulp van eenduidige maatstaven te meten zijn. Bijvoorbeeld: smaak, geur, prestige, schoonheid, vormgeving en status. Wimmer (1975) maakt onderscheid tussen reële kwaliteitsdimensies en ideële kwaliteitsdimensies. Onder de eerste categorie vallen de kwaliteit van het materiaal of de componenten, de bewerkingskwaliteit en de functionele kwaliteit (tijdens het gebruik). De ideële kwaliteit bestaat uit de esthetische kwaliteit (vormgeving en smaak) en ethische kwaliteit. Slechts reële kwaliteitsdimensies zijn normaliter meetbaar en kwantificeerbaar volgens Wimmer.

Tegengesteld aan deze visies kan een visie gehuldigd worden die uitgaat van het feit dat er "kwaliteitsprodukten" bestaan, die door iedereen als zodanig herkend worden. Dat betekent dus dat kwaliteit een objectief meetbare grootheid is. 


\section{Dynamiek.}

Kwaliteit is ook een dynamisch begrip. De dynamiek vloeit voort uit het feit dat de behoeften van consumenten regelmatig aan veranderingen onderhevig zijn. Daarbij kan bijvoorbeeld verwezen worden naar de veranderende voorkeur van de consument in enkele jaren tijd ten gunste van kwalitatief betere produkten ten koste van produkten met een mindere kwaliteit. Een andere indicatie wordt gegeven door de testen van de Consumentenbond in Nederland, waarin verschuivingen te zien zijn ten aanzien van het belang van de verschillende factoren waarmee produkten worden beoordeeld (zie ook Takeuchi \& Quelch 1983; p. 142).

Deze trends kunnen voortkomen uit stijgende aspiratieniveaus van consumenten bijvoorbeeld door de ontwikkeling van de welvaart en ervaringen uit het verleden. Tegenover de dynamische visie staat de statische visie dat kwaliteit onafhankelijk van de tijd; door iedereen herkenbaar is.

De visie dat in principe kwaliteit een eéndimensionaal begrip is, bovendien als een blijvende standaard kan worden aangemerkt en als zodanig onafhankelijk van de tijd door iedereen herkenbaar is, kan worden gekenschetst als het metafysische kwaliteitsbegrip (Pirsig 1974, Tuchman 1980, Guaspari 1985). Dit kwaliteitsbegrip is niet operationaliseerbaar in onderzoek omdat het niet objectief meetbaar is. Derhalve dient voor elk onderzoek bij de definiëring van kwaliteit met de genoemde vier factoren rekening gehouden te worden. Garvin (1984b) onderscheidt vijf invalshoeken van waaruit kwaliteit kan worden bestudeerd en in het verleden is bestudeerd. Elke invalshoek bevat een visie van waaruit, gegeven de gesignaleerde problemen met de definitie, een poging wordt gedaan om kwaliteitsvraagstukken te analyseren. We zullen ze in de volgende paragraaf kort bespreken.

\subsubsection{Vijf optieken voor het bestuderen van kwaliteit}

Garvin (1984b) onderscheidt vijf verschillende invalshoeken van waaruit de kwaliteit gedefinieerd en bestudeerd kan worden, namelijk:

a. De metafysische benadering.

b. De produktiegerichte benadering.

c. De gebruikersgerichte benadering.

d. De produktgerichte benadering.

e. De waardegerichte benadering.

Voorbeelden van definities die vallen onder de laatstgenoemde, waardegerichte benadering zijn: "Quality is the degree of excellence at an acceptable price and the control of variability at an
acceptable cost" (Broh 1982; p. 3), en

"Quality means best for certain customer conditions. These conditions are (a) the actual use and (b) the selling price of the product" (Feigenbaum 1961; p. 1).

Aan deze waardegerichte benadering wordt in deze beschouwing verder geen aandacht besteed omdat de prijs geen expliciet onderdeel uitmaakt van onze definiëring van het 
begrip produkt. Het waardeconcept kan gezien worden als het resultaat van de samenvoeging van prijs- en kwaliteits-aspecten?. Achtereenvolgens zullen de eerste vier (a $\mathrm{t} / \mathrm{m}$ d) benaderingen worden besproken.

Volgens deze benadering is kwaliteit synoniem met "innate excellence" (Garvin 1984b; p.41), de altijd herkenbare uitmuntendheid. Het begrip kan echter niet precies worden gedefinieerd. Vandaar dat kwaliteit wordt omschreven als iets metafysisch. Pirsig (1974; p. 185) komt tot de conclusie:

"....even though Quality cannot be defined, you know what it is".

Men kan kwaliteit niet definiëren, maar men weet wel wat het is (zie ook Tuchman 1980 en Guaspari 1985 voor vergelijkbare omschrijvingen). Deze benadering komt, vanwege het ontbreken van een precieze definitie, niet voor in de wetenschappelijke (bedrijfs)economische literatuur.

b) De produktiegerichte benadering.

In deze benadering wordt de nadruk gelegd op het overeenkomen van de kenmerken van het produkt met de specificaties. De definitie van kwaliteit van Crosby $(1979 ;$ p. 15$)$ is:

"....conformance to requirements".

Hoe beter het produkt aansluit bij de specificaties, hoe hoger de kwaliteit. Kwaliteit is dus een meetbaar concept door normen vast te stellen voor technische specificaties van een produkt. Het produktieproces en de verbeteringen en aanpassingen hierin om aan de specificaties te voldoen, staan centraal in deze benadering.

De technische specificaties voor produkten worden geformuleerd, nadat bijvoorbeeld behoeften, doelen of verwachtingen van de consument zijn geïnventariseerd. Daarbij dienen de specificaties een zo goed mogelijke vertaling van deze behoeften, doelen of verwachtingen te zijn. Aangezien dit geen continu-proces hoeft te zijn, is dus niet zonder meer zeker of bij "conformance to requirements" ook daadwerkelijk op elk willekeurig moment kwaliteit wordt geleverd, in de zin van aansluiting op behoeften van de klant. Afgezien daarvan, wordt bij deze benadering in de praktijk het zwaartepunt gelegd bij de specificaties. Dit is een fundamenteel andere, intern gerichte, visie dan een visie waarbij werkelijk de klant centraal wordt gesteld.

In de literatuur wordt bij "conformance to requirements" wel gesproken van uitvoerings(fabricage-)kwaliteit en bij het laten aansluiten op de klantenwensen van ontwerpkwalliteit. Naast de uitvoeringskwaliteit en ontwerpkwaliteit onderscheiden Juran \& Gryna (1970) en Juran, Gryna \& Bingham (1974) verzekerde diensten van het produkt naar de gebruiker 
toe en de after-sales service voor klanten als andere aspecten van kwaliteit. De belangrijkste factoren hierbij zijn de betrouwbaarheid en de onderhoudsvriendelijkheid. After-sales service is van belang wanneer de prestaties van de apparatuur achterblijven of preventief onderhoud vergen. In het geval dat de prestaties van het produkt achterblijven, is snelheid van service en deskundigheid van handelen opportum (Juran, Gryna \& Bingham 1974, Takeuchi \& Quelch 1983).

Het handhaven van een zeker kwaliteitsniweau van een produkt gaat gepaard met kosten (kwaliteitskosten). In de "traditionele" benadering van kwaliteitszorg (Garret \& Silver 1973, Feigenbaum 1983) komt men tot de conclusie dat een optimaal kwaliteitsniveau bestaat. Deze optimale kwaliteit wordt bereikt wanneer de kosten van het voorkomen van defecten groter worden dan de kosten van de gevolgen van deze defecten. Deze benadering wordt niet onderschreven in een aantal recentere opvattingen (Takeuchi \& Quelch 1983, Ross \& Shetty 1985). Omdat verlies van goodwill en toekomstige verkopen een veel belangrijker kostenpost vormen dan in de traditionele benadering wordt verondersteld, is er geen optimaal kwaliteitsniveau, volgens die redenering. Men is beter af door te streven naar "zero defects".

\section{c) De gebruilkersgerichte benadering.}

In deze benadering wordt kwaliteit beschouwd als subjectief en aan verandering onderhevig. Bij de definities ligt het accent op de door klanten gepercipieerde kwaliteit. Garvin (1984b) geeft de omschrijving:

".... quality "lies in the eyes of the betholder" .

Omdat de klant uiteindelijk de beslissing neemt het produkt wel of niet te kopen, is het van belang kwaliteit te definiëren vanuit de klant. De bekendste definitie is die van Juran (1974; p. 2.2) waarbij het gebruik door de klant centraal wordt gesteld:

"Quality is fitness for use"..

d) De produktgerichte benadering ${ }^{8}$.

In deze benadering wordt kwaliteit beschouwd als een eenduidige en meetbare variabele. Verschillen in kwaliteit hangen direct samen met verschillende hoeveelheden ingrediënten of attributen, aanwezig in het produkt (Abbott 1955, Leffler 1982). Deze benadering heeft voornamelijk een micro-economische invalshoek.

Lange tijd zijn kwaliteitsaspecten door de economische theorie niet behandeld omdat, zoals Abbott (1955; p. 9) het stell: 
The core of theoretical economics has been, from the time of Ricardo and coumot up to the present Keynesian age, the theory of competitive markets; and the kind of competition envisaged in this theory has been the kind that occurs in the great produce mankets, where masyy buyers and sellers dicker over the terms of sale of quantities of some homogeneous or standardized commodity whose quality is never called into question".

De eerste aanzetten in de richting van analyses van produktkwaliteit stammen uit de eerste helft van deze eeuw. In de dertiger jaren werd het duidelijk dat de belangrijkste in de praktijk voorkomende marktvormen niet volledige mededinging of monopolie waren, maar monopolistische concurrentie en oligopolie. Binnen deze marktvormen is plaats voor gedifferentieerde produkten (Robinson 1933, Chamberlin 1946). Een andere observatie was dat prijsconcurrentie door ondernemingen werd vermeden, en dat in toenemende mate gebruik werd gemaakt van "niet-prijs"-instrumenten zoals produktkwaliteit". "Niet-prijs"instrumenten zijn waarschijnlijk de belangrijkste concurrentiewapens in de huidige oligopoloüde markten (Koutsoyiannis 1982). Concurrentie-instrumenten die worden genoemd zijn produkt, prijs, hoeveelheid en verkoopinspanning. Het is veelvuldig aangetoond dat deze vier instrument-wariabelen tegelijk worden gehanteerd in een mixtuur die door de onderneming optimaal wordt geacht: De relaties tussen deze instrumenten kunnen in een stelsel van simultane vergelijkingen worden uitgedrukt, waarbij in de functie van de afzet en de afzonderlijke instrumenten naast de andere instrumenten ook nog plaats is voor overige determinanten. Bijvoorbeeld voor de bepaling van het produktbeleid is plaats voor een indicator van het soort produkt (duurzaam/ niet

Zie ook Koutsoyiannis (1982; p. 2-4), die twalftal redenen geeft voor de voorkeur van oligopolistische ondernemingen voor concurrentie op basis van "non-price". Dit zijn:

"(1) Price cuts can be matched immediately by rivals and may lead to nuinous price wars, while product imitations take time.....

(2) Technological progress has been spectacular over the last thirty years, and has resullted in greatly improved products, as well as completely new products, materials and methods of production....

(3) Tastes of consumers have been changing fast as result of economic growth and increasing incomes....

(4) Firms have become increasingly aware of their power to influence the tastes and demands of buyers, by prowiding information about new product varieties through advertising and other selling actiwities....

(5) Price reductions are disliked because they bring pressure for detoriation of the quality standards of the product....

(6) Firms have leamed that a lag nesponse to customers" demands or to competitors' product and selling strategies may have serious effects on their mariket shares....

(7) While price changes are immediately obvious, product changes may not be easily detected by buyers....

(8) In markets where buyers have developed the attitude of judging quality by price, firms avoid price cuts, even when cost considerations make such reductions possible $e_{\text {.... }}$

(9) Similarly, in markets where "customary" retail price classes have developed, firms feell it necessary to preserve this price structure, adjusting their product to the "price classeds" when cost conditions change.

(10) Firms often use product changes as a way of absorbing increasing costs in order to avoid increases in price....

(11) Firms hawe found that product changes are in many cases an effective method for raising prices....

(12) Firms have found that product differences make price discrimination more effective in the various segments of the market which have different elasticities. ". 
duurzaam), een reactie van de concurrentie of een schaalvoordeel, naast de instrumenten prijs, hoeveelheid en verkoopinspanning. Needham (1969) maakte duidelijk dat een algemeen-evenwicht benadering noodzakelijk zou zijn om simultaan de optimale mix van instrumenten te bepalen. In het vervolg zullen wij zowel in de komende analyses als in het empirische onderzoek niet uitgaan van deze simultane maar van een partiële benadering, omdat, zoals Koutsoyiannis (1982; p. 6 ) het uitdrukt:

This approach has merits not only as a method of analysis of complex behaviour but it is also relewant to real life sitwations in which firms attempt to reach the optimum pollicy-mix gradually, by concentrating on one or a few aspects of policy at any one time.".

Ter afsluiting blijkt dat de onder de benaderingen a) tot en met d) genoemde literaturur een tweetal, voor onze studie relevante aanknopingspunten, biedt. Zo is het zinvol onderscheid te maken tussen de verschillende benaderingen: produktie, produkt en gebruiker. Verder is het zinvol een partiële benadering te kiezen.

In de volgende paragraaf (2.2.2) wordt de theorie die valt onder de produktgerichte benadering (d) verduidelijkt. In paragraaf 2.2.3. volgen tenslotte de conclusies ten aanzien van de bruikbaarheid van de theorieën uit de diverse benaderingen voor onze studie.

\subsubsection{Een nadere beschouwing van de produktgerichte benadering}

De produktkwaliteit als concurrentie-instrument in de micro-economische theorie zal hierna worden besproken vanuit de aanbodzijde (I) en de vraagzijde (II) van de markt. De bevindingen in deze micro-economische studies zijn van belang voor ons onderzoek naar kwaliteitsverbeteringen en concurrentiële reacties.

\section{Produktkwaliteit als instrument aan de aanbodzijde van de markt.}

In de neoklassieke economische literatuur ${ }^{10}$ wordt er in de eenvoudige modellen (Genth 1981, Mickwitz 1966, Archibald 1964, Dorfman \& Steiner 1954) vanuit gegaan dlat naast de prijs, de kwaliteit van invloed is op de gevraagde hoeveelheid. In modelvorm:

$$
\begin{aligned}
& p=p(x, Q) \text {, met } \delta p / \delta x<0 \text { en } \delta p / \delta Q>0 \\
& \text { of } \\
& \mathrm{x}=\mathrm{x}(\mathrm{p}, \mathrm{Q}) \text {, met } \delta \mathrm{x} / \delta \mathrm{p}<0 \text { en } \delta \mathrm{x} / 8 \mathrm{Q}>0 \\
& \text { Waarbij } \mathrm{x}=\text { gevraagde hoeveelheid, } \\
& Q=\text { kwaliteit.t. } \\
& \mathbf{p}=\text { prijs van thet produkt }
\end{aligned}
$$

De vraag is hoger, naarmate de kwaliteit beter is. Als $Q^{2}$ een hogere kwaliteit voorstelt dan $Q^{\sharp}$ wordt, bij een gegeven prijs, meer van het goed gevraagd bij een kwaliteitsniveau van $Q^{2}$ dan bij een kwaliteitsniveau van $Q^{1}$. Ondememingen die naar maximale winst streven hebben een winstfunctie, die afhankelijk is van de prijs en het kwaliteitsniveau. 
De winstfunctie $W(p, Q)$ is gedefinieerd als verschil tussen omzet, $O(p, Q)$ en kosten, $\mathbf{K}(\mathbf{x}, \mathbf{Q})$ :

$$
\begin{aligned}
& W(\mathrm{p}, \mathrm{Q})=\mathrm{O}(\mathrm{p}, \mathrm{Q})-\mathrm{K}(\mathrm{x}, \mathrm{Q}) \\
& \mathrm{O}(\mathrm{p}, \mathrm{Q}) \text { is gedefinieerd door } \\
& \mathrm{O}(\mathrm{p}, \mathrm{Q})=\mathrm{x}(\mathrm{p}, \mathrm{Q}) * \mathrm{p} \quad \delta \mathrm{O} / \delta \mathrm{p}=0, \delta \mathrm{O} / \delta \mathrm{Q}>0 \\
& \mathrm{Voor} \mathrm{K}(\mathrm{x}, \mathrm{Q}) \text { geldt, met } \mathrm{x}=\mathrm{x}(\mathrm{p}, \mathrm{Q}) \\
& \delta \mathrm{K} / \delta \mathrm{p}<0, \text { omdat } \delta \mathrm{x} / \delta \mathrm{p}<0 \text { en } \delta \mathrm{K} / \delta \mathrm{x}>0, \\
& \delta \mathrm{K} / \delta \mathrm{Q}>0, \text { ondat } \delta \mathrm{x} / \delta \mathrm{Q}>0 \text { en } \delta \mathrm{K} / \delta \mathrm{x}>0 \text { en bovendien } \delta \mathrm{K} / \delta \mathrm{Q}>0 .
\end{aligned}
$$

Het optimale prijs- en kwaliteitsniveau bij het streven naar winstmaximalisatie wordt bereikt als de marginale opbrengst van elk van de instrumenten gelijk is aan de marginale kosten:

$$
\begin{aligned}
& \delta \mathrm{O} / \delta \mathrm{p}=\delta \mathrm{K} / \delta \mathrm{p} \text { en } \\
& \delta \mathrm{O} / \delta \mathrm{Q}=\delta \mathrm{K} / \delta \mathrm{Q}
\end{aligned}
$$

In de micro-economische theorie is sinds de studies van Abbott $(1953,1955)$ door een aantal auteurs aandacht besteed aan kwaliteit als concurrentiewapen van de onderneming. Derhalve zullen enkele benaderingen worden toegelicht. Met name wordt aandacht besteed aan het werk van Abbott zelf $(1953,1955)$ en Brems $(1966 \mathrm{~b})$. In het werk van Abbott wordt namelijk onderscheid gemaakt tussen verschillende soorten kwaliteitsconcurrentie. In het werk van Brems komt heel duidelijk het vraagstuk van de multidimensionaliteit van het kwaliteitsbegrip naar voren. Deze benaderingswijzen achten wij ook van belang voor ons empirisch onderzoek.

Abbott (1955) maakt onderscheid tussen zuivere prijsconcurrentie en zuivere kwaliteitsconcurrentie. De marktomstandigheden waarbij de prijs van de concurrerende goederen uniform is en vaststaat, en waarbij de concurrentie gebaseerd is op kwaliteit, wordt een zuivere kwaliteitsconcurrentie genoemd. Deze marktvorm is in de praktijk moeilijk te analyseren omdat kwaliteitsconcurrentie diverse vormen kan aannemen. Abbott (1955; p. 4) analyseert twee soorten kwaliteitsconcurrentie, namelijk gebaseerd op kwaliteitsverschillen tussen produkten ("produktdifferentiatie", "produkt heterogeniteit" en bestaande "imperfecte substituten") of gebaseerd op kwalitatieve verbeteringen in produkten ("produkt variatie", "nieuwe produkten" en "nieuwe modellen").

Het uitgangspunt voor de analyses is de éndimensionale kwaliteit, gedefinieerd als een hoeveelheid ingrediënten of attributen (Abbott 1955; p. 126):

".... differences in quality often consist of differences in quantity of some desired ingredient or attribute.".

Echter:

".....not all quality differences can be described to everyone's satisfaction in such terms. In some matters of quality there is no clear-cut agreement; different people will rank qualities in different orders." (p. 127). 
Op basis van deze waamemingen komt Abbott tot het onderscheid tussen horizontale, verticale en innowatieve kwaliteitsveranderingen.

Horizontale kwaliteitsveranderingen hebben te maken met kwaliteitsattributen, die geen relatie vertonen met de kosten. De attributen worden door de verschillende groepen kopers verschillend beoordeeld. Dat is de reden warom slechts gesproken kan worden van "passender" of "aansprekender", refererend aan een groep kopers. De voorbeelden die Koutsoyiannis (1982) noemt zijn: grammofoonplaten (in dezelfde kwaliteitsklasse, maar met verschillende soorten muziek) en schoenen (in dezelfde kwaliteitsklasse, maar met verschillen in hoogte van de hak).

Het model van Abbot voor horizontale kwaliteitsconcurrentie geeft weer op welke wijze ondernemingen tot een evenwicht komen door de produktvariêteit aan te passen binnen een verticale kwaliteitsklasse bij een gegeven marktprijs. Daarbij wordt verondersteld dat de mogelijke variéteiten langs een enkelle dimensie gerangschikt kunnen worden. Bijwoorbeeld, dassen kunnen worden gerangschikt naar kleurnuance. De preferenties van de kopers zijn gelijkelijk verdeeld over de horizontale kwaliteitsschaal. Elke koper koopt die wariêteit die het dichtst bij de door hem/haar gewenste ideale variëteit ligt. Het aantal gekochte eenheden neemt af naarmate het verschil tussen de aangeboden variëteit en de ideale varieteit groter wordt. Wanneer er nu concurrenten aanwezig zijn en de ondernemingen streven naar maximale winst, dan wordt op korte termijn een evenwicht bereikt, wanneer de variëteiten op gelijke afstand van elkaar liggen. Alle ondernemingen hebben dan gelijke marktaandelen. Wanneer ondernemingen winst maken (waarbij de prijs $>$ gemiddelde totale kosten) dan zullen concurrenten toetreden tot de markt tot het punt bereikt is waarbij de prijs gelijk is aan de gemiddelde totale kosten. Op lange termijn wordt dan weer een evenwicht bereikt, met voor elke onderneming hetzelfde marktaandeel en waarbij de produkten op gelijke afstand van elkaar liggen.

In het geval ondernemingen trachten een hoog marktaandeel te verwerven door kleine concurrenten te elimineren, in plaats van het maximeren van de winst, kan het model van horizontale kwaliteitsconcurrentie aangepast worden. De kleine concurrenten worden dan geëlimineerd door frequente produktveranderingen, die de "minimum optimal scale of production" verhogen. Het resultaat is dat op een bepaald punt de concurrenten hun variabele kosten niet meer goed kunnen maken (bij cen gegeven marktprijs). Een voorbeeld zijn de jaarlijkse veranderingen in typen automobielen in de Verenigde Staten door de "Big Three" (General Motors, Ford, Chrysler) die tot gevolg hebben gehad dat kleinere concurrenten zijn verdwenen (Menge 1962).

Verticale kwaliteitsveranderingen hebben te maken met de verschillende klassen van kwaliteit. Twee kenmerken van verticale kwaliteitsveranderingen zijn:

1) Van twee produkten met verschillende kwaliteit wordt het produkt met de betere kwaliteit door alle kopers gekocht.

2) Betere kwaliteit gaat gepaard met hogere kosten.

Een verticale kwaliteitsverandering kan goed worden beschreven door de adjectieven "hoger" en "lager". Voorbeelden zijn", het octaangehalte in benzine en branduren van een gloeilamp (Koutsoyiannis 1982).

Het model voor de verticale kwaliteitsconcurrentie veronderstelt dat het evenwicht met 
betrekking tot de horizontale kwaliteitsvarièteit reeds is bereikt (Abbott 1955). De prijs is gegeven, en varieert niet tussen de kwaliteitsklassen. Verder is differentiatie in verticale kwaliteit beperkt tot én dimensie. De vraag is een toenemende functie van de kwaliteit (gegeven een vaste marktprijs). De onderneming tracht nu de winst te maximaliseren door een kwaliteitsklasse te kiezen, gegeven de marktprijs.

De conclusie is dat op korte termijn alle ondernemingen hetzelfde marktaandeel hebben en dezelfde kwaliteitsklasse aanbieden, maar wel met verschillende horizontale variëteiten. Door de winsten worden nieuwe concurrenten aangetrokken, totdat op lange termijn een evenwicht ontstaat. Wanneer de omvang van de markt constant blijft of in ieder geval niet proportioneel stijgt met de toetreding van nieuwe concurrenten, dan leidt verticale kwaliteitsconcurrentie tot een verlaging van de afzet wan elke onderneming en zo tot ongebruikte schaalvoordelen.

Wanneer ondernemingen naar afzetmaximalisatie streven in plaats van naar winstmaximalisatie wordt een evenwicht bereikt door een kwaliteitsklasse te produceren die hoger is dan die onder winstmaximalisatie, omdat afzetmaximalisatie alleen kan worden bereikt door het verbeteren van de kwaliteitsklasse. De afzet is nu hoger en de winst lager.

Wanneer ondernemingen tijdelijke verliezen kunnen accepteren, is het voor de ondernemingen mogelijk op een agressieve wijze de afzet te maximaliseren door evenzo agressieve kwaliteitsverbeteringen. Financieel zwakkere ondernemingen worden op deze wijze van de markt verdreven. Op lange termijn is het aantal concurrenten kleiner en wordt een grotere afzet bereikt per onderneming met een hogere kwaliteit. Er worden echter minder variëteiten aangeboden. De kopers moeten kiezen uit minder variëteiten van een hogere kwaliteit.

Innovatieve kwaliteitsveranderingen behelsen de introductie van een nieuwe kwaliteit, die door de meeste of alle kopers als superieur aan de bestaande kwaliteitsklassen wordt gezien. Deze innovatieve veranderingen kunnen wel of niet gepaard gaan met hogere kosten, en hogere prijzen.

Abbott (1953 1955) stelt vast dat in werkelijkheid kwaliteitsveranderingen vaak een combinatie zijn van de drie genoemde typen. Vanwege de enorme analytische problemen bij het onderzoek naar dergelijke kwaliteitsveranderingen heeft men zich in het wetenschappelijk onderzoek gericht op steeds eén van de drie typen kwaliteitsveranderingen en zijn ze niet gezamenlijk onderzocht (Koutsoyiannis 1982).

In veel micro-economische modellen wordt de afzet verklaard uit de prijs en éen of meer niet-prijs variabelen. Daarbij worden meestal de kwaliteit en de verkoopinspanning gekozen als "niet-prijs"' variabelen (zie ook Chamberlin 1953 en Clark 1961).

Een belangrijke beperking in veel micro-economische modellen (Von Stackelberg 1952, Abbott 1953, Dorfman en Steiner 1954, Archibald 1964) is dat voor kwaliteit en verkoopinspanning éndimensionale grootheden gekozen worden. Dat kwaliteit in feite geen éndimensionaal concept is, wordt door veel auteurs bevestigd (bijvoorbeeld wederom Chamberlin 1953), maar in de theorievorming wordt zelden deze multidimensionaliteit expliciet uitgewerkt.

Eén van de weinige artikelen waarin dit wel gebeurt, is van de hand van Brems (1966b). Brems werkte expliciet een model uit met een multidimensionele kwaliteitsvariabele. Volgens hem is de beslissingssituatie in werkelijkheid dat: 
"Somewhere in the firm, a decision maker must know exactly how far to go in each particular dimension of quality and selling effort (p. 160).

Hij beschouwt kwaliteit (evenals overigens de verkoopinspanning) als een multidimensioneel concept. Vervolgens wordt de input-output benadering van Leontief gehanteerd. Brems gaat uit van $a_{i j}\left(a_{i j}=\right.$ aantal inputeenheden vanuit $i$, per eenheid output van j) die de kwaliteit en verkoopinspanning volledig beschrijven. Door nu a te manipuleren (dus door aspect(en) van kwaliteit en verkoopinspanning te veranderen) kan het effect worden nagegaan op de afzet. De conclusie yan Brems is dat een ewenwichtssituatie wordt bereikt, wanneer de kwaliteit en de verkoopinspanning in elk van de dimensies worden verbeterd/verhoogd, totdat de prijs van een marginale input en de marginale "produktiviteit" van de betreffende input dezelfde is voor alle inputs.

II. Produktkwaliteit, gezien vanuit de vraagzijde van markt,

Het eerste micro-economische model dat het keuzegedrag van consumenten verklaart, en waarin kwaliteit als een verklarende factor in de preferentiefunctie is opgenomen, is ontwikkeld door Theil (1952) en Houthakker (1952). Zowell de consumptie als de kwaliteit worden als verklarende factoren opgevoerd. De individuele nutsfunctie luidt:

$$
\mathrm{U}=\mathrm{U}\left(\mathbf{x}_{1}, \ldots, \mathbf{x}_{\mathrm{n},}, \mathbf{Q}_{1}, \ldots, \mathbf{Q}_{\mathrm{n}}\right),
$$

en geeft aan dat het nutsniveau van een individu bepaald wordt door de hoeveelheden van de goederen $\mathrm{X}_{1}, \ldots \ldots, \mathrm{X}_{\mathrm{n}}$ en de kwaliteitskenmerken:

$$
\begin{aligned}
& Q_{1}=\left(Q_{11}, \ldots, Q_{1 \operatorname{ma}(1)}\right) \\
& \dot{Q}_{n}=\left(Q_{n 1}, \ldots, Q_{\text {mm(n) }}\right) .
\end{aligned}
$$

De budgetrestrictie van het individu is gegeven en luidt:

$$
\begin{aligned}
& \sum_{k=1}^{n}{ }_{x_{k} * p_{k}} \leq Y, \text { waarbij } \\
& P_{k}=p_{k}\left(Q_{k}\right) \text {, met } \delta p_{k} / \delta Q_{k}=0, \text { voor } k=1, \ldots, n \text {. }
\end{aligned}
$$

De prijs hangt dus af van het kwaliteitsniveau van de kwaliteitskenmerken. Bij de relatie tussen hoeveelheid goederen en het nut moet bedacht worden dat in het algemeen het nut toeneemt als de geconsumeerde hoeveelheid van een goed toeneemt:

$$
\delta \mathrm{U} / \delta \mathrm{x}_{\mathrm{k}}>0 \text {, voor } \mathrm{k}=1, \ldots, \mathrm{n} \text {. }
$$

In het geval van verbetering van kwaliteitskenmerken $\left(\delta \mathrm{U} / \delta \mathbf{Q}_{\mathrm{W}}\right)$, is geen eenduidige uitspraak mogelijk ten aanzien van de verandering in nut. Immers, een bepaalde eigenschap hoeft geen invloed te hebben op het nutsniveau. Ook kan er sprake zijn van een kritisch kwaliteitsniveau, waarboven of waaronder het nutsniveau weer daalt of gtijgt. 
De kosten voor het individu zijn als volgt gedefinieerd:

$$
\mathrm{K}_{\mathrm{k}}\left(\mathrm{x}_{\mathbf{s}}, \mathbf{Q}_{\mathrm{k}}\right)=\mathbf{x}_{\mathbf{k}}{ }^{*} \mathbf{p}_{\mathbf{k}}(\mathbf{Q})
$$

Bij maximering van $\mathrm{U}$ onder nevenvoorwaarden [2.7] on [2.8] wordt maximaal nut bereikt wanneer de verhouding tussen het marginale nut van de geconsumeerde hoeveelheid en kwaliteit van de goederen gelijk is aan de verhouding tussen de marginale kosten van de hoeveelheid en kwaliteitskenmerken van de goederen.

Met andere woorden, maximaal nut wordt bereikt wanneer ${ }^{11}$ :

$$
\begin{aligned}
& \frac{\delta U / \delta \mathrm{x}_{\mathrm{k}}}{\delta \mathrm{U} / \delta \mathrm{Q}_{\mathrm{k}}}=\frac{\delta \mathrm{K}_{\mathrm{k}} / \delta \mathrm{x}_{\mathrm{k}}}{\delta \mathrm{K}_{\mathrm{k}} / \delta \mathrm{Q}_{\mathrm{kj}}} \\
& \text { voor } \mathrm{k}=1, \ldots, \mathrm{n}_{;} \mathrm{j}=1, \ldots \ldots, \mathrm{m}(\mathrm{k}) .
\end{aligned}
$$

Een andere benadering, gebaseerd op de theorie van Lancaster (1966) gaat uit van kenmerken van goederen voor de bepaling van het nut. De hoeveelheden van de goederen komen niet expliciet in de nutsfunctie voor. In de marketing-literatuur wordt de Lancaster-benadering omschreven als een "bundle of satisfactions" (Lancaster 1971, Meulenberg 1971, Levitt 1980 1983). Lancaster (1971; p. 20) huldigt het standpunt dat goederen geen waarde van zichzelf hebben, maar vanwege het nut van de diverse eigenschappen van dat goed en merkt op:

"The interest of consumers is in characteristics, not in goods per se. Thus the individual consumer has preferences, in the first instance, over the set of characteristics collections. ".

Een beperking is dat de kenmerken worden gedefinieerd als:

"...those objectively measurable, technical properties of goods that are relevant to consumer choice" (pp. 114-115).

Met de Lancaster-benadering vergelijkbare studies, maar met voornamelijk een empirische achtergrond, vormen onderzoeken naar de zogenaamde hedonistische prijsfuncties (Griliches 1971). Door middel van multiple regressie worden met deze functies prijsindexen verklaard uit kwaliteit. Hierbij is kwaliteit gedefinieerd als een vector van objectief meetbare kenmerken van een gegeven merk. De regressie-coëfficiënten geven de marginale waarden aan die door de consument worden toegekend aan elk kwaliteitskenmerk. Het uitgangspunt van dergelijke exercities is het verklaren van de prijsverandering (de "pure price change") gecorrigeerd voor kwaliteitsverschillen. Daarvoor moeten de relevante kenmerken worden bepaald alsmede de functionele vorm van de relatie tussen de kenmerken en de prijzen. Voorbeelden van produkten waarvoor hedonistische prijsfuncties zijn geschat, zijn auto's (Dhrymes 1967, Griliches 1971, Cagan 1971) en tractoren (Fettig 1963).

11

Het aantal evenwichtsvoorwaarden bedragt hierbij: $n+1+\sum_{k=1}^{n}$ (k). 
Op basis van de genoemde literatur van de produktgerichte benadering kunnen we nu komen tot een aantal afslluitende conclusies.

Ten aanzien van de aanbodzijde van de markt blijkt dat de veronderstellingen bij de genoemde modellen vaak niet conform de werkelijkheid zijn. Ondanks de analytische kracht van dergelijke modellen zijn ze minder bruikbaar voor ons onderzoek. Zo gaat Abbott in feite uit van een éndimensionaliteit van de kwaliteit en speelt door de partiêle benadering slechts de kwaliteit een rol in het concurrentieproces, en niet bijvoorbeeld de verkoopinspanning. Brems gaat wit van een vaste verhouding tussen hoeveelheden input en output. Verder zien beide auteurs af van het verwachte en werkelijke gedrag van concurrenten. Koutsoyiannis (1982; p. 50) komt dan ook tot de conclusie dat:

"It should be evident ..... that much work has to be done before we can draw any definite conclusion regarding the effects of product variations on market conduct and performance".

In ons onderzoek hopen we meer zicht op deze concurrentielle reacties te krijgen. Het onderscheid dat Abbott maakt tussen horizontale, verticale en innovatieve kwaliteitsveranderingen is in dit kader zinvol, vanwege de verschillende consequenties die dat kan hebben voor bijvoorbeeld het marktaandeel of de resultaten.

Het is duidelijk dat analyses aan de vraagzijde van de markt leiden tot het inzicht dat de kwaliteit van het produkt niet eenduidig en monotoon gerelateerd is aan het nut ${ }^{12}$. Een kwaliteitsverbetering kan een objectieve, maar ook een subjectieve kwaliteitsverbetering zijn. Belangrijk is slechts dat het individu een kwaliteitsverbetering als zodanig percipieert, omdat op basis daarvan keuzes gemaakt worden. Zo kan ook voor versehillende consumenten een verschillende rangordening van kwaliteitsalternatieven bestaan, doordat vorm en ligging van de individuele nutsfunctie afhankelijk is van het individu.

Lancaster's benadering gaat uit van voor de consument relevante produktkenmerken. Hierbij worden echter slechts de objectief meetbare kenmerken gespecificeerd. Hedonistische prijsfuncties leiden er toe dat van verschillende kenmerken het nut, in de vorm van een prijs, kan worden bepaald. Een voorwaarde is echter ook hier dat de kenmerken objectief meetbaar dienen te zijn.

Wanneer we de voor ons onderzoek bruikbare conclusies van genoemde theorieën onder I. en II. samenvatten blijkt dat:

1) In geen van de theorieën expliciet aandacht wordt besteed aan directe reacties van bestaande concurrenten als het gaat om concurrentie met produktkwaliteit.

2) Het zinvol is onderscheid te maken tussen verschillende soorten kwaliteitsverbeteringen.

3) Aan de aanbodzijde de micro-economische theorieên uitgaan van eenduidige en monotone relaties tussen hoeveelheid inputvariabelen en kwaliteitsniveau.

De uitbreiding van de genoemde modellen met een multidimensionele kwaliteit komt in het volgende hoofdstuk (3) aan de orde, evenals het onderscheid tussen verschillende 
soorten kwaliteitsverbeteringen.

In de volgende paragraaf (2.3.) zal het specifieke geval van de relatie tussen kwaliteitskosten (c.q. hoeveelheid inputvariabelen) en kwaliteitsniveau nader uitgewerkt worden, om aan te geven dat, afhankelijk van de vooronderstelling, deze relatie niet cenduidig monotoon hoeft te zijn.

\subsection{Kwaliteitskostenverloop en kwaliteitsniveau}

Wanneer we de vijf invalshoeken van Garvin overzien, wordt éen aspect bij twee benaderingen expliciet aan de orde gesteld. Zowel in de produktiegerichte benadering als in de produktgerichte benadering worden uitspraken gedaan over het verloop van de kwaliteitskosten op de weg naar het perfecte kwaliteitsniveau. Binnen de produktiegerichte benadering bestaan twee opvattingen (vergelijk Heskett, Sasser \& Hart 1990):

1. De gemiddelde kwaliteitskosten kennen een U-vormig verloop als het kwaliteitsniveau toeneemt (Garret \& Silver 1973, Lundvall \& Juran 1974, Feigenbaum 1983, Van Grinsven 1984). Eerst dalen de gemiddelde kwaliteitskosten. Als de perfecte kwaliteit dicht wordt genaderd nemen de gemiddelde kwaliteitskosten sterk toe. $\mathrm{Er}$ bestaat in deze opvatting dus een optimaal kwaliteitsniveau. De kosten die worden onderscheiden zijn:

a) Preventiekosten: Kosten die ontstaan teneinde fouten en inspectie te voorkomen. Deze kosten vertonen een exponentieel stijgend verloop bij toename van het kwaliteitsniveau.

b) Beoordelingskosten: Kosten om de toestand van het produkt te onderzoeken. Deze kosten vertonen een dalend verloop.

c) Foutenkosten: Foutenkosten worden vaak onderverdeeld in interne kosten (kosten die zouden verdwijnen warneer het produkt geen gebreken zou vertonen voor het de fabriek verlaat) en externe kosten (kosten die niet zouden bestaan wanneer er geen gebreken zouden voorkomen tussen het verlaten van de fabriek en het gebruiken door de consument). Foutenkosten vertonen een dalend verloop naarmate het kwaliteitsniveau toeneemt.

2. De kwaliteitskosten stijgen naarmate het kwaliteitsniveau stijgt. Omdat verlies van "goodwill" en toekomstige verkopen een veel belangrijker kostenpost vormen dan in de onder 1) genoemde benadering bestaat er geen optimaal kwaliteitsniveau. Men is beter af door te streven naar "zero defects" (Ross \& Shetty 1985, Takeuchi \& Quelch 1983).

Zowel de eerste als de tweede opvatting heeft consequenties voor de gebruikelijke microeconomische analyses. Hier zal het betoog van Koutsoyiannis ten aanzien van verticale kwaliteitsconcurrentie (1982; pp. 13-18) worden gevolgd, om daarna met een alternatief verloop van de gemiddelde kostencurves bij nadering van de perfecte kwaliteit rekening te houden.

In figuur 2.1. worden een aantal paarsgewijze vraag- en kostencurves gepresenteerd, telkens een andere kwaliteitsgraad van het produkt voorstellend. Gegeven is dat de vraag en de kosten toenemende functies zijn van kwaliteit. De paren vraag- en kostenfuncties 
die hoger en rechts liggen geven een hoger kwaliteitsniveau weer. Gegeven de marktprijs $P$, zullen de ondernemingen die vraag- en kostencurve-combinatie kiezen, die maximale winst oplevert.

Figuur 2.1.: Vraag- en kostencurves bij verschillende kwaliteitsniveaus (bron: Koutsoyiannis 1982; p. 14).

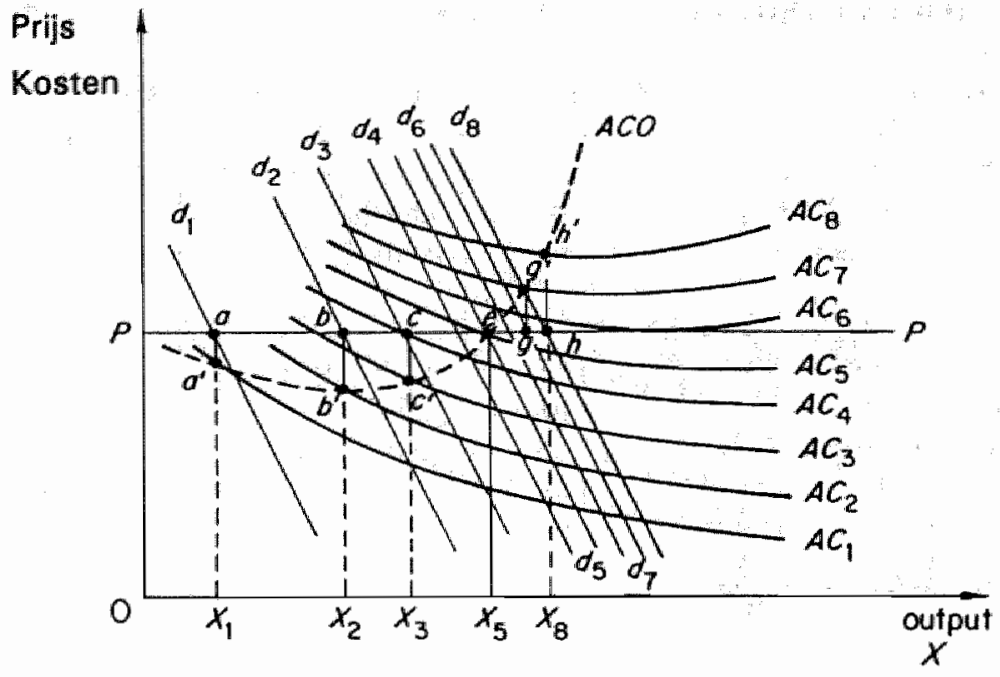

In figuur 2.1 geven de snijpunten (a $t / m$ h) van de prijslijn $P$ met de vraagcurves $d_{1} t / m$ $d_{8}$ de verkochte hoeveelheden weer op de $x$-as. De verkochte hoeveelheden zijn respectievelijk $X_{1} \mathrm{t} / \mathrm{m} \mathrm{X}_{8}$. Hierbij correspondeert $X_{1}$ met kwaliteitsniveau $1, X_{2}$ met het hogere kwaliteitsniveau 2 en zo verder. Wanneer de kwaliteit stijgt, treedt een verzadiging op. De verkochte hoeveelheden stijgen niet evenredig mee. De gemiddelde kosten (kostencurve $\mathrm{AC}_{1}$ ) bij kwaliteitsniveau 1 bedragen a', zodat er een winst per cenheid is van aa", gegeven P. Als de onderneming besluit om de kwaliteit te verhogen naar kwaliteitsniveau 2, zullen de gemiddelde kosten ' $b$ ' bedragen en zal een winst resulteren van b' per eenheid. Het break-even punt wordt bereikt wanneer kwaliteitsniveau 5 wordt geproduceerd. Wordt een hoger kwaliteitsniveau geproduceerd, dan ontstaan er verliezen.

Wanneer nu de punten a', b',...,h' worden verbonden dan ontstaat de zgn. "average cost option curve" (ACO in figuur 2.1). Deze curve geeft de gemiddelde kosten per eenheid aan voor de verschillende aangeboden kwaliteitsniveaus, gegeven een marktprijs $P$. Omdat de gemiddelde kostencurves U-vormig zijn verondersteld, heeft ook de ACO-curve een Uvormig verloop. Wanneer de kwaliteit wordt verbeterd, ontstaat er een tweeledig effect op de kosten (figuur 2.2.): 
1) De gemiddelde kosten stijgen; dat wil zeggen voor elk afzetniveau nemen de gemiddelde kosten toe. Dit effect wordt aangegeven door een verschuiving bij een gelijkblijvend afzetniveau $X_{1}$ van a' naar $a^{\prime \prime}$.

2) Wanneer de vraag toeneemt, als gevolg van de kwaliteitsverbetering, stijgt de afzet naar $X_{2}$. Hierdoor komen de gemiddelde kosten op een lager niveau $b^{2}$ te liggen.

Figur 2.2.: Tweeledig effect van kwaliteitswerbeteringen (bron: Koutsoyiannis 1982; p. 15).

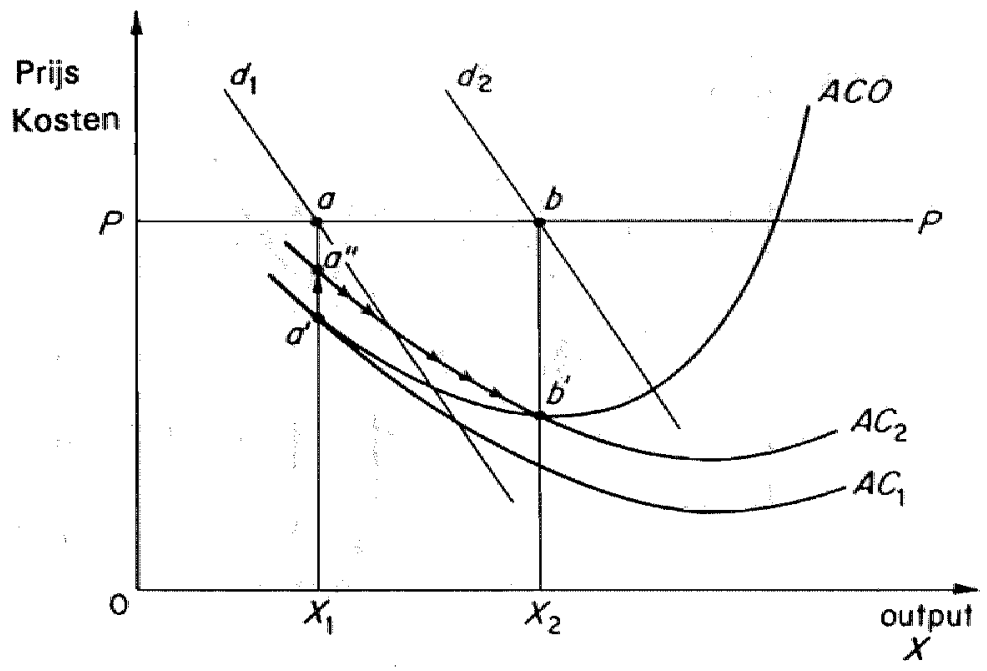

Zoals in figuur 2.1. is aangegeven stijgen de kosten met de toename van het kwaliteitsniveau:

Nu hebben, zoals verondersteld is in opvatting 1, de kostencurves geen monotoon stijgend verloop naarmate de perfectie wordt benaderd. De kostencurves kunnen wel gekenmerkt worden door een U-vormig verloop. Eerst gaat kwaliteitsverbetering gepaard met dalende kosten per eenheid. Dan volgt een omslagpunt, waarna de kosten per eenheid sterk gaan toenemen. Figuur 2.3. geeft weer de uitgangssituatie weer. Echter nu is het verloop van de kostencurves bij verschillende kwaliteiten anders. Curve $\mathrm{AC}_{2}$ ligt onder $\mathrm{AC}_{1}$, zodat bij een verbetering van de kwaliteit de kosten per eenheid dalen. Enerzijds is er een effect vanwege de lagere kosten per eenheid bij gelijkblijvende $X_{1}$ en anderzijds vanwege het effect van de grotere vraag op de kosten, langs de curve $\mathrm{AC}_{2}$. Beide effecten zijn in eerste instantie negatief. 
Figuur 2,3.: Wraag-en kostencurves bij werschillende Kwalliteitsniveaus.

$A C O^{\circ}, \mathrm{AC}_{1}^{\circ} \mathrm{V} / \mathrm{m} \mathrm{AC}_{3}^{\circ}=$ oude, in figur 2.1 . beschreven situatie.

$\mathrm{ACO}, \mathrm{AC}_{1}$ t/m $\mathrm{AC}_{4}=$ nieuwe situatie, met gewijzigd verloop van lkwaliteitskosten.

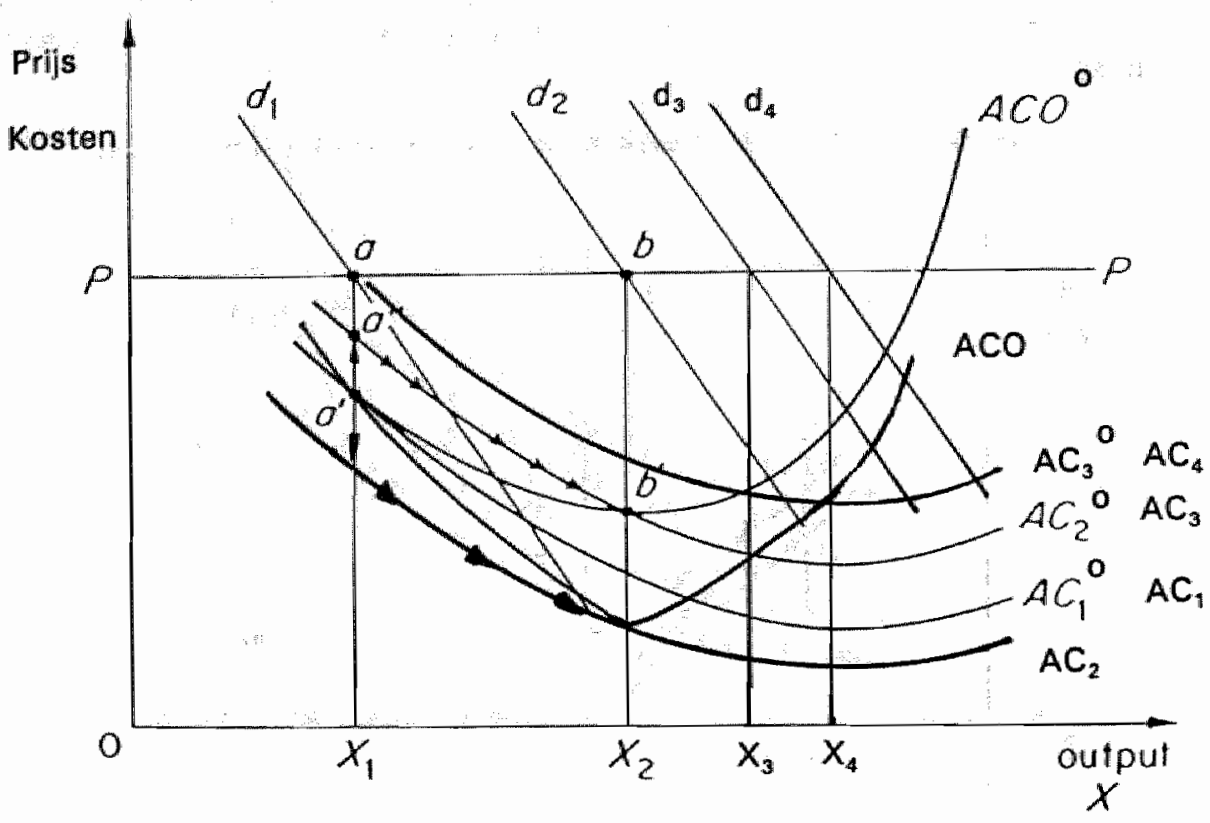

Het blijkt dat, uitgaande van de eerste opvalting, de ACO-curve voor het minimumpunt sterker daalt en na het minimumpunt sterker stijgt dan in het geval van lineair stijgende kosten. Er kan dus sprake zijn van zeer "gevoelige" concurrentie in het opgaande deel van deze curve. Kwaliteitsverbeteringen in de buurt van het minimum kostenniveau of het evenwichtspunt bij maximale winst gaan dus gepaard met relatief grote kosten-stijgingen. Uit onderzoek (Crosby 1979) is gebleken dat de meeste ondernemingen door kwaliteitsverbeteringen lagere gemiddelde kwaliteitskosten kunnen realiseren. Dit duidt erop dat ondernemers zich niet volledig bewust zijn van de kwaliteitskosten en men dus onvolledig is geinformeerd over het eigen kastenverloop. $\mathrm{Er}$ is dus nog een betere kwaliteit te realiseren tegen minder kosten. Komt de gehele bedrijfstak op het evenwichtspunt van maximale winst, dan wordt een kwaliteitsniveau geproduceerd dat hoger is dan bij minimale kwaliteitskosten. Het produceren bij minimale kwaliteitskosten houdt dus niet tevens in dat ook een optimaal kwaliteitsniveau wordt geproduceerd, gegeven winstmaximalisatie. De optimale kwaliteit zal hoger zijn dan de kwaliteit bij minimale kwaliteitskosten.

Wanneer het niet benaderen van de perfecte kwaliteit resulteert in een zodanig verlies aan goodwill en toekomstige verkopen dat de daarmee gepaard gaande kwaliteitskosten worden overtroffen (opvatting 2) heeft de curve een wezenlijk ander verloop. Er ontstaat nu een ander beeld waarbij de ACO-curve weer verder naar rechts komt te liggen, vanwege de niet meer degressief stijgende vraagcurve. De vraagcurve stijgt, onder invloed van goodwill en toekomstige verkopen, proportioneel of zelfs progressief. 
Het blijkt dus dat, afhankelijk van de vooronderstellingen, de relatie tussen kwaliteitskosten en kwaliteitsniveau niet eenduidig monotoon stijgend hoeft te zijn en afhankelijk is van het reeds bereikte kwaliteitsniveau. Voor de meeste bedrijven houdt dat in dat met een verhoging van de kwaliteit een verlaging van de gemiddelde kwaliteitskosten te bewerkstelligen is (Crosby 1979). Wanneer eenmaal het minimale gemiddelde kwaliteitskostenniveau is bereikt ontstaat, afhankelijk van de opvatting 1 of 2 , respectievelijk een meer of minder scherpe stijging van de kwaliteitskosten.

\subsection{Overzicht van kwaliteitsdefinities in de managementliteratuur}

Definities van kwaliteit komen vooral voor in de kwaliteitszorgliteratuur. In de marketingliteratuur neemt de behandeling van kwaliteitsvraagstukken een bescheiden plaats in, ondanks ons vermoeden dat het marketing-concept verwant is met het kwaliteitsconcept.

In deze paragraaf zal eerst (in paragraaf 2.4 .1 .) geïnventariseerd worden welke definities voorkomen in de wetenschappelijke managementliteratuur op het gebied van kwaliteitszorg en marketing, om het genoemde vermoeden te toetsen. Daarna wordt (in paragraaf 2.4.2.) kort ingegaan op de rol van kwaliteitsmanagement en marketingmanagement binnen de organisatie. Vervolgens wordt (in paragraaf 2.4 .3 .) een indeling gemaakt in interne en externe kwaliteit, om (in paragraaf 2.4.4.) te komen tot een classificatie van verschillende definities. Het doel van deze besprekingen is te komen tot een definitie van kwaliteit die bij ons empirisch onderzoek te hanteren is.

\subsubsection{Kwaliteitszorg en marketing}

Definities van kwaliteit worden vooral gevonden in de literatuur over kwaliteitsmanagement en kwaliteitszorg. Zoals in de inleiding is aangeduid komen slechts enkele definities van kwaliteit voor in de marketing-literatuur en wordt er verder inhoudelijk en voor wat betreft de consequenties voor marketing(strategieën) nauwelijks aandacht aan geschonken. Dat deze literatuur wel in toenemende mate kwaliteits-vraagstukken behandelt, is onder meer een gevolg van de grotere maatschappelijke aandacht voor dit fenomeen. Het is ook te verklaren : uit de duidelijke overeenkomsten tussen het "marketing-concept" en het "kwaliteitsconcept". Het gaat in beide gevallen in essentie namelijk om een optiek van "marktgerichtheid". Kasper (1990) concludeert vit een overzicht van de marketing-literatuur over dat onderwerp dat, aansluitend bij Narver \& Slater (1989), marktgerichtheid een drietal gedragscomponenten bevat, namelijk:

- Klantoriëntatie.

-Concurrentiegerichtheid.

-Coördinatie tussen de functionele eenheden in de organisatie.

De verwantschap tussen marketing-concept en kwaliteitsconcept kan als volgt nader toegelicht worden. Binnen de kwaliteitszorgliteratuur wordt kwaliteit veelal gedefinieerd als voldoen aan wensen van klanten en/of gebruikers. Er komen echter ook definities voor die de interne organisatie of de oriëntatie op de concurrent centraal stellen.

In de kwaliteitszorgliteratuur speelt de marktgerichtheid een rol voorzover het gaat om het vaststellen van de specificaties van het produkt. De specificaties worden vastgesteld op basis van de wensen en behoeften van de klant. Dit is vaak de eerste fase in het proces 
teneinde een hoge produktkwaliteit te realiseren (zie bijwoorbeeld Mulder 1989).

In de algemene marketing-literatuur staat qua richtinggevend concept ook de marktoriëntatie centraal. Webster (1988 1989) betoogt dan ook dat de marktgeoriënteerdheid zowel in marketing als in kwaliteitszorg hetzelfde inhoudt. Deze marktgerichtheid is tot nu toe binnen de marketing, vooral in het kader van consumentenmarketing en consumentengedrag bestudeerd.

Daarnaast wordt sinds de publicaties van de IMP-groep ${ }^{13}$ (Hakansson 1982, Ford 1982, Turnbull \& Valla 1986) bij industriële marketing het probleemoplossend vermogen centraal gesteld als concretisering van klantgerichtheid. Bij de daarmee gepaard gaande intensieve interactie met de klant speelt technische kwaliteit vaak een belangrijke rol, naast door afnemers gepercipieerde kwaliteit van dienstverleningsaspecten (Gummesson 1987).

In dienstenmarketing wordt het probleem van het "beheersen" van gepercipieerde kwaliteit eveneens aan de orde gesteld. Met name het "gezamenlijk" met de klant produceren van de dienst vraagt veel aandacht voor vraagstukken die handelen over het beheersen van de $k$ waliteit van dienstverlening.

Verder ligt de overeenkomst tussen tevredenheid/ontevredenheid van klanten en kwaliteit voor de hand. Parasuraman, Zeithaml \& Berry (1986) argumenteren dat kwaliteit het resultaat is van een reeks van ervaringen waarover men tevreden en/of ontevreden is geweest. $\mathrm{Zij}$ komen tot deze conclusie op basis van werk van Oliver (1981), die op dezelfde wijze een relatie legde tussen tevredenheid en attitude. Vraagstukken over tevredenheid en ontevredenheid zijn vraagstukken die sinds kort vrij sterk binnen de marketing worden bestudeerd.

Wetenschappelijke vorderingen op het terrein van onderzoek en theorievorming ten aanzien van kwaliteitsvraagstukken hebben zich veelal geisoleerd afgespeeld binnen de vakgebieden "kwaliteitszorg" en "marketing", terwijl, zoals reeds is aangegeven, hetzelfde uitgangspunt wordt gehanteerd, namelijk de marktgerichtheid. Dit wordt nog verder toegelicht in paragraaf 2.4.4., bij de bespreking van de diverse kwaliteitsdefinities.

\subsubsection{Kwaliteitsmanagement en marketing-management}

Het managen van kwaliteit (kwaliteitszorg) heeft te maken met, en is gericht op alle managementaspecten van een organisatie (Feigenbaum 1961, Mulder 1989). Zo is kwaliteitszorg van toepassing op zowel produktie-, administratieve, personeels-, financiële als marketing-activiteiten. Traditioneel echter heeft kwaliteitszorg zich voornamelijk op het produktieproces gericht (Takeuchi \& Quelch 1983).

Marketing (als verzameling activiteiten; Leeflang 1987; p. 6-7) is te omschrijven als:

".... het geheel van activiteiten dat door een arganisatie verricht of in gang gezet moet worden om de in- en uitgasnde "goederen" "stroom to reguleren."

en richt zich daarbij primair op de in- en uitgaande goederenstromen. 
Nu zijn er twee benaderingen van kwaliteitszorg te onderscheiden: de traditionele en de moderne benadering.

In de traditionele benadering richt kwaliteitszorg zich primair op het produktieproces en de ingaande goederenstroom. Kwaliteitszorg is direct gekoppeld aan produktiemanagement. Marketing richt zich op de uitgaande goederenstroom, en in het bijzonder verkoop. Ondanks de overeenkomstige uitgangspunten vormen marketing en kwaliteitszorg twee geïsoleerde functies binnen een organisatie.

In de moderne benadering krijgen alle functies te maken met kwaliteitszorg (integrale kwaliteitszorg); dus ook het marketing-management. Met andere woorden: als de wijze waarop activiteiten binnen de organisatie gestalte wordt gegeven (het "managen") centraal staat (vergelijk marketing als functie; Leeflang 1987, Gummesson 1987) is voor wat marketing betreft de kwaliteit van de marketing-functie in het geding. Bonoma (1985) geeft aan dat deze kwaliteit sterkt samenhangt met de wijze waarop het marketingmanagement met de implementatie van een strategie omgaat om te komen tot een gewenst resultaat, in termen van marktaandeel of winst.

Wordt de verzameling activiteiten centraal gesteld dan wordt duidelijk dat zowel marketing als kwaliteitszorg verantwoordelijk zijn voor het produktbeleid en derhalve aandacht besteden an het produktkwaliteit. Produktontwikkeling, produktkwaliteit, produktie en afzet zijn de kernbegrippen van het produktbeleid. Hiermee is aangegeven dat in de moderne benadering substantiële overlappingen bestaan als het gaat om zowel de activiteiten als functies binnen de organisatie die invloed hebben op het produktbeleid van de onderneming. Het produktbeleid is vervolgens van belang als het gaat om produktkwaliteitsverbeteringen.

\subsubsection{Interne en externe kwaliteitszorg}

De kwaliteit van een produkt is voor de producent vaak synoniem met de kwaliteit van het fysieke produkt. In deze context wordt de kwaliteit gemeten in zuiverheid of klasse van gebruikte materialen, de technische perfectie van het ontwerp of de mate van overeenstemming met de meetbare produktnormen. Wanneer eenmaal een kwaliteitsniveau is vastgesteld, voeren bedrijven vaak een kwaliteitsbeheersings-programma uit, gericht op kwaliteitscontrole tijdens het produktieproces, om aan de vooraf opgestelde normen te voldoen (Crosby 1979). Deze benaderingswijze, die enigszins een ontkenning inhoudt van een continue oriëntatie op de klant, is gericht op de overeenstemming met de specificaties en wordt genoemd de "internal view of quality".

Daarnaast moet echter rekening gehouden worden met de mate waarin het produktontwerp wordt afgestemd op de behoeften van de klant. Wordt deze behoefte continu als uitgangspunt genomen, dan wordt van de "external view of quality" gesproken (Juran, Gryna \& Bingham 1974, Vinson \& Heany 1977, Garvin 1983). Bij de classificatie van de verschillende kwaliteitsdefinities zal deze tweedeling tussen interne en externe kwaliteit worden gebruikt.

\subsubsection{Classificatie van kwaliteitsdefinities}

Bij de classificatie van definities is de vindplaats van de definitie een criterium; gaat het om kwaliteitszorgliteratuur of om marketing-literatuur? Tevens wordt uitgegaan van de hiervoor genoemde indeling in interne en externe kwaliteit. De definities zullen in categorieën worden ondergebracht, die de kern van de definitie weergeven. Deze exercitie 
is van belang om vast te kunmen stelien in hoeverre definiëring in de kwaliteitszorgliteratuur anders geschiedt dan in de marketing-literatuur. Daartoe zijn de kwaliteitsdefinities telkens ondergebracht bij Cén van de volgende categorieën:"

1. Overeenstemming met specificaties; het voldoen van het produkt aan de daarvoor opgestelde specificaties.

2. Gebruik; de geschiktheid van het produkt voor gebruik door klant of consument.

3. Behoeften en/of wensen; de mate waarin aan behoeften en/of wensen van klanten of consumenten wordt voldaan.

4. Doel(en); de mate waarin produkten geschikt zijn voor bepaalde doel(en) waarvoor het produkt gebruikt wordt.

5. Verwachtingen; de mate waarin het produkt tegemoet komt aan de verwachtingen van klanten of consumenten.

6. Concurrentie; de prestaties van het produkt ten opzichte van de concurrerende produkten.

Schema 2.1. geeft de indeling weer van de kwaliteitsdefinities door middel van de naam van de auteur(s). Bijlage A geeft de volledige omschrijvingen van de definities.

De kwaliteitszorgliteratuur geeft zowel formuleringen te zien die uitgaan van het interne kwaliteitsconcept, het externe kwaliteitsconcept of van een combinatie van beiden (Schaafsma \& Willemze, Gilmore). In de marketing-literatuur daarentegen gaan de aangehaalde auteurs uit van de externe kwaliteitsvisie. Dit ligt voor de hand vanwege de inherente marktgeoriënteerdheid van het marketing-vak.

Binnen de externe kwaliteitsvisie komt een veelheid aan omschrijvingen voor, die alle gericht zijn op de klant of de concurrent. Deze omschrijvingen met behoeften en/of wensen van de klant en vergelijking met de concurrentie wijken enigszins af van de definitie van het marketing-concept (Leeflang 1987) en de marktgerichtheid (Narver \& Slater 1989). Twee van de drie eerder genoemde componenten van marktgerichtheid komen in de verschillende definities naar voren, namelijk klant- en concurrentiegerichtheid. De derde component, de coördinatie tussen de functionele eenheden in de organisatie, wordt niet afgedekt in de externe kwaliteitsvisie.

Voorts, kan worden geconcludeerd dat de kwaliteitsdefinities uit de marketing-literatuur een deelverzameling vormen van de kwaliteitsdefinities uit de kwaliteitszorgliteratuur. Het meest frequent wordt kwaliteit gedefinieerd in termen van het zo goed mogelijk voldoen aan de wensen en behoeften van de klant.

Wanneer een vergelijking wordt gemaakt met de drie componenten van marktgerichtheid blijkt dat in de kwaliteitszorgliteratuur alle drie de elementen terugkomen in de definitie van kwaliteit. De klantgerichtheid blijkt uit de al eerder genoemde aansluiting bij de wensen en behoeften van klanten. De concurrentiegerichtheid blijkt uit de vergelijking met de concurrentie (relatieve kwaliteit). Tenslotte, de coördinatie tussen functionele eenheden binnen de organisatie, heeft veel raakvlakken met de interne kwaliteitsvisie, waarin de interne organisatie in feite centraal staat, om aan de specificaties van het produkt te kunnen voldoen. Dit hangt ook samen met het interne marketing-concept, dat gehanteerd kan worden om "commitment" tussen functionele eenheden te bereiken. 
Centraal in definitie Indeling:

Management-literatuur:

Marketing-literatuur:

\title{
INTERNE KWALITEIT:
}

overeenstemming met specificaties

\author{
Schaafsma \& Willemze (1954) \\ Gilmore (1974) \\ Crosby (1979) \\ Luchs (1986) \\ Goodmeasure (1988) \\ Hall (1990)
}

\section{EXTERNE KWALITEIT:}

gebrailk

Juran (1974)

Muldler (1989)

Genth (1981)

Eidwards (1968)

Kotler (1984)

behoeften en/of wensen

Gilmore (1974)

Kueln \& Day (1962)

van Ettinger (1974)

Colenbrander(1970)

Fremery \& van Lier (1975)

Maynes (1976)

Mulder (1976)

Box (1984)

Geiger $\left(1977^{14}\right)$

Leeflang (1987)

Ishikawa (1985)

Khuwers Handboek

Kwaliteitsbeleid (1987)

ISO Draft Guide (198915)

doelen

Schaafsma \& Willemze (1954)

Veen (1980)

Seanlon \& Hagan (1986)

verwachtingen

Feigenbaum (1961)

Castillo (1974)

Feigenbaum (1983)

Berry (1986)

concurrenten

Shetty \& Buehler (1985)

Monroe \& Krishnan

(1985)

Uit het bovenstaande blijkt dat het samenstel van kwaliteitsdefinities uit de kwaliteitszorg beter aansluit bij de marktgeoriënteerdheid dan het samenstel van definities uit de marketing-literatuur. Immers, de marketing-literatuur behandelt slechts de externe kwaliteitsdefinities.

Geciteerd in: Hilverdink (1979), p. 92 .

Gebaseerd op EOQC-Glossary Committee (eds.), 1976, Glossary of Terms used in Quality Controll, 4th ed., i. 16. 
Fen tweede bevinding is dat de definities van kwaliteit telkens afzonderlijk gebaseerd worden op slechts éen kenmerk. Naar voorbeeld van de drie componenten van marktgeoriënteerdheid zou ook de kwaliteitsdefinitie uit de genoemde drie componenten dienen te bestaan. Dit concluderend, verschilt marktgeoriënteerdheid niet meer wezenlijk van de kwaliteitsorientatie en is het een taak van de marketing om kwaliteitszorgaspecten sterker te integreren in het huidige vakgebied. De huidige kwaliteitsdefinities in de marketing-literatuur verdienen derhalve een aanpassing, waarbij naast aandacht voor de driedeling van de definitie van kwaliteit, specifiek aandacht moet worden besteed aan de coördinatie-component. Deze component is in de literatuur over dienstenmarketing reeds van eminent belang (zie bijvoorbeeld Parasuraman, Zeithaml \& Berry 1985, Zeithaml, Berry \& Parasuraman 1987, Gummesson 1987).

In ons onderzoek wordt (produkt)kwaliteit dan ook gedefinieerd als het zo goed mogelijk voldoen aan de wensen of behoeften wan de klant, 1) rekening houdend met de relatieve kwaliteitspositie ten opzichte van de concurrentie en 2) de interne afstemming ("commitment") binnen het produktieproces om ook daadwerkelijk dat produkt te leveren.

\subsection{Kwaliteit gemeten}

Uit een onderzoek van het Amerikaanise blad Fortune ${ }^{16}$ bij directieleden van ondernemingen en consumenten blijkt dat $13 \%$ van de directieleden de laatste jaren een verslechtering van de kwaliteit van produkten percipieert. Van de consumenten gaf $49 \%$ aan dat de produktkwaliteit verslechterd was. Hieruit blijkt het verschil in kwaliteitsperceptie tussen ondernemer (producent) en afnemer. In diverse onderzoeken (Schneider, Parkington \& Buxton 1980, Parasuraman, Zeithaml \& Berry 1985, Kasper \& Lemmink 1989 ) is ook aangetoond dat de kwaliteitsperceptie verschilt tussen het management van de onderneming en de klanten.

Deze bevindingen leiden tot de conclusie dat onderscheid moet worden gemaakt tussen het meten en beoordelen van de kwaliteit door de onderneming zelf (door bijvoorbeeld het management van de onderneming) en de klanten, omdat er verschil in kwaliteits-perceptie bestaat. Daarnaast zal nog een derde invalshoek onderscheiden worden, namelijk die van de testinstanties en belangenorganisaties, zoals de Stichting Vergelijkend Warenonderzoek en de Consumentenbond, die als sén van haar doelstellingen heeft professionele vergelijkingen tussen produkten te maken en te publiceren. Voor een totaaloordeel over de kwaliteit zouden de verschillende invalshoeken gecombineerd moeten worden. Vanwege onder andere de complexiteit van een dergelijke analyse wordt in wetenschappelijk onderzoek tot nog toe telkens voor én van die invalshoeken gekozen. In het vervolg van deze paragraaf zal worden aangegeven welke pogingen er zijn gedaan de kwaliteit te meten vanuit de drie genoemde invalshoeken, management, klanten en testinstanties en belangenorganisaties.

Daarbij zal het management meer aandacht krijgen omdat in het empirische gedeelte van ons onderzoek de partiële analyse op basis van het management gekozen wordt.

In het PIMS (Profit Impact of Market Strategies)-onderzoek wordt de invalshoek vanuit het management gekozen. Uiteraard ontstaat bij een dergelijke werkwijze een ver- 
tekening, doordat niet direct aan de klanten een oordeel is gevraagd, maar men zich baseert op ondernemersoordelen. Er wordt getracht de mogelijke vertekening in de antwoorden te minimaliseren, door in de vraagstelling naar consumentenoordelen te vragen, zo mogelijk gebaseerd op marktonderzoeken. De vraag die wordt gesteld aan het management is:

"For each year, estimate the percentage of your sales volume accounted for by products and services that from the perspective of the customer are assessed as "superior", "equivalent" and "inferior" to those available from leading competitors" $"$ "

De managers kunnen bij beantwoording gebruik maken van intern beschikbare gegevens als klanten-/marktonderzoeken, produkt- en laboratorium-testen. De kwaliteitsschatting heeft betrekking op het tastbare produkt (inclusief installatie, service en garantie). De prijs van het produkt wordt dus uitdrukkelijk uitgesloten. In de PIMS-onderzoeken loopt de range van kwaliteitsindexen van $-25 \%$ tot $+80 \%$, met een gemiddelde van $22 \%$. Dit houdt in dat de onderneming denkt dat uit oogpunt van de klant gemiddeld $22 \%$ van de verkopen, produkten en diensten betreft waarvan de kwaliteit beter is dan van de "leading competitors"'. De gehanteerde methode levert onder meer de volgende problemen op:

1. Er wordt aangenomen dat alle ondervraagden even goed op de hoogte zijn van de door de consument gepercipieerde kwaliteit.

2. Het is een nadeel dat slechts een vergelijking plaatsvindt met de belangrijkste concurrenten, maar maakt in feite empirisch onderzoek niet onmogelijk.

Het eerste nadeel is gedeeltelijk te ondervangen door de nieuwe, sinds 1983 door PIMS gehanteerde vraagstelling. De vraagstelling is namelijk uitgebreid met twee vragen. Deze luiden (Gale \& Klavans 1984; p. 21):

"Identify what your customers usually cite as the major attributes of quality and the relative importance of each attribute....For each attribute determine how customers rate performance of your business and its major competitors".

Er bestaan nog meer methodologische problemen ten aanzien van de door PIMS gehanteerde methodiek. Voor een uitgebreide uiteenzetting over de problemen die bij dit onderzoek in het algemeen spellen, wordt verwezen naar Jacobson \& Aaker (1987) en Buzzel \& Gale (1987). Ten aanzien van het onderwerp produktkwaliteit maken Jacobson \& Aaker kritische opmerkingen over het feit dat de meting bestaat uit een index. Immers; verschillende samenstellingen van kwaliteitsprodukten kunnen dezelfde index opleveren. Verder is de meting gebaseerd op oordelen van het management ten aanzien van de klantenpercepties, in plaats van direct naar de percepties van klanten te vragen. De oordelen kunnen vertekend worden door de reeds genoemde optiekverschillen, de complexiteit van de oordeelstaak en onverschilligheid van de respondent. Ondanks deze en andere kritiek concluderen Jacobson \& Aaker dat de metingen valide zijn. Ten aanzien van de rol van relatieve produktkwaliteit komen zij, op basis van longitudinaal onderzoek met behulp van de PIMS-database, tot de volgende conclusie ten aanzien van de $\mathrm{ROI}$ kwaliteits-index $=$ (\% werkopen superieure produkten $)-(\%$ verkopen inferieure produkten $)$. 
(Jacobson \& Aaker 1987; p. 39):

"..... the resulls suggest that quality has a direct positive effect on profitability".

Dit is een bevestiging van eerder empirisch PIMS-onderzoek van Schoeffler, Buzzel \& Heany (1974). Verder is hun conclusie ten aanzien van het effect van produktkwaliteit op het marktaandeel (p. 40):

"..... after controlling for other factors, produets of bigher quality are favored and will receive a higher share of the market.... Quality also seems to have a positive indirect effect on market share given quallity"s positive effect on price and, counter to theory and intuition, the apparent effect of price on market share.".

Jacobson \& Aaker komen tot de conclusie dat hogere relatieve prijzen leiden tot een hoger marktaandeel. Dit is in tegenstelling tot de theorie dat door lagere kosten en derhalve ook lagere prijzen schaalvoordelen zijn te behalen, resulterend in een hoger marktaandeel.

Er bestaan ook methoden om de kwaliteitspercepties bij consumenten zelf te meten. Dan kan gebruik worden gemaakt van technieken waarbij direct naar beoordelingen en belangscores van produkteigenschappen en dienstverlening wordt gevraagd, of waarbij door de consument afwegingen gemaakt worden tussen eigenschappen van het produkt. Omdat de kwaliteit door de consument zelf wordt bepaald, is er geen sprake van optiekverschillen. In de traditie van onderzoek naar het consumentengedrag bestaan erg veel studies die aspecten van het tot stand komen van kwaliteitsbeoordelingen en de beeldvorming van kwaliteit bij consumenten, onderzoeken ${ }^{18}$.

Een derde invalshoek om de kwaliteit te meten, is vanuit professionele testinstanties en belangenorganisaties. Dit kunnen instanties of organisaties zijn die door de overheid zijn aangewezen om een objectief oordeel over de kwaliteit te geven, maar ook instanties die door consumenten in het leven zijn geroepen om een oordeel over de kwaliteit van produkten te geven (bijvoorbeeld in Nederland de Consumentenbond). Deze laatste instanties hebben een eigen visie, gebaseerd op het belang voor de consumenten. Zo is er in het algemeen een grote aandacht voor veiligheidsaspecten. Consumentenorganisaties voeren regelmatig kwaliteitsvergelijkingen tussen produkten uit. Hierbij worden met name objectieve criteria gebruikt. De waardering geschiedt op ordinaal niveau, en loopt vaak van - (zeer slecht) tot ++ (zeer goed).

Curry (1985) bijvoorbeeld heeft gebruik gemaakt van dergelijke gegevens over een lange periode om tot analyses van ontwikkelingen in kwaliteitswaarderingen te komen van concurrerende produkten in onder andere de markt voor huishoudelijke apparatuur. Daartoe werden de ordinale testgegevens getransformeerd naar intervalniveau. Curry \& Riesz (1988) hebben vervolgens gebruilk gemaakt van vergelijkbare gegevens van de Consumentenorganisaties in diverse landen en in een longitudinaal onderzoek de gegevens geanalyseerd. Daardoor werd het mogelijk om uitspraken te doen over de ontwikkeling van de kwaliteit en de prijs van verschillende categorieën consumentengoederen in de tijd. 
Het bleek dat na verloop van tijd managers uitgaven ten behoeve van kwaliteitsverbeteringen inkrimpen en uitgaven aan communicatie met de klant vergroten. Dit gebeurt vooral bij de producenten met een kwalitatief goed produkt en overeenkomstige prijzen. Een eerste reden voor een dergelijke handelwijze van managers is dat met behulp van communicatie-inspanningen de produktkwaliteiten duidelijk worden gemaakt bij de afnemers, om de prijs te rechtvaardigen. Een tweede reden is om op deze wijze een barrière op te werpen voor mogelijke toetreders met een produkt van lage kwaliteit met een lage prijs.

\subsection{Produktkwaliteitsverbeteringen (PKV'n)}

Alvorens een model voor de beschrijving van produktkwaliteitsverbeteringen (PKV'n) te ontwikkelen is het zinvol een PKV te definiëren. Zoals eerder in dit hoofdstuk is aangegeven is het uitgangspunt voor de definitie het tastbare produkt plus de door de consument daarvan afgeleide eigensehappen. Onder kwaliteit wordt verstaan het zo goed mogelijk voldoen aan de wensen of behoeften van de klant, 1) rekening houdend met de relatieve kwaliteitspositie ten opzichte van de concurrentie en 2) de interne afstemming ("commitment") binnen het produktieproces om ook daadwerkelijk dat produkt te leveren. Voor het afbakenen van de PKV zijn er nu nog een drietal problemen op te lossen:

1. Het onderscheid tussen PKV en nieuw produkt.

2. PKV'n en kwaliteitsverbeteringen in het produktieproces.

3. Strategische versus operationele beslissingen ten aanzien van PKV'n.

\subsubsection{PKV of nieuw produkt?}

Onder de randvoorwaarde van bovenstaande omschrijvingen van produkt en kwaliteit kan een PKV variëren tussen een kleine aanpassing van éen onderdeel van het produkt, tot het op de markt brengen van een voor de consument en onderneming volledig nieuw produkt (volgens Booz, Allen \& Hamilton 1982; "new to the world"). Voor het afbakenen van de PKV'n zal enerzijds een zekere "bovengrens" worden gesteld en anderzijds een zekere "ondergrens", bijwoorbeeld gevormd door een marginale PKV (vgl. Booz, Allen \& Hamilton 1982, Martin 1984, Normann 1971).

Booz, Allen \& Hamilton (1982) verdelen het begrip "nieuw produkt", volgens een eigen definitie, in zes afnemende categorieën, die de mate van "nieuw zijn van een produkt" aangeven:

1. Produktinnovatie.

2. Nieuwe produktgroep/produktlijn.

3. Toevoegingen aan bestaande produktgroepen.

4. Produktmodificatie.

5. Herpositionering van het produkt.

6. Kostenreducties.

Een PKV kan nu een verbetering zijn van de kwaliteit van bestaande produkten, gericht op 3) $t / m$ 5). Produktinnovaties (1) en nieuwe produktgroepen/lijnen (2) vallen buiten het bestek van dit onderzoek. Kostenreducties sec (6) zijn in ons onderzoek niet opgevat als 
een kwalliteitswerbetering, omdat de prijsaspecten buiten het kwaliteilsbegrip wordt gelaten.

Foxall (1984) geeft een andere indeling. Hij gaat uit van verschillende typen innovaties, die gekenschetst kunnen worden als:
1. Continu.
2. Dynamisch continu.
3. Differentiêtle innowaties.
4. Radicale doorbraken.

Hij concludeert dat in de praktijk $70 \%$ van de innovaties continu zijn. Deze innovaties, en bovendien de dynamisch continue innovaties kunnen met name worden begrepen binnen de definitie van een $P K V$.

De reden voor deze afbakening is dat wanneer de uiterste grenzen gehanteerd worden, het scala aan PKV'n erg breed wordt, zodat bijvoorbeeld radicale innovaties naast marginale produktmodificaties kunnen worden aangemerkt als PKV. In ons onderzoek is de keuze gemaakt om de PKV'n die aangemerkt kunnen worden als nieuwe produkten niet in het onderzoek mee te nemen. Als bijvoorbeeld een onderneming, vanwege de introductie van een volledig nieuw produkt, wordt geconfronteerd met nieuwe concurrenten (op nieuwe markten) ontstaat een aanmerkelijk complexere concurrentie-situatie dan in het gevall van reeds bestaande concurrenten. Fen produktinnovatie zal waarschijnlijk ook een duidelijk ander reactiegedrag van bestaande concurrenten bewerkstelligen en mogelijk reacties van nieuwe concurrenten uillokken.

\subsubsection{PKV'n en kwaliteitsverbeteringen in het produktieproces}

Met name in de kwaliteitszorgliteratuur wordt veel aandacht besteed aan de kwaliteit van het produktieproces; de interne kwaliteit. Wordt de kwaliteit van het produktieproces verbeterd, dan hoeft nog geen sprake te zijn van een PKV (zie voor dit onderscheid ook Knight 1967, Utterback \& Abernathy 1975) . Echter verbeteringen aan de kwaliteit van het produktieproces, die leiden tot een hogere kwaliteit van de produkten vallen uiteraard wel onder onze definitie van PKV.

\subsubsection{Strategische versus operationele beslissingen ten aanzien van PKV'n}

Verder staan in dit onderzoek de operationele beslissingen ten aanzien van PKV'n centraal en niet de invloed van en reacties op strategische besllissingen. Omdat reacties ten aanzien van strategieen vaak een ingrijpender en veel meer omvattend karakter hebben, is het niet eenvoudig enduidig de reactie(s) van concurrenten te signaleren, als die reacties al te herleiden zijn tot reacties naar aanleiding van de betreffende strategieverandering. Om die reden is besloten om operationele PKV' $n$ als onderwerp van analyse te nemen, zonder in te gaan op de interferentie met mogelijke kwaliteitsstrategieën. Bij de analyse van de acties en reacties ten aanzien van PKV'n wordt de strategie als een constante verondersteld. Met andere woorden, de strategie wordt beschouwd als een gegeven.

Wanneer het voorgaande wordt samengevat dan zal het onderzoek gericht zijn op produktkwaliteitsverbeteringen. 
Daarbij wordt als produkt gezien het tastbare produkt, inclusief de bijbehorende door de consument toegevoegde eigenschappen, en

wordt een kwaliteitsverbetering omschreven als een herpositionering, produktmodificatie of een toevoeging aan bestaande produktgroepen die in sterkere mate tegemoet komt aan de wensen of behoeften van de klant. Daarbij wordt 1) rekening gehouden met de relatieve kwaliteitspositie ten opzichte van de concurrentie en 2) de interne afstemming ("commitment") binnen het produktieproces om ook daadwerkelijk dat produkt te leveren.

Een produktkwaliteitswerbetering (PKV) is een zodanige verbetering van het tastbare produkt, inclusief de bijbehorende door de consument toegevoegde eigenschappen dat in sterkere mate dan voorheen wordt tegemoet gekomen aan de wensen en/of behoeften van de klant. Daarbij wordt 1) rekening gehouden met de relatieve kwaliteitspositie ten opzichte van de concurrentie en 2) de interne afstemming ("commitment") binnen het produktieproces om ook daadwerkelijk dat produkt te leveren. 


\section{Produktkwaliteitsverbeteringen en concurrentiële reacties}

In dit hoofdstuk wordt de literatuur besproken die inzicht kan verschaffen over produktkwaliteitsverbeteringen en concurrentiële reacties. Daarvoor zal eerst in paragraaf 3.1. kort aandacht worden besteed aan de strategische aspecten. Vervolgens komen in paragraaf 3.2. de verschillende soorten PKV'n aan de orde en in paragraaf 3.3 . de concurrentiële reacties. Tot slot worden in paragraaf 3.4. de parallellen besproken met de "industriële economie" en de marktmodellering met behulp van econometrische modellen.

\subsection{Ondernemingsstrategie, kwaliteitsstrategie en PKV'n}

Kollat, Blackwell \& Robeson (1972) maken een indeling van strategieën in een aantal ontwikkelingsrichtingen voor ondernemingen op basis van produkten, markten en technologieën. De ontwikkelingsrichtingen van ondernemingen op basis van produkt en markt combinaties, met als onderscheid bestaand en nieuw (Ansoff 1965) vormen daarbij het uitgangspunt. Kollat, Blackwell \& Robeson brengen een verfijning aan en maken onderscheid tussen enerzijds produktaanpassingen en nieuw produkt en anderzijds verwante- en niet verwante technologie. Dit leidt tot het volgende schema.

Schema 3.1.: Ontwikkelingsrichtingen van de onderneming op basis van produkten, markten en technologieën (bron: Kollat, Blackwell \& Robeson 1972; p. 23).

Markten Produkten en technologieen

\begin{tabular}{|c|c|c|c|c|}
\hline$: \cdots$ & $\begin{array}{l}\text { Huidige } \\
\text { produkt }\end{array}$ & $\begin{array}{l}\text { Aanpassingen } \\
\text { produkt }\end{array}$ & $\begin{array}{l}\text { Nieuw prodult met } \\
\text { bestaande/verwante } \\
\text { technologie }\end{array}$ & $\begin{array}{l}\text { Nieuw produkt zonder } \\
\text { bestnande/verwante } \\
\text { technologie }\end{array}$ \\
\hline Huidige afnemers & Penetratie & Modificatie & Uitbreiding & Parallellisatie \\
\hline Nieuwe afnemers & Marktontwikkeling & Marktverbreding & $\begin{array}{l}\text { Concentrische } \\
\text { diversificatie }\end{array}$ & $\begin{array}{l}\text { Laterale } \\
\text { diwersificatie }\end{array}$ \\
\hline
\end{tabular}

Op basis van dit schema kan worden aangegeven op welke wijze een PKV hierin een plaats kan krijgen. Een kwaliteitsstrategie kan gedefinieerd worden als een strategie die tot doel heeft het verbeteren of handhaven van de relatieve kwaliteit (ten opzichte van de concurrentie) van het totale produkt. Een kwaliteitsstrategie kan daarbij zowel gericht zijn op de huidige afnemers van een produkt of dienst als op nieuwe afnemers. In het genoemde schema kan dientengevolge normaliter een kwaliteitsstrategie voorkomen bij elke ontwikkelingsrichting van de ondernemingsstrategie, behalve wanneer sprake is van handhaving van het huidige produkt. Immers, men mag er vanuit gaan dat in de meeste markten sprake is van een autonome trendmatige verbetering van de produktkwaliteit.

Strategieèn worden meestal geformuleerd en geïmplementeerd voor een periode van twee tot vijf jaar. De realisatie van een kwaliteitsstrategie vergt volgens Reddy (1980) gemiddeld vijf tot tien jaar. Er zijn enkele jaren nodig voor implementatie op 
produktieniveau. Daama vergt het nog enige tijd totdat de klanten er iets van merken. In de regel duurt het dus wijf tot tien jaar voordat alle voordelen van een kwaliteitsstrategie gerealiseerd zijn.

Een PKV wordt door ons opgevat als een nadere operationele invulling van de ondernemingsstrategie, en de daarvan afgeleide kwaliteitsstrategie. Binnen een kwaliteitsstrategie liggen PKV'n, met een operationeel ${ }^{9}$. karakter, voor de hand. Dat siuit echter niet uit dat er PKV'n voor kunnen komen als invulling van een andere marktstrategie, zoals het richten op een marktnis met een goed op de klantenwensen aansluitend produkt. PKV'n yallen in het bovenstaande schema onder produktaanpassingen. Daarbij is het duidelijk dat PKV'n plaatsvinden bij huidige afnemers; dus de huidige markt van het produkt dat wordt aangepast. Een PKV kan dus opgevat worden als een produktmodificatie in de terminologie van schema 2.1 ..

PKV"n vallen dus in het bovenstaande schema 2.1. onder modificatiestrategieên. Door huidige produkten aan te passen, tracht men bij de huidige afnemersgroepen een hoge(re) omzet/afzet/marktaandeel te realiseren. Zoals is aangeduid in hoofdstuk 2 zal dit onderzoek deze operationele PKV'n betreffen, en niet de strategie.

\subsection{Verschillende soorten produktkwaliteitsverbeteringen (PKV'n)}

Kwaliteil is multidimensionaal. Derhalve zijn produktwaliteitsverbeteringen veelal in meer dan één richting te realiseren. Het is zelfs aan te bevelen zorgvuldig één (of enkele) richting(en) te selecteren waarin men een concurrentieel voordeel wil behalen. Zoals Clark (1961; p. 245) het stelt:

"....it [competition] can focus strongly on some kinds of quality and neglect others; it can concentrate on adapting its offerings to the modal preferences of a mass market....., or th can cultivate, in varying degree, the variant preferences of minority groups".

Garvin (1984b; p. 42) concludeert:

"A firm is likely to be more succesful in pursuing a strategy of high product quality if it selects a small number of dimensions on which to compete, and then tailors them closely to the needs of its chosen market" [vet: JL].

Blijkbaar is het zinvol onderscheid te maken tussen verschillende soorten PKV'n. In deze paragraaf worden de verschillende indelingen in soorten PKV' $n$ besproken:

1. Formele micro-economische analyse. Zo kan in analyses van PKV'n het multidimensionele karakter van kwaliteit benadrukt worden. Formele microeconomische analyses kunnen bijvoorbeeld worden uitgevoerd met een produkt met een multidimensionele kwaliteit. PKV'n kunnen dan op basis van elk van die dimensies of een samenstel van dimensies plaatsvinden.

Met een termijj van $\leq 2$ jaar, vergelijkbaar met uitgangspunten van in empirisch onderzoek van Biggadike (1979) en Robinson (1988). Deze empirische onderzoeken zullen in het vervolg van dit boofdstuk nog uitgebreid aan de orde komen. 
2. Abbott (1955). In de micro-economische onderzoekstraditie maakte Abbott (1955) reeds een onderscheid tussen verticale, horizontale en innovatieve kwaliteitsverbeteringen.

3. In de meer recente marketing(-management) literatuur (tekstboeken) worden uitspraken gedaan over verschillende typen produktverbeteringen.

4. Garvin (1984b) presenteerde een indeling in acht categorieèn.

5. Indelingen van Kyj (1987) en Thams (1984).

In de volgende paragrafen 3.2.1. tot en met 3.2.5. zullen deze vijf alternatieve indelingen achtereenvolgens worden besproken.

3.2.1. Het multidimensionale kwaliteitsbegrip bij een micro-economische benadering Het resultaat van de formele micro-economische analyses is dat de verhouding tussen twee kwaliteitseigenschappen (dimensies) bij het streven naar maximale winst optimaal is, wanneer de verhouding van de marginale opbrengsten als gevolg van de verbetering van die kwaliteitseigenschap gelijk is aan de verhouding van de marginale kosten van de verbetering van dat kwaliteitsaspect. Er kan worden aangetoond ${ }^{20}$ dat, als wordt afgezien van een concurrentiële reactie, van een optimale kwaliteitsmix tussen twee kwaliteitseigenschappen sprake is wanneer de verhouding tussen de prijselasticiteiten gelijk is aan de verhouding tussen de kostenelasticiteiten.

Om de consequenties te illustreren zal een voorbeeld gegeven worden van een automobielfabrikant. Stel dat er slechts twee relevante kwaliteitseigenschappen zijn; de kwaliteit van de auto zelf $(Q)$ en de kwaliteit van de service $\left(Q_{2}\right)$. De gebruikelijke afzeten kostenrelaties zijn van toepassing (bijlage B) en de concurrentie reageert niet op een kwaliteitsverbetering. Verder vertoont de kostenfunctie een exponentieel stijgend verloop naarmate de kwaliteit toeneemt. Dit laatste is gebaseerd op het verloop van de gemiddelde kwaliteitskosten wanneer de perfecte kwaliteit dicht wordt genaderd. Het karakter van het verloop is dus eerst vrijwel constant tot licht stijgend; daarna sterk stijgend ${ }^{21}$.

Figuur 3.1. geeft de iso-winstcurven van de geschetste situatie. Als de optimale mix van $\mathrm{Q}$, en $\mathrm{Q}$, nog niet is bereikt, zoals in punt $\mathrm{A}$, kan nog een hogere winst worden gehaald door de kwaliteit $Q_{a}$ en $Q_{s}$ zodanig te verbeteren dat de nieuwe positie $B$ wordt bereikt. Als bijvoorbeeld technische belemmeringen overwonnen zijn, kan uiteindelijk in punt $C$ de optimale mix bereikt worden en is de winst maximaal. Een onderneming kan kiezen uit én of een aantal dimensies om de kwaliteit te verbeteren. Het resultaat van een dergelijke verbetering is afhankelijk van de marginale kosten en marginale opbrengsten.

Zie woor een afleiding bijlage $\mathrm{B}$.

De uitgangssituatie (het beginpunt) wordt dlus gekenmerkt door minimalle of nagenoeg minimale gemiddelde kwraliteitskosten (vergelijk het verloop van gemiddelde kwaliteitskostencurves in de kwaliteitszorgliteratuur (Lundvall \& Juran 1974, Van Grinsven 1984)). 
Figur 3.1.: Tso-wingtcurven bij verachillende combinaties van kwaliteitseigenschappen.

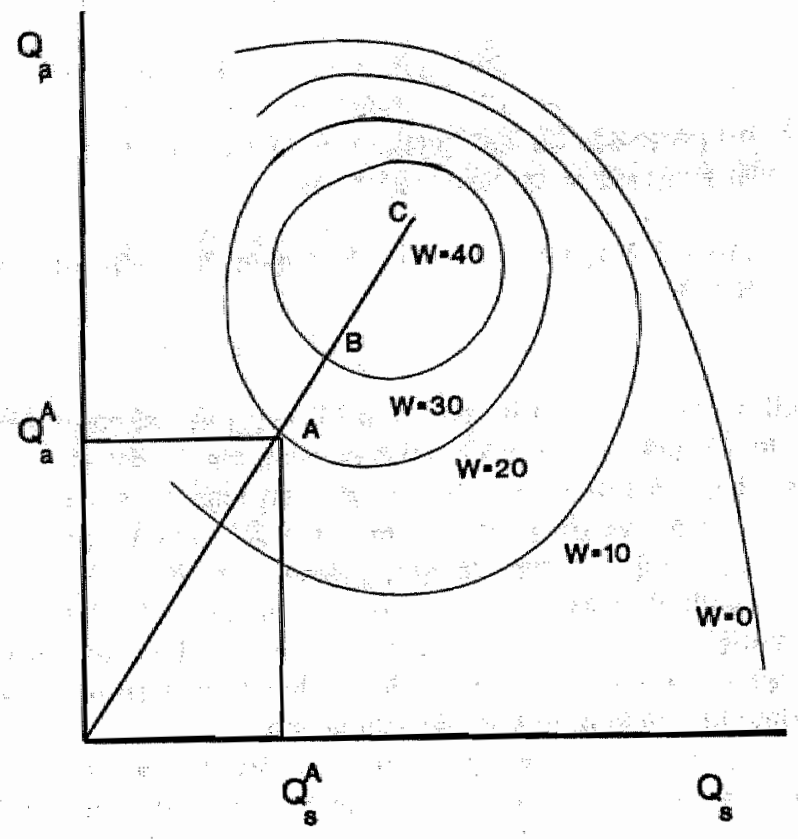

\subsubsection{Soorten $P K V$ 'n volgens Abbott}

Abbott (1955) maakte, zoals reeds in het vorige hoofdstuk is aangegeven, onderscheid tussen horizontale, verticale en innovatieve kwaliteitsverbeteringen. Zijn conclusie was dat in werkelijkheid kwaliteitsverbeteringen niet vaak door én van deze soorten zijn te beschrijven. Vaak is het een $\mathrm{mix}$ van verbeteringen. Horizontale-innovatieve veranderingen zijn belangrijker geworden de laatste jaren. Bijvoorbeeld, nieuwe automodellen hebben in het algemeen ook enkele nieuwe technische kenmerken. Hybride produktkwaliteitsverbeteringen zijn vaker regel dan uitzondering (Koutsoyiannis 1982; p. 11-12).

\subsubsection{Marketing-tekstboeken en soorten PKV'n}

In de meeste marketing-tekstboeken wordt een drietal typen produktmodificaties onderscheiden (Kollat, Blackwell \& Robeson 1972, Kotler 1980, McCarthy \& Perrault 1984, Kotler \& Armstrong 1987, Lusch \& Lusch 1987, Leeflang 1987, Pride \& Ferrell 1989):

1. Kwaliteitsmodificaties; de modificaties die gerelateerd zijn aan betrouwbaarheid en duurzaamheid van het produkt, ofwel het beter inspelen op de functie die het produkt voor afnemers kan vervullen.

2. Toepassingsmodificaties; de modificaties die nieuwe karakteristieken toevoegen aan het produkt, zoals veiligheid, veelzijdigheid en gemak.

3. Vormgevingsmodificaties; de modificaties die de esthetische aantrekkelijkheid van het produkt betreffen. 
Een produktmodificatie houdt in een niet-fundamentele verandering van én of meer produktkenmerken. Als er vanuit wordt gegaan dat een produktmodificatie een verbetering en geen verslechtering inhoudt dan kunnen alle drie genoemde typen produktmodificaties gekenmerkt worden als produktkwaliteitsverbetering. Het kwaliteitsbegrip dat in ons onderzoek wordt gehanteerd, is breder dan het kwaliteitsbegrip dat wordt bedoeld bij de kwaliteitsmodificaties, genoemd onder het type 1. De drie genoemde typen kunnen derhalve worden aangemerkt als verschillende soorten PKV'n.

\subsubsection{Indeling in soorten PKV'n volgens Garvin}

Vanuit de optiek van de klant $k$ an een aantal velden worden aangegeven, waarop ondernemingen met hun produktkwaliteit kunnen concurreren. Achtereenvolgens worden onderscheiden (Garvin 1984b; p. 42):

"Performance, Features, Reliablity, Conformance, Durability, Servicenbility, Aesthetics en Penceived Quality".

Bij deze acht begrippen kan de volgende toelichting gegeven worden:

1. "Performance"; de fysieke primaire kenmerken van het produkt.

2. "Features"; de "toeters en bellen" van het produkt.

3. "Reliability"; de betrouwbaarheid.

4. "Conformance"; de overeenstemming met de specificaties.

5. "Durability"; de duurzaamheid.

6. "Serviceability"; de service-vriendelijkheid.

7. "Aesthetics"; de afwerking en "schoonheid".

8. "Perceived quality"; de reputatie en ongrijpbare produktkenmerken.

Vervolgens betoogt Garvin dat zorgvuldig én of enkele velden uitgekozen moeten worden, waarmee men dan kan gaan concurreren, De categorieën overlappen elkaar. enigszins. Zo is duidelijk dat de achtste categorie "perceived quality" niet los gezien kan worden van de andere categorieën. Voor duurzame goederen lijkt deze indeling evenwel bruikbaar. Dit levert een bruikbare indeling op als het gaat om onderscheid te maken tussen verschillende soorten PKV' $n$.

\subsubsection{Andere aanzetten tot een indeling in soorten PKV'n}

Thams (1984) maakt onderscheid in een aantal categorieën van kwaliteitsproblemen die kunnen voorkomen bij produkten van ondernemingen, namelijk problemen ten aanzien van de:

1. Basiskwaliteit.

2. Functionele kwaliteit.

3. Perifere kwaliteit.

4. Business-ontwikkeling.

De basiskwaliteit heeft betrekking op de produkteigenschappen die moeten voldoen aan een bepaalde standaard. De functionele kwaliteit heeft betrekking op de 
toepassingsmogelijkheden en de mate van klantgerichtheid. Een voorbeeld is de manier van presenteren van een produkt, verpakking, informatie over levering of reparatie. De perifere kwaliteit heeft te maken met de factoren die buiten de dienstverlening van ondernemingen liggen maar wel belangrijk zijn voor het naar tevredenheid uitvoeren van de dienstverlening, zoals de beschikbaarheid wan kennis en middelen. Als laatste noemt Thams de business-ontwikkeling die plaatsvindt als nieuwe produkten of oplossingen worden ontwikkeld om tegemoet te komen aan de wensen van klanten. Thams $(1984 ; \mathrm{p}$. 9) signaleert naar aanleiding van een steekproef uit door ondernemingen ervaren problemen dat $44 \%$ (het hoogste percentage) van die problemen betrekking had op de functionele kwaliteit. De perifere kwaliteit en de businessontwikkeling zijn nauwelijks te relateren aan PKV'n. De perifere kwaliteit heeft te maken met kennis en middelen ten behoeve van het produktieproces. Business-ontwikkeling heeft betrekking op nieuwe produkten. De twee andere categorieên zijn wel bruikbaar als indeling voor verschillende soorten PKV'n.

Kwaliteitsverbeteringen kunnen, volgens Kyj (1987), betrekking hebben op het fysieke produkt maar ook op de "customer service", met andere woorden op de dienstverlening rond het produkt. Vaak zijn binnen de onderneming verschillende functionele eenheden verantwoordlelijk voor deze kwaliteitsaspecten. Onder "customer service" valt onder andere de administratieve afhandeling, het transport en de aflevering, en de after-sales service, naast de contacten met de afnemers in het algemeen. Het fysieke produkt heeft te maken met het produkt zoals dit door de produktie-afdeling is afgeleverd. Deze indeling zou eveneens gebruikt kunnen worden bij een nadere differentiatie naar soorten PKV'n.

Ondanks het feit dat meerdere indelingen bruikbaar zouden kunnen zijn om soorten PKV'n te onderscheiden, lijkt de indeling van Garvin het meest geschikt. Garvin levert de meest verfijnde indeling en de beschrijvingen van elke afzonderlijke categorie is uitgebreid en gedetailleerd. Op basis van deze beschrijvingen kunnen de verschillende soorten PKV'n wellicht goed van elkaar worden gescheiden. Verder is de indeling van Garvin eenvoudig te relateren aan de eerder genoemde fundamentele benaderingen van kwaliteit (produktie-, produkt- en gebruikergericht).

\subsection{De reacties van concurrenten}

In deze paragraaf wordt getracht aan de hand van de resultaten van theorievorming en empirisch onderzoek verder zicht te krijgen op de reacties van concurrenten in geval van PKV"n. Eerst zal in paragraaf 3.3.1, aandacht gegeven worden aan de formele microeconomische benadering. Daarna zullen in paragraaf 3.3.2. enkele empirische studies behandeld worden.

\subsubsection{Micro-economische benadering van reacties van de concurrent}

De conclusies, op basis van de formele analyses ${ }^{22}$, zijn dat de onderneming die een PKV doorvoert rekening dient te houden met concurrentiële reacties in de vorm van een PKV 
en/of een reactie in de vorm van één of meer van de andere marketing-mix instrumenten. Gegeven het streven naar winstmaximering, moet de PKV van de initiator zodanig zijn dat er geen vergelijkbaar sterke, of sterkere reacties van de concurrentie plaatsvindt. Bij het doorvoeren van PKV'n dient dus met de aard en sterkte van de reactie rekening worden gehouden.

Een belangrijke bijdrage in dit verband is het theoretische deel van de studie van Lambin, Naert \& Bultez (1975). Lambin, Naert \& Bultez maken onderscheid tussen een reactie met hetzelfde marketing-mix instrument en een reactie met meer dan eén marketing-mix instrument. Het eerste geval wordt omschreven als een enkelvoudige reactie, het tweede als een meervoudige reactie. In onze studie," waarin PKV'n centraal staan, wordt dan ook op analoge wijze onderscheid gemaakt tussen reacties met eveneens een PKV en reacties met een PKV naast veranderingen in eén of meer andere marketing-mix instrumenten. Verder maken deze auteurs onderscheid tussen een tweetal marktvormen (monopolie en oligopolie), twee marktgroei-situaties (stabiele vraag en groeiende vraag) en drie reactieintensiteiten (geen reactie, enkelvoudige reactie, meervoudige reactie). Vervolgens leiden Lambin, Naert \& Bultez (1975; pp. 106-115) een algemeen geldig model af, dat kan worden aangepast als een specifieke situatie zich voordoet. Bijvoorbeeld bij afwezigheid van een concurrentiële reactie vervalt de matrix van reactie-parameters. Het model, dat in concept uitgaat van eéndimensionale produktkwaliteit, kan eenvoudig uitgebreid worden naar een multidimensionale produktkwaliteit.

PKV'n kunnen zowel door de afnemers als door de concurrentie opgemerkt worden. Het wel of niet opmerken van PKV'n door concurrenten heeft uiteraard consequenties, zowel voor de initiator zelf als de concurrent. Als de PKV niet wordt opgemerkt hoeft de initiator geen reactie te verwachten en is het voordelig, wanneer de marginale opbrengst van de PKV groter is dan de marginale kosten, vanwege de sterker geworden relatieve kwaliteitspositie. Voor de concurrent kan dat nadelig zijn vanwege de verzwakking van de relatieve kwaliteitspositie. Wanneer de PKV daarentegen door de concurrentie wel wordt opgemerkt, heeft de concurrentie de mogelijkheid te reageren. De initiator loopt het risico dat de reactie van eên of meer concurrenten de verbeterde relatieve kwaliteitspositie geheel of gedeeltelijk teniet kan doen.

\subsubsection{Enkele empirische resultaten ten aanzien van concurrentiële reacties}

De concurrentie reageert in veel gevallen op een PKV. Dit blijkt uit studies van Nicholls (1951) en Booy (1965) en uit de resultaten van ons pilot-onderzoek ${ }^{23}$. Booy (1965; p. $147)$ concludeert in zijn studie van enkele zeer van elkaar verschillende oligopoloîde bedrijfstakken (de sigaretten-industrie, conservenblik-industrie, de auto-industrie en de zeep-industrie) dat kwaliteitsverbeteringen van produkten veel navolging ondervinden, en wel doorgaans op vrij korte termijn. Uit deze studies concluderen we dat bedrijven kunnen reageren op PKV'n door een soortgelijke kwaliteitsverbetering door te voeren (Booy spreekt van "navolging"). 
In een ander type studie, namelijk op basis van longitudinaal econometrisch onderzoek, wordt ook aandacht besteed aan het effect wan de inzet van marketing-mix instrumenten en de reacties van de concurrenten op het marktaandeel.

Studies op basis wan dergelijke modellen hebben geleid tot cen aantal antwoorden op de vraag of en welke concurrentielle reacties plaatsvinden op inzet van marketing-mix instrumenten (Wildt 1974, Lambin, Naert \& Bultez 1975, Hanssens 1980, Gatignon 1984, Alsem, Leeflang \& Reuyl 1986 1989, Carpenter, Cooper, Hanssens \& Midgley 1988, Plat 1988 en Leeflang \& Wittink 1990). De studies van Wildt (1974), Hanssens (1980) en Lambin, Naert \& Bultez (1975) zijn de enige waarin expliciet een specificatie is opgenomen van het marketing-mix instrument produkt(kwaliteit) Deze specificatie kan ons inziens bij benadering dienen als een indicator voor een PKV. Wildt gebruikt hiervoor het percentage nieuwe produkt-varieteiten in het totale produktpakket. Hanssens specificeert het antal vluchten van vliegmaatschappijen. Lambin, Naert \& Bultez gebruiken het subjectieve oordeel van experts van én van de betrokken ondermemingen over de kwaliteit van het produkt. De overige studies gaan uit van verschillende andere marketing-mix instrumenten.

Wildt's onderzoek richt zich op de markt voor een consumptiegoed dat vila de detailhandel wordt verkocht. Op basis van de schattingen in de econometrische modellen kan worden geconcludeerd dat het ondememingsaandeel van nieuwe produktvariëteiten in de branche (hier als benadering gebruikt van PKV'n) een statistisch significant positief verband laat zien met het marktaandeel. PKV'n van concurrenten daarentegen hebben een significant negatieve invloed op het marktaandeel. Voorts blijkt dat er significant positieve verbanden gesignaleerd worden tussen PKV'n en reclame-uitgaven van concurrenten. De reclame-uitgaven van de reagerende concurrenten worden gemiddeld 4 maanden na de PKV van de initiator verhoogd.

Uit Hanssens' onderzoek bleek dat het aantal vluchten (kwaliteit) van concurrenten met elkaar samenhangen. Met andere woorden is er enig bewijs dat concurrenten op elkaar reageren (en navolgen) met kwaliteitsaspecten. Concurrentiële reacties op veranderingen van het aantal vluchten met behulp van reclame (meervoudige reacties) kunnen niet worden bewezen.

Lambin, Naert \& Bultez voeren hun onderzoek uit in een markt voor een duurzaam consumptiegoed. Het goed bevindt zich in de verzadigingsfase van de produktlevenscyclus. Er bestaat dus een hoge graad van afhankelijkheid tussen de grootste drie concurrenten die samen $90 \%$ van de markt bestreken. Het resultaat van hun modelschattingen houdt onder andere in dat:

1. Een sterke reactie plaatsvindt wanneer door de marktleider de prijs of de kwaliteit wordt gewijzigd.

2. Sterke aanwijzingen naar voren komen voor meervoudige concurrentiële reacties.

3. Op inzet van verscheidene marketing-mix instrumenten gereageerd wordt met kwaliteitsaanpassingen.

In een poging deze resultaten gevonden in specifieke consumentenmarkten, te generaliseren, kan wellicht voorzichtig worden geconcludeerd dat produktkwaliteil een belangrijke rol in het concurrentieproces speelt, en dat met name ook meervoudige reacties voorkomen (in twee van de drie genoemde empirische onderzoeken). 
In dit verband blijkt dat de reactietijd van concurrenten afhankelijk is van het gekozen instrument. In het algemeen is een snelle reactie mogelijk met de prijs en in de promotiesfeer (Brems 1966a; p. 154, Koutsoyiannis 1982; p. 5). Het aanpassen van de kwaliteit van produkten (PKV) vergt in de regel meer tijd (Kotler 1984; p. 69).

Of bedrijven reageren met een kwaliteitsverbetering is afhankelijk van een aantal voorwaarden:

1. De PKV moet opgemerkt zijn.

2. De organisatie-structuur moet erop berekend zijn dat er een reactie wordt doorgevoerd.

3. De technische mogelijkheden om te reageren moeten aanwezig zijn.

4. De financiële middelen moeten beschikbaar zijn (zie voor dit argument ook Scherer 1980; p. 375).

Vaak nemen bij PKV'n technische en financiële beslissingen enige tijd in beslag, waarna de daadwerkelijke uitvoering nog plaats moet vinden. De snelheid van reageren is bovendien afhankelijk van het antwoord op de vraag hoe dicht men het optimale kwaliteitsniveau al is genaderd. Brems (1966a; p. 152) concludeert:

"....the optimal product quality is the higher, the tardier is rival response".

Hoe dichter men bij het optimale kwaliteitsniveau is aangeland, des te trager is de concurrentiële reactie.

Uit deze empirische studies kan worden geconcludeerd dat PKV'n een belangrijke rol spelen in het concurrentieproces en dat reacties van concurrenten te verwachten zijn. Dit hoeft niet altijd plaats te vinden met behulp van hetzelfde marketing-mix instrument, maar kan ook door één of meer andere marketing-mix instrumenten plaatsvinden. Met het prijsen promotie-instrument is een onderneming sneller in staat te reageren dan met produktof distributie-instrumenten. De tijd om te reageren wordt uiteraard bepaald door het wel of niet opmerken van de PKV bij de concurrent, maar ook door de flexibiliteit van de organisatie, de technische mogelijkheden en de financiële middelen van de organisatie.

\subsection{Parallellen met onderzoek uit de "industriële economie" en econometrische marketing modellering}

\subsubsection{Algemeen}

Er is binnen de "industriële economie" veel onderzoek verricht naar de reacties van ondernemingen bij het binnentreden van de markt door een nieuwe concurrent. Wij achten dit in vrij sterke mate een vergelijkbare problematiek met de vragen rond concurrentiële reacties op PKV'n. Deze theorieen en empirische onderzoeksresultaten kunnen ook van belang zijn bij bestudering van PKV'n. Immers, ook nu wijzigen de concurrentieverhoudingen zich. In plaats van markttoetreding met een kwalitatief beter en/of goedkoper produkt gaat het in ons onderzoek om kwaliteits-verbeteringen van bestaande produkten. Deze kunnen evenzeer reacties uitlokken, omdat impliciet de prijs/kwaliteit verhouding van het produkt wordt gewijzigd ten opzichte van die van de concurrenten. Het marketing-mix instrumentarium waarmee andere ondernemingen 
kunnen reageren is evenwel in beide gevallen hetzelfde.

Een aantal van deze studies zal nu worden besproken. Achtereenvolgens wordt aandacht besteed aan de studies en conclusies van Biggadike (1979), Yip (1982), Robinson (1988) en Gatignon, Anderson \& Helsen (1989).

De relatie tussen reactie van de concurrentie, toetredingsstrategie en marktstructuur is empirisch onderzocht door Biggadike (1979). Biggadike geeft een beschrijving van de wijze waarop de concurrentiële reactie werd gemeten, en formuleert enkele hypothesen over de aard en intensiteit van de reactie. Tenslotte worden deze hypothesen door hem getoetst, evenals de implicaties van de reacties voor het resultaat van de onderneming die de markt binnentreedt. In verband met de genoemde parallellen en de originaliteit van Biggadike's onderzoek, zullen zijn werkwijze en bevindingen verderop in dit hoofdstuk worden weergegeven, waarna een aantal vergelijkbare hypothesen voor ons onderzoek zal worden geformuleerd. Op deze plaats is het voldoende te vermelden dat Biggadike (1979) 37 nieuw produktintroducties onderzocht en concludeerde uit antwoorden die afkomstig waren van de bedrijven, die de nieuwe produkten introduceerden, dat in iets meer dan de helft van het aantal gevallen de concurrentie reageerde.

Yip (1982) concludeerde uit zijn studie naar toetredingen op de markt door ondernemingen dat door $10-20 \%$ van de reeds op de markt opererende ondernemingen werd gereageerd. Wanneer deze toetreding gepaard ging met een produktkwaliteit hoger dan het marktgemiddelde, dan werd door $30 \%$ van de ondernemingen gereageerd. Een toetreding tot een markt gaat gepaard met een reactie van een klein gedeelte van de reeds op de markt aanwezige ondernemingen. Meer ondernemingen reageren wanneer de "nieuw toetredende kwaliteit" hoger is dan gemiddeld.

Robinson (1988) concludeert op basis van 115 toetredingen tot oligopoloilde markten dat de typische reactie geen reactie of eén enkelvoudige reactie is. Voorts merkt hij op dat het vrijwel niet voorkomt dat toetreders een reactie tegenkomen die alle elementen van de marketing-mix omvat. Op basis van het geformuleerde onderzoeksmodel slaagt Robinson erin om de intensiteit van de reactie te verklaren. Hij slaagt er echter niet in de aard van de reactie te verklaren. In groeimarkten worden intensieve reacties gevonden. Tot slot is de reactie-intensiteit afhankelijk van het type toetreding. Toetredingen op grote schaal hebben intensieve reacties tot gevolg in het eerste en tweede jaar na de toetreding. In het eerste jaar na toetreding vinden er nauwelijks reacties plaats op innovatieve toetredingen. Echter in het tweede jaar zijn de reacties intensief. De reeds op de markt aanwezige ondernemingen hebben tijd nodig om hiervoor een adequate strategie te formuleren. Vervolgens blijkt dat intensievere reacties plaatsvinden, wanneer de aanwezige marktleider sterk afhankelijk is van de betreffende markt. Tot slot concludeert Robinson dat de gemiddelde reactie-intensiteit niet verschilt tussen de consumentenmarkt en industriële markt.

Gatignon, Anderson \& Helsen (1989) komen tot de conclusie dat richtlijnen voor concurrentiêle reacties vaak tot tegenstrijdige aanbevelingen leiden, en dat de normatieve modellen waarop deze richtlijnen zijn gebaseerd, nog niet empirisch onderzocht zijn. Meer specifiek blijkt uit hun empirisch onderzoek dat concurrenten reageren met de "goede" instrumenten; dat zijn marketing-mix variabelen waarvoor de marktrespons relatief elastisch is (vergelijk Kotler \& Singh 1981). 
De conclusies uit de genoemde studies kunnen in een zestal punten worden samengevat:

1. In de genoemde studies wordt wel de reactie-index, de intensiteit van de reactie door de reeds op de markt aanwezige concurrenten, verklaard. De aard van de marketing-mix reacties kon door deze empirische onderzoeken nog niet worden verklaard.

2. De empirische resultaten worden gebaseerd op een mengsel van industriële en consumentenmarkten. Er wordt geen onderscheid gemaakt omdat, zoals Robinson 1988; p. 380) concludeert uit de analyses van de reactie-intensiteit:

"Mean reactions are not influenced by the distinction between consumer and industrial goods".

3. De typische reactie op een markttoetreding is geen reactie of een reactie met én marketing-mix instrument.

4. De reactie van concurrent vindt plaats met de "goede" instrumenten: marketingmix variabelen waarvoor de marktrespons relatief elastisch is.

5. De reactie-intensiteit van de concurrentie is afhankelijk van 1) de soort toetredingsstrategie, 2) de mate waarin de aanwezige marktleider afhankelijk is van de betreffende markt en 3) de marktgroei.

6. Als in de diverse empirische onderzoeken de verhouding industriële markt versus consumentenmarkt wordt berekend, blijkt dat het grootste deel van de respondenten zich in industriële markten bevindt (zie tabel 3.1).

Echter, wanneer de resultaten geillustreerd worden met voorbeelden, blijken deze (case-studies) meestal niet over de industrièle markt te gaan. De aangehaalde voorbeelden gaan vrijwel zonder uitzondering over consumenten-produkten, zoals geneesmiddelen, credit cards, tandpasta, wijncoolers, ballpoints en huishoudtextiel.

Tabel 3.1.: De verhouding tussen industriële markt en consumentenmarkt in een drietal empirische studies naar reactiegedrag ten aanzien van markttoetredingen.

\begin{tabular}{|c|c|c|c|}
\hline Studie & Totaal aantal. & Percentage van de & igen: \\
\hline & ondernemingen & Consumentenmarkt & Indwstriële markt \\
\hline Biggadike (1979) & 40 & $15 \%$ & 85 \\
\hline Yip (1982) & 31 & $19 \%$ & $81 \%$ \\
\hline Robinson (1988) & 115 & $25 \%$ & $75 \%$ \\
\hline
\end{tabular}

\subsubsection{Het meten van de intensiteit van de concurrentiële reactie}

Een reactie heeft plaats gevonden als na de toetreding de concurrenten hun marketing-mix ten opzichte van de mix van voor de toetreding gewijzigd hebben. Daarbij werd voor reacties op toetredingsstrategieën een termijn van maximaal twee jaar gehanteerd. Deze termijn werd gehanteerd om zoveel mogelijk te voorkomen dat over reacties gerapporteerd zou worden die het rechtstreekse gevolg zouden zijn van andere aanleidingen dan de 
betreffende toetreding. Bovendien werd afgezien van eventuele anticipatie van reeds op de markt aanwezige concurrenten, voorafgaand aan de toetreding.

Biggadike (1979) stelde een index samen, door middel van een waarde die werd toegekend aan de intensiteir van de reactie van elk van de instrumenten afzonderlijk. Deze intensiteit kon variëren tussen 0 (geen reactie met het betreffende instrument) en 6 (maximale reactie; bijvoorbeeld voor prijs een prijsdaling van meer dan $25 \%$ ), met tussenstappen van twee punten. Ondernemingen konden maximaal vijf instrumenten aangeven waarmee men reageerde; de marketing-mix instrumenten produkt, prijs, distributie, marketinguitgaven (=uitgaven aan verkoop, reclame en promotie) en capaciteitsveranderingen.

Robinson (1988) berekent de reactie-intensiteit door aan elke reactie met een marketingmix instrument de waarde 1 toe te kennen. Aangezien hij 4 marketing-mix instrumenten onderscheidt, kan de reactie-intensiteit dus maximaal de waarde 4 opleveren. De reactieintensiteit kan ook negatieve waarden aannemen als de reactie een "hulp" is voor de toetreder. Een waarde van -1 wordt bijvoorbeeld toegekend aan een reactie door middel van het verhogen van de prijs. Negatieve waarden komen in het empirisch onderzoek van Robinson echter bijna niet voor. Dat op deze wijze geen rekening is gehouden met de intensiteit van de marketing-mix instrumenten afzonderlijk (bijvoorbeeld prijsdaling van $1 \%$ of $10 \%$ ) is volgens Robinson voor de economische betekenis van de analyses niet van belang. Bovendien heeft de methode het voordeel dat ze eenvoudig uit te leggen is.

\subsubsection{Hypothesen omtrent concurrentiële reacties uit de literatuur}

De (verwachte) reactie van de concurrent is een belangrijke overweging bij beslissingen van het management in oligopoliesituaties, omdat het beperkte aantal concurrenten zorgt voor strategische interdependenties. Bij onderzoek naar reacties is het een probleem dat de reactie kan variëren al naar gelang de subjectieve oordelen en percepties van concurrenten, hun attitudes en risico's, en hun inschattingen van toekomstige marktkansen. Needham $\left(1969^{24}\right)$ concludeert dan ook dat:

$$
\text { "...the exact nature of the reaction.....cannot be determined by a priori reasoning". }
$$

Dit probleem wordt in het gebruikelijke oligopolie-onderzoek altijd omzeild door mechanistische vooronderstellingen ten aanzien van het gedrag van de toetreder en van de bestaande concurrent. Het Sylos postulaat (Bain 1956, Sylos-Labini 1962, Modigliani 1958) stelt dat potentiële toetreders uit moeten gaan van een handhaving van de produktie, en een verlaging van de prijs door de bestaande concurrenten. Er wordt geen reden voor gegeven, afgezien van het feit dat het veilig lijkt uit te gaan van de meest ongunstige reactie van bestaande concurrenten. Er zijn tal van varianten ontwikkeld, die met name ook ingaan op het door de toetreder gepercipieerde gedrag van de bestaande concurrentie, en de mate waarin zo'n toetreder daar dan rekening mee houdt.

Marris (1968) onderzocht de invloed van groei van de totale afzetmarkt op het reactiegedrag van bestaande concurrenten. De reactie zou minder intensief zijn in een groeimarkt, omdat de toetreder dan niet de verkopen van bestaande ondernemingen verdringt, om een aanvaardbaar marktaandeel te verkrijgen. Daarentegen neemt een toetreder in een 
markt met een lage groel een deel van de bestaande afzet voor zijn rekening. Marris (1968, p. 194) veronderstelt:

"In static markets the conflict situation is necessarilly intense... [An entrant] may be compelled to fight a war in which one or mone producers is driven out to make room for him".

Omdat de bestaande concurrentie zich niet realiseent dat het marktaandeel terugloopt (de absolute verkopen in een groeimarkt kunnen immers nog stijgen) vindt een vertraagde prijsreactie plaats, resulterend in een "peace-price" een prijs waarbij de marktaandelen constant blijven.

Alemson (1969) heeft kritiek geuit op deze zienswijze, en betoogt dat:

1. De bestaande concurrentie wel degelijk reageert omdat de toetreding als een bedreiging wordt gezien.

2. De ondernemingen wel degelijk beschikken over informatiesystemen die inzicht geven in het marktaandeel en zo in de actuele concurrentiepositie. Bovendien is het marketing-beleid vaak gedefinieerd in termen van marktaandelen.

Naast de groei van de markt en het marktaandeelverlies van de bestaande concurrenten is het volgens Biggadike (1979) ook belangrijk rekening te houden met de soort toetredingsstrategie (bijvoorbeeld een agressieve prijsstrategie of een superieure kwaliteit) die door de toetreder gekozen is.

Marris veronderstelt slechts een reactie met het marktinstrument prijs, resulterend in een situatie met stabiele marktaandelen en prijzen. Het lijkt echter onwaarschijnlijk dat concurrenten in groeimarkten slechts met de prijs concurreren en elkaar vinden in een stabiele verdeling van de markt. Concurrentie in een groeimarkt heeft bijvoorbeeld ook betrekking op de snelle verandering van de produktietechnologie, produktontwerp en distributiekanalen. Concurrentie vindt plaats op (vrijwel) alle elementen van de marketingmix. Het lijkt er op dat een situatie zoals die door Marris is omschreven, slechts dan plaatsvindt wanneer de groei tendeert naar nul. De door Marris verwachte stabiele situatie vindt dus pas plaats als niet meer voldaan is aan de groeimarktconditie, die als uitgangspunt voor deze redenering heeft gediend.

Op basis van bovenstaande overwegingen komt Biggadike (1979; p. 177) tot een aantal hypothesen, die hij vervolgens toetst. Twee van deze hypothesen luiden:

1. "Entrants into growth markets will report a lower index of reaction than entrants into mature markets".

2. "Reaction will be higher as incumbents' share loss between pre- and postentry periods is larger".

Biggadike's empirisch onderzoek bevestigt de eerste hypothese niet. Het ziet ernaar wit dat er in de verzadigingsfase door de concurrentie minder intensief wordt gereageerd. Robinson (1988) komt eveneens tot de conclusie dat tussen marktgroei in de branche en de reactie-intensiteit een significant positief verband bestaat.

Ook de tweede hypothese wordt niet bevestigd. Biggadike concludeert dat markttoetredingen op zeer grote schaal minder intensieve concurrentiële reacties teweeg brengen. Het wordt door de reeds aanwezige concurrenten als zinloos gezien om op zeer sterke toetreders te reageren. De korte termijn kosten die met een dergelijke reactie gepaard zouden gaan kunnen boven de lange termijn winsten uitstijgen. Robinson (1988) vindt een enkele aanwijzing dat er inderdaad sprake is van een inverse U-worm van de reactie- 
intensiteit. Met andere woorden, naarmate de marktaandeelwinst van de toetreder groter is, stijgt de reactie-intensiteit; bij een zeer grote marktaandeelwinst is de reactie-intensiteit weer lager.

Gezien vanuit het effect van de concurrentïle reactie op het resultaat van de markttoetreding komt Biggadike tot de eindconclusie dat de concurrentiële reactie niet groot was en dat het resultaat (ROI en marktaandeel) van de onderneming er niet door werd beïnvloed. De ROI blijkt iets hoger te zijn bij markttoetreders die geen concurrentiële reactie bemerken (betrouwbaarheid: $p=0,18$ ). Het tegengestelde geldt voor het marktaandeel. Markttoetreders die geen concurrentiële reactie bemerken veroveren een lager marktaandeel dan markttoetreders met een concurrentiële reactie.

Schema 3.2.: Empirisch onderzoek ten aanzien van PKV'n, markttoetredingen en reacties van concurrenten.

Ondlerwerp van een markt en aantal markten stidie:

Anallyse:

Typische opzet wan de analyse:

1) methode:

2) actoren:

3) data:

4) bron:

Empirisch onderzoek van:

1) effecten van veranderingen in het marketingmix instrument produlkt

(en tuidere instrumenten)

2) markttoetredingen (nieuw produkt) longitudinatal econometrisch onderzoek

de concurrenten met het grootste marktaandeel (samen goed voor $90 \%$ van de markt)

(scanner)data over een bepaalde periodle

objectief/feitelijko

verslaglegging

Wildt (1974)

Lambin, Naert \& Bultez

(1975)

Hanssenis (1980)

Gatignon, Anderson \&

Helsen (1989) cross-sectie anallyse

de initiator en de belang-

rijkste concurrent(en)

(PIMS)data over acties (PKV'n en markttoetredingen) en door initiērende ondernemingen gerapporteerde reactie(s) van concurrent(en)

subjectief/percepties \& meningen van managers

Lemmink \& Kasper (1990)

Lemmink (deze studie)

Biggadike (1979)

Yip (1982)

Robinson (1988) 


\subsubsection{Parallellen met reacties van concurrenten op $P K V$ 'n en conclusies}

Het empirisch onderzoek naar reacties op markttoetredingen van reeds op de markt aanwezige concurrenten vindt plaats zowel door middel van longitudinaal econometrisch onderzoek op basis van eén markt als door cross-sectioneel onderzoek op basis van een aantal markttoetredingen. Dit cross-sectioneel onderzoek is gebaseerd op door de markttoetreders gerapporteerde reacties van reeds op de markt aanwezige concurrenten. Reacties ten aanzien van PKV'n zijn in het verleden onderzocht door longitudinaal econometrisch onderzoek. In ons onderzoek naar PKV'n staat de cross-sectie benadering centraal. Daarbij wordt gebruik gemaakt van hypothesen en inzichten uit de genoemde empirische onderzoeken. Samenvattend kunnen de genoemde onderzoeken in schema 3.2. worden ondergebracht.

Blijkbaar is met behulp wan econometrisch onderzoek nawwkeurig het reactiepatroon in markten vast te stellen en daarop aansluitend analytisch de resultaten voor de ondernemingen te berekenen. Echter, om tot algemeen geldige uitspraken te kunnen over het reactiegedrag en uiteindelijke resultaat zijn meer gegevens van belang, vanwege de situationele factoren die voor verschillende markten een rol spelen. Zo kan de marktgroei of de marktstructuur van belang zijn. Biggadike (1979; p. 193) komt dan ook tot de conclusie dat:

"Obviously, explaining business performance is a multiwariate problem, but I hawe not been able to formally do that".

In het door ons in het volgende hoofdstuk ontwikkelde model en in de empirische uitwerking zal getracht worden rekening te houden met het multivariate karakter van het onderzoek.

Op basis van de theoretische uitgangspunten van deze studies en de bevindingen van de empirische toepassingen werd reeds in dit hoofdstuk een aanzet gegeven tot een aantal hypothesen. De exacte hypothesen zullen na de specificatie van het model in het volgende hoofdstuk worden gegeven. Kort samengevat betreffen de globale aanzetten tot hypothesen voor ons onderzoek de volgende onderwerpen/probleemgebieden:

$A^{25}$. Een beschrijving van de redenen (aanleidingen) voor het verbeteren van de produktkwaliteit.

B.a) Een beschrijving van de reacties van de belangrijkste concurrent, naar soorten reacties. Daarbij wordt aandacht besteed aan de empirische resultaten van de genoemde onderzoeken.

b) Naast de soort reacties kan de intensiteit van de reacties op PKV'n geanalyseerd worden. De hypothesen ten aanzien van reacties op PKV' $n$ zijn dan af te leiden uit de bovenstaande analyses omtrent markttoetredingen omdat een vergelijkbare redenering kan worden gegeven. De hypothesen ten aanzien van kwaliteitsverbeteringen en de intensiteit van de reactie (reactie-index) luiden dan:

1. De reactie-index is lager voor markten met een hoge groei dan voor markten met een lage groei.

Bij de aanzetten A. $t / \mathrm{m}$ D. wordt eveneens onderscheid gemaakt tussen verschillende soorten PKV"n, zoals aangegeven in paragraaf 3.2.. In hoofdstuk 4 bij het formuleren van de hypothesen wordt hieraan meer andacht besteed. 
2. De reactie-index is groter naarmate het marktaandeelverlies van concurrenten, naar aanleiding van de PKV groter is.

c) Een inventarisatie van de snelheid van de reacties door concurrenten.

C. Het effect van de concurrentiele reactie op het resultaat van de PKV.

D. De relatie tussen omgevingsvariabelen (produktlevenscyclus, marktstructuur) en de onder $\mathrm{A} t / \mathrm{m} C$ genoemde analyses. Bijvoorbeeld de relatie tussen de fase in de produktlevenscyclus en de intensiteit van de reactie. 


\section{Produktkwaliteitsverbeteringen en reacties van concur- renten: model en hypothesen}

In dit hoofdstuk zal eerst een model worden besproken dat gehanteerd kan worden voor het beschrijven en analyseren van produktkwaliteitsverbeteringen en concurrentiële reacties. Daarna zal een aantal hypothesen worden geformuleerd op basis van de conclusies van het literatuuronderzoek uit hoofdstuk 3 en enkele aanvullende overwegingen.

Eerst wordt in paragraaf 4.1. het uitgebreide model toegelicht. Daarna wordt in paragraaf 4.2. op basis van het uitgebreide model een beperkter model gepresenteerd met slechts die onderlinge relaties waarover hypothesen zijn te formuleren. Vervolgens worden die onderzoekshypothesen gepresenteerd en toegelicht.

\subsection{Model voor PKV'n en concurrentiële reactie}

In deze paragraaf zal een model worden gepresenteerd voor de beschrijving en analyse van PKV'n en concurrentiële reacties. Daarbij wordt getracht inzicht te verkrijgen in:

1) De aanleiding voor het aanbrengen van de betreffende PKV.

2) De soort PKV.

3) De reactie van de concurrentie.

4) Het financiële resultaat en het resultaat ten aanzien van het marktaandeel.

ad 1) De aanleiding voor het aanbrengen van PKV'n kan inzicht verschaffen in het continue concurrentieproces van acties en concurrentiële reacties. Als aanleidingen te vinden zijn bij concurrenten geeft dit inzicht in het belang van concurrentiële acties bij het initiëren van PKV'n.

ad 2) Dat de soort PKV van belang is wordt uitgebreid beargumenteerd door Garvin (1984b). Het is voor een onderneming van belang zorgvuldig de soort PKV te bepalen, enerzijds met het oog op de relatieve kwaliteitspositie, en anderzijds met het oog op mogelijke concurrentiële reacties.

ad 3) De reactie van de concurrentie kan van belang zijn voor het succes van de kwaliteitsverbetering in termen van financieel resultaat en marktaandeel, en stat centraal in dit onderzoek.

ad 4) De mate van succes van de kwaliteitsverbetering wordt afgemeten aan het financiële resultaat van de onderneming en de verandering in het marktaandeel als gevolg van de PKV. Deze indicatoren worden onder andere ook gebruikt in het PIMS-onderzoek.

De kwaliteitsverbetering die wordt bestudeerd is gedefinieerd als "de meest belangrijke produktkwaliteitsverbetering die de onderneming heeft doorgevoerd in de laatste vijf jaar". Er is bij de operationalisering gekozen voor cén kwaliteitsverbetering per onderneming. Uit het pilot-onderzoek is gebleken dat het voor respondenten moeilijk is in een schriftelijke vragenlijst voor verschillende PKV'n afzonderlijk aan te geven wat per 
PKV de unieke reacties zijn geweest van de concurrenten ${ }^{26}$. Bij het centraal stellen van cén PKV konden de respondenten wel een betrouwbaar beeld verstrekken, mits deze PKV betrekking heeft op het belangrijkste produkt of de belangrijkste produktcategorie van de onderneming en slechts gevraagd wordt naar de reactie van de belangrijkste concurrent. De resultaten van het pilot-onderzoek hebben ertoe geleid dat uiteindelijk voor deze onderzoeksopzet is gekozen.

Het verbeteren van de produktkwaliteit vindt plaats binnen de context van de markt waarin de onderneming opereert. Daarnaast bezit de onderneming zelf een aantal kenmerken (waar onder de gehanteerde marketing-strategie). In figuur 4.1. staan de 4 onderdelen van het concurrentie-proces rond PKY'n naast de genoemde omgevingsvariabelen (markt) en ondernemingsvariabelen (onderneming zelf en marketing-strategie) weergegeven.

Figuur 4.1.2

Uitgebreid model voor produktkwaliteitsverbeteringen.

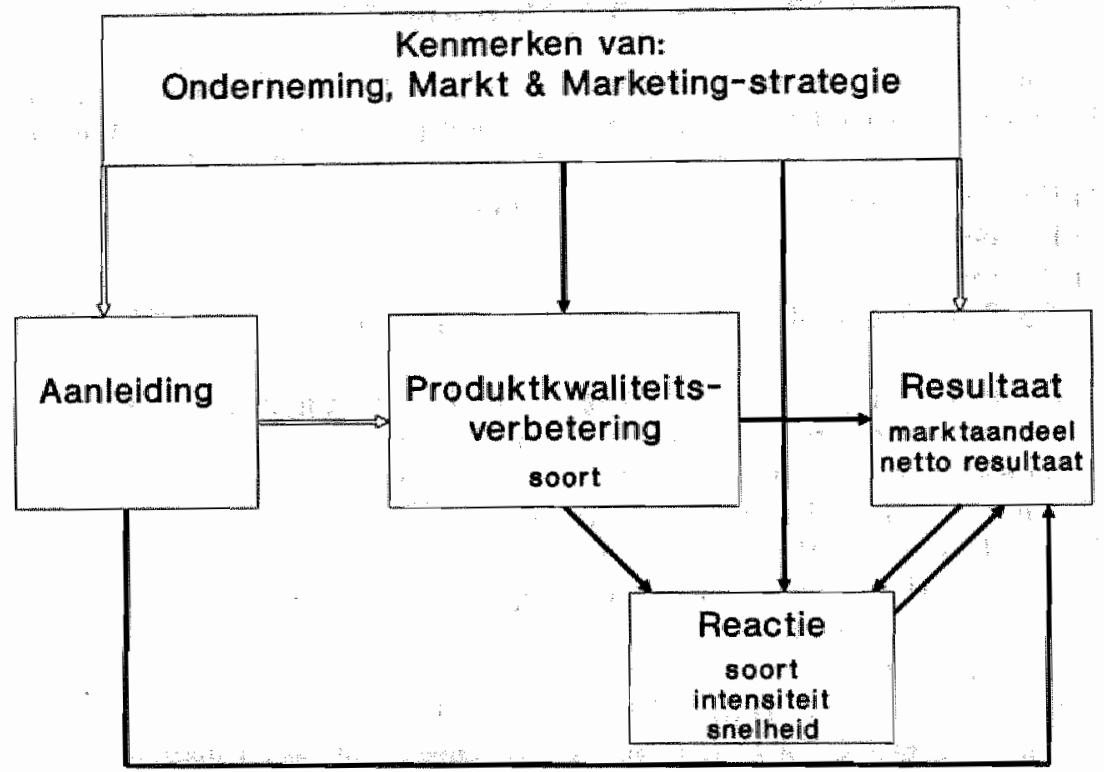

Alle onderdelen van het model worden nu toegelicht. Daarbij wordt onderscheid gemaakt tussen het exploratieve gedeelte van het model, waarover geen hypothesen (open pijlen) en het gedeelte waarover wel hypothesen zullen worden geformuleerd (gesloten pijlen).

Als basis voor het model hebben de percepties van de beslissers in de organisatie gediend. Derhalve is het concurrentieproces onderzocht vanuit de optiek van de beslisser, en worden de door de beslissers gepercipieerde concurrentięle reacties gehanteerd. Zolang 
men de reacties "goed waarneemt" gaat het ook om de feitelijke reacties. Hoewel, de beslisser kan deze natuurlijk altijd nog enigszins gefilterd en gekleurd waarnemen, dan wel er (al dan niet ongemerkt) een eigen interpretatie aan geven. Ook dan is het echter zo dat deze interpretatie de basis vormt voor allerlei beslissingen (Pfeffer \& Salancik 1978, Weick 1979). Het onderzoeken van management-percepties is een gebruikelijke werkwijze in concurrentie-onderzoek (Nightingale 1978, Lilien 1979, Moss 1981, Burke 1984 en in feite ook alle onderzoeken die zijn gebaseerd op de PIMS studies) en ook toepasbaar in ons onderzoek. Immers, toekomstige beslissingen zullen mede afhangen van de management-perceptie van het effect van PKV'n op de reactie van de concurrentie.

In de volgende sub-paragraaf (4.1.1.) wordt aandacht besteed aan de ongevingsvariabelen; namelijk de kenmerken van de onderneming, de marketing-strategie en de markt. Daarna komen de genoemde andere vier onderdelen uit het model aan de orde: de aanleidingen voor PKV'n (4.1.2.), de PKV'n zelf (4.1.3.), de reacties van de concurrent (4.1.4.) en het gepercipieerde resultaat van de PKV (4.1.5.).

\subsubsection{Kenmerken van de onderneming, de marketing-strategie en de markt}

Een onderneming verbetert de produktkwaliteit binnen een bepaalde marketing-strategie, die weer afhankelijk is van de concurrentie-omgeving van de onderneming. Daarnaast spelen andere kenmerken van de onderneming zelf en de markt een rol. Het model bevat dan ook deze drie elementen, die ook door onder andere Biggadike (1979) en Day \& Nedungadi (1989) worden aangegeven als determinanten van de perceptie van de concurrentiepositie door managers. Centraal in het model staat de beschrijving van concrete kwaliteitsverbeteringen die een reactie-termijn hebben van maximaal ongeveer 2 jaar. De beschrijving behandelt dus acties en directe reacties van ondernemingen binnen de marketing-strategie van de onderneming. De marketing-strategie die bedoeld is voor de langere termijn komt wel in het model voor als variabele die invloed heeft op de acties en reacties van de ondernemingen, maar wordt beschouwd als een constante over een bepaalde periode waarbinnen de PKV wordt doorgevoerd en de reactie plaatsvindt. Dat geldt eveneens voor de generieke strategie van de onderneming waarbinnen de marketingstrategie één van de functionele strategieën is.

\section{Ondernemingskenmerken.}

Als kenmerken van de onderneming zijn opgenomen de totale omzet en het netto resultaat (positief of negatief). Deze geven inzicht in de omvang en de financiële situatie van de onderneming, éen jaar voorafgaand aan het moment van rapporteren ${ }^{27}$. Deze indicatoren beschrijven de (potentiële) financiële middelen die ter beschikking staan voor het aanbrengen van PKV'n (vergelijk Day \& Nedungadi 1989). De variabelen in het model zijn derhalve:

1. Totale omzet in 1986.

2. Netto resultaat (positief/negatief) in 1986.

\section{Marktkenmerken.}

Als marktvariabelen zijn opgenomen: het aantal concurrenten, het marktaandeel, de fase in de produktlevenscyclus en een indicator voor het wel of niet gebruikelijk zijn van 
regelmatige $\mathrm{kw}$ aliteitsverbeteringen in de betreffende branche.

De marktsituatie gekenmerkt door het aantal concurrenten, het marktaandeel en de fase in de produkt-levenscyclus (groei van de markt) speelt een roll bij reacties van concurrenten op märkttoetredingen (zie Biggadike 1979). De reacties ten aanzien van kwaliteitsverbeteringen kunnen evenzeer afhankelijk zijn van de specifieke marktsituatie waarin de onderneming verkeert, deze kunnen derhalve ook gerelateerd zijn aan de genoemde factoren:

Het marktaandeel en het aantal concurrenten geeft een beeld van de concurrentiepositie. De fase in de produktlevenscyclus (Wasson 1978) is van belang bij de bepaling van de strategie ten aanzien van de inzet van marketing-mix instrumenten. In het algemeen heeft de fase in de produktlevenscyclus een belangrijke invloed op acties van ondernemingen (Dutton \& Jackson 1987).

De fasen die worden onderscheiden zijn, in navolging van de PIMS studies (Abell en Hammond 1980, Yip 1982, Day 1986, Buzzel \& Gale 1987):

1. Introduktiefase: De primaire vraag naar het produkt begint juist toe te nemen, de produkten of diensten zijn nog steeds onbekend voor veel potentiële gebruikers.

2. Groeifase: De vraag groeit met $10 \%$ of meer per jaar (reëel). De technologie en/of de concurrentiestructuur verandert nog steeds.

3. Verzadigingsfase: De produkten of diensten zijn bekend voor een grote meerderheid van potentiele gebruikers. De technologie en de concurrentiestructuur zijn redelijk stabiel.

4. Teruggangsfase: Produkten worden gezien als handelsartikel ("commodity"); minder sterke concurrenten treden uit de markt.

Als laatste variabele wordt het "gebruik" in de branche voor wat betreft de frequentie van PKV'n opgevoerd. Abbot (1955) geeft aan dat de frequentie van PKV' $n$ in de branche een indicator is voor de intensiteit van de kwaliteitsconcurrentie. In het algemeen worden acties van ondernemingen beïnvloed door de snelheid van veranderingen in technologie (Dutton \& Jackson 1987). In ons specifieke geval wordt het gebruik ten aanzien van de frequentie van PKV'n gezien als een benadering van de mate waarin produktveranderingen plaatsvinden. Dit kan de acties van ondernemingen beïnvloeden.

De variabelen in het model zijn derhalve:

1. Het aantal concurrenten.

2. Het marktaandeel.

3. Fase in de produktlevenscyclus (PLC).

4, Gebruik in de branche ten aanzien van kwaliteitsverbeteringen.

\section{Marketing-strategie.}

De marketing-strategie is het lange termijn kader waarbinnen de acties die op korte termijn worden ondernomen, geplaatst kunnen worden (vergelijk Day 1984). De marketing-strategie wordt beschreven door het door de onderneming toegeschreven belang aan zes actuele strategie-onderwerpen: prijs, service, produktkwaliteit, marktnis, "innovatiever zijn" en marktaandeel. Bij cen strategie waarbij bijvoorbeeld een concurrerende prijs belangrijk is, zijn er minder kwaliteitsverbeteringen te verwachten dan bij ondernemingen met een strategie gericht op produktkwaliteit. Wordt een strategie gevoerd waarbij de kwaliteit voorop staat dan is het aannemelijk dat de kwaliteit frequenter wordt verbeterd. 
De marketing-strategie en de fase in de PLC kunnen niet los van elkaar worden gezien. Dat verschillende marketing-strategieën geëigend zijin voor verschillende fasen in de PLC wordt door verschillende auteurs bevestigd (Wasson 1978, Leeflang 1987). Ondanks kritiek van Dhalla \& Yuspeh (1976) op onder andere de richting van het causale verband tussen marketing-strategie en fase in de PLC, komt Leeflang (1987) tot de conclusie dat het concept zeker als hulpmiddel voor de formulering van de marketing-strategie bruikbaar is.

De onderneming onderkent in haar marketing-strategie veelal een antal thema's. De onderneming is gevraagd welke thema's belangrijk zijn binnen de marketing-strategie, door een aantal punten toe te kennen aan het betreffende thema. Het minst belangrijke thema krijgt de minste punten, het meest belangrijke thema de meeste punten.

Respondenten geven het belang van deze onderwerpen aan door 100 punten te verdelen. De antwoorden geven inzicht in welke thema's belangrijker zijn dan andere in de marketing-strategie van de onderneming. Uiteraard is een combinatie van thema's mogelijk; het gaat om het belang van de verschillende thema's.

De thema-variabelen in het model zijn derhalve:

1. Concurrerende prijzen (PRIJS).

2. Goede service-verlening (SERVICE).

3. Kwalitatief goed produkt (KWALITEIT).

4. Afstemming op beperkte groep afnemers (MARKTNIS).

5. De concurrent een stapje voor zijn (INNOVATIEVER).

6. Marktaandeel vergroten (MARKTAANDEEL).

\subsubsection{Aanleidingen voor het aanbrengen van PKV'n}

Er kunnen diverse aanleidingen zijn om de kwaliteit van produkten te verbeteren. Naast de veelvuldig onderzochte "technology-push"-factoren en "demand-pull"-factoren is een aantal andere aanleidingen te onderscheiden. In het algemeen kunnen aanleidingen gevonden worden bij uitingen van klanten of gebruikers, bij concurrenten of bij derden, zoals de overheid, certificatie-instituten of consumenteninstanties. Ook kunnen interne bedrijfsfactoren een impuls vormen om PKV'n door te voeren. In ons model wordt uitgegaan van aanleidingen die in de perceptie van de beslissers relevant zijn. De aanleiding kan dus gevonden worden binnen de onderneming zelf, bij klanten of gebruikers, bij concurrenten of bij derden.

Binnen de onderneming zelf.

De aanleiding kan liggen binnen de onderneming. De technische mogelijkheden van ondernemingen worden groter, zodat produkteigenschappen kwalitatief verbeterd kunnen worden. Technologische vooruitgang kan het gevolg zijn van research en developmentactiviteiten van de onderneming zelf, maar ook van activiteiten van onafhankelijke onderzoek-instituten (bijvoorbeeld TNO, Energie Onderzoek Centrum Nederland, KEMA) en onderzoek van universiteiten. In de literatuur wordt deze aanleiding vaak omschreven als "technology push".

De beschikbaarheid van kapitaal binnen de onderneming kan zodanig "overvloedig" zijn dat additionele investeringen in verbeterde produktieprocessen of het gebruik van hoogwaardiger materialen mogelijk is (vergelijk "organizational slack" van Cyert \& March 1963).

Een laatste aanleiding kan zijn een wijziging in de organisatie, waardoor een positieve 
impuls gegenereerd wordt in de richting van het afleveren van betere produkten. Voorbeelden van deze laatste activiteiten zinn het inrichten van een organisatie afgestemd op het hanteren van de "integrale kwalliteitszorg" filosofie, die onder meer kan uitmonden in zogenaamde kwaliteitskringen. Uiteraard kunnen aanleidingen om kwaliteitszorgprojecten op te starten weer bij bijvoorbeeld klanten of gebruikers liggen of onderdeel zijn van een op kwaliteit gerichte marketing-strategie. De in het model gehanteerde variabelen zijn:

1. Technische mogelijkheden.

2. Beschikbaarheld van kapitaal.

3. Verandering in de organisatie.

\section{Klanten en gebruikers.}

Er kunnen ook aanleidingen gevonden worden bij klanten van de onderneming en gebruikers van de produkten. In een aantal gevallen zijn dit twee verschillende groepen; bijvoorbeeld hoeft de gebruiker niet de afnemer (klant) te zijn. De behoeften van gebruikers zijn aan veranderingen onderhevig. Zo spelen culturele, sociale, demografische en economische veranderingen een rol.

Door het uiten van ontevredenheid of het naar voren brengen van specifieke wensen maken zij kenbaar dat verbeteringen of aanpassingen aan het produkt wenselijk zijn. In de literatuur wordt deze aanleiding vaak omschreven als een "market pull"situatie.

De in het model gehanteerde variabelen zijn:

1. Wensen van afnemers.

2. Wensen van gebruikers.

3. Ontevredenheid van afnemers.

4. Ontevredenheid van gebruikers.

\section{Concurrenten.}

Acties van concurrenten kunnen er verantwoordelijk voor zijn dat de druk om de concurrentiepositie te handhaven groter wordt. Kwaliteit is een relatief begrip en dat betekent in dit geval dat wanneer de relatieve produktkwaliteit van een onderneming afneemt door verbetering van de kwaliteit bij de concurrentie, de concurrentiedruk toeneemt. De concurrentiepositie kan dus wijzigen door kwaliteitsverbeteringen die de concurrentie aanbrengt, maar ook door andersoortige acties van concurrenten, zoals prijsverlagingen, verhogingen van promotionele budgetten, assortimentsuitbreidingen e.d.. De in het model gehanteerde variabelen zijn:

1. Kwaliteitswerbetering van concurrenten.

2. Andere actie van concurrerende ondernemingen.

\section{Derden,}

Wijzigingen van bepalingen, regels en wetten kunnen de aanleiding vormen om de kwaliteit te verbeteren. De owerheid speelt hierin een rol, met bijvoorbeeld strengere eisen ten aanzien van produktaansprakelijkheid, veiligheid en wettelijke maatregelen in bijvoorbeeld de Warenwet en de Hinderwet. Kwaliteitsverbeteringen die uit wetten of richtlijnen voortkomen worden vaak niet in eerste instantie door de consument waargenomen. Het houdt echter wel in dat het produkt daardoor impliciet kwalitatief beter wordt. Het wordt min of meer opgelegd door de overheid aan een ieder in de bedrijfstak. Ook kan het voorkomen in het kader van kwaliteitstimuleringsprogramma's van de overheid (zie hoofdstuk 1). 
Ten aanzien van kwaliteitsverbeteringen spelen in enkele branches verordeningen van Produktschappen en certificatie-eisen een grote rol. Kwaliteitsverbeteringen worden dan aangebracht om het bedrijf en daarmee ook het produkt te certificeren. Een dergelijk certificaat is van belang bij de kwaliteitspositie die dat bedrij inneemt in de ogen van de klant ten opzichte van de concurrentie.

Vertegenwoordigende organen van klanten, zoals de Consumentenbond, gaan uit van het belang van de consument en kunnen door samenbundeling van krachten invloed uitoefenen op produktontwikkeling en kwaliteit van produkten. $\mathrm{Zij}$ kunnen ook de overheid of branche-organisaties attenderen op de noodzaak van regulering; deze kunnen vervolgens besluiten hier al dan niet aan tegemoet te komen.

De in het model gehanteerde variabelen zijn:

1. Regelingen van overheidsinstanties.

2. Aanpassing aan certificatie-eisen.

3. Regelingen van consumenteninstanties.

\subsubsection{Produktkwaliteitsverbeteringen}

De PKV' $n$ in het onderzoek zijn te omschrijven als de meest belangrijke verbetering die de onderneming in de laatste vijf jaar heeft aangebracht in de kwaliteit van het produkt. Dit is in de vragenlijst bij het onderzoek niet nader omschreven omdat de perceptie van de kwaliteitsverbetering van belang is. Door de kwaliteitsverbetering nader te omschrijven zouden respondenten gedwongen worden zich te conformeren aan een vooraf bepaalde definitie die slechts voor enkele branches een voldoende en uitputtende antwoordmogelijkheid zou bieden. De antwoorden worden verkregen door middel van een open vraag, waarin de respondent een omschrijving geeft van de kwaliteitsverbetering. Deze vraag werd dus niet voorgecodeerd. De verbeteringen hebben bijvoorbeeld betrekking op, zoals uit het empirisch onderzoek zal blijken:

-Verandering in de constructie.

-Gebruik van andere materialen of componenten.

-Verbeteringen in mogelijkheden tot gebruik in bepaalde toepassingen.

-Verbetering van de verpakking.

Zoals in hoofdstuk 3 reeds is aangegeven, kunnen vervolgens verschillende soorten PKV'n worden onderscheiden. In ons onderzoek wordt gebruik gemaakt van de indeling van Garvin (1984b):

1. "performance" (PER): de primaire kenmerken van het produkt.

2. "features" (FEA): de "toeters en bellen" van het produkt.

3. "reliability" (REL): de betrouwbaarheid.

4. "conformance" (CON): de overeenstemming met de specificaties.

5. "durability" (DUR): de duurzaamheid.

6. "serviceability" (SER): de service-vriendelijkheid.

7. "aesthetics" (AES): de afwerking en "schoonheid".

8. "perceived quality" (PEQ): de reputatie en ongrijpbare produktkenmerken.

Volgens Garvin (1984b) komen in deze achtdeling drie vrij gebruikelijke zienswijzen (uit paragraaf 2.2.1.) op het begrip kwaliteit naar voren. Tot de produktgerichte benadering behoren de categorieën 1,2 en 5 ; tot de produktiegerichte benadering behoren de categorieën 3 en 4 , en tot de gebruikersgerichte benadering de categorieën 7 en 8 . Wilson 
(1986) voegt daaraan toe dat "serviceability" (categorie 6) tot de gebruikersgerichte benadering behoort. In ons onderzoek wordt daar waar mogelijk en zinvol één van de twee indelingen gehanteerd. De onderstaande tabel geeft de twee indelingen weer.

Tabel 4,1,: De indeling in verselhillende soorten PKV'n.

\begin{tabular}{llll} 
Benadering & A. Prodult & B. Produktic & C. Gebruikers \\
\hline & & & \\
Categorie: & 1. Performance & 3. Reliability & 6. Serviceability \\
& 2. Features & 4. Conformance & 7. Aesthetics \\
& 5. Durability & 8. Perceived Quality \\
\hline
\end{tabular}

\subsubsection{Reacties van de meest belangrijke concurrent}

In deze paragraaf wordt een drietal aspecten van de concurrentiële reacties besproken. Achtereenvolgens wordt aandacht besteed aan:

1. De soort reactie van de concurrent.

2. De intensiteit van de reactie door de concurrent.

3. De tijd tot de concurrent reageert.

ad.1. Soort reactie van de concurrent.

Zoals eerder is aangegeven maken Kinnear en Bernhardt (1986) onderscheid tussen een aantal aspecten van het totale produkt. Een vergelijkbare indeling is gehanteerd bij de specificering van de reactiemogelijkheden van concurrenten. $\mathrm{Zo}$ is er:

a) Een zevental reactiemogelijkheden die onder het instrument "produkt" zijn te vatten.

b) De introductie van een nieuw produkt, of toevoeging aan een bestaand assortiment.

c) Een zevental instrumenten die behoren tot de marketing-mix instrumenten prijs, promotie en distributie.

De zeven reactiemogelijkheden bij a) zijn onderverdeeld in drie PKV' $n$ in enge zin en vier verbeteringen van de service rond het produkt (produkt "plus").

De variabelen waarmee de concurrentiële reactie is gemeten, zijn:

Produkt:

1. Kwaliteit: "Kwaliteitsverbetering"

2. Prestatie: "Verbetering van de prestaties van het produkt"

3. Vormgeving: "Verbetering van de vormgeving"

Produkt "plus":

4. After-sales service: "Verbetering van de after-sales service"

5. Verkoopswoorwaarden: "Verbetering verkoopsvoorwaarden"

6. Garantie: "Verbetering garantie-voorwaarden"

7. Afleverings-service: "Verbetering van de service bij aflevering" 
Nieuw produkt:

8. Nieuw produkt: "Ontwikkelen van een nieuw produkt"

9. Assortiment: "Uitbreiden van het assortiment"

Prijs.

10. Prijsverlaging

11. Prijsverhoging

Promotie:

12. Tijdelijke acties: "(Tijdelijke) verkoopacties"

13. Imago: "Aanpassing imago (door bijv. reclame)"

14. Promotie/reclame: "Verhoogde promotie/reclame"

15. Merknaam: "Verandering merknaam"

Distributie:

16. Distributie: "Keuze voor andere distributiekanalen".

Figuur 4.2.: Reactiemogelijkheden van de concurrent naar andeiding van een $\mathrm{PKV}$.

ACTIE:

Onderneming $X$ verbetert produktkwaliteit

\begin{tabular}{|c|c|}
\hline $\begin{array}{l}\text { Concurrent } Y \\
\text { reageert }\end{array}$ & $\begin{array}{l}\text { Concurrent } Y \\
\text { reageert niet }\end{array}$ \\
\hline \multicolumn{2}{|c|}{ Reactie-mogelljkheden } \\
\hline $\begin{array}{l}\text { Produkt } \\
\text { kwallteit } \\
\text { prestatio } \\
\text { vormgeving }\end{array}$ & $\begin{array}{l}\text { Prijs } \\
\text { prijswerlaging } \\
\text { prijsverhoging }\end{array}$ \\
\hline $\begin{array}{l}\text { Produkt "plus" } \\
\text { after-sales service } \\
\text { verkoopsvoorwaarden } \\
\text { garantie } \\
\text { afleverings-service }\end{array}$ & $\begin{array}{l}\text { Promotie } \\
\text { tijdelijke acties } \\
\text { imago } \\
\text { promotie/reclame } \\
\text { merknaam }\end{array}$ \\
\hline $\begin{array}{l}\text { Nieuw produkt } \\
\text { nleuw produkt } \\
\text { assortiment }\end{array}$ & $\begin{array}{l}\text { Distributie } \\
\text { distributie }\end{array}$ \\
\hline
\end{tabular}


Het is uiteraard ook denkbaar dat concurrenten niet reageren. Verder is het mogelijk met cen instrument te reageren (enkelvoudige reactie) of met meer instrumenten tegelijk te reageren (meervoudige reactie).

De reactiemogelijkheden zijn onder andere gebaseerd op de reeds genoemde produktindeling van Kinnear \& Bernhardt (1986), aangevuld met de overige elementen van de marketing-mix: prijs, promotie en distributie. Er is voor gekozen het imago en de merknaam niet onder te brengen bij het instrument produkt, maar bij het instrument promotie. Het communicatieve aspect bij imago en merknaamveranderingen speelt een zodanig belangrijke rol dat hiervoor gekozen is. Overigens worden bijvoorbeeld eventuele fysieke aanpassingen an het produkt gepaard gaande met imago en merknaamveranderingen eveneens ondergebracht bij het instrument produkt. In figuur 4.2. zijn de reactiemogelijkheden schematisch weergegeven (Lemmink 1987, Lemmink \& Kasper 1990).

Het is echter mogelijk dat concurrenten hun marketing-mix veranderen, zonder dat sprake is van een reactie op kwaliteitsverbeteringen.

Om deze reacties buiten te sluiten, zal de nadruk moeten liggen op het onderzoeken van die reacties die in de opinie van de managers een direct gevolg waren van een kwaliteitsverbetering. Tevens gaat het om de reactie van de belangrijkste concurrent, om de antwoorden zo valide mogelijk te laten zijn. Immers, men mag er in het algemeen vanuit gaan dat managers de meeste informatie beschikbaar hebben over hun belangrijkste concurrenten, waar men ook de "meeste last" van zal hebben.

\section{ad.2. Intensiteit van de reactie; reactie-intensiteit (RD).}

De intensiteit van de reactie kan worden gemeten met behulp van het aantal instrumenten waarmee men reageert. Theoretisch is het mogelijk dat de intensiteit in ons onderzoek de waarde 0 (in geval van geen reactie) tot en met 16 (in geval van reactie met elk van de 16 genoemde instrumenten) aanneemt. Robinson (1988; p. 372) geeft aan dat informatie over de reactiesterkte van elk afzonderlijk instrument bij een dergelijke aggregatiewijze verloren gaat. Aan de andere kant levert het wel een globale maatstaf op die vrij eenvoudig te hanteren is en bovendien relevant blijkt te zijn in het economisch onderzoek naar concurrentiêle reacties.

ad.3. Tijd tot de reactie van de belangrijkste concurrent; reactie-snelheìd (RS). Tevens is van belang hoelang het geduurd heeft voordat de belangrijkste concurrent op eên of andere wijze heeft gereageerd. Dit gegeven dient tevens als controlemiddel op de termijn waarbinnen nog een reactie redelijkerwijs te achterhalen is zonder dat van interferentie met andere aanleidingen sprake is. Bovendien geeft het een indicatie van de urgentie die door de concurrentie gevoeld wordt om te reageren en de snelheid waarmee men in staat is te reageren.

\subsubsection{Het gepercipieerde resultaat van de kwaliteitsverbetering}

Om cen indicatie te geven van het effect van een PKV, kan het zinvol zijn om het gepercipieerde resultaat in termen van toename of afname van de netto winst of het marktaandeel te meten. Het is, objectief gezien, uiteraard moeilijk om de directe bijdrage van kwaliteitsverbeteringen hieraan exact te koppelen. Mede om die reden wordt gebruik gemaakt van gepercipieerde resultaten.

Verschillende auteurs hebben getracht een causaal verband te leggen tussen relatieve 
produktkwaliteit en "performance"-indicatoren, zoals winst en marktaandeel, op basis van de PIMS-studies. De resultaten duiden erop dat relatieve produktkwaliteit een positieve invloed heeft op het marktaandeel (Phillips, Chang \& Buzzel 1983, Jacobson \& Aaker 1987) en op de winstgevendheid (Schoeffler, Buzzel \& Heany 1974, Jacobson \& Aaker 1987). Het verschil van onze aanpak met die van deze auteurs ligt in het feit dat deze onderzoeken die op PIMS gebaseerd zijn, geanalyseerd zijn met behulp van cross-sectie analyses en longitudinale econometrische analyses. Het causale verband wordt door een dergelijke onderzoeksopzet uit de gegevens afgeleild met behulp van statistische technieken. In onze opzet wordt expliciet gevraagd naar het causale verband tussen verbetering van produktkwaliteit en resultaat. Dit is enerzijds een beperking van een eenmalig onderzoek, maar anderzijds een voordeel omdat nu dieper kan worden ingegaan op overwegingen (aanleidingen), reactiepatronen en de betekenis hiervan voor het resultaat van de PKV.

De resultaten van produktkwaliteitsverbeteringen worden in de literatuur veelvuldig gerelateerd aan het ontwikkelingsproces van nieuwe produkten, inclusief de aanleidingen. Zo concludeert Arnold (1985) in een studie naar technologische veranderingen op basis van het "Schumpeteriaans paradigma" dat consumenten worden "opgevoed" door producenten. Producenten kunnen consumenten produkten opdringen. Echter de vraagzijde van de markt is op deze wijze niet volledig te beïnvloeden. Succesvolle recepten voor nieuwe produkten gaan uit van zowel de behoeften van de klant als de wensen van de producent. In de onderzoekstraditie naar het nieuw produktontwikkelingsproces komt naar voren dat succesvolle nieuwe produkten (zeker gedeeltelijk) gebaseerd zijn op behoeften of directe verzoeken of vragen van klanten (Peplow 1960, Von Hippel 1978). Vaak blijkt dan dat de behoeften van klanten bekend zijn, maar de technische ontwikkeling om aan die behoefte te voldoen nog moet plaatsvinden. Uit eerder onderzoek van Von Hippel (1976) in de markt van technisch-wetenschappelijke instrumenten blijkt dat voor de succesvolle "minor improvements" nog altijd in $70 \%$ van de gevallen de gebruiker de bron van de innovatie is. Bij "major improvements" en "echte" innovaties bedraagt dit percentage respectievelijk 82 en 100. Wanneer PKV' $n$ en "minor improvements" vergelijkbaar geacht worden dan is het belang van de inbreng van de gebruiker minder dan bij innovaties, maar nog steeds aanzienlijk. Succesvolle PKV'n zullen waarschijnlijk zowell op klantenwensen als technische mogelijkheden van de organisatie zelf gebaseerd moeten zijn.

Tot slot hangt het succes van een PKV af van de reactie-snelheid en -intensiteit van de concurrent. Cardozo (1981) concludeert dat ten aanzien van alle mogelijke marketing-mix reacties van de concurrent geldt dat de mate waarin de PKV succes heeft, afhankelijk is van onder andere de waarschijnlijkheid en snelheid waarmee concurrenten op deze verbeteringen zullen reageren.

Het succes kan worden uitgedrukt in marktaandeelwinsten en financiële resultaten. Als variabelen in het model zijn derhalve opgenomen:

1. Marktaandeel.

2. Netto resultaat.

\subsection{Hypothesen voor het empirisch onderzoek}

In deze paragraaf wordt een aantal hypothesen geformuleerd, gegroepeerd rond de onderdelen van het model. Eerst wordt een drietal hypothesen geformuleerd ten aanzien 
van de relatie tussen de produktlevenscyclus en PKV'n (A). Vervolgens staan de reacties van de concurrent (B) centraal. Tot slot wordt een aantal hypothesen geformuleerd over het gepercipieerde resultaat voor de ondememing als gevolg van de PKV (C). Telkens zal bij de hypothesen verwezen worden naar de overwegingen uit de theorie en empirische bevindingen van het literatuuronderzoek. Deze zijn hoofdzakelijk te vinden in hoofdstuk 3 en in de hieraan voorafgaande paragrafen van hoofdstuk 4. Eerst zal de plaats van de hypothesen worden aangeven in het model (zie figuur 4.3.). De letter-cijfer combinaties corresponderen met de hypothesen, die na het model worden geformuleerd. De hypothesen A1 en B4 over respectievelijk het aantal PKV' $n$ in de verschillende fasen van de produktlevenscyclus en het verschil in reactie-intensiteit tussen de industriele en de consumentenmarkt komen niet expliciet in het model voor. Zij zullen apart worden besproken. Met nadruk dient hier vermeld te worden dat zowel in de formulering van de hypothesen als in het empirisch onderzoek met "concurrentiële reactie" of "reactie van de concurrent" wordt bedoeld "de reactie van de meest belangrijke concurrent".

Figuur 4.3.: Beperkt model woor produktkwaliteitsverbeteringen, met slechts die relaties waarover hypothesen worden geformuleerd.

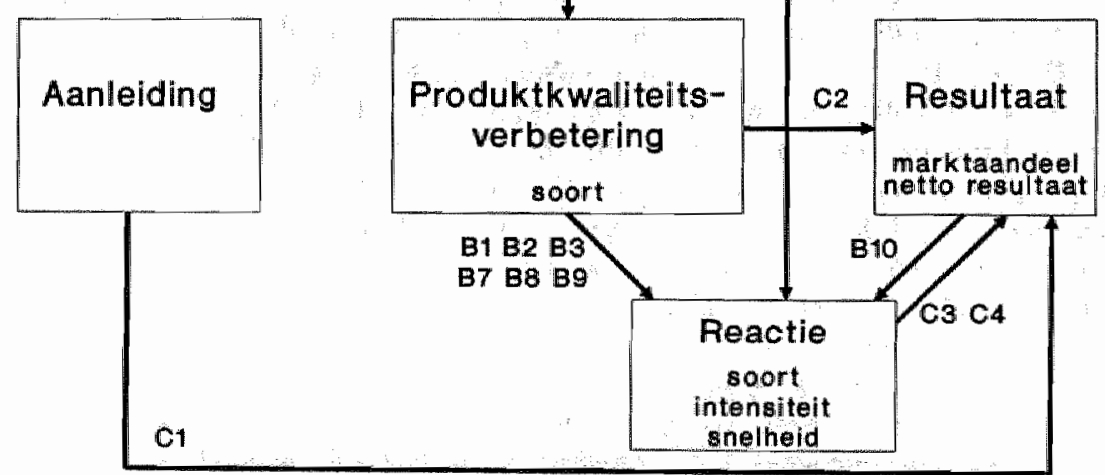




\section{A. De relatie tussen produktlevenscyclus (PLC) en PKV'n:}

Hypothese A1: Het aantal PKV'n is hoger in de introductie- en groeifase van de produktlevenscyclus dan in de verzadigings- en teruggangsfase.

Wasson (1978) suggereerde dat in latere fasen van de PLC het produkt meer gestandaardiseerd is en dat er weinig technologische mogelijkheden zijn om PKV'n door te voeren. De nadruk van PKV'n ligt in de eerste fasen van de PLC (zie ook Mickwitz 1959, De Jong 1972). Ten aanzien van markttoetredingen vinden Hause \& Du Rietz (1984) en Robinson (1988) meer markttoetredingen in groeimarkten. Analoog hieraan en op basis van de voorgaande beschouwingen wordt in de bovenstaande hypothese gesteld dat het aantal PKV'n hoger is in de introductie- en groeifase van de produktlevenscyclus dan in de verzadigings- en teruggangsfase.

Een voorbehoud is echter dat Wasson (1978) voorziet dat in de verzadigingsfase van de PLC "perceived product improvements" plaatsvinden, voornamelijk doelend op ongrijpbare PKV' $n$, zoals reputatie en imago, maar ook "toeters en bellen" en bijwoorbeeld verpakking. Dit worden ook wel quasi-kwaliteitsverbeteringen genoemd.

Hypothese A2: In de introductie- en groeifase worden relatief veel "grijpbare" PKV'n gerealiseerd, terwijl in de verzadigingsfase relatief veel "ongrijpbare" PKV'n gerealiseerd worden.

De fase van de produktlevenscyclus waarin het produkt zich bevindt, is medebepalend voor de soort PKV. Met andere woorden, in verschillende fasen van de produktlevenscyclus worden verschillende soorten PKV'n doorgevoerd. Refererend aan het genoemde onder de vorige hypothese is de verwachting dat de ongrijpbare PKV'n en PKV'n die niet de essentie van het produkt betreffen in de verzadigingsfase de overhand hebben om produktdifferentiatie te creerren bij technisch uitgekristalliseerde produkten (Wasson 1978).

Hypothese A3: In het begin van de produktlevenscyclus komen vooral PKV'n voor met als uitgangspunt het produkt, en aan het eind van de produktlevenscyclus komen vooral PKV"n voor met als uitgangspunt de produktie.

Deze hypothese is gebaseerd op de conclusies van Utterback \& Abernathy (1975) en Moore \& Tushman (1980), waarin zij tot de conclusie komen dat produktinnovatie in het begin, en procesinnovatie aan het eind van de produktlevenscyclus relatief belangrijker is. 
B. Reacties wan de concurrent:

Inventarisatie van concurrentiele reacties:

Hypothese B1: De typische reactie van de concurrent op een PKV is geen reactie. Het aantal PKV'n zonder een reactie van de concurrent is groter dan het aantal PKV'n met een reactie van de concurrent.

Deze hypothese is gebaseerd op uitspraken van Biggadike (1979) en Robinson (1988).

Hypothese B2: De reactie van de concurrent op een PKV is in de meeste gevallen eveneens een PKV.

Booy (1965) komt na bestudering van een aantal bedrijfstak-studies tot de conclusie dat opvallend veel navolging plaatsvindt, met name bij kwaliteitsveranderingen van produkten en service. Er zijn ook andere bevindingen in de literatuur. Dat er niet alleen navolging plaatsvindt, maar dat ook reacties met andere marketing-mix instrumenten plaatsvinden, komt naar voren in een studie van Wildt (1974). Hij laat onder meer zien dat er door concurrenten op PKV"n ook wordt gereageerd met reclameuitgaven.

Hypothese B3: Voor zover er gereageerd wordt op een PKV door de concurrenten, bestaat deze reactie eerder uit een enkelvoudige reactie dan uit een meervoudige reactie.

Deze hypothese is vooral gebaseerd op resultaten van Robinson (1988). Er zijn ook andere bevindingen in de literatuur. Zo formuleren Lambin, Naert \& Bultez (1975) een model waarin plaats is voor reacties met meer dan eén instrument. Uit hun empirisch onderzoek blijkt dat deze meervoudige reacties in de praktijk ook zeker voorkomen. Hypothese B4: De reactie-intensiteit verschilt niet tussen een industriële markt en een
consumentenmarkt.

Deze hypothese is een conclusie ten aanzien van markttoetredingen uit het onderzoek van Robinson (1988), waarin geen verschil in intensiteit 
Produktlevenscyclus en concurrentiële reacties:

Hypothese B5: In de introductie- en groeifase worden relatief veel "grijpbare" reacties op een PKV gerealiseerd, terwijl in de verzadigingsfase relatief veel "ongrijpbare" reacties op een PKV gerealiseerd worden.

De fase van de produktlewenscyclus waarin het produkt zich bevindt, is van invloed op de soort concurrentiele reactie. Door combinatie van hypothese A2 over de grijpbare en ongrijpbare PKV'n in verschillende fasen van de produktlevenscyclus met de veronderstelde navolgingsstrategieën (hypothese B3) resulteert logischerwijs deze hypothese.

Hypothese B6: De intensiteit van de concurrentiele reactie in de verzadigingsfase van de produktlevenscyclus is groter dan in de groeifase.

Dit is wederom een hypothese analoog aan de hypothese van Biggadike (1979), die refereert aan een discussie tussen Marris (1968) en Alemson (1969) met betrekking tot de reactie-intensiteit op markttoetredingen.

Soort PKV en concurrentiële reacties:

Hypothese B7: De aard van de reactie van de concurrent verschilt al naar gelang de soort PKV.

In het algemeen gaan wij er vanuit dat er navolging plaatsvindt bij een PKV. Dit hoeft echter meer specifiek niet noodzakelijkerwijs te betekenen dat de reactie uit exact dezelfde elementen bestaat als de PKV. Deze hypothese is een exploratieve hypothese. Zoals Robinson (1988) reeds opmerkt, zijn er geen studies bekend die ingaan op de verklaring van de aard van de reactie bij toetredingen. Ook ten aanzien van PKV'n is geen empirisch onderzoek bekend.

Hypothese B8: De intensiteit van de reactie van de concurrent verschilt al naar gelang de soort PKV.

Garvin (1984b) onderscheidt acht soorten PKV'n (zie ook paragraaf 4.1.3.). Men kan zich afvragen of de reactie op elk van deze acht PKV'n even intensief zal zijn. Wij gaan er vanuit dat dit niet noodzakelijkerwijs het geval hoeft te zijn; echter het is niet zonder meer duidelijk bij welke soort de reactie het meest intensief zal zijn. 
Hypothese B9: De soort PKV is van invloed op de snelheid waarmee de concurrent reageert.

Men kan zich afvragen of de snelheid waarmee cen concurrent reageert op eén van de acht soorten PKV'n yoor elke soort even groot zal zijn. Wij gaan er vanuit dat dit niet noodzakelijkerwijs het geval hoeft te zijn; echter het is niet zonder meer duidelijk bij welke soort de reactie het snelst zal zijn.

Marktaandeelwinst als gevolg van PKV'n en intensiteit van concurrentiële reacties:

Hypothese B10: Hoe groter de marktaandeelwinst als gevolg van de PKV, hoe intensiever de reactie van de concurrent.

Verondersteld wordt dat een PKV die tot een grote stijging van het marktaandeel van de initiator leidt als zeer bedreigend ervaren wordt door de concurrent(en). Daardoor zullen zij zeer intensief reageren om hun verloren gegane positie terug te winnen. Hierbij dient men zich echter ook te realiseren dat de reactie op zich weer van invloed kan zijn op het behaalde resultaat (zie ook hypothese C4). Hopelijk kan op deze manier toch een eerste inzicht in deze samenhang verkregen worden.

\section{Het gepercipieerde resultaat van PKV'n:}

Hypothese C1: PKV'n gebaseerd op motieven die uitgaan van zowel klantenwensen als technische mogelijkheden zijn succesvoller ten aanzien van resultaat en marktaandeelgroei dan PKV'n die niet gebaseerd zijn op zowel klantenwensen als technische mogelijkheden.

Deze hypothese is gebaseerd op hetgeen naar voren is gebracht in paragraaf 4.1.5..

Hypothese C2: De soort PKV is van invloed op het resultaat (netto resultaat en marktaandeel) van de PKV.

Deze hypothese is exploratief van aard, en tracht antwoord te vinden op de vraag of bepaalde soorten PKV'n succesvoller zijn dan andere soorten PKV'n. Het is niet a priori vast te stellen welke soort PKV tot het hoogste netto resultaat of marktaandeel zal leiden. 
Hypothese C3: De snelheid waarmee de concurrentie reageert, heeft een negatief effect op het gepercipieerde resultaat (netto resultaat, marktaandeel).

De mate waarin PKV succes heeft, is afhankelijk van onder andere de snelheid waarmee concurrenten op deze verbetering zullen reageren (zie paragraaf 4.1.5).

Hypothese C4: Naarmate de intensiteit van de concurrentiele reactie toeneemt, is het negatieve effect op het gepercipieerde resultaat (netto resultaat, marktaandeel) groter.

Deze hypothese sluit aan bij hetgeen in hoofdstuk 3 en paragrafaf 4.1.5. gezegd is over de intensiteit van concurrentiële reacties en de effecten daarvan op de resultaten die de initiator van een PKV met deze PKV behaalt.

In hoofdstuk 5 wordt hypothese A1 besproken. In hoofdstuk 6 wordt hypothese B4 behandeld omdat daarvoor een vergelijking tussen de industriële markt en de consumentenmarkt nodig is. De overige hypothesen komen in hoofdstuk 7 aan de orde. 
मैं $\mathrm{B}, \cdots$

6. $\quad 8$

$\because \quad 98+8$

$\mathrm{H}^{\circ}$ औकी :

H. Pि :

जिता से

:

क : $: 48+$ 


\section{Opzet van het empirisch onderzoek en profiel van de populatie}

Het model dat in het vorige hoofdstuk is ontwikkeld en de bijbehorende hypothesen zullen worden getoetst aan de hand van een cross-sectioneel onderzoek bij een aantal Nederlandse ondernemingen. Dan kan worden nagegaan of en zo ja, in hoeverre het model en de hypothesen bevestigd worden in de realiteit. Voor zover ons bekend, is ons onderzoek het eerste onderzoek op dit terrein. Vandaar dat de resultaten van het onderzoek gedeeltelijk een tentatief karakter hebben. Door vergelijkingen met enigszins vergelijkbaar onderzoek, zal getracht worden de resultaten te veralgemeniseren.

In dit hoofdstuk wordt eerst de opzet van de steekproef en het profiel van de respons besproken (paragraaf 5.1. en 5.2.). Vervolgens wordt de selectie van twee produkt/markt combinaties voor nader onderzoek behandeld (paragraaf 5.3.). Daarna worden (in paragraaf 5.4.) de twee produkt/markt combinaties op een aantal kenmerken (externe omgeving, marketing-strategie en ondernemingskenmerken) vergeleken. Tot slot volgen de conclusies in paragraaf 5.5 ..

\subsection{Opzet van de steekproe $\mathrm{f}^{28}$}

$\mathrm{Na}$ pilot-interviews met leidinggevenden in 14 ondernemingen werd in november 1987 een vragenlijst verstuurd naar 1959 ondernemingen in Nederland. De populatie bestond uit:

a) Een steekproef uit een deel van de industriële bedrijven in Nederland met meer dan 10 werkzame personen, geregistreerd bij de Kamers van Koophandel, aangevuld met informatie van enige branche-organisaties.

b) Vrijwel alle ondernemingen, aangesloten bij een Regionale Kwaliteitskring in Nederland.

In totaal hebben 666 ondernemingen gereageerd $(=34 \%)$ op de vragenlijst. Van deze ondernemingen hebben 384 ondernemingen gedetailleerde informatie gegeven. De overige ondernemingen reageerden overwegend door een verkorte vragenlijst in te vullen, voornamelijk bedoeld om inzicht te verkrijgen in de non-respons. In het algemeen zullen de ondernemingen (vanwege de genoemde selectieve populatie) meer dan gemiddeld aandacht hebben voor kwaliteitsvraagstukken. Enerzijds vanwege het lidmaatschap van een Regionale Kwaliteitskring en anderzijds door het invullen en terugsturen van de vragenlijst. Bij het rapporteren van de resultaten dient men zich derhallve te realiseren dat de steekproef geen afspiegeling is van alle industriële bedrijven in Nederland. Echter, met betrekking tot het doel van deze studie, het analyseren van concurrentiele reacties ten aanzien van PKV'n, is dit geen bezwaar. In ons onderzoek staan concurrentiële reacties, gegeven een aantal PKV'n, centraal.

Voor een uitgebreide verantwoording van het pilot-onderzoek, de steekproefopzet en de vragenlijst zie bijllagen $C$ en $D$. 


\subsection{Profiel van de totale populatie}

In deze paragraaf zal een profiel worden gegeven van de totale populatie aan de hand van een aantal variabelen uit het model. Vervolgens worden twee variabelen, namelijk de fase in de produktlevenscyclus en de marketing-strategie, aan elkaar gerelateerd. De afstemming van de marketing-strategie op de fase in de levenscyclus van een produkt is een veeibesproken onderwerp. Vandaar, dat in het kader van deze studie, deze relatie onderzocht zal worden om enig inzicht te geven in de populatie van ondernemingen in ons onderzoek. Tot slot wordt geinventariseerd hoe vaak ondememingen PKV'n doorgevoerd hebben in de periode 1983-1987, en in welke fasen van de PLC de meeste PKV'n plaatsvinden.

De totale respons bedroeg 384 ondernemingen, met een gemiddeld marktaandeel in de door henzelf afgebakende markt van ruim $21 \%$. Het gemiddeld aantal concurrenten bedroeg 47 , waarbij bijna $68 \%$ van de ondernemingen 10 of minder concurrenten percipieert. Het belangrijkste produkt van de meeste bedrijven $(59 \%)$ bevindt zich in de verzadigingsfase van de produktlevenscyclus. In de marketing-strategie liggen de belangrijkste accenten op kwaliteit (gewicht van 33 punten van de 100), service (21) en prijs (18). $61 \%$ van de bedrijven rapporteert dat het in hun branche gebruikelijk is dat de produktkwaliteit regelmatig wordt aangepast. Verder is de omzet en het netto resultaat van de ondernemingen in 1986 bekend. $16 \%$ heeft een omzet (excl. BTW) van meer dan 100 miljoen gulden; $38 \%$ een omzet van minder dan 10 miljoen gulden. Het netto bedrijfsresultaat is voor $13 \%$ van de ondernemingen negatief.

Ten aanzien van de relatie tussen marketing-strategie en fase in de produktlevenscyclus kunnen de volgende conclusies worden getrokken (zie tabel 5.1.). Kwaliteit krijgt het hoogste gewicht in elke fase van de produktlevenscyclus. Ten aanzien van kwaliteit is er geen statistisch significant verschil in gewicht tussen de fasen van de produktlevenscyclus. Verder blijkt dat service met name in de eerste fasen een hoog gewicht krijgt. Het gewicht van "innovatiever zijn" is het hoogst in de groeifase en het laagst in de teruggangsfase. Bij het gewicht van de prijs blijkt dat vooral prijsconcurrentie plaatsvindt in de latere fasen van de produktlevenscyclus. Tabel 5.1. geeft de gewichten (in punten) aan die zijn toegekend aan de verschillende accenten, die in de marketing-strategie kunnen worden onderscheiden.

In bijna $11 \%$ van de gevallen wordt door de onderneming aangegeven dat er géén PKV heeft plaatsgevonden in de periode 1983-1987. Bijna $27 \%$ van de ondernemingen geeft aan dat de produktkwaliteit meer dan 20 keer is verbeterd in die periode of continu wordt verbeterd.

De fase in de produktlevenscyclus heeft waarschijnlijk invloed op het aantal PKV'n, Vanwege het feit dat een produkt in de introductiefase of de groeifase nog niet de ideale samenstelling heeft gekregen, zijn er nog voldoende mogelijkheden om PKV'n aan te brengen. Dit in tegenstelling tot de verzadigings- en teruggangsfase. ondernemingen de rechte tellingen van de vragen die de variabelen uit het model betreffen zijn opgenomen. 
Tabel 5.1:" Accenten binnen de marketing-strategie in de verschillende fasen van de produkt levenscyclus (total over alle produkt marktcombinaties; $\mathrm{n}-321^{30}$ ).

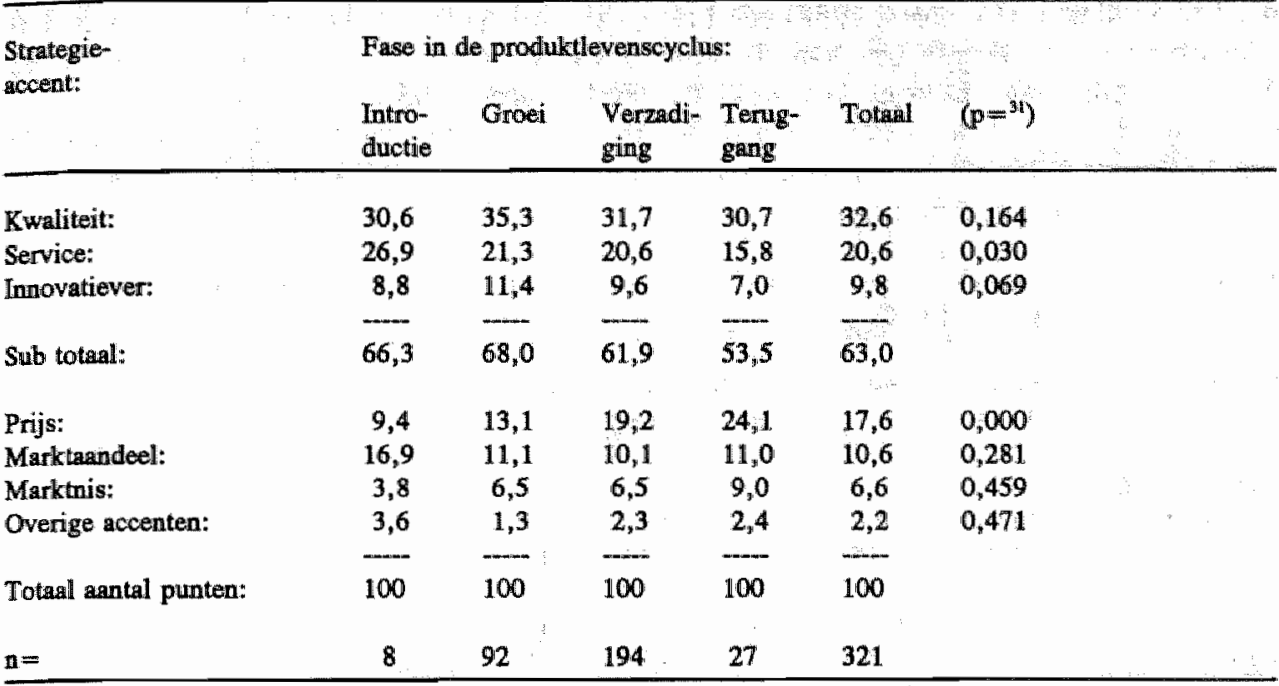

Uit het empirisch onderzoek (tabel 5.2.) blijkt dat in de verzadigingsfase het aantal PKV'n lager is dan in met name de groeifase. In de groeifase zijn door $26 \%$ van de ondernemingen én tot en met vier PKV'n doorgevoerd; in de verzadigingsfase door bijna $40 \%$. In de teruggangsfase is van een lager aantal PKV'n weinig te bespeuren. Het percentage ondernemingen dat meer dan 20 (of continu) PKV'n heeft aangebracht is echter wel enigszins lager ( $21 \%$ versus $25 \%$ ). Bij toetsing van hypothese A1 blijkt dat er enige aanwijzing is dat het aantal PKV' $n$ in de introductie- en groeifase groter is dan in de verzadigings- en teruggangsfase ${ }^{32}$.

\subsection{Selectie van een produkt/markt combinatie}

Robinson (1988) concludeert dat de reactie-intensiteit niet verschillt tussen industriële markten en consumentenmarkten (vergelijk hypothese B4). Het is echter zeer wel mogelijk dat de aard van de reactie verschilt. Bijvoorbeeld, toetredingen in de voedingswarensector (of meer algemeen de "fast moving consumer goods") zullen waarschijnlijk intensiever worden beantwoord met prijs en promotie-instrumenten dan toetredingen in markten voor duurzame industrële goederen. Daarnaast zal vermoedelijk 321 van de 384 ondememingen beantwoordden beide vragen.

Op basis van F-toets voor werschillen tussen de vier fasen in de produktlevensicyclus.

Op basis wan toetsing van de introductie- en groeifase versus de verzadigings- en teruggangsfase blijkt dat $\chi=10,18 / \mathrm{df}=6, p=0,117$ bij $n=329$. Daarbij heeft $65 \%$ vain de ondernemingen met het produkt in de introductie- en groeifase vijf of meer PKV'n doorgevoerd, tegenover $48 \%$ van de ondernemingen in de verzadigings- en teruggangafase.
} 
in het geval van PKV'n de aard van de kenmerken van het produkt een rol spelen (vergelijk Garvin 1984b). In wergelijkbaar onderzoek blijkt dat toetredingsstrategieên bij markttoetredingen (Robinson 1988) een belangrijke rol spelen als het gaat om reacties van concurrenten. De kenmerken van de soort PKV verschillen tussen duurzame en nietduurzame goederen. Daaruit kan wellicht worden geconcludeerd dat het zinvol is een onderscheid te maken tussen industriële en consumentenmarkten. Enerzijds om de conclusie van Robinson te verifiëren en anderzijds om de mogelijke invloed van de soort PKV in de analyse te betrekken.

Tabel 5.2.: $\quad$ Fasen in de produkllevenscyclus en frequentie van de PKV'n in een periode van vijf jaxar $(1983-1987)^{33}$.

\begin{tabular}{|c|c|c|c|c|c|}
\hline Fuse PLC: & $\begin{array}{l}\text { Intro- } \\
\text { ductive }\end{array}$ & Groei & $\begin{array}{l}\text { Verzadi- } \\
\text { ging }\end{array}$ & $\begin{array}{l}\text { Terug- } \\
\text { gang }\end{array}$ & Totalal \\
\hline Aantal PKV': & & & & & \\
\hline Gaen PXV: & $20,0 \%$ & $9,0 \%$ & $12,8 \%$ & $4,2 \%$ & 37 \\
\hline 1-2: & $20,0 \%$ & $11,0 \%$ & $16,9 \%$ & 8,3 & 48 \\
\hline 34: & $0,0 \%$ & $15,0 \%$ & $23,6 \%$ & $29,2 \%$ & 68 \\
\hline 5-6: & $0,0 \%$ & $21,0 \%$ & $10,8 \%$ & $25,0 \%$ & 48 \\
\hline $7 \% 10$ & $10,0 \%$ & $11,0 \%$ & $9,2 \%$ & $4,2 \%$ & 31 \\
\hline $10-20$ & $0,0 \%$ & $8,0 \%$ & $3,1 \%$ & $8,3 \%$ & 16 \\
\hline$>20$ of continu: & $50,0 \%$ & $25,0 \%$ & $23,6 \%$ & $20,8 \%$ & 81 \\
\hline $\mathrm{n}=$ & 10 & 100 & 195 & 24 & 329 \\
\hline
\end{tabular}

Omdat het onze intentie is een algemeen beeld te schetsen van het reactiegedrag, is het onderzoek niet gericht op specifieke produktcategorieën of branches (zie voor een vergelijkbare onderzoeksmethodologie Schoeffler 1977). In ons onderzoek is gekozen voor een relatief homogene groep bedrijven met betrekking tot de markt (wie is de klant?) en het produkt (welk type produkt?), namelijk industriële markten en duurzame goederen. Een ander argument om voor deze produkt/markt combinatie te kiezen is het feit dat de indeling naar soorten PKV'n van Garvin (1984b) niet geschikt is om PKV'n anders dan van duurzame goederen te beschrijven.

Tot slot blijken, wanneer de restgroep van ondernemingen als referentiegroep wordt gebruikt, er enkele wezenlijke verschillen tussen de twee groepen te bestaan (vooruitlopend op de resultaten in hoofdstuk 6).

De restgroep kan worden omschreven als bedrijven met niet-duurzame goederen (of diensten) en industriële markten of als bedrijven die opereren op consumentenmarkten (zie ook tabel 5.3. en figuur 5.1.). Van de 384 bedrijven behoren er 237 tot de markt van duurzame goederen en industriële markten (ID-groep) en 147 tot de restgroep, die overwegend uit bedrijven bestaat die opereren op consumentenmarkten met niet-duurzame goederen (CND-groep). In de volgende paragraaf worden de profielen van de twee produkt/markt-combinaties met elkaar vergeleken. Het empirisch onderzoek in hoofdstuk $7 \mathrm{zal}$ zich vervolgens richten op de ID-groep. 


\begin{tabular}{|c|c|c|c|}
\hline $\begin{array}{l}\text { D-groep } \\
\text { Produkt }\end{array}$ & $\begin{array}{l}\text { Percentage van de } \\
\text { ondernemingen }\end{array}$ & Markit & $\begin{array}{l}\text { Percentage van do } \\
\text { ondernemingen }\end{array}$ \\
\hline Duurzaam: & $100 \%$ & Industriele: & $100 \%$ \\
\hline $\begin{array}{l}\text { CND-groep } \\
\text { Produkt }\end{array}$ & $\begin{array}{l}\text { Percentage van de } \\
\text { ondernemingen }{ }^{34}\end{array}$ & Markt & $\begin{array}{l}\text { Percentage van de } \\
\text { onderneimingen ts }\end{array}$ \\
\hline $\begin{array}{l}\text { Niet-duurzagm: } \\
\text { Duurzaam: } \\
\text { Dienst (service): }\end{array}$ & $\begin{array}{l}59,9 \% \\
30,6 \% \\
13,6 \%\end{array}$ & $\begin{array}{l}\text { Consumenten: } \\
\text { Consurmenten via } \\
\text { distribuanten: } \\
\text { Industrièle: }\end{array}$ & $\begin{array}{l}32,0 \% \\
54,4 \% \\
36,1 \%\end{array}$ \\
\hline
\end{tabular}

Figuur 5.1.: Afbakening van de ID-groep en de CND-groep.

\begin{tabular}{|c|c|c|}
\hline Markt & Industrie & Consument \\
\hline Duurzaam & ID-groep & CND-groep \\
\hline Niet duurzaam & CND-groep & CND-groep \\
\hline
\end{tabular}

\subsection{Profielen van de ID-groep en de CND-groep ${ }^{36}$}

De ID-groep bestaat uit 237 ondernemingen, met een gemiddeld marktaandeel in de door henzelf afgebakende markt van ruim $24 \%$. Ruim $2 / 3$ van deze ondernemingen heeft een marktaandeel van $25 \%$ of lager. Het gemiddeld aantal concurrenten is 34 , waarbij ruim $69 \%$ van de ondernemingen 10 of minder concurrenten percipieert. Het belangrijkste produkt wan de meeste bedrijven $(60 \%)$ bevindt zich in de verzadigingsfase van de produktlevenscyclus. In de marketing-strategie liggen de belangrijkste accenten op kwaliteit (gewicht van 33 punten van de 100), service (20) en prijs (19). 64\% van de bedrijven rapporteert dat het in hun branche gebruikelijk is dat de produktkwaliteit regelmatig wordt aangepast. Verder is de omzet en het netto bedrijfsresultaat van de ondememingen in 1986 bekend. $14 \%$ van de ondernemingen heeft een omzet (excl. BTW) van meer dan 100 miljoen gulden; $39 \%$ een omzet van minder dan 10 miljoen gulden.

34. Per onderneming meer dan Gén antwoord mogelijk.

35. Per onderneming meer dan cén antwoord mogelijk.

36 Voor exacte gegevens wordt verwezen naar bijlage $\mathrm{E}$, waarin de rechte tellingen van de vragen zijn opgenomen. 
Het netto bedrijfsresultaat is voor $12 \%$ van de ondernemingen negatief.

Ten aanzien van thet aantal PKV'n in de periode $1983-1987$ blijkt dat $7,6 \%$ van de ondernemingen geen enkele keer een PKV heeft doorgevoerd. Tot slot blijkt dat in de teruggangsfase van de PLC de ondernemingen minder gewicht toekennen aan service en innovatiever zijn dan in de andere fasen van de PLC (23\% versus 30-33\%) en dat er in de latere fasen van de PLC een sterke nadruk ligt op prijsconcurrentie.

De CND-groep bestaat uit 147 ondernemingen, met een gemiddeld marktaandeel van bijna $17 \%$. Bijna $80 \%$ van de ondernemingen heeft een marktaandeel van $25 \%$ of lager. Het gemiddeld aantal concurrenten bedraagt 67 , waarbij $65 \%$ van de ondememingen 10 of minder concurrenten percipieert. Het belangrijkste produkt van de meeste bedrijven $(57 \%)$ bevindt zich in de verzadigingsfase van de produktlevenscyclus. In de marketingstrategie liggen de belangrijkste accenten op kwaliteit (32), service (21) en prijs (16). Voor $56 \%$ van de bedrijven is het gebruikelijk in de branche waarin zij opereren dat de produktkwaliteit regelmatig wordt aangepast. $20 \%$ van de bedrijven heeft een omzet van meer dan 100 miljoen gulden; $36 \%$ een omzet van minder dan 10 miljoen gulden. Het netto bedrijfsresultaat is voor $15 \%$ van de ondernemingen in 1986 negatief.

Ten aanzien van het aantall PKV'n blijkt dat ruim $16 \%$ van de ondernemingen in de periode 1983-1987 geen PKV heeft doorgevoerd. Tot slot blijkt dat in de teruggangsfase van de PLC de ondernemingen minder gewicht toekennen aan service en innovatiever zijn dan in andere fasen van de PLC (23\% versus $31-38 \%$ ). In de latere fasen van de PLC ligt een sterkere nadruk op prijsconcurrentie en met name in de introductie- en teruggangsfase wordt een groter gewicht toegekend aan het streven naar een groter marktaandeel.

Worden de ID-groep en de CND-groep met elkaar vergeleken dan blijkt dat de profielen weinig van elkaar verschillen. Statistisch significante ${ }^{37}$ verschillen treden op bij het gemiddelde marktaandeel en het accent op het behaien van een zo hoog mogelijk marktaandeel in de marketing-strategie. De CND-groep heeft een lager marktaandeel $(16,5 \%$ versus $24,1 \%)$, en legt een hogere nadruk op het verwerven van een groter marktaandeel als onderdeel van de marketing-strategie (gewicht 12,4 versus 9,9). Relatief hoge marktaandelen zijn dus te vinden in de ID-groep waarin zich industriële bedrijven bevinden die veelal een marktnis bewerken en als zodanig ook cen afgebakende markt percipiëren, waarin zij een redelijk groot marktaandeel bezitten. Ondernemingen in de CND-groep bewerken veelal massa consumentenmarkten, waardoor de nadruk op het behalen van een zo hoog mogelijk marktaandeel verklaarbaar is. Het aantal bedrijven zonder PKV'n in de periode $1983-1987$ is kleiner in de ID-markt $(7,6 \%$ versus $16,1 \%$ voor de CND-markt).

Op basis van deze gegevens kan worden geconcludeerd dat de groepen weinig verschillen ten aanzien van de externe omgeving, de marketing-strategie en de ondernemingskenmerken. In het algemeen hebben ondernemingen in de CND-groep een groter marktaandeel, en is het behalen van een hoger marktaandeel een belangrijker onderdeel van de marketing-strategie. Het aantal ondernemingen dat in een periode van vijf jaar géén PKV heeft doorgevoerd is groter (absoluut en procentueel) bij de CNDgroep dan bij de ID-groep. 


\subsection{Conclusies}

In de marketing-strategie krijgt kwaliteit het hoogste gewicht, gevolgd door service en prijs. Samen verkrijgen deze drie thema's $72 \%$ het totaal aantal te verdelen punten. Kwaliteit krijgt het hoogste gewicht in elke fase van de PLC, en er is geen statistisch significant verschil in dat opzicht tussen de fasen van de PLC. Met name in de eerste fasen van de PLC ligt er een meer dan evenredige nadruk op service en "innovatiever" zijn, en in de latere fasen van de PLC op prijsconcurrentie.

Deze conclusies blijken overeen te komen met de eerder genoemde bevindingen (Wasson 1978, Leeflang 1987) dat verschillende marketing-strategieën geëigend zijn voor verschillende fasen van de PLC. In met name de introductiefase kan er sprake zijn van technische problemen, waardoor service (probleemoplossing) een belangrijk element in de marketing-strategie is. In de verzadigings- en teruggangsfase groeit de markt niet meer en is het produkt, qua ontwikkeling, uitgekristalliseerd. De concurrentie wordt daardoor gevoelig voor prijsconcurrentie (Staples, Baker \& Sweeney 1976, Wasson 1978).

Er is enig bewijs voor het accepteren van de hypothese dat er meer PKV' $n$ in de introductie- en groeifase van de PLC voorkomen dan in de verzadigings- en teruggangsfase (Hypothese A1). PKV'n komen in elke fase van de produktlevenscyclus voor. Met name in de verzadigingsfase worden minder vaak PKV'n geïnitieerd en in de groeifase komen weer relatief veel PKV'n voor.

Tot slot kan op basis van de gegevens worden geconcludeerd dat in ons onderzoek de IDen CND-groep weinig verschillen ten aanzien van de externe omgeving, de marketingstrategie en de ondernemingskenmerken. In het algemeen hebben ondernemingen in de CND-groep een groter marktaandeel, en is het behalen van een hoger marktaandeel een belangrijker onderdeel van de marketing-strategie. Het aantal ondernemingen dat in een periode van vijf jaar gén PKV heeft doorgevoerd is groter bij de CND-groep (absoluut en procentueel) dan bij de ID-groep.

In het volgende hoofdstuk (hoofdstuk 6) worden de resultaten uit het empirische onderzoek met betrekking tot PKV'n en concurrentiële reacties besproken. Eerst zullen de verschillen tussen de ID- en CND-groep worden geanalyseerd, waarna in detail wordt ingegaan op PKV' $n$ in de ID-groep (in hoofdstuk 7). Daar wordt ook verder beargumenteerd waarom wij ons op de industriële ondernemingen richten. 



\section{Resultaten van het empirisch onderzoek in grote lijnen}

In dit hoofdstuk zullen de resultaten van het empirisch onderzoek naar de aanleidingen voor PKV'n, PKV'n en reacties voor de gehele groep van 384 bedrijven worden gepresenteerd. Uitgangspunt is, zoals aangegeven in hoofdstuk 4, de perceptie van de managers. Vervolgens wordt een vergelijking gemaakt tussen de twee produkt/marktcombinaties die in het vorige hoofdstuk zijn gedefinieerd. Eerst wordt in paragraaf 6.1. aandacht besteed aan de aanleidingen voor een PKV, de reacties van concurrenten en het gepercipieerde resultaat. Dit betreft dan resultaten voor de totale groep van ondernemingen. Paragraaf 6.2 . behandelt gedetailleerder de uitkomsten voor de afzonderlijke produkt/marktcombinaties, waarbij tevens hypothese B3 wordt getoetst. De overige hypothesen zullen worden getoetst in hoofdstuk 7 . Bijlage $F$ bevat de gedetailleerde uitkomsten voor zowel de totale groep van ondernemingen als de ID- en $\mathrm{CND}$-groep. Tot besluit van deze globale resultaten wordt in paragraaf 6.3. een aantal voorlopige verklaringen voor en interpretaties van de resultaten gegeven.

6.1. Aanleidingen voor PKV'n, reacties van concurrenten en gepercipieerde resultaat: de totale groep van ondernemingen

In deze paragraaf worden de uitkomsten voor de totale groep van 384 ondernemingen besproken. Achtereenvolgens worden de aanleidingen (6.1.1.), de reacties (6.1.2.) en gepercipieerde resultaten (6.1.3.) besproken. Tot slot volgen de conclusies $(6.1 .4$.$) .$

\subsubsection{Aanleidingen voor PKV' $\mathrm{n}^{38}$}

In het totaal hebben 314 ondernemingen die een PKV hebben beschreven eén of meer aanleidingen aangegeven voor deze PKV. De belangrijkste reden om de kwaliteit van een produkt te verbeteren, is het signaal uit de markt (81\%). Deze signalen zijn vooral gebaseerd op wensen van klanten of gebruikers, ofwel op basis van uitingen van ontevredenheid. Een groot aantal ondernemingen vindt ook een aanleiding in de eigen capaciteit of mogelijkheden binnen het bedrijf $(60 \%)$. Deze liggen vooral in technische mogelijkheden, maar ook in organisatieveranderingen of de beschikbaarheid van kapitaal. Bij 39\% van de PKV'n wordt de concurrentie genoemd als aanleiding voor de PKV'n. Meestal is dit ook een PKV bij de concurrentie. Anders geïnterpreteerd geeft dit cijfer tevens weer dat PKV'n van de concurrentie (mede)bepalend zijn voor concurrentiële reacties met PKV' $n$. De concurrentie speelt dus een niet onaanzienlijke rol bij beslissingen om de kwaliteit van produkten te verbeteren. In $20 \%$ van de gevallen zijn het derden (de overheid, belangenorganisaties van consumenten of het streven naar certificatie) die een aanleiding zijn tot het verbeteren van de produktkwaliteit. 


\subsubsection{Reacties van concurrenten op PKV' $n^{39}$}

Allereerst is het denkbaar dat sommige concurrenten niet reageren op een PKV. Reacties kunnen plaatsvinden met verschillende instrumenten van de marketing-mix. De belangrijkste concurrent kan reageren met eén instrument, maar ook met een samenstel van instrumenten tegelijk. Verder is de snelheid en intensiteit van de reactie van belang. In totaal werd de vraag naar reacties door 306 ondernemingen beantwoord. Bijna $70 \%$ van de ondernemingen rapporteerden een reactie van een concurrent met één of meer instrumenten. Uitgaande van de groep van 214 ondernemingen die een reactie van de concurrent bemerkten, heeft die reactie in $73 \%$ van de gevallen betrekking op het produkt en in $13 \%$ van de gevallen op de service rond het produkt (produkt plus). In $28 \%$ van de gevallen reageert de concurrent met het ontwikkelen van een nieuw produkt of een toevoeging aan het assortiment. Een reactie met de prijs of in de sfeer van promotie wordt in beide gevallen in $37 \%$ van de PKV'n waargenomen. Reacties op het terrein van de distributie spelen een ondergeschikte rol. Slechts in vier gevallen wordt een reactie ten aanzien van distributie vermeld:

De intensiteit van de reactie (het aantal reactie-instrumenten dat wordt gehanteerd) is gemiddeld 1,8. De gemiddelde reactiesnelheid is 9,8 maanden.

\subsubsection{Het gepercipieerde resultaat van PKV' $\mathbf{n}^{40}$.}

Het gepercipieerde resultaat van de PKV is gemeten met behulp van de door de manager geschatte invloed op het marktaandeel (lager, gelijkblijvend, enigszins hoger, beduidend hoger) en op het netto resultaat van de onderneming (geen verbetering, wel verbetering). In $71 \%$ van de gevallen wordt een hoger marktaandeel gepercipieerd en bij $58 \%$ van de ondernemingen een verbeterd financieel resultaat. Zowel een hoger marktaandeel als een beter financieel resultaat wordt aangegeven door $52 \%$ van de onderzochte ondernemingen.

\subsubsection{Conclusies}

In het onderzoek zijn vier groepen redenen onderscheiden die beschouwd kunnen worden als aanleiding voor een PKV. In de praktijk blijkt dat zij ook daadwerkelijk voorkomen. De mate waarin zij voorkomen, verschilt aanzienlijk.

PKV'n worden vooral doorgevoerd naar aanleiding van signalen uit de markt. Signalen van klanten en gebruikers (81\%) komen twee maal zoveel voor als "signalen van concurrenten" (40\%). Ontwikkelingen binnen het eigen bedrijf bieden ook vaak (60\%) de mogelijkheden tot een PKV; het gaat hierbij dan veelail om technische mogelijkheden. PKV'n worden relatief weinig geïnitieerd door derden.

Tevens blijkt dat een niet onbelangrijk deel van de PKV'n een reactie is op een PKV bij een concurrent. Dit komt voor bij $30 \%$ van de onderzochte ondernemingen. Ten aanzien van het actie-reactie patroon op en met PKV' $n$ is het volgende, meer gedetailleerd, vast te stellen.

In lets meer dan 30\% van de PKV'n wordt door de belangrijkste concurrent in het geheel

Zie voor de frequentieverdeling van de soorten reacties tabel F.2.a. in bijlage F, en voor de renctie-intensiteit en snellheid tabel F.2.b. 
niet gereageerd. Dit betekent dat $70 \%$ wel reageert. Van deze groep concurrenten geeft wervolgens $65 \%$ aan dat hun reactie in ieder geval ook uit een PKV bestaat; een PKV die weelal gepaard gaat met nog andere veranderingen in de marketing-mix. Als deze getallen met elkaar vermenigvuldigd worden, kan geconstateerd worden dat minimaal $45 \%$ van de belangrijkste concurrenten die reageren op een PKV ook met een PKV reageert.

In het totale reactiepatroon van concurrenten blijkt zeer veel gebruik gemaakt te worden wan reacties via het produkt. De omvang hiervan is ongeveer tweemaal zo groot als prijsof promotie-reacties. Gemiddeld reageert men met 1,8 instrumenten. De snellheid waarmee gereageerd wordt, is gemiddeld 9,8 maanden.

Als resultaat van de geīnitieerde PKV meent iets meer dan de helft van de ondernemingen dat zowel het financieel resultaat als het marktaandeel zijn gestegen. In jets meer dan de helft van de ondernemingen is een PKV in deze twee opzichten dus succesvol.

6.2. Aanleidingen voor $P K V$ " $n$, reacties van concurrenten en gepercipieerde resultaat: verschillen tussen de ID- en CND-groep ${ }^{41}$.

In deze paragraaf wordt aangeven in hoeverre er sprake is van verschillen in aanleidingen voor PKV'n tussen de twee onderscheiden produkt/markt combinaties (6.2.1.). Daarna wordt aangeven of en zo ja, in hoeverre de soort reactie, de reactie-intensiteit en snelheid van reageren (6.2.2.) van ondernemingen in de voor het onderzoek geselecteerde IDgroep afwijkt van de CND-groep. Daarin zal eveneens hypothese B3 worden getoetst, waarin gesteld wordt dat de intensiteit van de reactie tussen industriële markten en consumentenmarkten niet verschilt. Tot slot wordt aandacht besteed aan het verschil in het gepercipieerde resultaat $(6.2 .3$.) en worden de conclusies geformuleerd (6.2.4.).

\subsubsection{Aanleidingen voor PKV' $n$ in de ID- en CND-groep}

In deze paragraaf wordt aandacht geschonken aan de verschillen in aanleidingen voor PKV'n tussen de twee produkt/markt combinaties. De in het vorige hoofdstuk gepresenteerde indeling in ID- en CND-groep wordt hierbij gehanteerd.

Van de ID-groep hebben 206 van de 237 ondernemingen eén PKV beschrevèn die zij hebben aangebracht in de afgelopen vijf jaar. De belangrijkste motieven om een PKV door te voeren waren gelegen in markt-"pull" en organisatie-"push" redenen, namelijk de wensen van de afnemers en de technische mogelijkheden van de onderneming zelf. Respectievelijk ruim $54 \%$ en bijna $54 \%$ van de ondernemingen gaven deze motieven aan. Een niet onbelangrijk deel $(31 \%)$ van de ondernemingen noemde kwaliteitsverbeteringen bij de concurrentie als impuls de produktkwaliteit te verbeteren.

Van de CND-groep hebben 111 van de 147 ondernemingen een PKV beschreven. De belangrijkste aanleidingen waren ook hier de wensen van de afnemers en de technische mogelijkheden van het eigen bedrijf met respectievelijk $53 \%$ en $51 \%$. Een andere belangrijke reden was een kwaliteitsverbetering bij de concurrent (26\%). 
De vier rubrieken markt-"pull", organisatie-"push", concurrentie en derden, verschillen niet tussen de ID- en CND-groep. Binnen drie van de vier groepen komen wel enkele saillante verschillen voor (zie tabel 6.1:).

De overall rubriek "marktgeoriënteerde aanleidingen" wordt bij beide groepen even vaak genoemd. De verschillende rubrieken die onder dit begrip vallen komen echter elk áfzonderlijk vaker voor in de ID-groep. Dit houdt in dat het aantal marktgeoriënteerde aanleidingen dat genoemd wordt in de ID-markt groter is dan in de CND-markt.

Tabel 6.1.: Aanleidingen voor de PKV'n (Percentage wan de ondernemingen dat een PKV heeft doorgevoerd).

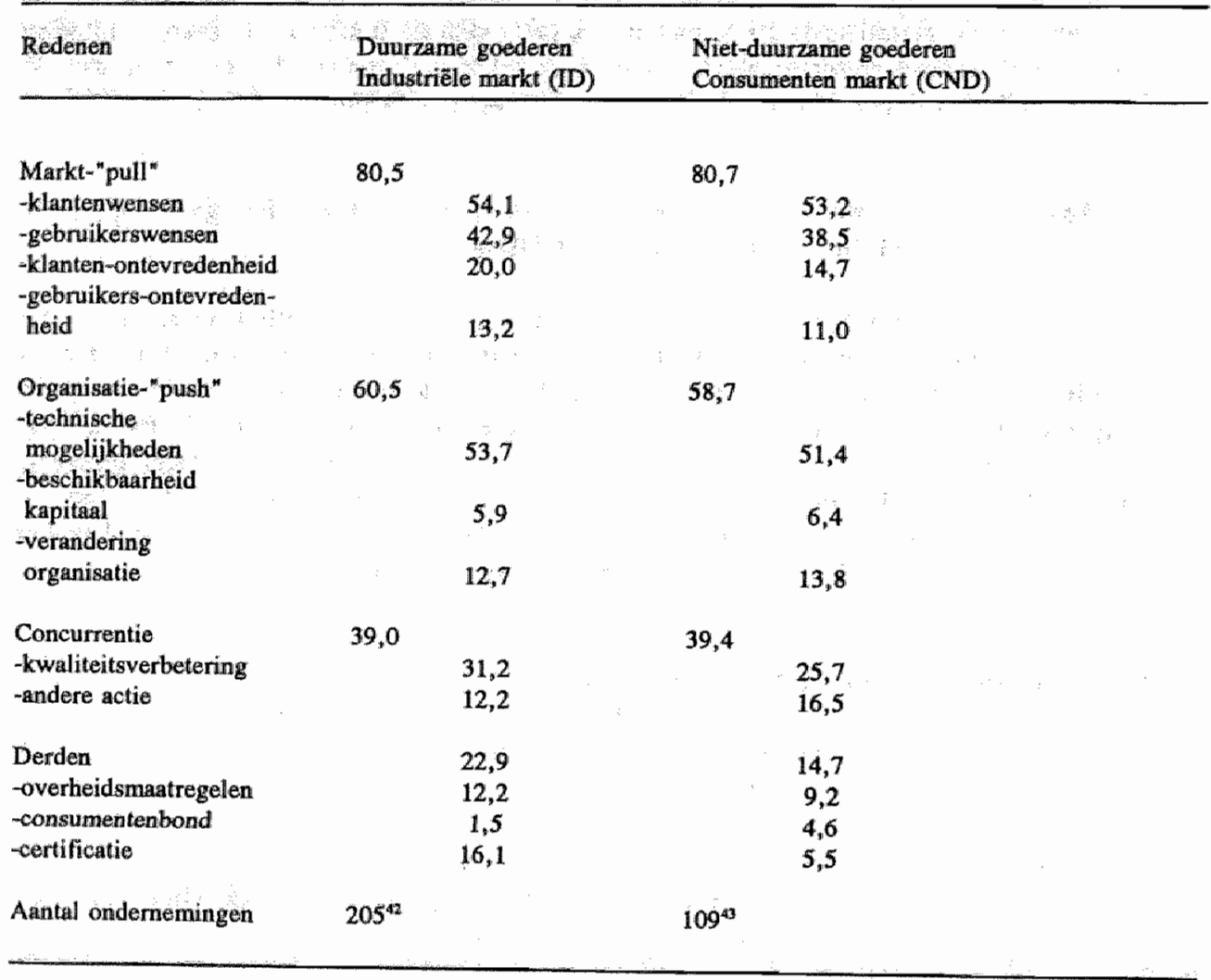

Organisatie-"push" redenen worden bij PKV"n in de ID- en CND-groep even vaak als aanleiding genoemd.

De concurrentie is eveneens voor beide groepen een even belangrijke aanleiding. Binnen deze "concurrentie-rubriek" beschouwt de ID-groep een kwaliteitsverbetering vaker en een andere actie minder vaak als een aanleiding voor een PKV dan de CND-groep.

205 van de 206 ondememingen beantwoordden dexe vraag.

43

109 van de 111 ondernemingen beantwoordden deze vraag. 
Tot slot zijn de aanleïdingen die gerubriceerd zijn onder "derden" voor de ID-groep belangrijker. Met name wordt er bij de ID-groep minder vaak gerefereerd aan consumenteninstanties en vaker aan het voldoen aan certificatie-eisen dan bij de CNDgroep. De onderstaande tabel 6.1. geeft de resultaten in detail weer.

De verschillen tussen ID- en CND-groep zijn niet groot. De belangrijkste verschillen zijn dat PKV'n in de ID-groep vaker gebaseerd worden op certificatie-eisen, kwaliteitsverbeteringen van concurrenten en het grotere aantal signalen uit de markt, dan PKV' $n$ in de CND-groep. De concurrentie is in beide groepen een niet te veronachtzamen factor. Bijna $40 \%$ van de respondenten noemt PKV'n van concurrenten en/of andere acties van concurrenten (mede) een aanleiding om de kwalliteit van het produkt te gaan verbeteren. Dit leidt voor beide produkt/markt-combinaties tot de volgende vijf conclusies:

1) aanleidingen die gekarakteriseerd kunnen worden als "market pull" zijn het belangrijkst voor PKV'n (met name klantenwensen).

2) de organisatie-" push" is eveneens een belangrijke aanleiding voor PKV' $n$.

3) een substantieel deel van de ondernemingen noemt concurrentiële acties een reden om de kwaliteit van het produkt te verbeteren. Met andere woorden de concurrentie speelt ook een belangrijke rol bij beslissingen orm kwaliteit van produkten te verhogen.

4) de groep "derden" speelt de minst belangrijke rol als aanleiding voor een PKV.

5 ) in de twee produkt/marktcombinaties ID en CND is de rol van markt-"pull", organisatie-"push" en de concurrentie als initiërende factor ongeveer even belangrijk. Meer specifiek worden PKV'n in de ID-groep vaker geïnitieerd door certificatie-eisen, kwaliteitsverbeteringen bij concurrenten en een samenstel van enkele signalen uit de markt dan in de CND-groep.

\subsubsection{Verschillen tussen reacties van concurrenten op PKV'n in de ID- en de CND- groep}

Allereerst is het denkbaar dat sommige concurrenten niet reageren op een PKV. Reacties kunnen plaatsvinden met verschillende instrumenten van de marketing-mix. De belangrijkste concurrent kan reageren met één instrument, maar ook met een samenstel van instrumenten tegelijk. Verder is de snelheid en de intensiteit van de reactie van belang. In deze paragraaf komen de verschillen tussen ID- en CND-markt ten aanzien van deze aspecten aan de orde. De basis voor de analyses wordt gevormd door $198 \mathrm{PKV} n$ in de ID-groep en 108 in de CND-groep.

Binnen de ID-groep wordt in bijna $70 \%$ van de gevallen door de belangrijkste concurrent op een PKV gereageerd. Het instrument produkt wordt in de meeste gevallen (78\%) gebruikt om de PKV te pareren. Echter er worden ook andere instrumenten gebruikt, al of niet samen met produktverbeteringen. In ruim $36 \%$ van de gevallen vindt een reactie plaats door middel van het instrument prijs en in $33 \%$, respectievelijk $25 \%$ met een verhoogde promotie-inspanning en de ontwikkeling van een nieuw produkt, of een toevoeging aan het assortiment.

Binnen de CND-groep wordt door ruim $70 \%$ van de ondernemingen een reactie van de belangrijkste concurrent gemeld. De meeste reacties vinden plaats door middel van het 
instrument produkt (in bijna $65 \%$ van de gevallen). In $46 \%$ van de PKV'n wordt met het promotie-instrument gereageerd en in $38 \%$ en $34 \%$ respectievelijk met de prijs en het ontwikkelen van een nieuw produkt of uitbreiding van het assortiment (zie tabel 6.2.).

Tabel 6.2: $\quad$ Reacties van concurrenten met verschillende mirketing-mix instrumenten (Percentage van de respondenten dat het betreffende instrument hanteert)

Reactie

Duurzame goederen Industriele markt (ID)

\section{Totral antall}

ondernemingen:

Rematie met minstens

van de marketing-

instrumenten:

$138(69,7 \%)$

Warvan:

Produlukt:

PKV

-prestaties produkt

-wormgeving

Produkt plius:

-garantilevoonwaarden

-service bij aflevering

-after-stales service

-verkoopvoorwatarden

Nieuw produkt:

-nienw produkt

-assortiment

Promolie:

-promotie/reelame

-verkoopacties

-imigo d m. w. reclame

-verandering merlknam

Prijs:

-prijswerlaging

-prijgverhoging

Distributine:

-distributie

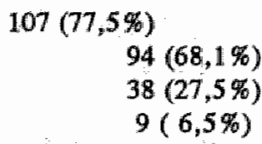

$17(12,3 \%)$

$3(2,29)$

$2(1,4 \%)$

$9(6,5 \%)$

$6(4,3 \%)$

$34(24,6 \%)$

$27(19,6 \%)$

$11(8 ; 0 \%)$

$45(32,6 \%)$

$16(11,6 \%)$

$19(13,8 \%)$

$21(15,6 \%)$

$3(2,2 \%)$

$50(36,2 \%)$

$50(36,2 \%)$

$1(0,7 \%)$

$2(1,4 \%)$
$2(1,4 \%)$
$76(70,4 \%)$

Niet-duurzame goederen Consumentenmarkt (CND)

$108^{4 / 5}$

$49(64,5 \%)$

$44(57,9 \%)$

$13(17,1 \%)$

$4(5,3 \%)$

$11(14,5 \%)$

$3(3,9 \%)$

$2(2,6 \%)$

$5(6,69)$

$3(3,9 \%)$

$26(34,2 \%)$

$16(21,1 \%)$

$15(19,7 \%)$

$35(46,1 \%)$

$14(18,4 \%)$

$20(26,3 \%)$

$15(19,7 \%)$

$3(3,9 \%)$

$29(38,2 \%)$

$25(32,9 \%)$

$4(5,3 \%)$

$2(2,6 \%)$

$2(2,6 \%)$

198 wan de 206 ondernemingen verstrekten informatie over de reactie van de belangrijkste concurrent.

108 van de 111 ondernemingen verstrekten informatie over de reactie van de belangrijkste conciurrent. 
De reacties van concurrenten in de twee groepen verschillen enigszins van elkaar. Ten eerste valt het op dat ten aanzien van reacties met produktverbeteringen bij de ID-groep vaker gereageerd wordt dan bij de CND-groep. Dit geldt zowel voor PKV'n, als voor meer specifiek de prestaties en vormgeving van het produkt. Ten aanzien van produkt plus zijn er geen substantiele verschillen. Nieuwe produkten en met name assortimentsuitbreidingen komen meer voor bij de CND-groep dan bij de ID-groep. Worden de drie categorieën die onder het instrument produkt vallen samen genomen dan blijkt dat er voor het totaal geen verschil in reactie is, maar dat er voor de reactie op onderdelen accentverschillen bestaan.

Reacties met het behulp van het promotie-instrument vinden meer plaats in de CND-groep dan in de ID-groep. Dit geldt ook voor de afzonderlijke promotie-instrumenten.

Opvallend is tenslotte, dat het instrument prijs in de twee groepen in gelijke mate wordt gebruikt om te reageren. In de CND-groep wordt daarbij vaker gebruik gemaakt van een prijsverhoging. Tabel 6.2 . bevat de verschillende reacties met marketing-mix instrumenten op PKV"n in de ID- en CND-groep.

Naast de soort reactie is de intensiteit en de snelheid van de reactie door de belangrijkste concurrent van belang (zie tabel 6.3.).

De intensiteit van de reactie in de ID-groep bedraagt 1,63. Met andere woorden er vindt een reactie plaats met gemiddeld 1,63 instrumenten. Gemiddeld verstrijkt ruim 10 maanden voordat de belangrijkste concurrent daadwerkelijk reageert in de perceptie van de manager.

De intensiteit van de reactie in de CND-groep bedraagt gemiddeld 1,82 instrumenten. De periode die verstrijkt voordat gereageerd wordt, bedraagt gemiddeld ruim 8 maanden.

Tabel 6.3.: Verschil in reactieintensiteit en -snelheid tussen de ID- en de CND-groep (Tussen haakjes de standaarddeviatie $\mathrm{v} / \mathrm{h}$ gemiddelde).

\begin{tabular}{lll}
\hline & $\begin{array}{l}\text { ID-groep } \\
\text { (gemiddeld) }\end{array}$ & $\begin{array}{l}\text { CND-groep } \\
\text { (gemiddeld) }\end{array}$ \\
\hline Reactieintensiteit (aantal instrumenten $^{4}$ ): & $\begin{array}{l}1,63(0,11) \\
\mathrm{n}=198\end{array}$ & $\begin{array}{l}1,82(0,17) \\
\mathrm{n}=108\end{array}$ \\
Reactiesnelheid (antal manden) $^{47}$ : & $\begin{array}{l}10,42(0,83) \\
\mathrm{n}=81\end{array}$ & $\begin{array}{l}8,11(1,10) \\
\mathrm{n}=44\end{array}$ \\
\hline
\end{tabular}

Er is geen statistisch significant $(p>0,10)$ verschil tussen de intensiteit van de reactie in de ID-groep en de CND-groep. Er vanuit gaande dat het grootste deel van de CND-groep bestaat uit ondernemingen die op de consumentenmarkt opereren, kan voorzichtig een conclusie worden getrokken ten aanzien van de reactie-intensiteit in de consumentenmarkt en de industriële markt. Dit houdt in dat Robinsons" hypothese dat er bij markttoe-

Verschil statistisch niet significant met $\mathrm{p}<0,10$.

47 Statistisch significant verschil met $T=1,86, p=0,067$; het aantal watrnemingen is laag vanwege een hoge non-respons op deze vraag. Bij het interpreteren van de witkomsten dient hierme rekening gehouden te worden. 
tredingen geen versehil in reactie-intensiteit te bemerken is tussen een consumentenmarkt en een industrielle markt, eveneens geldt voor PKV'n. Derhalve kan onze hypothese B3: "De reactieintensiteit naar aanleiding van een PKV verschilt niet tussen een consumentenmarkt en een industriële markt", niet worden verworpen.

Er is wel een statistisch significant $(p<0,10)$ verschil tussen de reactietijden waar te nemen. PKV' $n$ in de CND-groep lijken sneller beantwoord te worden door concurrenten dan in de ID-groep.

\subsubsection{Verschil tussen het gepercipieerde resultaat in de ID-groep en de CND-groep} Het gepercipieerde resultaat van de PKV is gemeten met behulp van de door de manager geschatte invloed op het marktaandeel (lager, gelijk, enigszins hoger, beduidend hoger) en op het netto resultaat van de onderneming (geen verbetering, wel verbetering). Ruim $69 \%$ van de ondernemingen in de ID-groep meent dat een hoger marktaandeel en ruim $56 \%$ meent dat een verbetering van het netto resultat als gevolg van de PKV tot stand is gekomen. In de CND-groep daarentegen rapporteert $75 \%$ een marktaandeelverbetering en ruim $61 \%$ een verbetering van het resultaat. Tabel 6.4 . geeft een overzicht van de uitkomsten.

Tabel 6.4.: Gepercipieerde marktaandeelwinst en netto resultaat naar aanleiding van PKV"n.

\begin{tabular}{lcc} 
Giroep & ID-groep & CND-groep \\
\hline Netto resultaat: & & \\
Geen merkbare verbetering: & $84(43,7 \%)$ & $50(38,8 \%)$ \\
Merkbare verbetering netto resultaat: & $108(56,3 \%)$ & $63(61,2 \%)$ \\
& $192(100 \%)$ & $103(100 \%)$ \\
Totale respons: & & \\
Marktaandeel: & $2(1,0 \%)$ & $0(0,0 \%)$ \\
Lager: & $58(29,6 \%)$ & $27(25,5 \%)$ \\
Gelijkblijvend: & $99(50,5 \%)$ & $53(50,0 \%)$ \\
Enigszins hoger: & $37(18,9 \%)$ & $26(24,5 \%)$ \\
Beduidend hoger: & $196(100 \%)$ & $106(100 \%)$ \\
& &
\end{tabular}

$\mathrm{Er}$ is nauwelijks verschil in de percepties van managers ten aanzien van het resultaat van een PKV tussen de ID- en de CND-groep. De ID-groep is iets negatiever over de marktaandeelgroei en het effect op het netto resultaat dan de CND-groep; het verschil is echter niet statistisch significant $(p>0,10)$.

\subsubsection{Conclusies}

In grote lijnen is in de twee produkt/marktcombinaties ID en CND de rol van markt "pull", organisatie-"push" en de concurrentie als initiërendle factor ongeveer even belangrijk.

PKV'n in de ID-groep zijn wel gebaseerd op meer signalen tegelijk uit de markt. Verder is voor de ID-groep een kwaliteitsverbetering van de concurrent een belangrijker 
aanleiding en een andere actie van de concurrent een minder belangrijke aanleiding dan voor de CND-groep.

PKV'n in de ID-groep worden vaker geïitieerd door derden dan PKV'n in de CNDgroep. Met name certificatie-eisen zijn een belangrijker aanleiding in de ID-groep dan in de CND-groep.

De reacties van de belangrijkste concurrenten in de twee groepen verschillen enigszins van elkaar.

Ten eerste valt het op dat ten aanzien van reacties met produktverbeteringen bij de IDgroep vaker gereageerd wordt dan bij de CND-groep. Nieuwe produkten en met name assortimentsuitbreidingen komen meer voor bij de CND-groep dan bij de ID-groep. Reacties met het behulp van het promotie-instrument vinden meer plaats in de CND-groep dan in de ID-groep. Opvallend is tenslotte, dat het instrument prijs in de twee groepen in gelijke mate wordt gebruikt om te reageren.

Er is geen verschil tussen de intensiteit van de reactie in de ID-groep en de CND-groep. Er vanuit gaande dat het grootste deel van de CND-groep bestaat uit ondernemingen die op de consumentenmarkt opereren kan voorzichtig de conclusie worden getrokken dat de reactie-intensiteit naar aanleiding van een PKV niet verschilt tussen een consumentenmarkt en een industriële markt.

Er lijkt wel verschil tussen reactietijden te bestaan. PKV' $n$ in de CND-groep worden sneller beantwoord door concurrenten dan PKV' $n$ in de ID-groep.

Tot slot is er nauwelijks verschil in de percepties van managers ten aanzien van het resultaat van een PKV tussen de ID- en de CND-groep. De ID-groep is iets negatiever over de marktaandeelgroei en het effect op het netto resultaat van PKV'n dan de CNDgroep; het verschil is echter statistisch niet significant.

\subsection{Resultaten en interpretatie van de conclusies}

Aanleidingen voor de ontwikkeling van nieuwe produkten worden voornamelijk gevonden in signalen vanuit de markt (zowel klanten, gebruikers als concurrenten) en de technische mogelijkheden van een onderneming. Bij onderzoek naar het ontwikkelen van nieuwe produkten, blijkt dat de genoemde aanleidingen, en met name de signalen uit de markt, belangrijke verklarende factoren zijn voor het succes van het nieuwe produkt (Von Hippel 1978). In ons onderzoek naar PKV'n blijkt dat meer dan 50\% van de ondernemingen een hoger marktaandeel en een verbeterd resultaat waarneemt. In meer dan de helft van de gevallen is een PKV derhalve markttechnisch en financieel een succes.

PKV' $n$ in de ID-markt worden vaker geỉnitieerd door certificatie-eisen en minder vaak door signalen van consumenteninstanties. Dit ligt voor de hand aangezien certificatie voor veel industriële bedrijven, en met name voor de toeleveringsindustrie, een belangrijk doel is om de marktpositie te versterken. In de CND-groep zijn uiteraard signalen van consumenteninstanties, die hoofdzakelijk consumentenprodukten beoordelen, relatief belangrijk.

In 30\% van de PKV"n wordt door de belangrijkste concurrent niet gereageerd. Dit geldt zowel voor reacties op PKV' $n$ in de ID- als in de CND-groep. Reacties met produktverbeteringen komen bij de ID-groep vaker voor dan bij de CND-groep. Nieuwe 
produkten en met name assortimentsuitbreidingen komen meer voor bij de CND-groep dan bij de ID-groep. In een consumentenmarkt gaat het vaak om assortimenten; die frequent worden aangepast of uitgebreid. Dit kan dan ook relatief eenvoudig en snel geschieden, vooropgezet dat een dergelijke uitbreiding gepaard gaat met promotionele activiteiten. Ook hiervoor bestaat een indicatie: het promotie-instrument is in de CNDgroep een belangrijker reactie-instrument is dan in de ID-groep. In een industriële markt wordt eerder gesproken van produktverbeteringen dan van een nieuw produkt, omdat produkten vaak continu aangepast worden. Een dergelijke aanpassing is vaak maatwerk, en door een relatief beperkt aantal klanten eenvoudiger te communiceren. Derhalve wordt er in de ID-groep waarschijnlijk minder vaak gereageerd met nieuwe produkten en promotionele activiteiten en vaker met produktverbeteringen. In de ID-groep wordt vaker gereageerd met PKV'n. Bovendien is in de ID-groep een PKV van de concurrent een belangrijker aanleiding voor een PKV dan in de CND-groep. Dit leidt tot de conclusie dat in het concurrentieproces PKV'n in de ID-groep wellicht een belangrijker rol spelen dan in de CND-groep. Dit is een reden om voor verdere analyses ten aanzien van de hypothesen onderscheid te maken tussen de ID- en CND-groep.

De reactie-intensiteit verschilt niet tussen de groepen. Er vanuit gaande dat het grootste deel van de $\mathrm{CND}$-groep bestaat uit ondernemingen die op de consumentenmarkt opereren kan voorzichtig de conclusie worden getrokken dat de reactie-intensiteit in consumentenmarkten en in industriële markten niet verschilt.

De concurrentiële reactie is sneller bij de CND-groep, omdat overwegend massa-markten met niet-duurzame ("fast-moving") goederen worden bewerkt. Aangezien deze produkten in het algemeen frequent worden gekocht, is een snelle reactie van de concurrent noodzakelijk. 


\section{De resultaten voor de produktkwaliteitsverbeteringen in de industriële markt van duurzame produkten in detail}

In de volgende analyses staat steeds eén van de drie onderdelen van het model centraal: namelijk $P K V^{\prime} n$, reacties van de concurrent en het gepercipieerde resultaat van de PKV"n. De drie onderdelen worden achtereenvolgens aan de hand van toetsing van de hypothesen behandeld. Zo komen respectievelijk de hypothesen A2, A3 (paragraaf 7.1.), $\mathrm{B} 1, \mathrm{~B} 2, \mathrm{~B} 3$, B5 tot en met B10 (paragraaf 7.2.) en $\mathrm{C} 1$ tot en met $\mathrm{C} 4$ (paragraaf 7.4.) aan de orde. In paragraaf 7.3. wordt meer in detaill ingegaan op de relatie tussen aanleidingen, soorten PKV'n en soorten reacties. De laatste paragraaf $\left(7.5_{n}\right)$ bevat de conclusies.

\subsection{Produktkwaliteitsverbeteringen}

Uit pogingen om de verschillende PKV'n aan de hand van de omschrijvingen in groepen in te delen, blijkt dat PKV'n door een achttal categorieên (vergelijk Garvin 1983) kunnen worden beschreven. Elke PKV kan gekarakteriseerd worden door middel van maximaal twee categorieën ${ }^{48}$. Vervolgens zijn deze acht categorieën zodanig gehercodeerd, dat een driedeling ontstond (zie ook hoofdstuk 4):

1) PKV'n met als benadering het produkt.

2) PKV'n met als benadering het produktieproces.

3) PKV'n met als benadering de gebruiker.

Deze driedeling blijkt in ons empirisch onderzoek niet geheel zinvol; in die zin dat deze indeling van PKV'n niet resulteert in drie elkaar uitsluitende categorieên. Met andere woorden: een aantal PKV'n dient te worden omschreven met behulp van twee van de drie categorieën. Dit levert problemen op bij de analyse van de gegevens. Dit is op te lossen door een vierde categorie te definiëren. Door een vierde categorie "mix" te introduceren kunnen vier elkaar uitsluitende categorieên worden geformuleerd. Deze "mix" bestaat uit al die PKV'n die tot twee categorieën behoren. Dan ontstaan de volgende vier categorieên: PKV'n met als benadering produkt, produktieproces, gebruiker en twee van de genoemde categorieën. De volgende analyses zullen dan ook in eerste instantie gebaseerd zijn op deze vierdeling, waarna - waar mogelijk en zinvol- analyses zullen volgen met behulp van de meer gedetailleerde achtdeling. Daardoor kan getracht worden nog meer informatie uit de gegevens af te leiden.

Tabel 7.1. geeft aan dat de meeste PKV'n bij industriële ondernemingen betrekking hebben op de "performance" van het produkt (55\%), de "conformance" (29\%) en de "durability" (12\%). Op basis van de vier elkaar uitsluitende categorieën blijkt dat de helft van de PKV'n past binnen de produktgerichte benadering van PKV'n; $23 \%$ sluit aan de produktiegerichte benadering en $7 \%$ valt in de gebruikersgerichte benadering. $20 \%$ van de

Zie voor een uitgebreide verantwoording van de indeling in de acht categorieëm bijlage G. 
PKV' $n$ bestaat uit twee van de drie genoemde oriëntaties.

Tabel 7.1.: Verdeling van de soorten PKV' $n$.

\begin{tabular}{lccc}
\hline Categorie-indeling & Vierdeling & Driedeling & Achtdeling \\
\hline $\begin{array}{l}\text { Produkt: } \\
\text { "Performance" }\end{array}$ & $103(50,0 \%)$ & $138(67,0 \%)$ & $114(55,3 \%)$ \\
"Features" & & $17(8,3 \%)$ \\
"Durability" & & $24(11,7 \%)$ \\
Produktie: & & & \\
"Reliability" & $47(22,8 \%)$ & $74(35,9 \%)$ & $15(7,3 \%)$ \\
"Conformance" & & $59(28,6 \%)$ \\
Gebruiker: & & \\
"Serviceability" & $14(6,8 \%)$ & $36(17,5 \%)$ & $11(5,3 \%)$ \\
"Aesthetics" & & $18(8,7 \%)$ \\
"Perceived Quality" & & $8(3,9 \%)$ \\
Mix van soorten: & $42(20,3 \%)$ & & \\
& & & 206 \\
n= & 206 & 206 & \\
\hline
\end{tabular}

De produktlevenscyclus (PLC) kan wellicht een rol spelen bij de verklaring van de soort PKV. In hoofdstuk 5 is gebleken dat accenten van marketing-strategieèn verschillen tussen de fasen van de produktlevenscyclus. In de eerste fasen ligt de nadruk op serviceaspecten, in de latere fasen op concurrerende prijzen. Verder komen PKV'n in de verzadigingsfase minder voor. Deze verschillen in marketing-strategie en frequentie van PKV' $n$ kunnen duiden op verschillende PKV' $n$ in de fasen van de PLC. Afhankelijk van de fase in de PLC kunnen verschillende soorten PKV voorkomen. Hypothese A2 geeft op basis van eerdere hypothese-vorming en onderzoek ten aanzien van de PLC een invulling van de soort PKV, en luidt:

"In de introductie- en groeifase worden relatief veel 'grijpbare' $P K V$ "n gerealiseerd, terwijl in de verzadigingsfase relatief veel 'ongrijpbare' PKV'n gerealiseerd worden".

Op basis van de in tabel 7.2. genoemde gegevens kan allereerst worden vastgesteld dat PKV'n gekenmerkt door twee oriëntaties tegelijk, minder vaak voorkomen naarmate de PLC vordert. In de latere fasen van de PLC komen meer PKV'n voor die te kenmerken zijn door slechts één oriëntatie. Het percentage produktgeoriênteerde PKV"n blijft ongeveer 50 in alle fasen van de PLC. Naarmate de PLC vordert, neemt vooral het percentage produktiegeoriënteerde PKV'n toe. Deze constatering houdt tevens in dat hypothese A3:

"In het begin van de produktlevenscyclus komen vooral PKV'n voor met als uitgangspunt het produkt, en aan het eind van de produktlevenscyclus komen vooral PKV'n voor met als uitgangspunt de produktie ${ }^{m}$, niet kan worden bevestigd. per PKV mogelijk. De vierdeling is gebaseerd op vier elkaar vitsluitende categorieën. 
Tabel 7.2.: Reacties van concurrenten op verschillende soorten kwaliteitsverbeteringen (tussen haakjes staat het van de ondernemingen dat gereageend beeft vermeld), gebaseerd op de Vierdeling

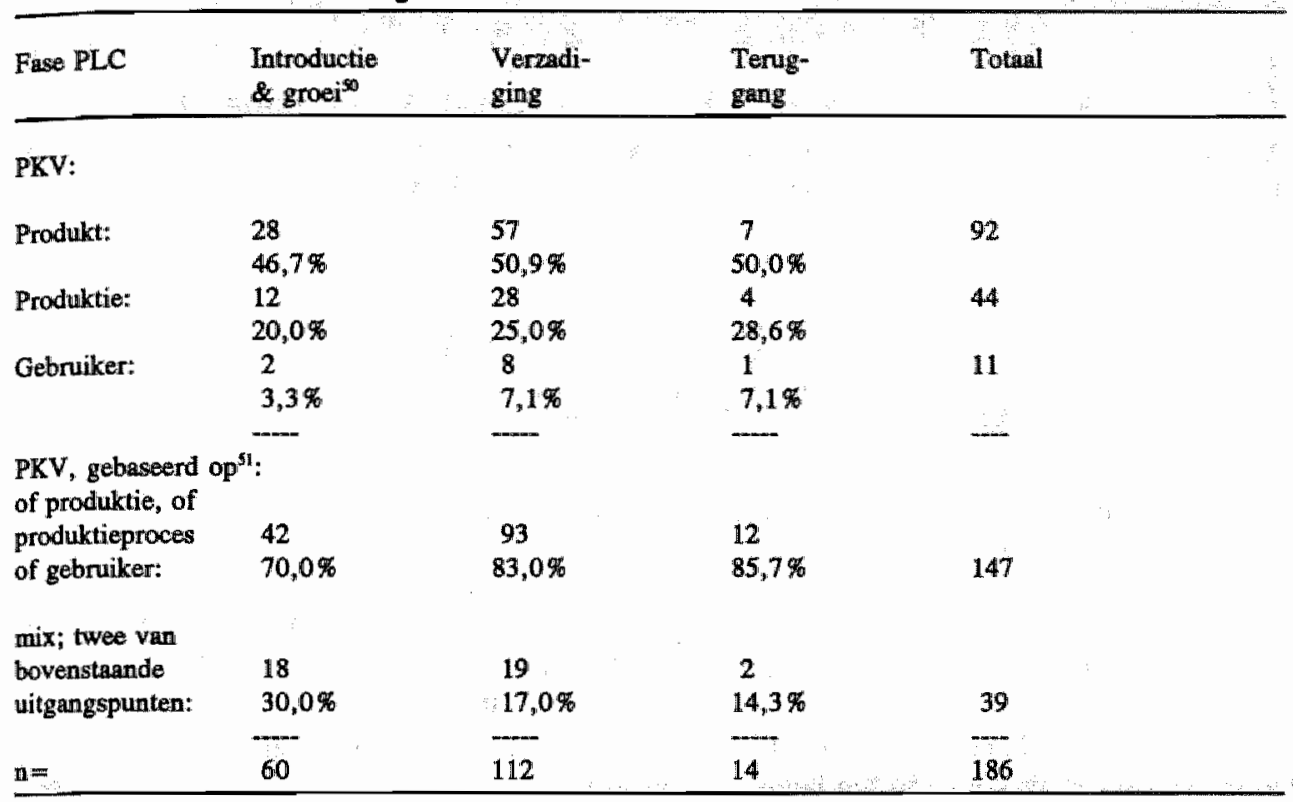

Met bovenstaande indeling is nog geen onderscheid te maken tussen 'grijpbare' en 'ongrijpbare' PKV'n. Als PKV'n door middel van "perceived quality" als typisch 'ongrijpbaar' worden anmerkt en de overige soorten PKV'n als 'grijpbaar' kan een vergelijking, maar nu met de soorten PKV'n aan de hand van de achtdeling mogelijk meer informatie verschaffen. Tabel 7.3. geeft aan dat voor twee van de acht elementen geldt dat zij statistisch significant verschillen tussen de fasen van de PLC. PKV'n mede gekenmerkt door "features" en "serviceability" komen sterker voor in de eerste fasen van de PLC dan in de latere fasen. Tabel 7.3. geeft de bivariate percentages aan van het aantal gevallen per fase in de PLC dat de betreffende soort PKV heeft doorgevoerd. De multivariate analyse, met behulp van variantie-analyse, waarbij de fase in de PLC is opgevat als een interval geschaalde variabele, bevestigt de genoemde resultaten. Derhalve wordt hypothese A2 niet bevestigd.

De soorten PKV"n verschillen statistisch significant tussen de gecombineerde introductie \& groeifase en de verzadigingsfase. Statistische criteria: $x^{2}=6,46 / \mathrm{df}=3, p<0,10$ bij 172 waarmemingen.

Het percentage van de ondernemingen dat een mix-PKV doorvoert verschilt tussen de fasen van de PLC. Gebasseerd op 186 waarnemingen, $x^{2}=4,41 / \mathrm{df}=2$ en $p=0,110$. 


\begin{tabular}{lccccc}
\hline Pase PLC & \multicolumn{1}{l}{$\begin{array}{l}\text { Introduc- Groei } \\
\text { tie }\end{array}$} & $\begin{array}{l}\text { Verzadi- Terug- } \\
\text { ging }\end{array}$ & $\begin{array}{l}\text { Variantie-analyse } \\
\text { (p-waarden) }\end{array}$ \\
\hline PXV: & & & & & \\
& & & & & \\
"performance": & $50,0 \%$ & $\mathbf{4 8 , 2 \%}$ & $58,0 \%$ & $50,0 \%$ & 0,491 \\
"features": & $25,0 \%$ & $14,3 \%$ & $7,1 \%$ & $0,0 \%$ & 0,023 \\
"reliability": & $25,0 \%$ & $10,7 \%$ & $5,4 \%$ & $14,3 \%$ & 0,337 \\
"conformance": & $25,0 \%$ & $33,9 \%$ & $28,6 \%$ & $28,6 \%$ & 0,262 \\
"durability": & $0,0 \%$ & $14,3 \%$ & $10,7 \%$ & $14,3 \%$ & 0,397 \\
"serviceability": & $50,0 \%$ & $7,1 \%$ & $3,6 \%$ & $0,0 \%$ & 0,005 \\
"aesthetics": & $25,0 \%$ & $5,4 \%$ & $9,8 \%$ & $0,0 \%$ & 0,395 \\
"perceived quality": & $0,0 \%$ & $0,0 \%$ & $4,5 \%$ & $7,1 \%$ & 0,232 \\
\hline
\end{tabular}

Als besluit van deze paragraaf kunnen de volgende conclusies worden getrokken.

De PKV'n van industriële ondernemingen zijn vooral te kwalificeren als produkt- of produktiegeoriënteerd. Zij zijn in een vrij beperkt aantal gevallen te kwalificeren als gebruikersgeoriënteerd. Tot de gebruikersgeoriënteerde benadering van PKV'n behoren onder andere "perceived quality" en "serviceability". "Perceived quality"-PKV'n komen vooral voor in de latere fasen van de PLC, en PKV'n aan de hand van "serviceability" komen relatief vaak voor aan het begin van de PLC.

Grosso modo blijkt dat in elke fase van de PLC de produktoriëntatie van de PKV (via primaire en secundaire kenmerken van het produkt en de duurzaamheid) op de helft van de PKV'n van toepassing is. Het aantal van de op de produktie georiënteerde PKV'n neemt enigszins toe in de loop van de PLC; dit betreft vooral de overeenstemming met de specificaties, waardoor de kwaliteit wordt verhoogd.

Gelet op de verschillende aanleidingen voor een PKV door industriële ondernemingen (zie 6.2.4.), blijkt nu dat op grond van de wensen uit de markt, de technische mogelijkheden van de organisatie zelf en de PKV van de concurrentie, de eigen PKV vooral gekenmerkt wordt door verbetering in de primaire kenmerken van het produkt, de duurzaamheid ervan en de overeenstemming met de specificaties. Verbeteringen in secundaire produktkenmerken en serviceverlening lijken meer voor te komen in de eerdere fasen van de PLC. In deze eerdere fasen van de PLC betreffen de PKV' $n$ in veel sterkere mate een veelheid van onderwerpen dan in de latere fasen. In deze latere fasen worden vaker efficiëncyverbeteringen in de produktie aangebracht, leidend tot een kwaliteitsverbetering.

Uitgangspunt is de achtdeling. Gebruikt is een variantie-analyse met de PLC als to verklaren variabele met waarden $1 \mathrm{t} / \mathrm{m} 4$. De totaal verklaarde variantie door de boofdeffecten was significant: $(F=2,186 ; d f=8 / 177 ; p=0,031)$ met significante $p$-waarden voor "features" en "serviceability" van respectievelijk 0,023 en 0,005). Het aantal wamemingen bedroeg 186 . 


\subsection{Reacties van de concurrent}

Eerst worden de reacties van de belangrijkste concurrenten geïnventariseerd $(7.2 .1$.$) .$ Daarna wordt aandacht besteed aan reacties in de verschillende fasen van de PLC (7.2.2.) en wordt de relatie gelegd tussen soorten PKV'n en concurrentiële reacties (7.2.3.). Tot slot wordt de invloed van de marktaandeelwinst als gevolg van een PKV , op de intensiteit van de reactie nader onderzocht $(7.2,4$.$) . De paragraaf wordt afgesloten met een$ multivariate analyse voor de verklaring van de intensiteit van de reactie (7.2.5.). Daarna volgen de conclusies (7.2.6.).

\subsubsection{Inventarisatie van concurrentiële reacties}

De eerste hypothese (B1) luidt:

"De typische reactie van de concurrent op een PKV is geen reactie. Het aantal PKV'n zonder een reactie van de concurrent is groter dan het aantal PKV'n met een reactie van de concurrent".

Het blijkt (zie tabel 7.4) dat in 70\% van de PKV'n een reactie van de belangrijkste concurrent wordt waargenomen. In 30\% van de gevallen volgt er dus geen reactie van de belangrijkste concurrent. De hypothese wordt dus verworpen, omdat het aantal PKV'n met een reactie ruim tweemaal groter is dan het aantal PKV'n zonder concurrentiële reactie.

Hypothese B2 luidt:

"De reactie van de concurrent op een PKV is in de meeste gevallen eveneens een PKV". Het blijkt in ons onderzoek dat bijna $48 \%$ van de belangrijkste concurrenten reageert met een PKV. In iets breder verband blijkt dat ruim de helft $(54 \%)$ van alle concurrenten met eveneens een verbetering van het produkt reageert. Wanneer service-aspecten (produkt plus), assortimentsaanpassingen en nieuwe produkten eveneens worden meegeteld blijkt dat bijna $60 \%$ van de ondernemingen een reactie bemerkt met het marketing-mix instrument produkt. De hypothese wordt dus niet verworpen. De resultaten geven ook aan dat andersoortige reacties substantieel zijn. Bijvoorbeeld in $25 \%$ en $23 \%$ van de gevallen wordt respectievelijk met prijsverlagingen en promotie gereageerd.

In het geval daadwerkelijk wordt gereageerd door de belangrijkste concurrent, dan is produkt veruit $(86 \%)$ het belangrijkste marketing-mix instrument, gevolgd door prijs (36\%) en promotie (33\%). Dit impliceert dat ongeveer $14 \%$ van de belangrijkste concurrenten die daadwerkelijk reageren niet via het produktbeleid reageren.

Ten aanzien van het reageren met de verschillende soorten reactie-instrumenten tegelijk is hypothese B3 opgesteld:

"Voor zover er gereageerd wordt op een PKV door de concurrenten, bestaat deze reactie eerder uit een enkelvoudige reactie dan uit een meervoudige reactie".

Het blijkt dat het aantal instrumenten, waarmee wordt gereageerd varieert van 0 tot 7 . Het maximum aantal instrumenten (in theorie 16 ) bleek 7 te zijn. In $24 \%$ van de gevallen vindt een reactie plaats met cén instrument en in $46 \%$ van de gevallen met meer dan één instrument. Wanneer daadwerkelijk gereageerd wordt, wordt in ongeveer een derde van de gevallen met één instrument gereageerd en door twee derde van de belangrijkste concurrenten met meer dan één instrument: men hanteert dan veelal twee tot drie instrumenten. De hypothese wordt dus niet ondersteund door de resultaten. Immers, het 
aantal meervoudige reacties is groter dan het aantal enkelvoudige reacties. Tabel 7.5 . bevat de resultaten.

Tabel 7.4.: $\quad$ Reacties van concurrenten met de werschillende soorten marketing-mix instrumenten.

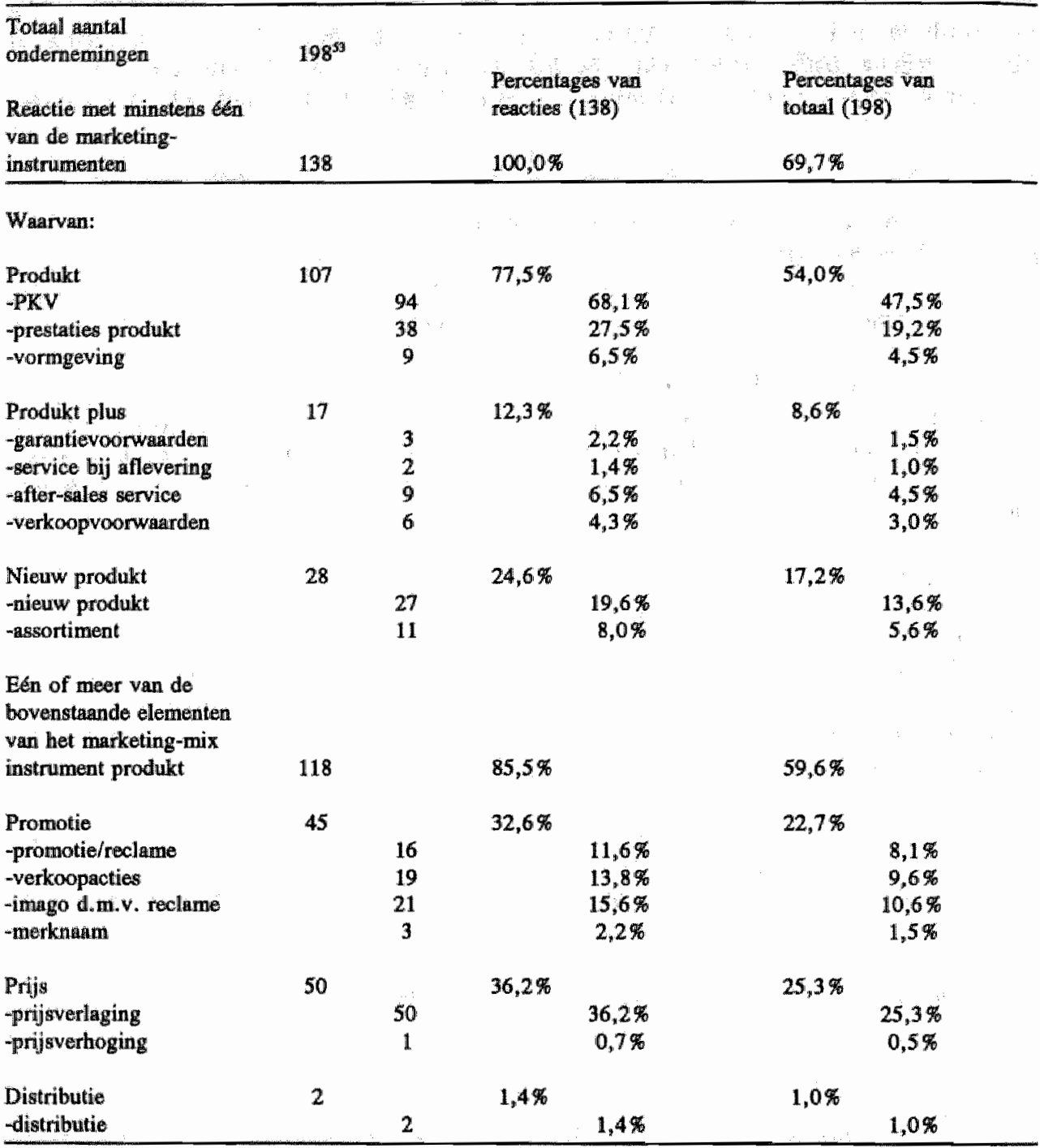
concurnent. 


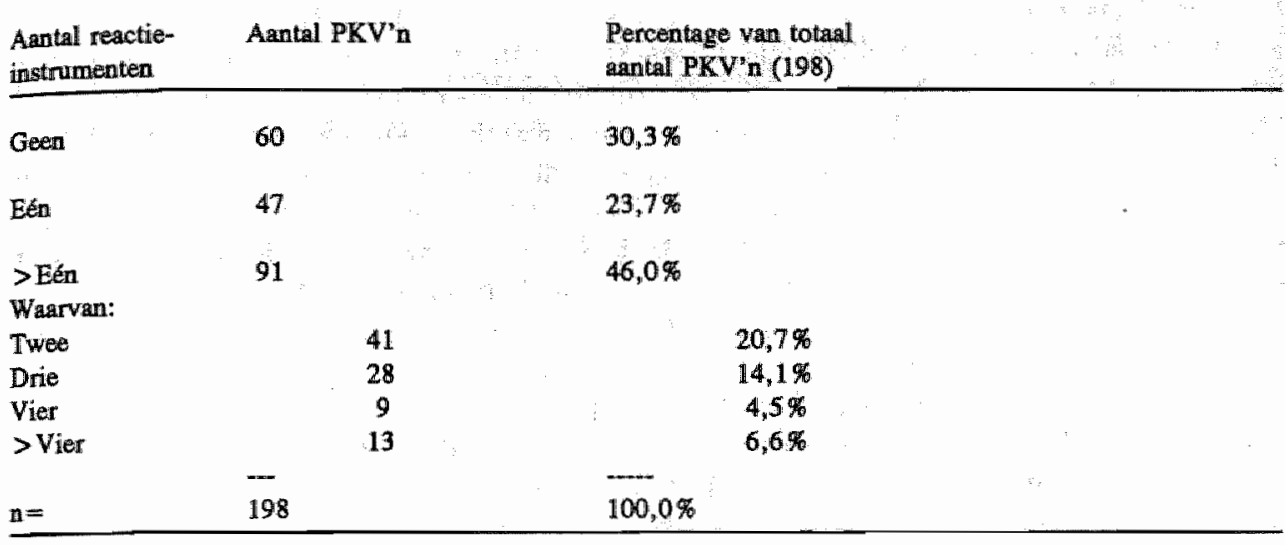

Samenvattend kan worden geconcludeerd dat op PKV'n door de belangrijkste concurrenten wel degelijk wordt gereageerd hoewel in een redelijk aantal situaties ook niet gereageerd wordt. Deze reactie heeft in een meerderheid van de gevallen eveneens te maken met een PKV, en in $86 \%$ van de gevallen met het marketing-mix instrument produkt. De reactie waarin ook de marketing-mix instrumenten prijs en promotie voorkomen is niet onaanzienlijk (respectievelijk 36 en $33 \%$ ). Bij veertien procent van de reacties gaat het niet om het produkt. Vervolgens kan nog geconstateerd worden dat, in geval van een reactie, dit in de meerderheid van de gevallen plaatsvindt met behulp van meer dan één marketing-mix instrument. De typische reactie van de belangrijkste concurrent in de industriële markt is dus een reactie met eveneens het produkt zelve (meestal ook een PKV, gecombineerd met één of twee andere marketing-mix instrumenten).

\subsubsection{Produktlevenscyclus en concurrentiële reactie}

Hypothese B5 luidt:

"In de introductie- en groeifase worden relatief veel "grijpbare" reacties op een PKV gerealiseerd, terwijl in de verzadigingsfase relatief veel "ongrijpbare" reacties op een PKV gerealiseerd worden".

Wanneer per reactie-instrument de toepassing in de vier fasen van de produktlevenscyclus wordt vergeleken kunnen enkele voorzichtige conclusies worden getrokken. Als grenswaarde voor het hier bespreken van de reacties wordt, naast een minimum aantal waarnemingen per reactie-instrument, het criterium $p<0,20$ bij een $x^{2}$-toets ${ }^{54}$ gehanteerd. Om een algemeen beeld te verkrijgen en alle nuances aan te geven is toch gekozen om alle uitkomsten te presenteren die voldoen aan de relatief lage

De in de tahel gepresenteerde p-waarden zijn gebaseerd op een $\chi^{2}$-toets, wairbiji de keuze is gemaakt om alleen die reacties op te nemen met meer dan 12 waarnemingen. In dat gewal is namelijk toen to met behulp van $\chi^{2}$ geoorloofd (Siegel 1956, p. 110). Een tweede criterium is dat slechts significante verschillen tussen reactie-instrumenten (met $p<0,20$ ) zijn opgenomen in het overzicht. 
betrouwbaarheidsdrempel van 0,20 (zie voor een vergelijkbare presentatie van de gegevens Biggadike 1979).

Het blijkt dat er geen verschillen zijn tussen fasen van de PLC ten aanzien van reacties door middel van nieuwe produkten of assortimentstoevoegingen, prijzen en distributie. Met name in de teruggangsfase komen weel minder reacties voor door middel van $P K V$ 'n. Ten aanzien van promotionele aspecten valt op dat in de eerste fase nauwelijks wordt gereageerd met imago-aanpassingen door middel van reclame. De nadruk van imagoreacties ligt op de verzadigingsfase van de PLC. Ten aanzien van hypothese B5 kan worden geconcludeerd dat dergelijke "ongrijpbare" reacties meer voorkomen in de verzadigingsfase van de PLC dan in andere fasen. Echter, ten aanzien van andere meer ongrijpbare reacties (service-aspecten) blijken geen verschillen op te treden tussen de fasen van de PLC. In ons onderzoek komt echter niet naar voren dat meer "grijpbare" reacties plaatsvinden in de introductie- en groeifase van de PLC. De uitkomsten geven derhalve geen aanleiding om hypothese B5 te ontkennen of te bevestigen.

Tabel 7.6:

Soorten concurrentiele reacties in de vier fasen van de produktlevens-cyclus.

\begin{tabular}{|c|c|c|c|c|c|c|}
\hline Fatse PLC: & $\begin{array}{l}\text { Introductie } \\
\text { \& groei }\end{array}$ & $\begin{array}{l}\text { Verzadi- } \\
\text { ging }\end{array}$ & $\begin{array}{l}\text { Terug- } \\
\text { gang }\end{array}$ & 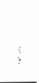 & $\begin{array}{l}\text { Tota: } \\
\mathbf{n}=\end{array}$ & al: \\
\hline Reactie met: & & & $\therefore$ & & & \\
\hline$-P K V$ & $45,8 \%$ & $52,8 \%$ & $21,4 \%$ & & 86 & 0,079 \\
\hline - Verbetering prestaties & $22,0 \%$ & $17,9 \%$ & $0,0 \%$ & & 32 & 0,154 \\
\hline -Nieuw produkt & $18,6 \%$ & 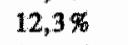 & $0,0 \%$ & & 24 & 0,159 \\
\hline -Imago dum.v. reclamo & $3,4 \%$ & $14,2 \%$ & $7,1 \%$ & & 18 & 0,082 \\
\hline$n=$ & 59 & 106 & 14 & & 179 & \\
\hline
\end{tabular}

Hypothese B6 luidt:

"De intensiteit van de reactie van de belangrijkste concurrent in de verzadigingsfase van de produktlevenscyclus is groter dan in de groeifase".

Deze hypothese kan worden getoetst door per fase in de PLC de gemiddelde reactieintensiteit (RI) te berekenen en te toetsen of deze verschilt tussen de fasen van de PLC. Het blijkt dat er geen statistisch significant verschil in RI is. De RI in de teruggangsfase is evenwel erg laag, in vergelijking met de overige fasen. Uit Scheffe's toets blijkt dat er tussen de RI in de teruggangsfase en de groei-, respectievelijk verzadigingsfase statistisch significante verschillen bestaan. Hypothese B6 wordt echter niet ondersteund omdat er geen verschil in RI geconstateerd is tussen de groei- en verzadigingsfase van de PLC. Tabel 7.7. bevat de resultaten.

Samenvattend kan worden geconcludeerd dat amper verschillen kunnen worden vastgesteld tussen meer grijpbare en meer ongrijpbare reacties op een PKV in de diverse fasen van de PLC. Hooguit kan worden geconcludeerd dat wellicht door de belangrijkste concurrent in de verzadigingsfase meer met een enkele ongrijpbare reactie wordt gereageerd. De RI is significant lager in de teruggangsfase dan in de andere fasen van de
PLC. 


\begin{tabular}{llll}
\hline Fase PLC: & Gemiddelde RI & Standaarddeviatie & $\begin{array}{l}\text { Aantal } \\
\text { waarnemingen }\end{array}$ \\
\hline Introductie \& groei & 1,66 & 1,70 & 59 \\
Verzadiging & 1,71 & 1,64 & 106 \\
Teruggang & 0,64 & 0,74 & 14 \\
Totaal & 1,61 & 1,63 & 179 \\
\hline
\end{tabular}

\subsubsection{Soorten PKV'n en concurrentiële reacties}

Hypothese B7 luidt:

"De soort reactie verschilt, al naar gelang de soort PKV".

In tabel 7.8. wordt voor de soorten PKV'n (op basis van de vierdeling) aangegeven hoe de verdeling is over de verschillende reactiemogelijkheden (op basis van een indeling in groepen: produkt, produkt plus, nieuw produkt, prijs, promotie en distributie). Uitgaande van de vier oriëntaties voor een PKV blijkt dat de belangrijkste concurrenten bij een gebruikersgeoriënteerde PKV relatief veel reageren met prijsverlagingen en met het ontwikkelen van nieuwe produkten naast veranderingen in het produkt zelf. Op een mixgeoriënteerde PKV wordt met een veelheid aan instrumenten gereageerd: zowel via het produkt, als via promotie, prijs en nieuw produkt.

Hypothese B8 luidt:

"De intensiteit van de reactie verschilt, al naar gelang de soort PKV".

Het blijkt dat de intensiteit van de reactie in ons onderzoek verschilt al naar gelang de soort PKV. Met name PKV'n gebaseerd op de gebruiker of een mix-PKV geven aanleiding tot intensieve reacties. PKV'n gebaseerd op produktie geven aanleiding tot de laagste reactie-intensiteit. Deze conclusie wordt ondersteund door additionele analyses met de oorspronkelijke indeling van de PKV' $n$ in acht categorieên, waaruit blijkt dat relatief intensieve reacties voorkomen bij "perceived quality", "features", "reliability", "serviceability" en "performance", terwijl veel minder intensieve reacties bij "conformance" voorkomen. Het verschil in reactie-intensiteit tussen deze soorten PKV'n is groot; namelijk een factor twee. Tabel 7.9. geeft een overzicht van de genoemde bivariate analyse op basis van de vierdeling en multivariate analyses op basis van de achtdeling van soorten PKV'n. 


\section{Soort PKV}

Produkt

Produktie

Reactie-instrument:

\section{Produkt}

Produkt plus

Nieuw produkt

Prijs

Promotie

Distributie

\section{$56,6 \%$}

$8,1 \%$

$16,2 \%$

$21,2 \%$

$19,2 \%$

$1,0 \%$

99

$51,1 \%$
$4,4 \%$
$8,9 \%$
$20,0 \%$
$20,0 \%$
$2,2 \%$

45
Gebruiker

$50,0 \%$
$7,1 \%$
$28,6 \%$
$50,0 \%$
$14,3 \%$
$0,0 \%$

$52,5 \%$

$15,0 \%$

$25,0 \%$

$32,5 \%$

$37,5 \%$

$0,0 \%$

14

40

Tabel 7.9:

Soorten PKV'n en de intensiteit van de reactie, RI (gemiddeld arantal instrumenten).

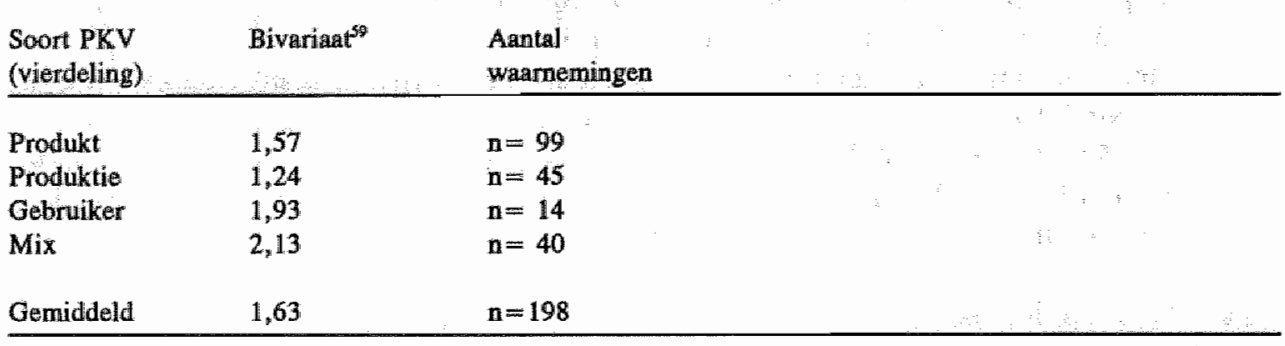

[wervolg tabell 7.9. op volgende pagina]

Gebaseerd op een $\chi^{2}$-toets.

Aantal cellen met een verwacht aantal waarnemingen $<5$ is te groot $(>20 \%)$ en bovendien is de minimale verwachte waarde in cen $<1$. Derhalve is de $\chi^{2}$-toets niet toegepast.

Van de 206 ondernemingen hebben 198 ondernemingen de vraag over de reactie beantwoord.

Statistische criteria: $F=2,39, p=0,070$ bij 198 waarnemingen. Scheffe's toets voor de significantie van parsgewijze gemiddelden laat zien dat het verschil tussen PKV'n op basis van produktie significant verschilt van mix-PKV'n $(p<0,10)$. 
[vervollg tabel 7.9.]

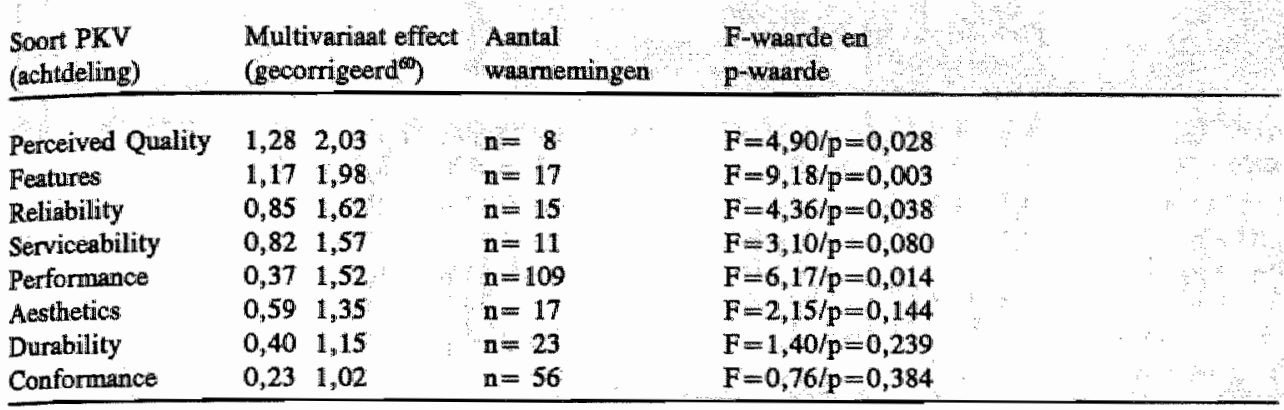

Hypothese B9 luidt:

"De soort PKV is van invloed op de snelheid waarmee de concurrent reageert".

Uit een bivariate analyse blijkt dat op mix-PKV'n het snelst wordt gereageerd (gemiddeld 8,7 maanden). Een multivariate analyse laat echter zien dat dit waarschijnlijk wordt veroorzaakt door de verschillende componenten in de mix. De analyse op basis van de acht oorspronkelijke PKV'n laat zien dat er sneller wordt gereageerd als de PKV (mede) inhoud een verbetering van "durability", "aesthetics", "conformance" en "features". Zie voor de uitkomsten de tabel 7.10..

Tabel 7.10.:

Soorten PKV'n en suelheid van reageren door de concurrent, RS (in maanden).

\begin{tabular}{lll}
\hline $\begin{array}{l}\text { Soort PKV } \\
\text { (vierdeling) }\end{array}$ & Bivariaat $^{61}$ & $\begin{array}{l}\text { Aantal } \\
\text { wamemingen }\end{array}$ \\
\hline Produkt & 10,2 & $\mathbf{n}=40$ \\
Produktie & 11,1 & $\mathbf{n}=11$ \\
Gebruiker & 13,9 & $\mathbf{n}=10$ \\
Mix & 8,7 & $\mathbf{n}=20$ \\
Gerniddeld & 10,4 & $\mathbf{n}=81$ \\
\hline
\end{tabular}

[vervolg tabel 7.10. op volgende pagina]

60

Multiple classificatie-analyse, gebaseerd op de hoofdeffecten van de achtdeling. Telkens is eerst het netto effect (toe- of afname ten opzichte van het gemiddelde) en daarna de gecorrigeerde RI vermeld die slechts betrekking heeft op de betreffende categorie. De gemiddelde $\mathbb{R I}$ lijkt laag ten opzichte van het eerder genoemde gemiddelde van 1,63. Dat gemiddelde is echter gebaseerd op PKV"n, en PKV'n worden in ruim $29 \%$ van de gevallen omschreven met twee cattegorieën. De statistische criteria voor de totale verklaarde variantio zijn: $\mathrm{F}=2,85, \mathrm{p}=0,005$ bij 198 waarnemingen.

Statistische criteria: $\mathrm{F}=1,13$ en $\mathrm{p}=0,341$ bij 81 waarnemingen. Uit paarsgewijze vergelijkingen van gemiddelden met behulp wan Scheffe's toets blijkt ten aanzien wan de reactiesnelheid dat ook paarsgewijs geen statistisch sigmificante verschillen worden opgemerkt $(p<0,10)$. 
[vervolg tabel 7.10.]

\begin{tabular}{|c|c|c|c|c|}
\hline $\begin{array}{l}\text { Soort PKV } \\
\text { (achtdeling) }\end{array}$ & $\begin{array}{l}\text { Multiwariaat effect } \\
\text { (geconrigeer }{ }^{53} \text { ) }\end{array}$ & $\begin{array}{l}\text { Aantal } \\
\text { waramemingen }\end{array}$ & $\begin{array}{l}\text { F-waarde en } \\
\text { p-waarde }\end{array}$ & \\
\hline Durabillity & $-6,7 \quad 8,3$ & $n=12$ & $\mathrm{~F}=\mathbb{1 1}, 37 / \mathrm{p}=0,00 \mathbb{1}$ & \\
\hline Aessthetic: & $-5,5 \quad 10,0$ & $\mathbf{n}=10$ & $F=5,44 / p=0,022$ & \\
\hline Conformance & $-4,3 \quad 11,1$ & $n=14$ & $\mathrm{~F}=2,97 / \mathrm{p}=0,089$ & \\
\hline Toatures & $-4,3 \quad 11,4$ & $\mathrm{n}=10$ & $\mathrm{~F}=3,18 / \mathrm{p}=0,079$ & \\
\hline Performance & $\begin{array}{lll}-1,7 & 12,3\end{array}$ & $n=46$ & $F=2,63 / p=0,109$ & \\
\hline Reliability & $-1,5 \quad 14,5$ & $\mathrm{n}=9$ & $\mathrm{~F}=0,42 / \mathrm{p}=0,518$ & \\
\hline Perceived Quality & $-0,1 \quad 16,2$ & $n=7$ & $F=0,00 / p=0,982$ & \\
\hline Serviceability & $0,4 \quad 16,6$ & $n=6$ & $\mathrm{~F}=0,02 / \mathrm{p}=0,901$ & \\
\hline
\end{tabular}

In figuur 7.1. worden de RS en RI weergeven bij de PKV'n gebaseerd op produkt, produktie, gebruiker of een mix van deze uitgangspunten. PKV'n gebaseerd op een mix worden beantwoord met relatief snelle, intensieve reacties. Relatief langzame, minder intensieve reacties komen voor bij PKV'n gebaseerd op PKV'n op basis van produktie. Gebruiker-georiënteerde PKV'n leiden tot vrij intensieve, maar ook vrij langzame reacties. Aangezien de meeste PKV'n produktgeoriënteerd zijn, ligt het voor de hand dat zij het gemiddelde beeld in sterke mate bepalen.

Figutur 7.1.: Scort PKV, reactie-smelheid (RS) en reactie-intensiteit (RT)

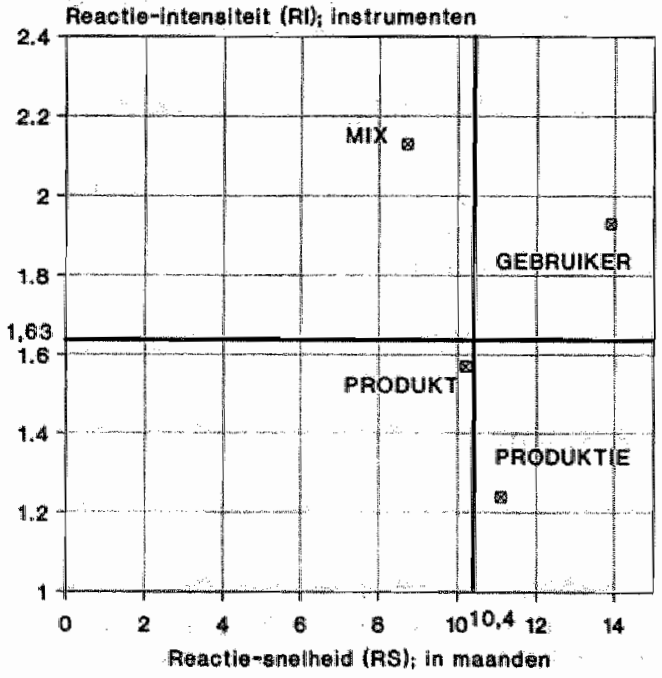

Multiple classificatie-analyse, gebaseerd op de hoofdeffecten van de achtdeling. Telkens is eerst het netto effect en darma de gecorrigeerde RI vermeld die slechts aan de betreffende categorie kan wordlen toegeschreven. De gemiddelde RI lijkt lang ten opzichte van het eerder genoemde gemiddelde van 10,42. Dat gemiddelde is echter gebaseerd op PKV'n, en PKV'n worden in nim $29 \%$ van de gevallen onschreven met twee categorieën. De statistische criteria zijn: $F=2,49$, $p=0,019$ bij 81 wasmemingen. 
De combinatie van de toename in RI en RS, gerelateerd aan de verschillende soorten PKV'n geeft aan hoe er door de belangrijkste concurrent wordt gereageerd ten opzichte van het gemiddelde. Door de conclusies omtrent de hypothesen B8 en B9 samen te vatten blijkt dat op PKV'n die (medie) gebaseerd zijn op "features" met snellere en bovendien intensievere reacties wordt gereageerd dan gemiddeld (zie figuur 7.2, gebied 1). PKV'n gebaseerd op "durability", "aesthetics" of "conformance" worden beantwoord met snellere reacties dan gemiddeld (figuur 7.2., gebied 4). PKV'n gebaseerd op "perceived quality", "reliability", "serviceability" of "performance" worden beantwoord met intensievere, maar minder snelle reacties (figuur 7.2., gebied 2). De gevolgen van PKV" $n$ ten aanzien van de reacties zijn in de vier, in figuur 7.2., aangegeven gebieden dus telkens verschillend.

Figuur 7.2.: PKV'n en toename in RI en RS van de belangrijkste concurrent.

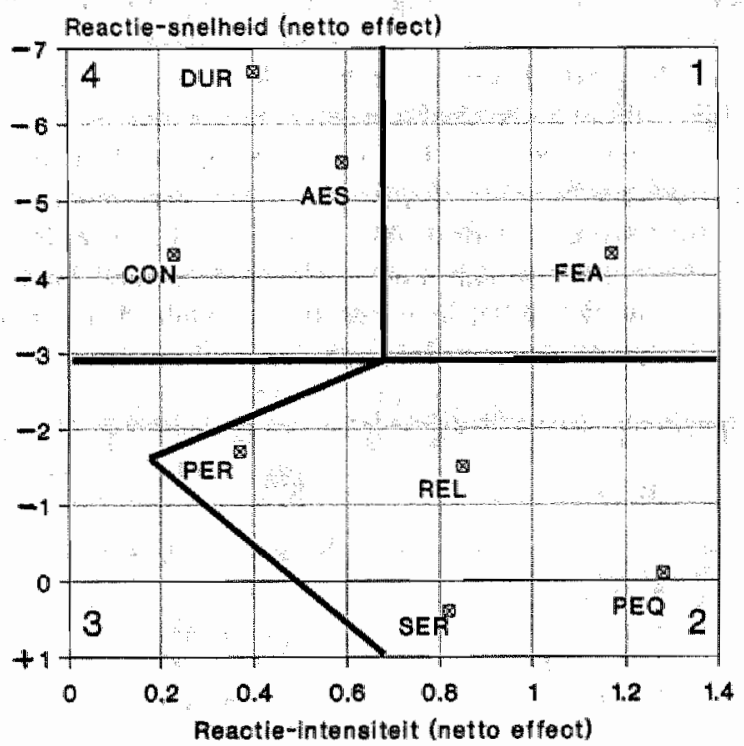

Samenvattend kan het volgende gezegd worden over de soorten PKV, de snelheid van reageren en de intensiteit van de reactie van de belangrijkste concurrenten.

Op de vier oriëntaties voor een PKV blijkt altijd in sterke mate gereageerd te worden door aanpassingen van het produkt zelve door de concurrent.

Daarnaast blijkt dat op een gebruikersgeoriënteerde PKV veel via prijsverlaging en het ontwikkelen van een nieuw produkt gereageerd wordt. Dit zijn veelal intensieve maar niet zo snelle reacties.

PKV'n die op een mix van oriëntaties zijn gebaseerd worden relatief veel beantwoord met promotionele acties, prijsverlagingen en het ontwikkelen van nieuwe produkten. Door deze veelheid van instrumenten zijn dit zeer intensieve reacties, die overigens ook zeer snel geeffectueerd worden.

Op produkt-georiënteerde PKV"n wordt gemiddeld gereageerd; reacties op produktiegeoriënteerde PKV'n zijn het minst intensief. 
Meer gedetailleerd blijkt nog het volgende ten opzichte van het gemiddelde beeld dat ontstaat van acties en reacties op PKV'n. Ten aanzien van de RI en $\mathbb{R S}$ van de belangrijkste concurrent blijkt dat op PKV'n die (mede) gebaseerd zijn op "features" zeer snelle en bovendien zeer intensieve reacties te verwachten zijn. PKV"n gebaseerd op "durability", "aesthetics" of "conformance" worden beantwoord met snelle maar niet zo intensieve reacties: PKV"n gebaseerd op "perceived quality", "reliability", "serviceability" of "performance" worden beantwoord met intensieve reacties, die echter niet zo snel plaatsvinden.

\subsubsection{Invloed van de marktaandeelwinst als gevolg van een PKV en de intensiteit van de concurrentiële reactie}

In deze paragrafif wordt getracht hypothese B10 te toetsen:

"Hoe groter de marktaandeelwinst als gevolg van een PKV, hoe intensiever de reactie van de concurrent".

Het blijkt dat wanneer de marktaandeelwinst beduidend is geweest een hoge RI wordt waargenomen, namelijk 1,89. Dit is slechts weinig hoger dan in het geval dat er geen marktaandeelwinst heeft plaatsgevonden. Een duidelijk lagere RI wordt geconstateerd bij een enigszins hoger marktaandeel. In tegenstelling tot een invers U-verloop van de reactiecurve bij markttoetredingen wordt dus hier het omgekeerde, namelijk een Uverloop geconstateerd. De hypothese kan niet worden ondersteund omdat bij een enigszins hoger marktaandeel een minder intensieve reactie optreedt dan bij een gelijkblijvend marktaandeel. Tabel 7.11. geeft een overzicht van deze uitkomsten.

Tabel 7.11.:

Gepercipieerde marktaandeelverandering van de initiator en RI van de concurrent.

\begin{tabular}{lll}
\hline Marktaandeel: & $R I^{65}:$ & $R I^{66_{*}}$ \\
\hline Enigszins lager: & $2,50(\mathrm{n}=2)$ & \\
Gelijkblijvend: & $1,75(\mathrm{n}=55)$ & $1,76(\mathrm{n}=55)$ \\
Enigszins hoger: & $1,39(\mathrm{n}=94)$ & $1,39(\mathrm{n}=94)$ \\
Beduidend hoger: & $1,89(\mathrm{n}=37)$ & $1,89(\mathrm{n}=37)$ \\
\hline
\end{tabular}

Samenvattend kan worden geconcludeerd dat wanneer de marktaandeelwinst naar aanleiding van een PKV aanzienlijk is geweest, de reactie niet intensiever is geweest dan in het geval van een gelijkblijvend marktaandeel. Is er sprake van een enigszins hoger marktaandeel dan is de RI zelfs lager dan in het geval van een gelijkblijvend marktaandeel. Voor deze constatering zouden veel verklaringen geformuleerd kunnen worden (bijvoorbeeld rond de aard van de PKV en de reactiesnelheid). Immers, gecombineerd met de uitkomsten van 7.2.3. zou verondersteld kunnen worden dat op Statistische criteria: $\mathrm{F}=1,43, \mathrm{p}=0,235$ bij 188 waarnemingen.

Statistische criteria: $F=1,80, p=0,168$ bij 186 waamemingen. De twee waarnemingen met antwoordcategorie "enigszins lager" zijn mu buiten beschouwing gelaten. Paarsgewijze vergelijking van gemiddelden met behulp van Scheffe's toets levert geen statistisch significante verschillen op $(p<0,10)$. 
gebruikers- en mix georiënteerde PKV'n dan wel PKV'n rond "perceived quality", zeer intensief wordt gereageerd en dat zulke PKV"n leiden tot forse stijgingen van het marktaandeel. Dergelijke samenhangen zullen in de volgende paragraaf nader onderzocht worden. Daarbij wordt gekozen voor de verklaring van de reactie-intensiteit, en niet de reactie-snelheid. Het aantal waamemingen van de reactie-snelheid is te laag (81) om gegeven de andere modelvariabelen- in een multivariate analyse te betrekken.

\subsubsection{Multivariate analyse voor de verklaring van de intensiteit van de reactie}

Voordat de multivariate analyse wordt behandeld volgt eerst een kort resume van de tot nog toe gevonden resultaten ten aanzien van de reactie-intensiteit. In vijf hypothesen stond de RI centraal. Deze hypothesen zijn één voor één besproken met als conclusies:

B1: Op PKV"n wordt door de belangrijkste concurrent wel degelijk gereageerd.

B3: In geval van een reactie, vindt dit in de meerderheid van de gevallen plaats met behulp van meer dan één marketing-mix instrument.

B6: De RI is significant lager in de teruggangsfase dan in de andere fasen van de PLC.

B8: Ten aanzien van de RI van de concurrent blijkt dat PKV'n die (mede) gebaseerd zijn op "perceived quality", "features", "reliability", "serviceability" of "performance" worden beantwoord met intensievere reacties. Bovendien blijkt dat PKV'n gebaseerd op meer dan én van de uitgangspunten produkt, produktie of gebruiker beantwoord wordt met een intensievere reactie.

B10: Is er sprake van een enigszins hoger marktaandeel naar aanleiding van PKV'n, dan is de RI lager dan in het geval van een gelijkblijvend marktaandeel of een beduidend hoger marktaandeel.

De conclusies ten aanzien van B1 en B3 zijn zodanig dat in een meerderheid van de gevallen er een reactie van de concurrent plaatsvindt, die in veel gevallen gepaard gaat met de inzet van meer dan één marketing-mix instrument. De conclusies ten aanzien van de overige hypothesen B6, B8 en B10 geven aan hoe de RI verklaard kan worden uit de mogelijke verklarende modelfactoren PLC, soort PKV en marktaandeelwinst. Door echter de hypothesen telkens éen voor én (ceteris paribus) te behandelen is geen rekening gehouden met het multivariate karakter van het model. Door nu tegelijkertijd met alle in het model gespecificeerde variabelen rekening te houden kunnen de genoemde hypothesen opnieuw worden geanalyseerd.

Een meervoudige regressie-analyse is uitgevoerd tussen de reactie-intensiteit (RI) als afhankelijke variabele en als onafhankelijke variabelen de modelvariabelen uit de hypothesen B6, B8 en B10:

1) Fase in de PLC.

2) Soort PKV.

3) Marktaandeelwinst naar aanleiding van PKV.

Door middel van een meervoudig lineair regressiemodel wordt getracht de RI te verklaren uit de verschillende factoren uit het model. Bijlage H.1. geeft telkens de gestandaardiseerde regressiecoëfficiënten en de "adjusted" correlatiecoëfficiënt $\mathbf{R}^{2}$, met de 
In modelspecificatie 1 is gekozen voor de genoemde drie, uit de hypothesen voortvloeiende, factoren als onafhankelijke variabelen. Het blijkt dat de verklaarde variantie $20,4 \%\left(\mathbb{R}^{2 "}\right.$ adjusted $\left.=14,2 \%\right)$ is, en dat de belangrijkste positieve invloed op de RI uitgaat van een PKV yan "features": en "performance", naast de negatieve invloeden van de teruggangsfase van de PLC en van een enigszins hoger marktaandeel als gevolg van de PKV.

Modelspecificatie 2 incorporeert naast de PLC, zoals gesteld in het algemene model, eveneens de andere marktvariabelen. marktaandeel, aantal concurrenten en het gebruik ten anzien van het regelmatig doorvoeren van PKV' $n$ in de branche. Nu neemt de verklaarde variantie toe tot $29,5 \%\left(\mathrm{R}^{2 " 1}\right.$ adjusted $\left.{ }^{\prime \prime}=20,4 \%\right)$. Het blijkt dat, als het in de markt gebruikelijk is om PKV'n door te voeren, de RI sterker is en bovendien als het aantal concurrenten groter is de RI hoger is. Het effect van de teruggangsfase op de RI is sterk negatief. Met andere woorden de RI in de teruggangsfase is significant lager dan in de introductie- en groeifase (die is opgenomen in de constante term). De RI in de verzadigingsfase wijkt echter niet af van de $\mathrm{RI}$ in de introductie- \& groeifase. Verder blijkt de hoogte van het marktaandeel niet significant van invloed te zijn op de RI. De PKV'n gebaseerd op "perceived quality" en "reliability" hebben nu ook een aanzienlijke invloed op de RI, naast de genoemde PKV'n in model 1. De overige conelusies blijven vergelijkbaar met de vorige modelspecificatie.

Vervolgens zijn in modelspecificatie 3 als verklarende variabelen de aanleidingen voor PKV'n toegevoegd aan modelspecificatie 2 (zie voor een overzicht van de belangrijkste resultaten tabel 7.12.). Dit levert een verbetering van de $\mathrm{R}^{2}$ op; de "adjusted" $\mathrm{R}^{2}$ neemt toe van $20,4 \%$ naar $38,1 \%$; de verklaarde variantie van $29,5 \%$ naar $50,2 \%$. Het gevolg van toevoeging van de aanleidingen is dat de meeste soorten PKV'n niet meer statistisch significant $(p<0,10)$ samenhangen met de RI, afgezien van "reliability" en "perceived quality". Deze soorten PKV'n blijven sterk positief samenhangen met de RI. Het blijkt dat de aanleidingen een deel van de verklaring van de RI hebben overgenomen van de soorten PKV'n, hetgeen duidt op een samenhang tussen aanleidingen en soorten PKV. De organisatie-"push" variabelen technische mogelijkheden, organisatieveranderingen en beschikbaarheid van kapitaal hebben naast acties van de concurrentie (zowel PKV"n als andere acties) een positieve invloed op de RI. Met name de relatieve invloed van organisatieveranderingen is groot. Met andere woorden, als organisatieverandering een aanleiding is voor een PKV dan volgt er een intensieve reactie van de concurrent. Hierbij dient wel te worden bedacht dat slechts $13 \%$ van de PKV'n (mede) veroorzaakt wordt door een verandering in de organisatie (zie tabel 6.1., p. 88).

Deze drie modelspecificaties overziende blijkt telkens dat uit de multivariate regressieanalyse naar voren komt dat de reactie-intensiteit negatief correleert met de teruggangsfase in de PLC en het realiseren van cen iets hoger marktaandeel als gevolg van de PKV. De reactie-intensiteit hangt in positieve zin samen met de PKV'n die "reliability" en "perceived quality" betreffen. De RI is ook groter naarmate de onderneming meer concurrenten heeft en het in de branche gebruikelijker is om regelmatig kwaliteitsverbeteringen door te voeren. 
Tabel 7.12: Overzicht van belangrijkste verklarende variabelen van de RI op basis van model specificatie $3^{\mathbb{6}}$.

$\begin{array}{lcc}\text { Invloed } & \begin{array}{c}\text { Positief } \\ \text { (grotere RO) }\end{array} & \text { Negatief } \\ & \text { (kleinere RI): }\end{array}$

Markt

Teruggangsfase in de PLC

Gebruikelijk in branche regel-

matig PKV'n door te voenen $\quad 18$

Aantal concurrenten

Resultait a.g.r. PKV

Netto result taat verbeterd

Enigszins hoger marktaandeel

\section{Soort PKV}

Reliability

Perceived quality

Aanleidingen woor PKV

Technische mogelijkheden $\quad 13$

Verandering van de organisatie $\quad 26$

Beschikbaarheid van kapital . 16

PKV van concurrentie $\quad 13$

Andere actie van de concurrentie $\quad 18$

In termen van aanleidingen voor een PKV blijkt de reactie-intensiteit hoger te zijn naarmate zij meer voortkomen uit organisatie-"push" en concurrentiële overwegingen; de reactie-intensiteit is dus niet hoger in het geval de PKV gebaseerd is op signalen van klanten of gebruikers. Uit de resultaten van de regressie-analyse blijkt een duidelijke samenhang tussen de aanleidingen voor een PKV en de soort PKV. In paragraaf 7.3. zal hier nader op ingegaan worden.

\subsubsection{Conclusies ten aanzien van concurrentiële reacties}

De belangrijkste concurrent reageert wel degelijk op PKV' $n$. Deze reactie heeft in een meerderheid ( $86 \%$ ) van de gevallen te maken met het marketing-mix instrument produkt. Twee van de drie belangrijkste concurrenten die reageren, beantwoorden de PKV weer met cen PKV. De reactie met de marketing-mix instrumenten prijs en promotie is niet onaanzienlijk (respectievelijk 36 en $33 \%$ ). Vervolgens kan nog geconstateerd worden dat, in geval van cen reactie, dit in de meerderheid van de gevallen plaatsvindt met behulp van meer dan ến marketing-mix instrument. De typische reactie van de belangrijkste concurrent is dus een reactie met eveneens een PKV, gecombineerd met eén of meer andere marketing-mix instrumenten. 
Verder kan worden geconcludeerd dat de belangrijkste concurrent in de verzadigingsfase van de PLC op PKV"n reageert met meer "ongrijpbare" reacties. Daarbij is de RI significant lager in de teruggangsfase dan in de andere fasen van de PLC.

Wordt onderscheid gemaakt tussen de verschillende oriêntaties dan blijkt dat op een gebruikersgeoriënteerde PKV veel wia prijsverlaging en het ontwikkelen van een nieuw produkt gereageerd wordt. Dit zijn veelal intensieve maar niet zo snelle reacties. PKV'n die op een mix van oriëntaties zijn gebaseerd worden relatief veel beantwoord met promotionele acties, prijsverlagingen en het ontwikkelen van nieuwe produkten. Door deze veelheid van instrumenten zijn dit zeer intensieve reacties, die overigens ook zeer snel geëffectueerd worden.

Op produkt-georiënteerde PKV'n wordt gemiddeld gereageerd; reacties op produktiegeoriënteerde PKV'n zijn het minst intensief. Verder blijkt dat van PKV'n die (mede) gebaseerd zijn op "features" zeer snelle en bovendien zeer intensieve reacties te verwachten zijn. PKV"n gebaseerd op "durability", "aesthetics" of "conformance" worden beantwoord met snelle maar niet zo intensieve reacties. PKV'n gebaseerd op "perceived quality", "reliability", "serviceability" of "performance" worden beantwoord met intensieve reacties, die echter niet zo snel plaatsvinden. De uitgevoerde regressie-analyse bevestigt intensievere reacties ten aanzien van PKV"n gebaseerd op "reliability" en "perceived quality".

Tot slot blijkt dat wanneer de marktaandeelwinst naar aanleiding van een PKV aanzienlijk is geweest, de reactie niet intensiever is geweest dan in het geval van een gelijkblijvend marktaandeel. Is er sprake van een enigszins hoger marktaandeel dan is de RI zelfs lager dan in het geval van een gelijkblijvend marktaandeel. Dit resultaat wordt bevestigd door de uitgevoerde regressie-analyse. In welke richting het causale verband moet worden gezocht is nog niet duidelijk, omdat het een saldo van twee mogelijke verklaringen betreft. Enerzijds kunnen marktaandeelwinsten leiden tot hogere RI'n, anderzijds kunnen hogere RI'n leiden tot lagere marktaandeelwinsten. In paragraaf 7.4.1. zal hieraan meer aandacht worden gegeven.

Tevens blijkt dat de RI groter is bij een groter aantal concurrenten, en in een branche waar het gebruikelijk is de kwaliteit van het produkt regelmatig te verbeteren en dus een intensieve kwaliteitsconcurrentie heerst. Worden de aanleidingen voor PKV' $n$ in de analyse betrokken dan blijkt dat met name PKV'n gebaseerd op interne organisatie omstandigheden (technische mogelijkheden, organisatie-veranderingen en beschikbaarheid van kapitaal) en concurrentiële acties (zowel PKV'n als andere acties) veel reacties uitlokken (hoge RI'n).

Het blijkt dat, mede op basis de meervoudige lineaire regressie-analyse volgens modelspecificatie 3, dat de RI op een bevredigende wijze is verklaard, maar dat er waarschijnlijk wel verband bestaat tussen de aanleidingen voor PKV'n en de soort PKV" $n$. Om deze relatie te onderzoeken kan niet zonder meer gebruik worden gemaakt van regressie-analyses, vanwege het nominale karakter van de aanleidingen en soorten PKV'n (0/1 variabelen). Derhalve is eerst getracht op een andere wijze, met behulp van correspondentie-analyse, het beeld te completeren. Daarnaast is gebruik gemaakt van paarsgewijze vergelijkingen van de diverse aanleidingen met soorten PKV'n. Aangezien de relatie tussen soorten PKV'n en soorten concurrentiële reacties op een vergelijkbare wijze kan worden onderzocht wordt in de volgende paragraaf enerzijds de relatie tussen aanleidingen en PKV'n gelegd en anderzijds de relatie tussen PKV'n en concurrentiële reacties. 


\subsection{De relatie tussen aanleidingen, PKV'n en soorten reacties nader bekeken}

In deze paragraaf worden aanleidingen, soorten PKV'n en soorten concurrentiële reacties a an elkaar gerelateerd. Eerder is in tabel 7.8. aangegeven welke relaties geconstateerd kunnen worden tussen de soort PKV en de soort concurrentiële reactie. Er werd geconcludeerd dat bij gebruikersgeoriënteerde PKV'n relatief veel reacties met prijsverlagingen en het ontwikkelen van nieuwe produkten naast veranderingen in het produkt zelf voorkwamen. Op mix-georiënteerde PKV'n werd met een veelheid aan instrumenten gereageerd: zowel via het produkt als via promotie, prijs en nieuw produkt.

Tabel 7.13.: Aanleidingen voor de PKV"m en soort PKV (op vrij geaggregeerd nivenu):

\begin{tabular}{lccccc} 
Aanleidingen & Produkt & $\begin{array}{l}\text { Produk- Gebrui- Mix } \\
\text { tie }\end{array}$ & ker & $\mathbf{p}=6$ \\
\hline Markt-"pull" & $76,5 \%$ & $76,6 \%$ & $85,7 \%$ & $92,9 \%$ & 0,120 \\
Organisatie-"push" & $53,9 \%$ & $68,1 \%$ & $64,3 \%$ & $66,7 \%$ & 0,292 \\
Concurrentie & $41,7 \%$ & $34,0 \%$ & $42,9 \%$ & $35,7 \%$ & 0,780 \\
Derden & $19,6 \%$ & $31,9 \%$ & $14,3 \%$ & $23,8 \%$ & 0,335 \\
Aantal PKV'n $\left(205^{\circ}\right)$ & 102 & 47 & 14 & 42 & \\
\hline
\end{tabular}

Figur 7.3.2 Aanleidingen voor en reacties op verschillende soorten PKV"n.

Soorten PKV'n en aanleidingein

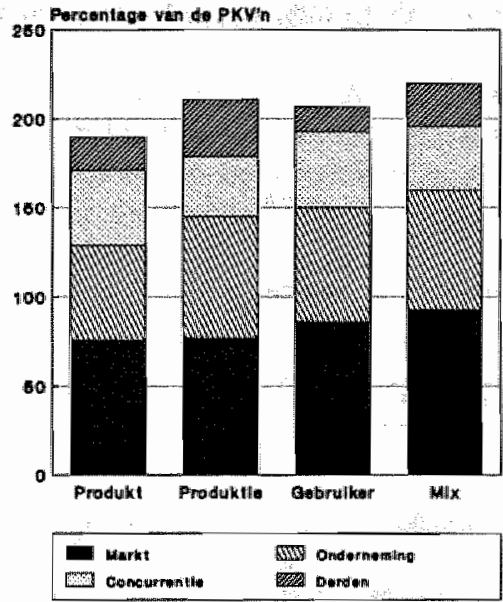

Soorten PKV'n en reacties

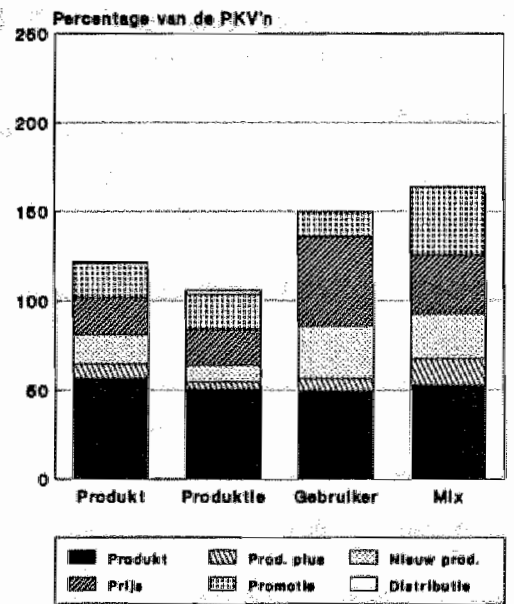

Gebaseerd op $x^{3}$-toets.

De vraag naar aanleidingen werd door 205 van de 206 ondememingen beantwoord. 
Net als in tabel 7.8. bij het verband tussen de oriëntaties van de PKV en de reactieinstrumenten, zal het verband tussen de aanleidingen voor een PKV en de oriëntaties van de PKV'n allereerst op een vrij geaggregeerd niveau onderzocht worden. Ten aanzien van de specifieke aanleidingen voor de versehillende soorten PKV'n valt het op dat nauwelijks verschil is in genoemde aanleidingen voor de verschillende oriëntaties van de PKV'n. Bij PKV"n gebaseerd op een mix van oriëntaties en op de gebruiker worden iets meer aanleidingen genoemd en in het bijzonder aanleidingen op basis van marktsignalen. Tabel 7.13. bevat deze resultaten. Figuir 7.3. geeft nog eens de aanleidingen en reacties op een andere wijze weer.

Het is nu eveneens interessant na te gaan of en zo ja welke relatie tussen de verschillende aanleidingen op basis van de onderliggende items en de soorten PKV'n op basis van de achtdeling is te leggen. Vervolgens is het dan mogelijk om de relatie te leggen tussen deze soorten PKV'n en de instrumenten van de concurrentiële reactie. Als analyseinstrument is gekozen voor een eenvoudige benadering waarbij enerzijds telkens paarsgewijs de aanleidingen en PKV'n (zie tabel 7.14) en anderzijds PKV'n en reacties (zie tabel 7.15) zijn geanalyseerd. Het nadeel van een dergelijke benadering is dat het een partiele analyse is omdat geen rekening wordt gehouden met eventuele simultane interacties tussen en binnen de aanleidingen, PKV'n en reacties. Er zijn twee redenen om toch de partiële analyse te bespreken. Ten eerste komen de variabelen met een gering aantal waarnemingen niet voor omdat niet voldaan wordt aan de minimum criteria voor opname in de tabel 7.14 resp. 7.15 . De tweede reden is dat het resultaat van de partiele analyses niet substantieel afwijkt van de oplossing verkregen met behulp van correspondentie-analyse (Benzécri 1969, Lebart, Morineau \& Warwick 1984). De toepassing van deze techniek levert echter zowel voor de relatie aanleidingen/soorten PKV als soorten PKV/reacties geen statistisch bevredigende resultaten op ${ }^{70}$. Schematisch is onze analyse als volgt weer te geven:

Schema 7.1: $\quad$ Schematische weergave van de analyses.

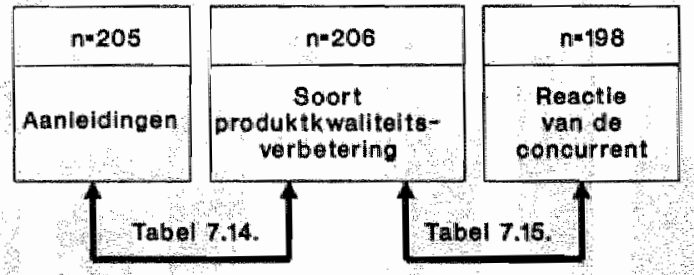

Doot middel van een correspondentio-analyse (met behulp van het DUALCF algoritme; Nishisato \& Nishisuto 1984) is eerst de relatio tussen de aanleidingen en soorten PKV onderzocht op basis van 11 van de 12 aanleidingen (met de meeste wamemingen; Hoffman \& Franke 1986). Dat tresulteerde in tweedimensionale oplossing (twee dimensies statistisch significant met $p<0,05$ ) met verklaring van $71 \%$. De oplossing bleek echter instabiel te zijn, met name door het toch nog geringe aantal waamemingen in een aantal categorieën en de lage correlatie-ratio (een maat voor de verklaring wan de soorten PKV"n door de aanleidingen en omgekeerd voor de twee dimensies).

Vervolgens is de relatie tussen soorten PKV'n en de reacties onderzocht (met 11 van de 16 reacties). Dat resulteerde eveneens in een tweedimensiomale oplossing (twee dimensies statistisch significant met $p<0,05$ ) met een verklaring van $66 \%$. De oplossing bleek om dezelfde reden als genoemd bij de aanleidingen instabiel te zijm. 
Het blijkt dat als een PKV bij de concurrentie de aanleiding vormt voor de eigen PKV, dit leidt tot een PKV die zich sterk richt op de "performance" van het produkt. Klantenwensen leiden niet zo zeer tot verbeteringen van deze primaire kenmerken van het produkt, maar wel tot PKV'n gericht op de service-vriendelijkheid en de overeenstemming met de specificaties. PKV'n gebaseerd op gebruikerswensen komen minder vaak voor bij verbeteringen in de overeenstemming met de specificaties; zij hangen sterk samen met verbeteringen in de secundaire eigenschappen ("toeters en bellen") van het produkt. Organisatie-"push" aanleidingen, met name veranderingen in de organisatie en in de beschikbaarheid van kapitaal leiden tot PKV'n gericht op de "perceived quality". Andere technische mogelijkheden zorgen vooral voor PKV'n die de betrouwbaarheid van het produkt vergroten. Als de beschikbaarheid van kapitaal de aanleiding voor een PKV is, leidt dit relatief weinig tot een verbetering van de "performance".

$\mathrm{Na}$ in tabel 7.14. het verband tussen aanleidingen voor een PKV en de soort PKV gedetailleerder te hebben aangegeven, zal in tabel 7.15. gedetailleerder ingegaan worden op de relatie tussen de soort PKV en de reactie van de belangrijkste concurrent.

De relatieve reacties verschillen eveneens tussen de soorten PKV'n. "Performance"verbeteringen leiden relatief vaker tot reacties met het instrument produkt, en met name met prestaties van het produkt. Verbeteringen ten aanzien van "features" leiden relatief vaker tot reacties met nieuwe produkten, maar ook met promotie/reclame. "Reliability"verbeteringen leiden relatief vaak tot reacties die een verbetering van de prestaties inhouden, het ontwikkelen van nieuwe produkten en (tijdelijke) verkoopacties. Verbeteringen ten aanzien van "conformance" leiden tot minder intensieve reacties. Met name wordt er relatief minder vaak gereageerd met nieuw produkt ontwikkelingen. Op "serviceability"-verbeteringen wordt relatief vaak gereageerd met verbeteringen ten aanzien van aspecten rond het produkt, zoals service.

Op verbeteringen ten aanzien van "aesthetics" wordt relatief vaak gereageerd met promotie om het imago te verbeteren, en minder met PKV' $n$ en verbeteringen ten aanzien van de prestaties van het produkt. Tot slot leiden PKV'n op basis van "perceived quality" relatief vaak tot reacties met het verlagen van de prijzen en het ontwikkelen van een nieuw produkt. 

de aangegeven atrileiding per soort PKV'.

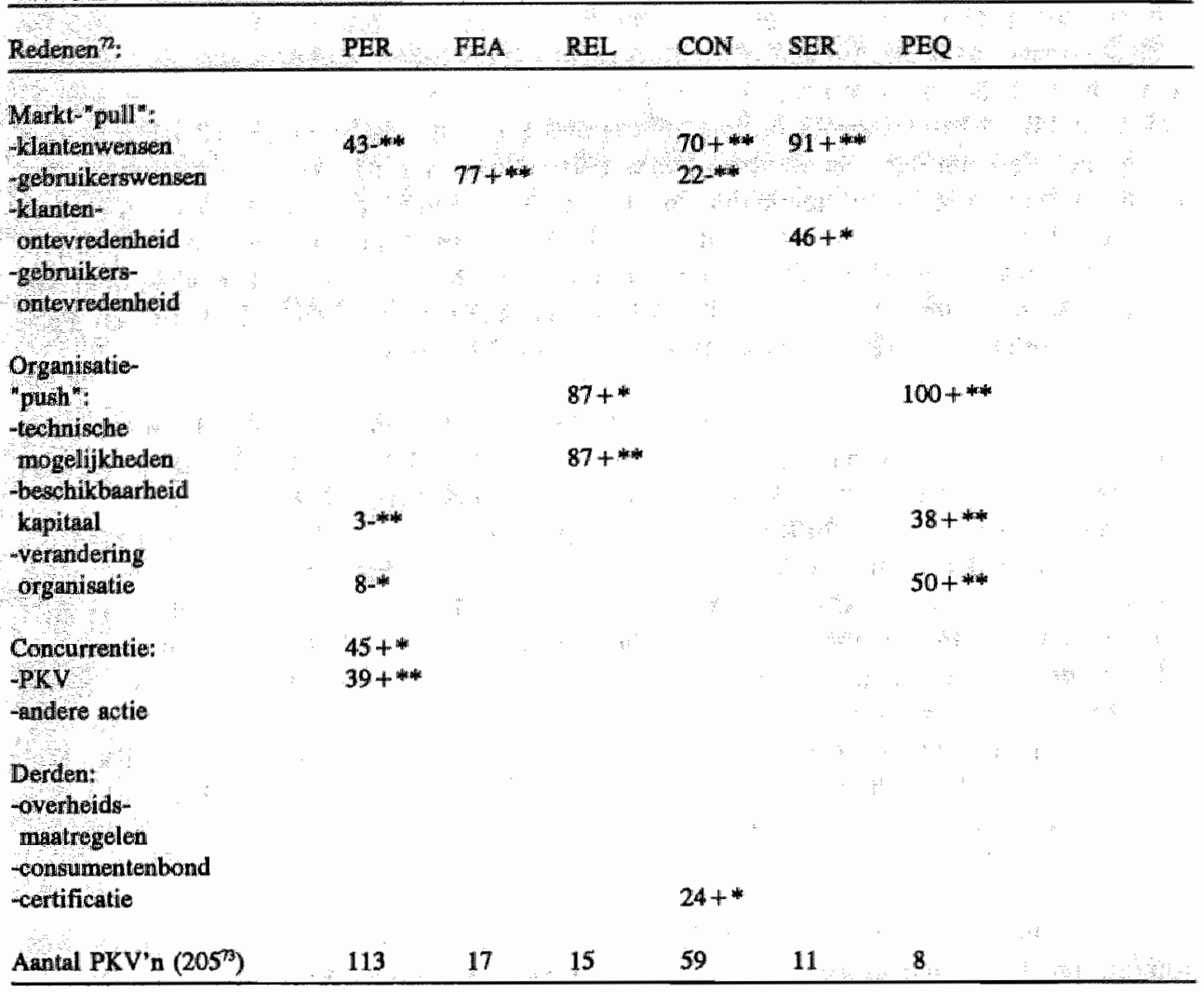

7 De statistisch significante $(\mathrm{p}<0,10)$ verschillen tussen aanleidingen voor de PKV"n met wel en niet de betreffende soort PKV. De randvoorwaarden voor opmame van het betreffende percentage

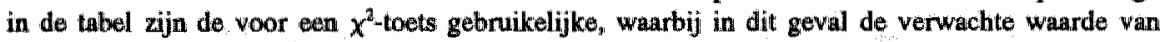
maximall cén cel $(=25 \%)$ kleiner mag zijn dan vijf. De significantieniveaus bebben betrekking op $x^{2}$-toets met de (conservatieve) Yates correctie. Naast het percentage is door middel van een $(+)$ angeven dat, in het geval een. PKV van de betreffende soort, de aanleiding vaker voorkomt dan in het gewal die soort PKV niet wan toepassing is. Het omgekeerde wordt aangegeven met een (-). Significantieniveaus worden aangegeven door $*=p<0,10$ en $* *=p<0,05$.

Gebruikte afkortingen: performance (PER), features (FEA), reliability (REL), conformance (CON), durability (DUR), serviceability (SER), aesthetics (AES) en perceived quality (PEQ). Bij durability en aesthetics werd geen enkele significant afwijkende aanleiding gevonden, gegeven de voorwarden genoemd in de worige noot. 


\begin{tabular}{|c|c|c|c|c|c|c|c|}
\hline Soort PKV75: & PER & FEA & REL & CON & SER & AES & PEQ \\
\hline+2 & $\ldots$ & & $\therefore$ & & $\therefore$ & & \\
\hline $\begin{array}{l}\text {-Produlkt: } \\
\text { PKV } \\
\text { prestaties produlukt } \\
\text { wormgeving }\end{array}$ & $24+*$ & & $40+*$ & & & $0-*$ & \\
\hline $\begin{array}{l}\text {-Produkt plus: } \\
\text { garantievoorwaarden } \\
\text { service bij aflevering } \\
\text { after-sales service } \\
\text { verkoopvoorwaarden }\end{array}$ & & & & & $27+*$ & & \\
\hline $\begin{array}{l}\text {-Nieuw produkt: } \\
\text { nieuw produkt } \\
\text { assortiment }\end{array}$ & & $\begin{array}{l}41+* * \\
41+* *\end{array}$ & $33+*$ & $\begin{array}{l}7-* * * \\
4-* * *\end{array}$ & & & $50+* *$ \\
\hline $\begin{array}{l}\text {-Promotie: } \\
\text { promotie/reclame } \\
\text { verkoopacties } \\
\text { imago d.m.v. reclame } \\
\text { merknaam }\end{array}$ & & $24+* *$ & $27+*$ & & & $35+* *$ & \\
\hline $\begin{array}{l}\text {-Prijs: } \\
\text { prijsverlaging } \\
\text { prijsverhoging }\end{array}$ & & & & & & & $\begin{array}{l}75+* * \\
75+* *\end{array}$ \\
\hline $\begin{array}{l}\text {-Distributie: } \\
\text { distributie }\end{array}$ & & " & & & & & \\
\hline Aantal PKV'n $\left(198^{6}\right)$ & 109 & 17 & 15 & 56 & 11 & 17 & 8 \\
\hline
\end{tabular}

Samengevat blijkt het volgende:

Wanneer de indeling voor de vier oriëntaties voor een PKV en de vier soorten aanleidingen voor een PKV gehanteerd worden, blijkt dat er geen significante verschillen zijn tussen deze vier oriêntaties en de vier aanleidingen. Op dit geaggregeerde niveau zijn geen verschillen te constateren. Wanneer deze vier oriẻntaties voor een PKV gerelateerd worden aan de meer gedetailleerde reacties op een PKV blijkt dat in ruim de heift van de gevallen altijd met verbeteringen in het produkt wordt geantwoord door de belangrijkste concurrent. Daarnaast wordt bij een gebruikers-georiënteerde PKV relatief veel

De statistisch significante $(\mathrm{p}<0,10)$ verschillien tussen reacties op PKV'n met wel en niet de betreffende soon PKV. Zie verder noot 71 .

Bij durability werd geen enkele significant afwijkende reactie gewonden, gegeven de voorwaarden genoemd in de vorige noot. Zie voor afkortingen noot 72.

198 van de 206 ondernemingen beantwoordden deze vraag. 
gereageerd met prijsverlagingen en het ontwikkelen van nieuwe produkten. Op een mixoriëntatie van een PKV wordt daarnaast veel gereageerd met verhogen van de promotie, verlagen van đe prijs en het ontwikkelen van nieuwe produkten.

Wanneer een meer gedetailleerde indeling wan de 206 PKV'n wordt gehanteerd, wordt meer inzicht verschaft in de specifieke samenhang tussen (12) aanleidingen voor een PKV bij industriêtle ondernemingen, de (8) soorten PKV en de (16) reacties op een PKV door de belangrijkste concurrent. De resultaten van onze analyses zijn samengevat in tabel 7.16. Ten opzichte van het al eerder (zie paragraaf 7.1. en 7.2.) geschetste algemene beeld, kunnen nu de volgende specifieke conclusies getrokken worden:

* Een PKV gericht op de primaire kenmerken van het produkt ("performance") wordt relatief vaak veroorzaakt door een PKV bij de concurrentie en weinig geïnitieerd door wensen van klanten, beschikbaarheid van kapitaal of veranderingen in de organisatie; concurrenten reageren -op hun beurt- hier weer op door de prestaties van het produkt te verbeteren.

* Een PKV gericht op de secundaire eigenschappen van het produkt ("features") komt vaak voort uit gebruikerswensen; concurrenten beantwoorden zo'n PKV vrij vaak met het ontwikkelen van een nieuw produkt en vergroten van de promotie/reclame inspar. uing.

* Een PKV gericht op het vergroten van de duurzaamheid wordt niet gekenmerkt door specifieke aanleidingen noch door specifieke reacties van concurrenten.

* Een PKV gericht op het verbeteren van de betrouwbaarheid wordt relatief vaak veroorzaakt door technische mogelijkheden daartoe binnen de organisatie zelf en wordt vaak beantwoord met het verbeteren van de prestaties van concurrerende produkten, nieuwe produkten of verkoopacties door de belangrijkste concurrenten.

* Een PKV die (een grote mate van) overeenstemming met de specificaties ten doel heeft, wordt vaak veroorzaakt door klantenwensen en certificatie-eisen en minder door gebruikerswensen. Zo'n PKV wordt relatief weinig beantwoord door nieuwe produkten te ontwikkelen.

* Een PKV die de service-vriendelijkheid van een PKV vergroot komt in relatief sterke mate voort uit klantenwensen en -ontevredenheid; reacties van concurrenten betreffen vooral de produkt-plus (waaronder ook de service- en garantievoorwaarden vallen).

* Een PKV gericht op het verbeteren van de afwerking en schoonheid ("aesthetics") wordt niet door heel specifieke zaken veroorzaakt; de concurrenten reageren op zo'n PKV vaak door hun imago te verbeteren via promotie en relatief weinig door de prestaties van het produkt te verbeteren.

* Een PKV die tot doel heeft het verbeteren van de reputatie en de ongrijpbare produktkenmerken ("perceived quality") komt relatief vaak voort uit veranderingen in de organisatie en de beschikbaarheid van kapitaal in de eigen organisatie; de belangrijkste concurrenten reageren relatief vaak met prijsverlagingen en het ontwikkelen van nieuwe produkten in de industriële markt.

Hoewel de aanleidingen, PKV'n en reacties in tabel 7.16. nog gerubriceerd zijn naar de drie oriëntaties voor PKV'n blijkt niet dat -op grond van de meer gedetailleerde informatie die nu gepresenteerd wordt- nu wel duidelijk patronen van actie en reactie per 
"PKV-oriẽntatie" zijn vast te stellen.

Wel blijkt dat een "performance" - PKV door een PKV yan de concurrent geînitieerd wordt en vervolgens weer als zo"n PKV yoor de concurrent beschouwd kan worden. Aangezien maar liefst 114 van de 206 onderzochte PKV'n in deze categorie vallen, kan geconcludeerd worden dat duidelijke indicaties bestaan dat er een actie-reactie patroon van PKV"n bestaat met betrekking tot de primaire kenmerken van een produkt waarbij men steeds tracht de prestaties van het produkt te verbeteren.

Tabel 7.16.: Aanleidingen, PKV'n en reacties.

$\begin{array}{lll}\text { Aanleidingen } & \text { Produktkwaliteits- } & \text { Resoties wan de belangrijksto } \\ & \text { verbeteringen } & \text { concurrenten }\end{array}$

\section{PRODUKTORIENTATIE}

+PKV van de concurrent

Performance

+ Prestaties produkt

-Klantenwensen

-Beschikbaarbeid kapitalal

-Verandering organisatie

+ Gebruikerswensen

Features

+ Nieuw produkt

+Promotie/reclame

Durability

PRODUKTIE-ORIENTATIE

+ Technische mogelijkheden

Reliability

+ Prestaties produkt

+ Nieuw produkt

+ Verkoopacties

+ Klantenwensen

Conformance

-Nieuw produkt

+ Certificatie-eisen

-Gebruikerswensen

\section{GEBRUIKERSORIENTATIE}

+ Klantenwensen

+ Klanten-ontevredenheid

Serviceability +Produkt plus (service etc.)

Aesthetic:

+Promotie i.w.m. imago

-Prestaties produkt

+ Verandering organisatie

+ Beschikbaarheid kapitaal

Perceived Quality *Prijsverlaging

+ Nieuw produkt

Tevens blijkt dat een PKV die de service-vriendelijkheid van een produkt vergroot, beantwoord wordt door de concurrenten met het verbeteren van hun service. Op dit terrein komt klaarblijkelijk imitatie van de initiatiefnemer vrij vaak voor. Cruciaal lijkt hierbij het onderkennen van de klantenwensen en -ontevredenheid door de initiatiefnemer 
tot de PKV.

Organisatie-"push" elementen geven vooral aanleiding tot het verbeteren van de gepercipieerde kwaliteit. Op het verbeteren van deze subjectieve kwaliteitsverbetering word vooral met prijsverlagingen en nieuwe produkten gereageerd door de concurrenten en ogenschijnlijk niet met promotie-instrumenten. Die worden vaak ingezet als reactie op het verbeteren van de secundaire produktkenmerken en de "aesthetics".

\subsection{Het gepercipieerde resultaat van de PKV'n}

In deze paragraaf wordt in 7.4.2. het gepercipieerde resultaat (in termen van netto resultaat marktaandeel) gerelateerd aan de modelwariabelen uit de externe omgeving, aanleidingen, soort PKV en de RI. Daaraan voorafgaand worden eerst in paragraaf 7.4.1. hypothesen $\mathrm{C} 1$ tot en met $\mathrm{C} 4$ bivariaat getoetst. Tot besluit bevat 7.4.3. de conclusies.

\subsubsection{Verbetering van marktaandeel en netto resultaat als gevolg van PKV'n} Hypothese C1 luidt:

"PKV'n gebaseerd op motieven die uitgaan van zowel klantenwensen als technische mogelijkhieden zijn. succesvoller ten aanzien van resultaat en marktaandeelgroei dan PKV'n die niet gebaseerd zijn op zowel klantenwensen als technische mogelijkheden".

Door de marktaandeelwinst en de verbetering van het netto resultaat als gevolg van een PKV te relateren aan het wel of niet baseren van de PKV op zowel marktaspecten als technische aspecten ontstaat tabel 7.17.. Het blijkt dat in het geval ondernemingen zich bij een PKV baseren op zowel marktaspecten als technische aspecten, de marktaandeel-winst groter is en bovendien vaker een verbetering van het netto resultaat wordt gerapporteerd dan wanneer ondernemingen een PKV niet op deze aspecten baseren. Ten aanzien van hypothese $\mathrm{Cl}$ is er dus wel een aanwijzing dat PKV'n gebaseerd op zowell de markt als de technische kennis succesvoller zijn dan PKV"n die niet op beide factoren zijn gebaseerd. Echter de hypothese is op statistische criteria niet verdedigbaar.

Hypothese $\mathrm{C} 2$ luidt:

"De soort PKV is van invloed op het gepercipieerde resultaat (marktaandeel en/of netto resultaat)".

Eerst wordt de invloed op het marktaandeel behandeld. Wanneer nu de marktaandeelverhoging wordt uitgedrukt in een tweedeling verhoging/geen verhoging, ontstaat tabel 7.18.. De verschillen in succes tussen de soorten PKV'n zijn minimaal. Het grootste succes treedt op wanneer een PKV is gebaseerd op de gebruiker of een mix. Relatief weinig marktaandeelverhogingen treden op wanneer de PKV is gebaseerd op produktie.

Relatief weinig verbeteringen in netto resultaat treden op wanneer sprake is van PKV' $n$ gebaseerd op produkt. De verschillen zijn echter niet aantoonbaar significant. De hypothese wordt dus niet bevestigd. 
Tabel 7.17.: Relatie tuissen PKV'n gebaseerd op zowel marktmotieven als technischie motiewen en gepercipieerde marktaandelwinst en verbetering van netto resultaat.

Aanleidingen: Marktmotieven \& technische mogelijkheden"

Overige anuleidingen

Marktaandeel ${ }^{\text {Th: }}$ :

Lager:

$1(1,2 \%)$

$19(23,5 \%)$

$1(0,9 \%)$

Gelijkblijvend:

$43(53,1 \%)$

$39(33,9 \%)$

Exigszins hoger:

$18(22,2 \%)$

$-$

$56(48,7 \%)$

Beduidend hoger:

$81(100 \%)$

$19(16,5 \%)$

Totalal $(\mathrm{m}=196)$ :

$115(100 \%)$

Netto Resultagt":

Verbetering:

$49(61,2 \%)$

$59(52,7 \%)$

Geen verbetering

$31(38,8 \%)$

$53(47,3 \%)$

Totaal $(n=192)$ :

$80(100 \%)$

$112(100 \%)$

Tabel 7.18.: Soorten PKV en het gepercipieerde resultaat.

\begin{tabular}{llc} 
Scort PKV & Verhoging marktaandeel $^{\$ 0}$ & Verbetering n \\
\hline Produkt & $70(69,3 \%)$ & $49(50,0 \%)$ \\
Produktie & $26(59,1 \%)$ & $27(61,4 \%)$ \\
Gebruiker & $11(78,6 \%)$ & $9(64,3 \%)$ \\
Mix & $29(78,4 \%)$ & $23(63,9 \%)$ \\
Totaal: & $-136(69,4 \%)$ & $108(56,3 \%)$
\end{tabular}

Hypothese C3 luidt:

"De snelheid waarmee de concurrentie reageert heeft een negatief effect op het gepercipieerde resultaat (netto resultaat en/of marktaandeel)"

Eerst wordt het effect op het marktaandeel behandeld. Het blijkt dat er een positief verband bestaat tussen de tijd die de concurrent nodig had voor de reactie op de betreffende PKV en de verhoging van het marktaandeel naar aanleiding van de PKV. In geval van een gelijkblijvend marktaandeel blijkt de gemiddelde RS 8,8 maanden te zijn.

Alle ondernemingen die minsteris eén van de vier aanleidingen onder markt-"pull", en de aanleiding technische moggelijkheden hebben aangegeven.

Statistische criteria: $x^{2}=2,82, p=0,421$.

Statistische criteria: $\chi^{2}=1,07, p=0,302$.

Statistische criteria: $x^{2}=4,16, p=0,245$ bij 196 warrmemingen.

Statistische criteria: $\chi^{2}=3,24, p=0,355$ bij 192 waamemingen. 
In geval van enige groei of een beduidende groei van het marktaandeel is de RS hoger, respectievelijk 9,9 en 15,5 maanden. Op een andere wijze gepresenteerd betekent dit da bij reactie-snelheden van maximaal 6 maanden het percentage ondernemingen dat een marktaandeelverbetering percipieert $59 \%$ is, terwijl bij reacties van meer dan één jaar di percentage $84 \%$ bedraagt. De hypothese wordt dus niet verworpen (bij $p<0,05$ ) met betrekking tot het marktaandeel. Snelle reacties gaan blijkbaar ten koste van de groei var het eilgen marktaandeel. Ten aanzien van het netto resultaat kan de hypothese niet worden ondersteund. $\mathrm{Er}$ is geen significant verschil in reactie-snelheden gegeven de gepercipieerde netto resultaten. Tabel 7.19. bevat de resultaten.

Tabel 7.19:: Reactiesnelheden (RS) van de concurrent bij verschillende marktaandeel resultaten ex netto resultaten.

\begin{tabular}{|c|c|c|c|c|c|}
\hline Reactie-snelheid & $<6$ mind & $\begin{array}{l}6-12 \\
\text { mind }\end{array}$ & $>12$ mnd & $\begin{array}{l}\text { Gemiddelde RS } \\
\text { (standaarddeviatie) }\end{array}$ & $\begin{array}{l}\text { Aantal } \\
\text { wasmemingen }\end{array}$ \\
\hline
\end{tabular}

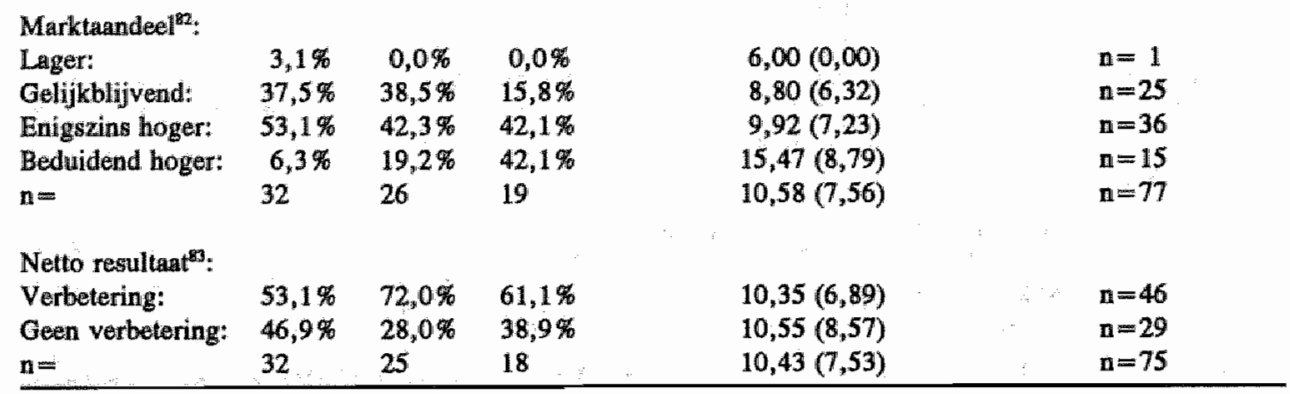

Tot slot wordt hypothese $\mathrm{C} 4$ behandeld. Deze luidt:

"Naarmate de intensiteit van de concurrentiële reactie toeneemt, is het negatieve effect of het gepercipieerde resultaat (marktaandeel en/of netto resultaat) groter".

Eerst wordt het effect op het marktaandeel behandeld. Naarmate de RI hoger is zou di marktaandeelwinst naar aanleiding van een PKV lager moeten zijn. Dit gaat wel op voo: de categorieën "lager", "gelijkblijvend" en "enigszins hoger", waar de RI'ı respectievelijk 2,50, 1,76 en 1,39 zijn. Echter, de RI is weer hoger bij een "beduiden hogere" marktaandeelwinst, namelijk $1,89^{84}$. De hypothese betreffende het marktaandee wordt derhalve niet ondersteund. Op een andere wijze gepresenteerd blijkt dat bij he uítblijven van de reactie van de concurrent ruim $73 \%$ van de ondernemingen eer verbetering van het marktaandeel percipieert. In het geval dat de reactie van $d x$ concurrent met meer dan én instrument heeft plaatsgevonden slechts $63 \%$ van $d t$

Statistische criteria: $\mathrm{F}=2,98, \mathrm{p}=0,037$ bij 77 warnemingen. Wanneer de categorie "lager" buites beschouwing wordt gelaten: $F=4,27, p=0,018$ bij 76 wraarnemingen. Tussen de categori "beduidend hoger" en respectievelijk "enigszins hoger" en "gellikblijvend" bestaan statistiscl significante verschillen (op basis van Scheffé"s toets met $p<0,10$ ), 
ondernemingen een verbetering van het marktaandeel waarneemt.

Het probleem is nu welke verklaring moet worden gegeven voor dit verschijnsel. Daarvoor wordt de conclusie van de met hypothese $C 4$ vergelijkbare hypothese BlO gebruikt. De conclusie van B10 luidde, dat wanneer de marktaandeelwinst naar aanleiding van een PKV aanzienlijk is geweest, de reactie niet intensiever is dan in het geval van een gelijkblijvend marktaandeel. Is er sprake van een enigszins hoger marktaandeel dan is de RI zelfs lager dan in het geval van een gelijkblijvend marktaandeel. Er wordt bij deze formulering van de hypothese dus verondersteld dat de marktaandeelwinst van de PKV bij de concurrentie bekend, of in ieder geval voorspelbaar; is voordat wordt gereageerd.

Enerzijds kan, $\mathrm{C} 4$ volgend, een minder intensievere reactie van de concurrent leiden tot een hogere marktaandeelwinst. Anderzijds kan, juist vanwege de grote marktaandeelwinst, de reactie extra intensief zijn.

De marktaandeelwinst kan dus zowel oorzaak als gevolg zijn van de RI. Het saldo van deze twee tegengestelde causale verbanden komt nu in onze RI-cijfers tot uitdrukking, en is voor "beduidend hogere marktaandelen" positief, zodat de reactie-intensiteit hoger is. Er kan derhalve aan de hand van dit onderzoek geen definitieve uitspraak gedaan worden over hypothese C4. Wel is duidelijk dat er twee tegengestelde effecten werkzaam zijn, en dat verdere verklaring van het saldo van deze effecten ten aanzien van de marktaandeelwinst gezocht moet worden in een multivariate analyse, waarbij naast de RI, bijvoorbeeld de in de andere hypothesen genoemde RS, aanleidingen en soorten PKV'n kunnen worden opgenomen als verklarende variabelen ${ }^{35}$.

Tabel 7.20,: $\quad$ Reactie-intensiteit $(\mathbb{R I})$ van de concurrent bij verschillende marktaandeel resultaten en netto resultaten.

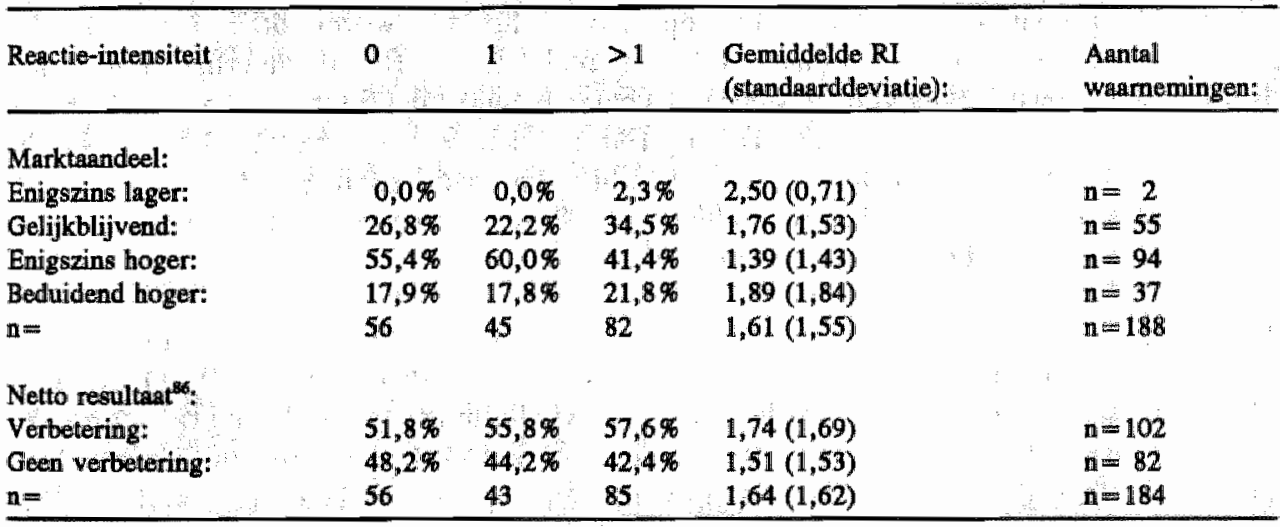

Eerder (in tabel 7.12.) bleek bijwoorbeeld al dat op PKV'n die (mede) gebaseerd zijin op acties (kwaliteitverbeteringen of andere acties) van concurrenten met een hogere RI wordt gereageerd. Het blijkt dat thet U-vormige verloop bij deze "volgers" hetzelfde is als voor de in tabel 7,20. genoemdle totale groep ondememingen. Voor PKV'n die niet zijn gebaseerd op acties vain concurrenten blijkt dat de RI bij een gelijkblijvend marktaandeel of enigszins hoger marktaandeel ongeveer gelijk is $(1,20)$, terwijl bij een beduidend hoger marktaandeel de RI ook beduidend hoger ligt $(i, 61)$. 
Ten aanzien van de verbetering van het netto resultaat blijkt dat de RI enigszins hoger is bij PKV'n waarbij een verbetering van het netto resultaat heeft plaatsgevonden. Het verschil is echter niet statistisch significant, zodlat de hypothese ten aanzien van de verbetering van het netto resultaat niet kan worden ondersteund. In tabell 7.20. staan de ressultaten en in de volgende paragraaf wordt de multivariate analyse behandeld.

\subsubsection{Multivariate analyse yoor de verklaring van de marktaandeelwinst en het netto resultaat}

Door middel van een multivariate analyse (discriminantanalyse) is getracht het resultaat van de PKV te verklaren. In bijlage H.2. wordt het gebruik van discriminant-analyse besproken en worden de uitkomsten gepresenteerd van vier specificaties van het model. In deze paragraaf wordt ingegaan op de resultaten van de uiteindelijk, in bijlage $\mathrm{H}_{\text {, gekozen }}$ modellen.

Het succes van PKV' $n$ in termen van marktaandeelwinst wordt in model 4 door vier factoren bepaald (canonische correlatiecoëfficiënt 0,45 ): de externe marktomstandigheden, de aanleidingen voor het doorvoeren van een PKV, de soort PKV en de reactie-intensiteit. PKV' $n$ in de verzadigings- of teruggangsfase leiden tot een kleinere kans op een hoger marktaandeel. Is het in de branche gebruikelijk om regelmatig PKV'n door te voeren dan heeft een PKV een negatief effect op de marktaandeelwinst. Is het aantal concurrenten groter dan neemt de kans op marktaandeelwinst toe. PKV'n doorgevoerd naar aanleiding van omstandigheden of sterke punten binnen de organisatie verhogen eveneens de kans op een hoger marktaandeel. PKV'n naar aanleiding van signalen uit de markt (klanten, gebruikers en concurrentiële acties) hebben een minder grote kans om tot een hoger marktaandeel te komen. Dat PKV'n die zowel gebaseerd zijn op markt- als op organisatie-aspecten een grotere kans op succes hebben wordt door éćn van de modelspecificaties (model 2 in bijlage H.2.) wel ondersteund. Het afzonderlijke effect van de organisatie-"push" aanleidingen alleen is echter beduidend groter dan van de "marktaanleidingen" (model 3 in bijlage H.2.). Ten aanzien van de soorten PKV'n wordt geconstateerd dat PKV'n op basis van "reliability" en "serviceability" de kans verhogen op een hoger marktaandeel. Tot slot blijken intensieve reacties van concurrenten tot een kleinere kans op een hoger marktaandeel te leiden.

Het succes in termen van netto resultaat kan woornamelijk worden verklaard uit de soort PKV en de aanleiding voor de PKV (canonische correlatiecoëfficiënt 0,41 ). PKV'n gebaseerd op "conformance", "durability" en "serviceability" zijn belangrijk voor de vergroting van het netto resultaat. Wanneer de nadruk van de PKV ligt op één of meer van die soorten PKV, dan is er een grotere kans op een verbetering van het netto resultaat. Wanneer de PKV is doorgevoerd naar aanleiding van signalen van derden (certificatie-eisen, overheid) dan is de kans op een positief resultaat eveneens groter. De RI van de concurrent, hoewel positief gecorreleerd met de kans op verbetering van het netto resultaat, speelt nauwelijks een rol, evenals de fase in de PLC. Tabel 7.21. vat de belangrijkste conclusies samen aan de hand van de gestandaardiseerde coëfficiënten van de discriminantfunctie en het relatieve discriminatievermogen van de variabelen, uitgedrukt in procenten. 
Tabel 7.21.: Overzicht van belangrijkste verklarende wariabelen ten aamzien van het succes in termen vam werbetering marktaandeel en verbetering van het netto resultaat (gestandaardiscende coefficiēnten wan de discriminantfunctie *100 (COEF), respectievelijk het relatief discriminatievermogen in procenten (DIS))

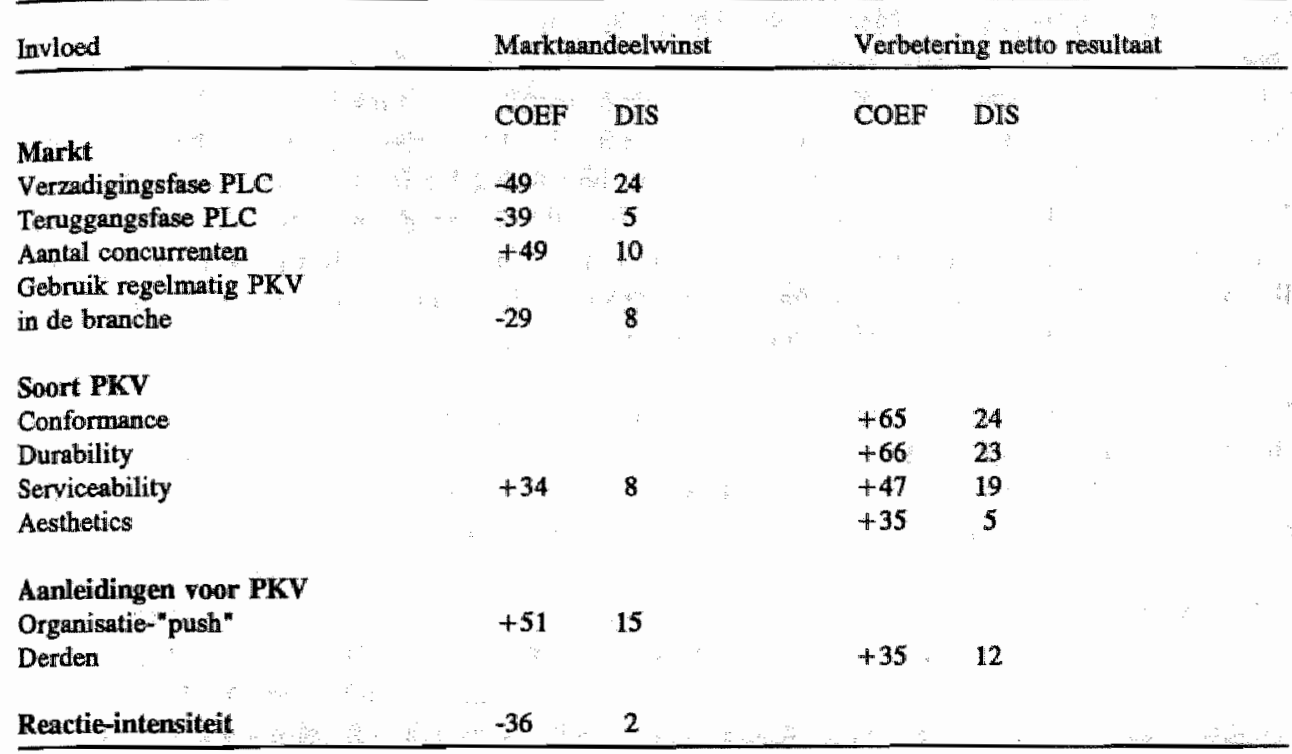

\subsubsection{Conclusies ten aanzien van het succes van PKV'n in termen van} marktaandeel en netto resultaat

Het blijkt dat wanneer ondernemingen zich bij het doorvoeren van een PKV baseren op zowel marktaspecten als technische aspecten, de marktaandeelwinst groter is en bovendien er vaker cen verbetering van het netto resultaat wordt gerapporteerd. Er bestaat een voorzichtige aanwijzing dat PKV'n gebaseerd op zowel de markt als de technische kennis succesvoller zijn dan PKV'n die niet op beide factoren zijn gebaseerd. Er is een indicatie van een positief effect op de marktaandeelwinst. De geconstateerde verschillen zijn echter statistisch gezien niet significant.

De verschillen in succes tussen de vier soorten PKV"n zijn minimaal. Het grootste succes treedt op wanneer een PKV is gebaseerd op de gebruiker of een mix van de oriëntaties produkt, produktie of gebruiker. Relatief weinig marktaandeelverbeteringen treden op wanneer de PKV is gebaseerd op produktie. Relatief weinig verbeteringen in netto resultaat treden op wanneer sprake is van PKV'n gebaseerd op bet produkt (overigens valt de helft van de PKV' $n$ in de categorie produktoriëntatie). De verschillen zijn echter niet statistisch significant.

Als concurrenten reageren binnen 6 maanden dan is het percentage ondernemingen dat

Bijlage H.2. bevat uitgebreid overzicht van de uitkomsten wan de discriminant-analyses. Dit overzicht bevat de belangrijkste variabelen, met een gestandaardiseende coefficient van do discriminantfunctie (absoluut) groter dan 0,3 of een relatief discriminatievermogen $>5 \%$. Deze lastste percentages sommeren dus in deze tabel niet tot 100 . 
een marktaandeolverhoging percipieert $59 \%$, terwijl bij reacties van meer dan eén jaar dit percentage $84 \%$ bedraagt. Snelle reacties gaan blijkbaar ten koste van de groei van het eigen marktaandeel. Ten aanzien van het netto resultaat kan de hypothese niet worden ondersteund. Snellere reacties gaan niet samen met minder ondernemingen die een verbetering van het netto resultaat bemerken.

Bij thet uitblijwen van de reactie van de concurrent percipieert ruim $73 \%$ van de ondernemingen een verbetering van het marktaandeel. Dit aandeel is $63 \%$ in het geval dat de reactie van de concurrent met meer dan én instrument heeft plaatsgevonden. Ondanks dat deze cijfers duiden op een negatief effect van de RI op de marktaandeelwinst is de relatie tussen RI en marktaandeelwinst niet duidelijk. Enerzijds vanwege de twee effecten die een rol spelen (zie 7.4.1.) en anderzijds vanwege het niet lineaire verband tussen RI en marktaandeelwinst op basis van de bivariate analyse. Bij een beduidend hogere marktaandeelwinst neemt de RI immers weer toe.

Ten aanzien van de verbetering van het netto resultaat blijkt dat de RI enigszins hoger is bij PKV' $n$ waarbii een verbetering van het netto resultaat heeft plaatsgevonden. Het verschil is echter niet statistisch significant, zodat de hypothese ten aanzien van de verbetering van het netto resultaat niet kan worden ondersteund.

Het blijkt dat op basis van bivariate toetsing slechts kan worden aangetoond dat een snelle reactie van de concurrenten de marktaandeelwinst van de initiatiefnemer tot de PKV negatief beïnvloed. Uit de multivariate analyses, die overigens zijn uitgevoerd zonder de RS als verklarende variabele, blijkt dat er toch aanwijzingen zijn dat de RI de marktaandeelwinst per saldo negatief beïnvloed. Verder blijken bepaalde soorten PKV'n de kans op marktaandeelwinst of verbetering van het netto resultaat te vergroten. Vooral wanneer PKV'n worden doorgevoerd op basis van de kracht van de eigen organisatie is de kans op marktaandeelwinst groter. Wordt de PKV gebaseerd op bijvoorbeeld certificatie-eisen van branche-organisaties of de overheid dan is de kans op een verbetering van het netto resultaat groter. De kans op een groter marktaandeel is vooral aanwezig bij een PKV die gericht is op vergroting van de service-vriendelijkheid. De kans op een toename van het netto resultaat is vooral aanwezig bij een PKV gericht op vergroting van de overeenstemming met de specificaties, de duurzaamheid en de servicevriendelijkheid. Het verbeteren van de service speelt in beide gevallen dus een belangrijke positieve rol.

Tot slot blijkt nog dat, wanneer de PLC als verklarende variabele in het model wordt gebruikt, PKV' $n$ in de verzadigings- en teruggangsfase veel minder kans op marktaandeelwinst geven dan PKV' $n$ in de introductie- of groeifase. Het effect van de PLC-fase op de verbetering van het netto resultaat is te verwaarlozen. Als het in de branche gebruikelijk is regelmatig een PKV door te voeren dan is de kans op marktaandeelwinst kleiner. Is het aantal concurrenten groter dan is de kans op marktaandeelwinst juist groter.

\subsection{Conclusies ten aanzien van produktkwaliteitswerbeteringen in een industriële markt}

De verschillende paragrafen uit dit hoofdstuk zijn telkens met een samenvatting van de gevonden resultaten afgesloten. Tevens zijn -waar mogelijk- conclusies getrokken. In deze 
slotparagraaf worden de belangrijkste conclusies op een rijtje gezet en met elkaar in verband gebracht. Wij willen benadrukken dat het onderzoek zich op de percepties van managers rond de effecten van produktkwaliteitsverbeteringen heeft gericht.

De produktkwaliteitsverbeteringen van industriële ondernemingen betreffen vooral een tweetal aspecten: een verbetering van de primaire kenmerken en prestaties van het produkt; en, de overeenstemming met de specificaties.

De aanleidingen voor de produktkwaliteitsverbeteringen van industriële ondernemingen zijn vooral gevonden in een zestal factoren, nl. marktfactoren als klantenwensen en ontevredenheid, gebruikerswensen, kwaliteitsverbeteringen bij concurrenten; technische mogelijkheden binnen de eigen organisatie; en, certificatie-eisen.

De belangrijkste concurrenten die daadwerkelijk reageren $(=70 \%$ van alle belangrijke concurrenten) concentreren hun reactie vooral op een vijftal onderwerpen, namelijk zelf ook een produktkwaliteitsverbetering doorvoeren; prijsverlagingen; de prestaties van het produkt; het ontwikkelen van nieuwe produkten; en, imagoverbeteringen door middel van reclame. $\mathrm{Zij}$ reageren gemiddeld ongeveer na tien maanden veelal zelf met een produktkwaliteitsverbetering en nog een ander instrument uit de marketing-mix.

Het totale patroon van aanleiding, produktkwaliteitsverbetering en reactie leidt ertoe dat uiteindelijk bij iets minder dan de helft van de industriẽle ondernemingen die een produktkwaliteitsverbetering initiëren een verbetering van zowel het marktaandeel als het netto resultaat optreedt. Bij iets minder dan de helft van de industriële ondernemingen is een produktkwaliteitsverbetering dus in deze twee opzichten tegelijkertijd succesvol.

Schematisch zien de hier beschreven belangrijkste aanleidingen, produktkwaliteitsverbeteringen en reacties er als volgt uit.

Schema 7.2: Belangrijkste nanleidiagen, produktkwaliteitswerbeteringen en reacties van concurrenten.

aanleidingen (6)

produktkwaliteitsverbeteringen (2)

reacties (5)

* klantenwensen

* klanten-ontevredenheid

* gebruikerswensen

* primaire kenmerken en prestaties van het produkt

* overeenstemming met specificaties

* produktkwaliteitsverbetering

- prijsverlaging

* prestaties produkt verbeteren

* nieuwe produkten ontwikkelen

produktkwaliteits-

* imago werbeteren door middel reciame

ondernemingen

* technische mogelijkheden

in de eigen orgunisatie

- certificatie-eisen

Deze opsommingen van de afzonderlijke aanleidingen, produktkwaliteitsverbeteringen en reacties geven nog niet aan welke specifieke combinaties voorkomen. Op de globale en specifieke combinaties van actie en reactie zal nu nader worden ingegaan.

Wanneer in globale zin de samenhang in het actie en reactiepatroon rond produktkwaliteitsverbeteringen geanalyseerd wordt, blijkt dat op dit globale niveau een aantal patronen voorkomen. Eén van de meest voorkomende patronen bestaat uit: 
* Een produktkwaliteitsverbetering bij een industriéle onderneming, welke aanleiding is voor:

* Een kwaliteitsverbetering bij de onderneming in kwestie, welke weer gevolgd wordt door:

* Een produktkwaliteitsverbetering door de belangrijkste concurrent.

Minimaal $45 \%$ van de geïnitieerde produktkwaliteitswerbeteringen wordt beantwoord met een produktkwaliteitsverbetering. (Hierbij zij aangetekend dat bij dit centrale patroon ook nog andere aanleidingen en reactie-instrumenten kunnen voorkomen; deze drie elementen geven de kern van het patroon weer).

Per type produktkwaliteitsverbetering blijkt een aantal specifieke actie en reactiepatronen herkenbaar te zijn. Een vijftal specifieke patronen zijn te ontdekken.

Meer gedetailleerd blijkt dat een produktkwaliteitsverbetering welke specifiek gericht is op het verbeteren van de primaire kenmerken en prestaties van het produkt (dit geldt in meer dan $50 \%$ van de gevallen), relatief vaak veroorzaakt wordt door een produktkwaliteitsverbetering bij concurrenten en relatief vaak beantwoord wordt met een verbetering van de prestaties van concurrerende produkten. Met andere woorden, ten aanzien van het verbeteren van de primaire kenmerken en prestaties van industriële produkten bestaat een duidelijk actie en reactiepatroon met en rond deze primaire kenmerken en prestaties. Men reageert op elkaar met een steeds hoger kwaliteitsniveau van deze kenmerken. Deze reacties zijn minder snel dan gemiddeld en iets intensiever dan gemiddeld. Bij deze acties en reacties is geen duidelijke uitspraak te doen over het effect op het marktaandeel of het netto resultaat. Dit komt wellicht door de reactie van concurrenten waardoor weer een "evenwichtssituatie" bereikt wordt, en de status quo wordt hersteld.

$\mathrm{Er}$ is wel een positief effect op het marktaandeel en het netto resultaat van de initiator van een produktkwaliteitsverbetering waarneembaar wanneer deze verbetering mede en vooral de service rond het produkt betreft. Het is hierbij cruciaal dat de initiatiefnemer de noodzaak hiertoe onderkent op grond van de behoefte bij de klanten. De initiatiefnemer kan aldus een concurrentieel voordeel krijgen. Dit kan redelijk lang stand houden aangezien de belangrijkste concurrenten de initiator wel imiteren maar dit niet zo snel doen. Gemiddeld reageren zij pas na 17 maanden op een tamelijk intensieve wijze.

Zeer intensieve maar ook erg laat optredende reacties van concurrenten vinden plaats bij een produktkwaliteitsverbetering die (ook) de reputatie van de onderneming en meer ongrijpbare elementen betreft (perceived quality). Deze reacties vinden niet alleen plaats in de vorm van produktverbeteringen maar vooral ook in de vorm van prijsverlagingen en het ontwikkelen van nieuwe produkten. Deze produktkwaliteitsverbeteringen komen bij de initiator vooral ook voort uit veranderingen in de eigen organisatie en de eigen technische mogelijkheden. Zulke aanleidingen zorgen nogal eens voor een significante marktaandeelwinst voor de initiator.

Gebruikerswensen zijn in sterkere mate dan gemiddeld de aanleiding voor het verbeteren van de secundaire eigenschappen van het industriële produkt. De belangrijkste concurrenten reageren relatief vaak met het ontwikkelen van nieuwe produkten en verhoging van de promotie-uitgaven. Deze reacties vinden vrij snel en erg intensief plaats. Een duidelijk effect op het marktaandeel of het netto resultaat als gevolg van dezeverbetering is niet waarneembaar (wellicht door de aard van de reactie).

Voor het verbeteren van de vormgeving is geen specifieke aanleiding gevonden; de belangrijkste concurrenten reageren vrij snel, maar niet intensief. $\mathrm{Zij}$ proberen via 

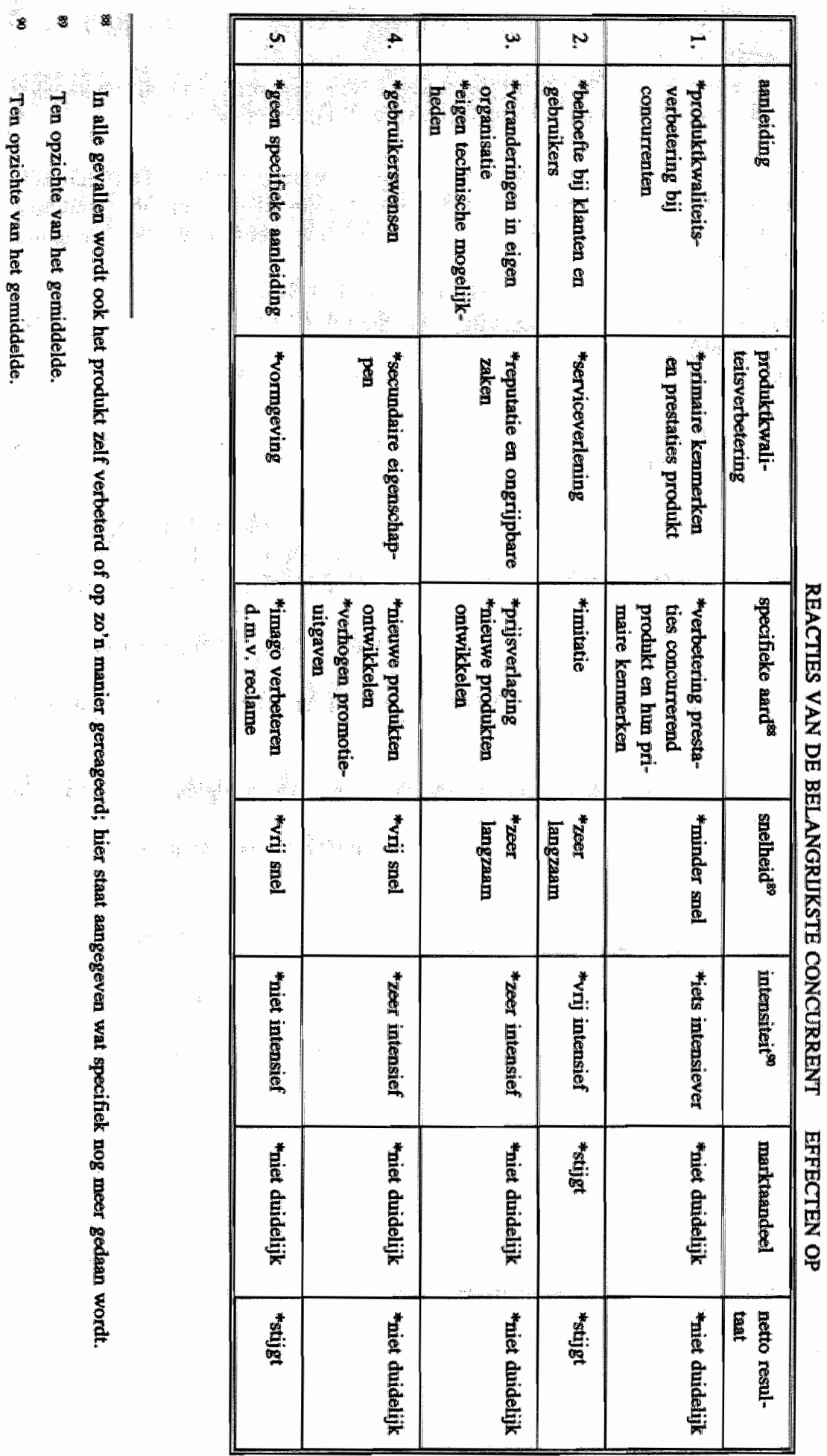

है

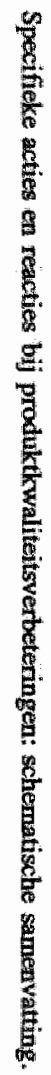


reclame hun imago te verbeteren. Het voorgaande is kort weergegeven in schema 7.3 .

Over de interisiteit waarmee de belangrijkste concurrenten reageren kan geconcludeerd worden dat deze vooral groter is naarmate de produktkwaliteitsverbeteringen:

* In sterkere mate mogelijk gemaakt worden door veranderingen in de organisatie van de initiatiefnemer, wanneer de technologische ontwikkeling in die organisatie. daar mogelijkheden toe biedt en zij de beschikking heeft over de benodigde financięle middelen.

* In grotere mate de betrouwbaarheid van het produkt betreffen.

* Plaatsvinden in een branche waarin het gebruikelijker is regelmatig zulke verbeteringen aan te brengen.

* Plaatsvinden in branches waarin het aantal concurrenten groter is.

Het succes van een produktkwaliteitsverbetering in termen van een groter marktaandeel is in positieve zin sterk afhankelijk van:

* Organisatie-"push" aanleidingen (de reactie blijkt niet zo snel te komen).

* Een groter aantal concurrenten in de branche (wellicht is van hen dan gemakkelijker een "klein stukje marktaandeel" te veroveren dan bij een beperkter aantal concurrenten).

* Een produktkwaliteitsverbetering die vooral ook de serviceverlening betreft.

Het succes in termen van een groter marktaandeel wordt in negatieve zin sterk beĩnvloed door:

* Het feit of het produkt zich in de verzadigings- of teruggangsfase van de levenscyclus bevindt.

* Het gebruik in de branche om regelmatig produktkwaliteitsverbeteringen door te voeren.

Een produktkwaliteitsverbetering leidt vooral tot cen beter netto resultaat wanneer:

* De verbetering vooral de duurzaamheid, de serviceverlening en de overeenstemming met de specificaties betreft.

* De aanzet tot de produktkwaliteitsverbetering vooral gegeven wordt door derden (certificatie-eisen, branche, overheid e.d.).

Met andere woorden, vooral de produktkwaliteitsverbeteringen die ook de serviceverlening rond het industriële produkt betreffen, lijken succesvol te zijn, zowel in termen van marktaandeelvergroting als in termen van stijging van het netto resultaat. Hierbij bleek al eerder dat de belangrijkste concurrenten niet zo snel reageren. Cruciaal lijkt wel het onderkennen van de behoefte aan serviceverlening omdat imitatie volgt. Degenen die een dergelijke klant- en/of marktgerichtheid ten toon spreiden en vertalen in servicekwaliteitsverbeteringen worden daarvoor beloond met een groter marktaandeel en een hoger netto resultaat. 
De produktlevenscyclus is in het voorgaande al herhaaldelijk naar voren gekomen als een kenmerk van de industriële onderneming en haar markt die medebepalend is bij de kenmerken en resultaten van produktkwaliteitsverbeteringen. Over deze samenhang zullen -als afsluiting van deze paragraaf- de belangrijkste conclusies gepresenteerd worden. Het blijkt dat:

* De produktkwaliteitsverbeteringen in alle fasen voor ongeveer $50 \%$ de primaire kenmerken en prestaties van het produkt zelf betreffen.

* De produktkwaliteitsverbeteringen in de eerdere fasen op een groter aantal onderwerpen betrekking hebben dan in de latere fasen. Het gaat in het bijzonder ook om de secundaire produktkenmerken en de serviceverlening die verbeterd worden in het begin van de levenscyclus.

* De produktkwaliteitsverbeteringen in de latere fasen (verzadiging en teruggang) in het bijzonder ook efficiency verbeteringen in de produktie betreffen, die de kwaliteit van het produkt ten goede komen. Het betreft hier immers ook nog wel eens een betere overeenstemming met de specificaties.

* De reactie in de verzadigingsfase vaker met meer "ongrijpbare" elementen plaatsvindt (dan in de andere fasen).

* De intensiteit van de reactie van de belangrijkste concurrenten in de teruggangsfase lager is dan die in de andere fasen.

* De produktkwaliteitsverbeteringen in de eerdere fasen een grotere kans bieden op een verbetering van het marktaandeel, terwijl een produktkwaliteitsverbetering in de latere fasen een kleinere kans biedt op een verbetering van het marktaandeel.

* Er geen verschil is tussen de fasen van de produktlevenscyclus en de verandering in het netto resultaat als gevolg van de produktkwaliteitsverbetering.

Alle analyses overziend kan geconcludeerd worden dat een produktkwaliteitswerbetering door industriële ondernemingen weinig zin heeft wanneer het produkt zich in de verzadigings- of teruggangsfase van de levenscyclus bevindt en beoogd wordt een verbetering van het marktaandeel of het netto resultaat te verkrijgen. Daar is het dan blijkbaar te laat voor. Verbeteringen, met een dergelijk doel, zijn alleen zinvol en succesvol in de introductie- en groeifase. 


\section{Mogelijke verklaringen en suggesties voor verder onder- zoek}

De resultaten van het empirische onderzoek zullen achtereenvolgens worden samengevat rond cen aantal onderwerpen, waarbij tevens een relatie wordt gelegd met de theorie en empirische resultaten uit andere onderzoeken. Het is geenszins de bedoeling een compleet overzicht van de resultaten te geven. Dat is in de voorafgaande hoofdstukken reeds gebeurd. De onderwerpen zijn zo gekozen dat de belangrijkste conclusies nogmaals worden verwoord en in de context van andere literatuur worden gebracht. De onderwerpen zijn achtereenvolgens:

1. De kenmerken van de ondernemingen.

2. Oligoploïde markten en reactie-intensiteit.

3. Fase in de produktlevenscyclus en reactie-intensiteit.

4. Soorten produktkwaliteitsverbeteringen en reactie-intensiteit.

5. Het succes van produktkwaliteitsverbeteringen.

6. Markttoetredingen en produktkwaliteitsverbeteringen.

7. Marktgerichte produktkwaliteitsverbeteringen.

Tot slot wordt (in 8.8.) een aantal suggesties voor verder onderzoek gegeven.

\subsection{De kenmerken van de ondernemingen}

In de marketing-strategie van de ondernemingen krijgt kwaliteit het hoogste gewicht, gevolgd door service en prijs. In de eerste fasen van de produktlevenscyclus krijgt het service-aspect relatief veel aandacht en in de latere fasen de prijs. Doordat de produkten in de latere fasen van de produktlevenscyclus uitontwikkeld zijn ligt de nadruk op prijsconcurrentie; in de eerste fasen kan, vooral in een industriële markt, nog sprake zijn van technische problemen die door middel van service verholpen dienen te worden. Deze conclusies zijn vergelijkbaar met onderzoeksresultaten van Staples, Baker \& Sweeney (1976) en Wasson (1978). Het gemiddeld aantal produktkwaliteitsverbeteringen per onderneming over een periode van vijf jaar is kleiner in de verzadigingsfase dan in de groeifase van de produktlevenscyclus. Dit impliceert dat de kwaliteitsconcurrentie wellicht minder belangrijk is in de verzadigingsfase. Op basis van de suggestie van Wasson (1978) dat er in de latere fasen van de produktlevenscyclus weinig technische mogelijkheden meer zijn om produktkwaliteitsverbeteringen door te voeren is onze bevinding verklaarbaar. Echter, in de teruggangsfase constateren wij weer een toename van het gemiddeld aantal produktkwaliteitsverbeteringen. Wellicht is deze toename te verklaren door de zogenaamde quasi-kwaliteitsverbeteringen, omdat eveneens in ons onderzoek relatief meer ongrijpbare produktkwaliteitsverbeteringen in de latere fasen van de produktlevenscyclus worden doorgevoerd. Deze vinden dan niet plaats in de verzadigingsfase plaats, zoals Wasson veronderstelt, maar in de teruggangsfase. 


\subsection{Oligopoloüde markten en reactie-intensiteit}

De veronderstelling is dat ondernemingen die opereren op oligopoloïde markten vanwege hun strategische afhankelijkheid geneigd zijn sterker te reageren op acties van concurrenten dan ondernemingen die op markten opereren met een veelheid aan concurrenten. Met andere woorden, in ons onderzoek (waarin overigens tweederde van de ondernemingen minder dan 11 concurrenten percipieert) wordt verwacht dat de reactieintensiteit lager zal zijn naarmate het aantal concurrenten groter is.

Het blijkt echter in ons onderzoek dat een positief verband bestaat tussen het aantal concurrenten waarmee de onderneming daadwerkelijk concurreert en de reactie-intensiteit. Een mogelijke verklaring hiervoor is dat ondernemingen met een groot aantal concurrenten één of enkele concurrenten nauwgezet volgen omdat dat hun belangrijkste concurrenten zijn. In feite creëren ondernemingen bij het nemen van beslissingen een subpopulatie van concurrerende ondernemingen waarbinnen op deze wijze eveneens strategische afhankelijkheid ontstaat.

\subsection{Fase in de produktlevenscyclus en reactie-intensiteit}

De reactie-intensiteit is in de teruggangsfase van de produktlevenscyclus lager dan in de verzadigingsfase van de produktlevenscyclus, en in een groeiende markt niet afwijkend van de reactie-intensiteit in een verzadigde markt. Vanwege het belang van het verdringingseffect werd verondersteld dat in de verzadigingsfase (en om die reden eveneens in de teruggangsfase) de reactie-intensiteit hoger zou zijn dan in de groeifase. In onderzoek naar markttoetredingen (Biggadike 1979, Robinson 1988) is gevonden dat de reactie-intensiteit in de groeifase zelfs aanmerkelijk hoger was dan in de verzadigingsfase. Weliswaar wijkt in onze studie de reactie-intensiteit in de groeifase niet af van de verzadigingsfase, maar de verwachting was dat de reactie-intensiteit in de groeifase lager zou zijn. De volgende verklaringen (voor wat betreft de punten 2, 3 en 4 gebaseerd op Robinson's verklaring van de reactie-intensiteit in de context van markttoetredingen) kunnen worden gegeven yoor onze bevindingen:

1) De concurrentiedruk is in de teruggangsfase vanwege de "shake-out" in de verzadigingsfase sterk verminderd. Daarnaast is het mogelijk dat ondernemingen gedwongen zijn geweest om een eigen marktnis te creëren en te bewerken waar eveneens een beschermende invloed tegen de concurrentie vanuit gaat. Enige ondersteuning van deze verklaring is te vinden in het gewicht dat ondernemingen in ons onderzoek toekennen aan een marktnisstrategie. Dit gewicht is het hoogst in de teruggangsfase van de produktlevenscyclus.

2) Produktkwaliteitsverbeteringen in groeiende markten kunnen mogelijkheden blootleggen waar de concurrenten tot nog toe aan voorbij zijn gegaan. Dat duidt op een intensievere reactie doordat imitatie door de concurrentie plaatsvindt. In ons onderzoek blijkt dat de relatieve concurrentiële reactie met behulp van eveneens produktkwaliteitsverbeteringen in de groeifase enigszins lager is dan in de verzadigingsfase. De reactie met verbeteringen van de prestaties van het produkt en de ontwikkeling van nieuwe produkten komt relatief vaker voor in de groeifase van de produktlevenscyclus dan in de verzadigingsfase. 
3) Reacties worden beïnvloed door verschillen tussen verwachte en werkelijke verkopen (Aaker \& Day 1986). Dat reacties niet worden beinnvloed door de absolute verkopen, maar door relatieve verkopen (bijvoorbeeld afzetgroei en marktaandeel) werd al door Alemson (1969) betoogt. Door steeds betere marktinformatiesystemen is deze informatie snel en eenvoudig beschikbaar en wordt dus ook gebruikt voor beslissingen ten aanzien van concurrentiële reacties op produktkwaliteitsverbeteringen. Wanneer een concurrent succes heeft met een produktkwaliteitsverbetering wordt dit meteen duidelijk en volgt een reactie. Uit empirisch onderzoek naar markttoetredingen blijkt dat reacties in groeimarkten voorkomen als het marktaandeel van de reeds aanwezige concurrenten afneemt (Bevan 1974).

4) Groeimarkten zijn relatief jong, en meestal veelbelovend. De toekomstige mogelijkheden zijn in de regel groot; en derhalve een strategische investering in een reactie op produktkwaliteitsverbeteringen waard.

5) Ondernemingen in een groeimarkt worden vaak op een andere wijze bestuurd dan ondernemingen in een verzadigings- of teruggangsfase. Er zijn vaak meer middelen beschikbaar en de flexibiliteit ten aanzien van de inzet van middelen is groter. In het algemeen is het eenvoudiger van vastgestelde budgetten of plannen af te wijken (zie ook Frey 1988) en dus ook om adequaat te reageren op produktkwaliteitsverbeteringen.

\subsection{Produktkwaliteitsverbeteringen en reactie-intensiteit}

Produktkwaliteitsverbeteringen gebaseerd op "reliability" worden beantwoord met een intensieve reactie van de concurrent. Blijkbaar wordt een produktkwaliteitsverbetering met als doel de verbetering van de betrouwbaarheid gezien als een ernstige bedreiging waar een intensieve reactie bij past. Uit onderzoek uit verschillende disciplines, zoals kwaliteitszorg, industriële marketing en dienstenmarketing (Juran 1974, Van Weele \& Frequin 1986, Zeithaml, Berry \& Parasuraman 1990, Berry, Zeithaml \& Parasuraman 1990) blijkt dat de betrouwbaarheid van produkten en diensten door klanten als de belangrijkste kwaliteitsdimensie wordt gezien. Door een produktkwaliteitsverbetering gebaseerd op verbetering van de betrouwbaarheid van het produkt kan blijkbaar een groot concurrentieel voordeel behaald worden dat mede leidt tot een versteviging van de relatie met de klant. Een sterke relatie, zeker in de industriële sfeer, is moeilijk te doorbreken voor concurrenten en vormt dus een soort toetredingsbarrière. Tevens vormt dit een exitbarrière voor de klant. Zoeken van een andere leverancier brengt namelijk ook vaak hoge transactiekosten met zich mee. Concurrenten worden op deze wijze geïsoleerd van (potentiële) klanten en reageren dan met de inzet van diverse instrumenten.

De aanleidingen voor produktkwaliteitsverbeteringen zijn eveneens een belangrijke verklarende factor als het gaat om de reactie-intensiteit van de concurrent. Wanneer produktkwaliteitsverbeteringen het resultaat zijn van veranderingen in de organisatie dan is de reactie-intensiteit hoog. Dat is ook het geval wanneer de produktkwaliteitsverbetering de resultante is van concurrentiële acties. In die gevallen is de produktkwaliteitsverbetering waarschijnlijk dusdanig ingrijpend binnen de eigen organisatie gesteund, respectievelijk "zichtbaar" dat de concurrentie het noodzakelijk vindt hier intensief op te reageren. 


\subsection{Het succes van produktkwaliteitsverbeteringen}

Uit de PIMS-onderzoeken komt duidelijk naar voren dat cen sterke relatieve kwaliteitspositie ten opzichte van de concurrenten leidt tot een hoger marktaandeel en een hogere ROI (Schoeffler, Buzzel \& Heany 1974, Jacobson \& Aaker 1987). Uit ons onderzoek blijkt dat produktkwaliteitsverbeteringen in meer dan de helft van de gevallen leidt tot een hoger marktaandeel of een hoger netto resultaat (in de perceptie van de ondernemer). In $48 \%$ van de gevallen leidt een produktkwaliteitsverbetering tot een hoger marktaandeel en een hoger netto resultaat.

Het succes van produktkwalliteitswerbeteringen in termen van marktaandeelwinst wordt voornamelijk door een zevental factoren bepaald: de fase in de produktlevenscyclus (verzadigings- of teruggangsfase of niet), het gebruik in de branche ten aanzien van de frequentie van de produktkwaliteitsverbeteringen, het antal concurrenten, de soort produktkwaliteitsverbetering ("serviceability"), aanleiding voor de produktkwaliteitsverbetering (organisatie-"push"), de reactie-intensiteit en de reactiesnelheid.

Produktkwaliteitsverbeteringen in de verzadigings- of teruggangsfase hebben een kleinere kans op een hoger marktaandeel dan produktkwaliteitsverbeteringen in de introductie- of groeifase. Specifiek voor de teruggangsfase is een tweetal onderzoeken bekend die gaan over de kenmerken van ondernemingen die succesvol uit deze fase tevoorschijn komen.

Uit onderzoek van Grinyer, Mayes \& McKiernan (1988) blijkt dat er ten aanzien van de maatregelen ter verbetering van de kwaliteit en de service nauwelijks verschil bestaat tussen succeswolle en minder succesvolle ondernemingen. Produktkwaliteitsverbeteringen dragen dus in de teruggangsfase, ook in ons onderzoek, niet expliciet bij tot verbetering van het marktaandeel.

Produktkwaliteitsverbeteringen gebaseerd op "perceived quality", waar onder wij ook assortimentsverbreding rekenen, komen vooral voor in de latere fasen van de produktlevenscyclus. Deze produktkwaliteitsverbeteringen leiden in ons onderzoek tot een enigszins grotere kans op succes als het gaat om verbetering van het marktaandeel. Dit lijkt in overeenstemming met bevindingen uit Nederlands onderzoek naar de verschillen tussen succesvolle en minder succesvolle ondernemingen in neergaande markten (Schreuder, Van Cayscele, Jaspers \& De Graaff 1988, Nationale Investeringsbank 1989). Meer succesvolle ondernemingen nemen maatregelen ten aanzien van de markt en het produktassortiment, en doen dit frequenter.

De genoemde bevindingen sluiten echter niet vit dat het in het algemeen zinvol kan zijn in de verzadigings- en teruggangsfase produktkwaliteitsverbeteringen door te voeren om de status quo te handhaven en verslechtering van het marktaandeel te voorkomen. Vooral produktkwaliteitsverbeteringen gebaseerd op de "serviceability" lijken nogal eens succesvol te zijn ten aanzien van de vergroting van het marktaandeel. Meestal worden dergelijke kwaliteitsverbeteringen gebaseerd op de kracht van eigen organisatie.

In het algemeen blijkt dat ook produktkwaliteitsverbeteringen doorgevoerd naar aanleiding van omstandigheden of sterke punten binnen de organisatie eveneens de kans op een hoger marktaandeel vergroten. Is er voldoende interne steun in de vorm van kapitaal, technische mogelijkheden en een aangepaste organisatie, dan wordt het voor de concurrent waarschijnlijk moeilijk om snel en adequaat te reageren en is het effect op vergroting van het marktaandeel substantieel.

Wordt de produktkwaliteitsverbetering gebaseerd op concurrentiële acties dan heeft de produktkwaliteitsverbetering een kleinere kans op een hoger marktaandeel. De betreffende 
produktkwaliteitsverbetering is dan waarschijnlijk defensief, omdat wordt gereageerd op een andere concurrent. De markt is reeds in beweging en de onderneming met de produktkwaliteitsverbetering kan dan gekenschetst worden als volger, die genoegen moet nemen met de minder aantrekkelijke delen van de markt. Bovendien blijkt in dat geval de intensiteit van de concurrentiele reactie groter te zijn. Samen resulteert dit in een kleinere kans op een groter marktaandeel.

Produktkwaliteitsverbeteringen op basis van "serviceability" verhogen de kans op een hoger marktaandeel. In industriële markten blijkt dat ook service, naast de betrouwbaarheid van het produkt, in belangrijke mate bijdraagt aan het succes van de onderneming in termen van marktaandeel. Uit het eerder genoemde onderzoek (Gummesson 1987, Parasuraman, Zeithaml \& Berry 1990) blijkt het belang van bijvoorbeeld betrouwbaarheid en service voor ondernemingen die opereren op industriële markten. Concurrenten reageren niet snel en trachten de service te imiteren. Verbeteringen van de service worden vooral doorgevoerd op basis van behoefte bij klanten en gebruikers. Waarschijnlijk is het moeilijk deze behoefte te onderkennen omdat het om serviceverbeteringen in de eerste fasen van de levenscyclus lijkt te gaan. In dit verband is het relevant te bedenken dat industriële ondernemingen in het algemeen veelal produktgericht zijn en niet zo klantgericht. $\mathrm{Zij}$ denken meer uit hun eigen achtergrond over produkt en service dan vanuit de klant.

Het is in dit verband dus eveneens van belang marktgericht te opereren. Samengevat blijkt dus dat produktkwaliteitsverbeteringen ten aanzien van service-aspecten succesvol blijken te zijn als het gaat om marktaandeelwinsten.

Reacties van concurrenten leiden tot een kleinere kans op een hoger marktaandeel. Het negatieve effect van de reactie-intensiteit op de vergroting van het marktaandeel is gemiddeld; het onderscheidend vermogen tussen de wel en niet succesvolle bedrijven is echter minimaal. Dit is het tegenovergestelde van de bevindingen van Biggadike, waarin bij uitblijven van de reactie van de concurrent een lagere marktaandeelwinst wordt gerealiseerd dan bij een reactie van de concurrent. De resultaten van Biggadike waren echter nauwelijks statistisch significant ${ }^{91}$. Op basis van ons onderzoek moet worden geconcludeerd dat, in tegenstelling tot de conclusie van Biggadike, het negatieve effect van de reactie-intensiteit op de vergroting van het marktaandeel wel aanwezig is. Het is eveneens duidelijk dat snelle reacties een negatieve invloed op de marktaandeelwinst uitoefenen.

Het succes in termen van netto resultaat kan voornamelijk worden verklaard uit de soort produktkwaliteitsverbetering en het wel of niet baseren van de produktkwaliteitsverbetering op derden, zoals certificatie-eisen van branche-organisaties en/of overheidsregelingen.

Produktkwaliteitsverbeteringen gebaseerd op "conformance", "durability", "serviceability" zijn belangrijk voor de verklaring van het netto resultaat. Wanneer de nadruk van de produktkwaliteitsverbetering ligt op één of meer van die soorten produktkwaliteitsverbeteringen, dan is er een grotere kans op een verbetering van het netto resultaat.

Wanneer de produktkwaliteitswerbetering is doorgevoerd naar aanleiding van signalen van derden (certificatie-eisen, overheid) dan is de kans op een positief resultaat eveneens groter. De reactie-intensiteit van de concurrent speelt in dit verband nauwelijks een rol. In 
Biggadike's onderzoek bleek dat wanneer de concurrent niet reageerde het netto resultaat (gedefinieerd als ROD) enigszins hoger was. Wederom was het verschil in Biggadike's onderzoek, evenals nu in ons onderzoek, tussen wel en niet reageren niet statistisch significant.

In het algemeen kan worden geconcludeerd dat het succes van produktkwaliteitsverbeteringen in termen van netto resultaat afhankelijk is van de soort produktkwaliteitsverbetering. De kanis op een hoger netto resultaat neent toe als de produktkwaliteitsverbeteringen zijn doorgevoerd naar aanleiding van signalen van de overheid of certificatie-eisen van derden (branche-organisaties). Ondernemingen die op basis hiervan produktkwaliteitsverbeteringen hebben doorgevoerd zijn blijkbaar succesvoller (in termen van netto resultaat) dan ondernemingen die dit niet hebben gedaan. Waarschijnlijk ligt dit effect meer aan de kostenkant door de met de produktkwaliteitsverbeteringen gepaard gaande efficiency-verbeteringen. Een andere indicatie hiervoor is het belang van de overeenstemming met de specificaties; dat is meer interen gericht en beïnvloedt het netto resultaat in positieve zin. Verder lijkt het netto resultaat niet afhankelijk te zijn van marktfactoren, als fase in de produktlevenscyclus, aantal concurrenten, marktaandeel etc.. Dus ongeacht bijvoorbeeld de fase in de produktlevenscyclus leiden de beschreven produktkwaliteits-verbeteringen tot een hoger netto resultaat.

Ten opzichte van Biggadike's onderzoek valt resumerend ten aanzien van de reactieintensiteit de volgende conclusie te trekken. Biggadike concludeerde dat de reactie(intensiteit) van de concurrent geen invloed uitoefende op het succes van de markttoetreding, zowel in termen van marktaandeel als netto resultaat. In ons onderzoek naar produktkwaliteitsverbeteringen speelt de reactie-intensiteit een negatieve rol bij de marktaandeelwinst en is deze niet van betekenis voor het netto resultaat. De reactiesnelheid is met name van invloed op de marktaandeelwinst. Snelle concurrentiële reacties verkleinen de kans op marktaandeelwinst.

\subsection{Markttoetredingen en produktkwaliteitsverbeteringen}

Of reactie-intensiteiten bij markttoetredingen groter zijn dan bij produktkwaliteitsverbeteringen kan aan de hand van ons onderzoek worden getoetst. Gelet op de aard van de actie, veroorzaken markttoetredingen in de regel grotere verschuivingen in de markt dan produktkwaliteitsverbeteringen. Het lijkt dan ook aannemelijk dat de intensiteit van de reactie groter is. Markttoetredingen zijn onder andere empirisch onderzocht door Biggadike (1979) en Robinson (1988). Biggadike rapporteert dat in $46 \%$ van de gevallen geen concurrentièle reactie optreedt. Robinson komt tot 54\% (zie tabel 8.1.). Het aantal ondernemingen dat geen reactie rapporteert ligt dus in ons onderzoek beduidend lager $(30 \%)$. Blijkbaar gaat van een produktkwaliteitsverbetering een belangrijke dreiging uit en is een produktkwaliteitsverbetering voor de concurrentie zo "zichtbaar", dat directe concurrenten zich genoodzaakt voelen te reageren.

Ter vergelijking met Biggadike's cijfers moet opgemerkt worden dat in ons onderzoek meer instrumenten per waarneming worden aangeven en dat het aantal respondenten dat drie of meer marketing-mix instrumenten aangeeft $9 \%$ is van het totaal (Biggadike 5\%). De belangrijkste produktreacties in ons onderzoek zijn produktkwaliteitsverbeteringen (inclusief prestaties van het produkt) en het ontwikkelen van een nieuw produkt. Vergelijking van de soorten reacties leert dat het aantal reacties met prijs en promotie op 
eenzelfde niveau liggen. Produktkwaliteitsverbeteringen leiden tot minder reacties met wijzigingen in distributie en tot meer reacties met produktwerbeteringen. Een verklaring zou kunnen liggen in het feit dat wijzigingen in distributie normaliter nogal ingrijpend zijn. Een dergelijke reactie is dan eerder te verwachten bij markttoetredingen. Resteert de hogere reactie met het marketing-mix instrument produkt. Een voorzichtige conclusie is dat de reactie met het instrument produkt zeker niet lager is dan bij markttoetredingen, en dat de inzet van het prijs- en promotie-instrument vergelijkbaar is.

Tabel 8.1.: Spreiding van de reacties naar instumenten en intensiteit.

Aantal instrumenten, uitgaande van vierdeling in groepen: produkt(1), promotie $e^{22}(2)$, prijs(3) en distributie(4).

\begin{tabular}{llllll} 
& Geen & Een: & Twee: & Drie & Vier \\
\hline Biggadike $(\mathrm{n}=37)^{94}$ & $46 \%(3-6 \%)$ & onbekend & & \\
Robinson $(\mathrm{n}=115)^{9 \%}$ & $54 \%(3 \%)$ & $27 \%$ & $11 \%$ & $3 \%$ & $2 \%$ \\
Ons onderzoek $(\mathrm{n}=198):$ & $30 \%$ & $37 \%$ & $23 \%$ & $8 \%$ & $1 \%$ \\
\hline
\end{tabular}

Reacties per marketing-mix instrumentgroep:

\begin{tabular}{lllll} 
& Produkt: & Promotie: & Prijs: & Distributie: \\
\hline & & & & \\
Biggadike $(\mathrm{n}=37):$ & $24 \%$ & $32 \%$ & $22 \%$ & $11 \%$ \\
Robinson $(\mathrm{n}=115):$ & $20 \%$ & $18 \%$ & $24 \%$ & $7 \%$ \\
Ons onderzoek $(\mathrm{n}=198):$ & $60 \%$ & $23 \%$ & $25 \%$ & $1 \%$ \\
\hline
\end{tabular}

In de industriele economie literatuur wordt vaak gesproken over marketing uitgaven. Dit ajun uitgaven ten behoeve van promotie, reclame en verkoop. Er is in deze tabel angenomen dat dê door ons onderscheiden categorie promotie vergelijkbaar is.

Biggadike en Robinson ondenscheiden ook "accomodating" rescties; reacties die niet do markttoetreding tegenwerken, maar ondersteunen. In beide studies wordt in maximaal 5 \% van de gevallen een dergelijke reactie gerapporteerd. In deze tabel worden dese reacties niet expliciet meegenomen, omdat in ons onderzoek dit type reactie niet is geinventariseerd, behalwe bij prijs. De percentages "accomodating" reacties staan apart vermeld (tussen halkjes) onder de categorie "geen", en zijn niet opgenomen onder het percentage bij "geen".

De door Biggadike onderscheiden categorie "verandering van de capaciteit" is buiten beschouwing gelaten.

Door een andere wijze van berekening is de verdeling over het aaintal instrumenten uit het onderzoek van Biggadike onbekend.

Reacties door én van de drie bellangrijkste reeds aanwezige concurrenten met het betreffende instrument, binnen 2 jaar na markttoetreding. 
Bij de conclusies moeten enkele relativerende opmerkingen worden gemaakt, omdat bij deze vergelijkingen niet wit het oog mag worden verloren dat in de onderzoeken van Biggadike en Robinson een deel van de waarnemingen uit een andere markt, de consumentenmarkt, komt, en dat de reactie gemeten is bij een drietal concurrenten, en niet bij cên (belangrijkste) concurrent, zoals in ons onderzoek het geval is. Bovendien heeft de omvangrijke reactie met produktverbeteringen in ons onderzoek betrekking op het hele scala van marginale produktverbeteringen tot en met het ontwikkelen van een nieuw produkt. Het is onzeker of in de onderzoeken van Biggadike en Robinson de rol van het marketing-mix instrument wel zo breed is opgevat. Uit de vraagstelling en rapportering blijkt evenwel dat het gaat om met onze indeling vergelijkbare grootheden.

De conclusie uit de vergelijking met markttoetredingen is dat de concurrentiële reactieintensiteit niet minder is dan bij markttoetredingen. Blijkbaar volgen ondernemingen de concurrentiële produktkwaliteitsverbeteringen nauwkeurig en reageren alert. De typische reactie is wel een reactie met één of meer marktinstrumenten, met een sterke nadruk op eveneens produktkwaliteitsverbeteringen, maar tevens in een niet onaanzienlijk deel van de gevallen met prijsverlagingen of aanpassingen in promotie- of reclameuitgaven.

\subsection{Marktgerichte produktk waliteitswerbeteringen}

Naar analogie van de inhoud van het marketing-concept is een produktkwaliteitsverbetering (in paragraaf 2.6.3.) omschreven als een zodanige verbetering van het tastbare produkt, inclusief door de consument toegevoegde eigenschappen dat in sterkere mate wordt tegemoet gekomen aan de wensen en/of behoeften van de klant. Daarbij wordt rekening gehouden met de relatieve kwaliteitspositie ten opzichte van de concurrentie en de interne afstemming binnen het produktie(voortbrengings-)proces. Bij de indeling in soorten produktkwaliteitsverbeteringen bleek al dat een deel van de produktkwaliteitsverbeteringen was te omschrijven als produktgeoriënteerd, een deel als produktiegeoriënteerd en een deel als gebruikersgeoriënteerd. Van veel ondernemingen zijn de produktkwaliteitsverbeteringen te karakteriseren in termen van produkt, produktie en/of de gebruiker. Bij nadere beschouwing van de exacte omschrijvingen van de produktkwaliteitsverbeteringen bleek dat de concurrentie slechts bij én produktkwaliteitsverbetering ${ }^{\$ 7}$ blijkbaar zo nadrukkelijk aanwezig was dat deze expliciet werd genoemd. Bij veel ondernemingen krijgt dus de concurrentie in het kwaliteitsconcept niet die prominente plaats die het in het marketing-concept sinds het begin van de jaren tachtig inneemt. Wordt de concurrentie als aanleiding genoemd voor produktkwaliteitsverbeteringen dan blijkt dat daardoor de reactie-intensiteit hoger is en de kans op een hoger marktaandeel kleiner is. Waarschijnlijk is men, als de aanleiding gevonden wordt bij de concurrentie, te laat met het verbeteren van de produktkwaliteit (men is "volger") en is de reactie defensief.

De relatieve kwaliteitspositie ten opzichte van de concurrentie die hiervoor wordt beschreven als onderdeel van produktkwaliteitsverbeteringen moet dan ook meer proactief dan reactief worden begrepen. De oriëntatie op de concurrent moet dus eerder als vanzelfsprekend onderdeel van het kwaliteitsbeleid worden gezien dan een aanleiding voor 
een specifieke produktkwaliteitsverbetering.

Het verdient derhalve de voorkeur produktkwaliteitsverbeteringen te omschrijven in termen van marktgerichtheid, waarbij de drie factoren markt, concurrentie en interne organisatie de spil vormen. Daarbij dient men zich te realiseren dat dit niet alleen de directie aanleidingen betreft maar ook de context waarbinnen de organisatie opereert; in het bijzonder de marktgroei (respectievelijk fase in de produktlevenscyclus) speelt daarbij een belangrijke rol.

\subsection{Suggesties voor verder onderzoek}

Het onderzoek heeft aangetoond dat er meer relaties tussen acties en reacties van concurrenten ten aanzien van kwaliteitsconcurrentie zichtbaar gemaakt kunnen worden dan tot nog toe is aangenomen. Daarnaast is meer zicht op de causaliteit verkregen. Ook de PIMS-studies, op voorhand bij uitstek geschikt voor dergelijke analyses, kunnen geen informatie verschaffen over het kwaliteitsconcurrentieproces.

Dit onderzoek laat zien dat het mogelijk is om meer dan slechts de reactie-intensiteit te meten. In ons onderzoek is enig inzicht verkregen in het type reactie en het effect op het succes van een produktkwaliteitsverbetering. Onze benadering is echter stapsgewijs en partieel geweest. De verschillende relaties in het model zijn voornamelijk bivariaat getoetst en in een enkel geval is een poging gedaan om met behulp van een multivariaat model de relaties te toetsen. Schatting van het hele voorgestelde model is nu niet mogelijk geweest in verband met de gebruikte schalen, het type data (veelal nominaal) en het relatief beperkte aantal waarnemingen. Weliswaar is de uitgevoerde studie de meest uitgebreide tot nog toe op dit terrein die wij kennen; dat neemt niet weg dat voor het volledig schatten van alle relaties in het model (bijvoorbeeld door middel van een padanalyse of LISREL) meer waarnemingen noodzakelijk zijn. Een aanbeveling is dan ook om op deze weg een simultane schatting van het model te verkrijgen. Ook door middel van case-studies is het wellicht mogelijk vanuit individuele cases op inductieve wijze meer inzicht te krijgen in de relaties tussen de componenten van het model. Enerzijds kan dergelijk onderzoek relevant zijn voor toekomstige studies naar markttoetredingen, om uitspraken te kunnen doen over het type reactie. Anderzijds is het voor markt-specifiek onderzoek van belang uitspraken te kunnen doen over de generaliseerbaarheid van de gevonden relaties en rekening te houden met branche-gebonden invloedsfactoren.

Tot slot blijkt dat de service-aspecten belangrijk zijn in het kwaliteitsconcurrentieproces. Het verder ontwikkelen van methodieken om die kwaliteit meetbaar te maken en te beheersen is een belangrijke taak voor industriële ondernemingen die op zoek zijn naar concurrentiele voordelen op het gebied van kwaliteit. Ook voor het universitaire onderzoek is het van belang het voortouw te nemen bij het ontwikkelen van methoden en hulpmiddelen daarbij. Een kenmerk van service (en dienstverlening in het algemeen) is de gelijktijdige produktie en consumptie van de dienst. Dit "samen produceren" leidt ertoe dat organisatievraagstukken, op bijvoorbeeld het gebied van het personeels-management, nauw verweven zijn met marketing-vraagstukken. Vanwege het inherente multidisciplinaire karakter van dergelijk onderzoek is dat dus zeker niet aileen het domein van de marketing-wetenschap. 


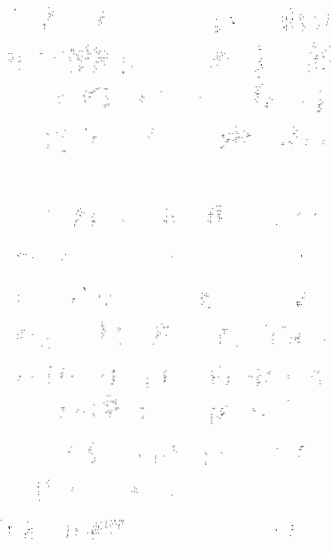




\section{Bijlage A. Definities van kwaliteit in de managementliteratuur}

\subsection{Kwaliteitszorg literatuur.}

\section{Interne kwaliteit:}

1. overeenstemming met vereisten:

het voldoen van het produkt aan de daarvoor opgestelde specificaties

Schaafsma \& Willemze (1954; p. 4-59):

"[kwaliteit is] de mate waarin bij de vervardiging van het produkt is voldaan aan de specificaties".

Gilmore $\left(1974\right.$; p. $\left.16^{99}\right)$ : "Quality is the degree to which a specific product conforms to a design or specification".

Crosby (1979; p. 15): "Quality must be defined as "conformance to requirements'" .

Luchs (1986; p. 12): Management tends to evaluate the quality of its products from an intemal perspective: does the product conform to predetermined specifications".

Goodmeasure Inc. (1988, p. 15):

"Quality means meeting standards for excellence in your product or service".

Hall $(1990$, p. 15):

"[quality] is the absence of defects; that is, the product.....performs as expected over its normal lifespan".

\section{Externe kwaliteit:}

2. gebruik:

Juran (1974; p. 2-2):

Mulder (1989; p. 14): de geschiktheid van het produkt voor gebruik door klant of consument.

"Quality is fitness for use".

"de mate warin het geheel van eigenschappen van bet produkt voldoet wan de eisen die voortvloeien uit het specifieke gebruik". de kwaliteit van de uitvoering. Zij definiëren eveneens de externe kwaliteit.

Gilmore maakt ook onderscheid tussen definitie van interne kwaliteit en externe kwaliteit. 


\section{3. behoeften en/ of wensen:}

de mate waarin aan behoeften en/of wensen van klanten of consumenten wordt voldaan.

Edwards (1968; p. 37): "Quality consists of the capacity to satisfy wants".

Gilnore (1974; p. 16): "Quality is the degree to which a specific product satisfies the wants of a specific consumer".

Van Ettinger (1974, p. 93): "..de mate wearin de eigenschappen van het produkt zijn aangepast aan de gebruikseisen, voortvloeiende uit een gegeven behoefte".

Stichting Kwaliteitsdienst (KDL; Fremery en Van Lier 1975; p. 40):

"Het geheel aan trekken en kenmerken van een voortbrengsel dat bepalend is voor het vermogen orn een gegeven behoefte te bevredigen. Kwaliteit is dan kortweg: geschiktheid woor benutting".

Mulder $(1976 ;$ p. 7$): \quad$ [kwaliteit is] het geheel vam produkteigenschappen dat van invloed is op de geschiktheid van het produkt om bepaalde gekende of geschatte behoeften te bevredigen".

Geiger (1977; p. 92): "Kwaliteit is de totaliteit van eigenschappen en kenmerken van een produkt, die gebasserd zijn op de geschiktheid daarvan voor het bevredigen van een gegeven behoefte".

Ishikawn (1985; p. 44): "QQuality which can satisfy the requirements of consumers".

KIuwer's Handboek Kwaliteitsbeleid (1987: p. 1.1.-1):

"[Onder kwaliteit wordt verstaan] het geheel van kenmerken en eigenschappen van een produkt of dienst dat bijdraagt tot het vermogen ervan om te voldoen aan een gegewen behoefte".

ISO Draft Guide (1989; p. $\left.4^{100}\right)$ :

"The totality of features and characteristics of a product or service that bear on its ability to satisfy a given need"

4. doel(en); de mate waarin produkten geschikt zijn voor bepaalde doel(en) waarvoor het produkt gebruikt wordt.

Schasfsma \& Willemre (1954; p. 4-5):

"[kwaliteit is] de mate waarin de in het ontwerp vastgestelde eigenschappen voldoen an het doel wasrvoor het produkt moet worden gebruikt, daarbij bedenkend dat bet doel de prijs omvat".

Voen (1980; p. 97): "Kwaliteit is de mate warin produkt of dienst voldoet an een gesteld doel". 
Scanlon \& Hagan (1986; p. 20):

"[kwaliteit is] de mate waarin het geheel van eigenschappen wan een produkt, proces, of dienst voldoet aan de eraan gestelde eisen, welke voortvloeien uit het gebruiksdoel".

5. verwachtingen: de mate waarin het produkt tegemoet komt aan de verwachtingen van klanten of consumenten.

Feigenbaum (1961; p. 13): "[quality is] the composite product characteristics of engineering and manufacture that determine the degree to which the product in use will meet the expectations of the consumer".

Castillo (1974; p. 109): "Kwaliteit is de verhouding tussen wat de gebruiker ontvangt en wat hij verwachtte te ontvangen".

Feigenbaum (1983; p. 7): "[Product and service quality can be defined as] the total composite product and service characteristics of marketing, engineering; manufacture, and maintenance through which the product and service in use will meet the expectations of the customer".

6. concurrentie: $\quad$ de prestaties van het produkt ten opzichte van de concurrerende produkten.

Shetty \& Buehler (1985, p. 6):

"[Quality defined as] customer's evaluation of the business product/service package as compared with that of competitors".

\subsection{Marketing literatuur.}

\section{Externe kwaliteit.}

2. gebruik:

Genth $(1981 ;$ p. 19):

Kotler (1984; p. 479): de geschiktheid van het produkt voor gebruik door klant of consument.

"Qualitāt ist diejenige Beschaffenheit, die eine Ware oder eine Dienstleistung aur Erfullung vorgegebener Fordenungen geeignet macht. Die vorgegeben Erforderungen ergeben sich im allgemeinen aus dem Verwendungszwack" .

"..the rated ability of the brand to perform its functions perceived by customers". 
3. behoeften en/of wensen;

de mate waarin aan behoeften en/of wensen van klanten of consumenten wordt voldaan.

Kuehn \&ay (1962; p.101): "In the final analysis of the marketplace, the quality of a product depends on how well it fits patterns of consumer preferences".

Colenbrander ( 1970 , p. 3033); "Kwaliteil is de mate warin een produkt zijn functie vervalt, gerelateerd aan de behoefte yan de gebruiker*.

Maynes (1976; p. 542): "Quality consists of the extent to which a specimen (a product-brand/modelseller combination) possesses the service characteristics you desire".

Box (1984; p. 179): ",the degree to which product fulfills its functions, given the needs of the consumer".

Leeflang (1987; p. 221-222): "[kwaliteit is] de mate warin de eigenschappen (attributen) van het produkt aansluiten bij de verlangens van degemen die zich in de doelgroep bevinden".

4. doel(en):

de mate waarin produkten geschikt zijn voor bepaalde doel(en) waarvoor het produkt gebruikt wordt.

Kawlath (1969; p. 50): "Eignung fur bestimmte Zwecke", en vermeldt dat de kwaliteit van een produkt uitsluitend teleologisch te begrijpen is, dus geschikt moet zijn voor bepalde doeleinden.

5. verwachtingen: de mate waarin het produkt tegemoet komt aan de verwachtingen van klanten of consumenten.

Parasuraman, Zeithaml \& Berry (1986; p. 6):

"..perceived service quality is the degree and direction of discrepancy between consumers' perceptions and expectations" *

6. concurrentie: de prestaties van het produkt ten opzichte van de concurrerende produkten.

Monroe Krishinan (1985 p. 212):

"Perceived product quality is the perceived ability of a product to provide satisfaction relative to the available alternatives". 


\section{Bijlage B. De multidimensionaliteit van het kwaliteitsbegrip en de reacties van de concurrent: micro-economische benadering}

Op basis van het in paragraaf 2.3. aangegeven eenvoudige neoklassieke model wordt nu een aanpassing beknopt uitgewerkt met zowel een multidimensioneel kwaliteitsbegrip als reacties van de concurrenten.

Stel dat er $n$ concurrenten op de markt zijn, die elk een produkt met kwaliteit $Q_{i}$ produceren, met een prijs $p_{j}$. Dezelfde uitwerking kan ook worden gegeven met andere elementen van de marketing-mix. Vanwege de eenvoud van presentatie kiezen wij bij deze afleiding voor de prijs. De afzetfunctie voor de i-de onderneming heeft dan de vorm:

$\mathbf{x}_{\mathrm{i}}=\mathrm{f}_{\mathbf{i}}\left(\mathbf{p}_{1}, \ldots, \mathbf{p}_{\mathrm{l}}, \ldots \mathbf{p}_{\mathbf{p}}, \mathrm{Q}_{1}, \ldots, \mathrm{Q}_{\mathrm{i}}, \ldots, \mathrm{Q}_{\mathrm{n}}\right)$,

waarbij:

$x_{i}=$ afzet $i-$ de onderneming,

$p_{1}=$ prijs $i$-de onderneming.

$Q_{i}=$ kwaliteit i-de onderneming,

en:

$\delta f_{,} / \delta p_{k}>0, k=1, \ldots, n$ en $k \neq i$.

$\delta f_{j} / \delta Q_{k}<0, k=1, \ldots, n$ en $k \neq i$.

$\delta \mathrm{f}_{1} / \delta \mathrm{p}_{1}<0$

$\delta \mathrm{f}_{\mathrm{i}} / \delta \mathrm{Q}_{\mathrm{i}}>0$

In plaats van kwaliteitsindices $Q_{1} t / m Q_{m}$ van de $n$ concurrenten, worden nu de kwaliteitsvectoren $\mathbf{Q}_{1}, \ldots, \mathbf{Q}_{\mathrm{n}}$ gespecificeerd, met $\mathrm{m}$ (i) kwaliteitsdimensies, om rekening te houden met het multidimensionele karakter van kwalliteit. Daarbij is

$Q_{i}=\left(Q_{i j}, \ldots, Q_{\operatorname{man}(0)}\right)$.

De kwaliteit van onderneming i kan aldus uitgedrukt worden als een vector met $\mathrm{m}(\mathrm{i})$ kwaliteitseigenschappen.

Wordt rekening gehouden met concurrentiële reacties dan kan dat tot uitdrukking worden gebracht in de termen, die de reactie met de verschillende kwaliteitseigenschappen van de verschillende concurrenten weergeeft:

$\delta Q_{k} / \delta Q_{i}, \quad k=1, \ldots \ldots, n$ en $k \neq i$.

De termen met kruiselasticiteiten geven in dit geval de reactie van de concurrenten met de prijs weer (uiteraard kunnen in plaats van, of aanvullend op de prijs ook andere marketing-mix instrumenten gespecificeerd worden):

$\delta p_{k} / \delta Q_{i}, \quad k=1, \ldots \ldots, n$ en $k \neq i$. 
Beide reactietermen komen nu voor in de specificatie van de invloed van een kwaliteitsverbetering op de afzet. De invloed van kwaliteitsverbeteringen van i op de afzet van onderneming $\mathrm{i}$ kan als volgt worden weergegeven:

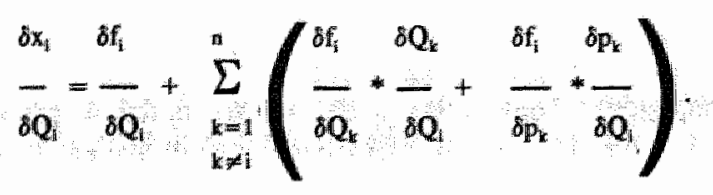

Een verbetering van de kwaliteit door onderneming $\mathrm{i}$ leidt slechts dan tot een verbetering van de afzet wanneer de reacties an de concurrenten slechts zo sterk zijn dat geldt:

$$
\underset{\delta Q_{i}}{\delta-|>|} \sum_{k=1}^{\sum} \frac{\delta f_{i}}{\delta Q_{k}} * \frac{\delta Q_{k}}{\delta Q_{i}}+\frac{\delta f_{i}}{\delta p_{k}} * \frac{\delta p_{k}}{\delta Q_{i}}
$$

Er kan nu ook een stelsel vergelijkingen opgesteld worden met de naar $p_{i}$ en $Q_{i 1} t / m Q_{\text {im(i) }}$ gedifferentieerde winstfunctie:

$W_{i}=f_{i}\left(p_{1}, \ldots, p_{i}, \ldots p_{i n}, Q_{1}, \ldots, Q_{i}, \ldots, Q_{n}\right) p_{1}-K_{i}\left(x_{i}\left(p_{i j}, Q_{i}, Q_{i j}\right)\right.$

waarbij:

$w_{1}=$ winst $i$-de onderneming,

$K_{i}=$ kosten i-de onderneming,

en:

$\delta \mathrm{K}_{i} / \delta \mathrm{p}_{1}<0$ en $\delta \mathrm{K}_{4} / \delta \mathrm{Q}_{i}>0$.

Er kan weer rekening gehouden worden met concurrentiële reacties door de kwaliteits- en prijsreacties van de concurrenten te specificeren. Het blijkt dan bijvoorbeeld in het stelsel van vergelijkingen waarbij de winst wordt gemaximaliseerd, dat eén van deze vergelijkingen, waarbij gedifferentieerd wordt naar $Q_{i 1}$, de eerste kwaliteits-eigenschap van $\mathbf{Q}_{i}$, luidt:

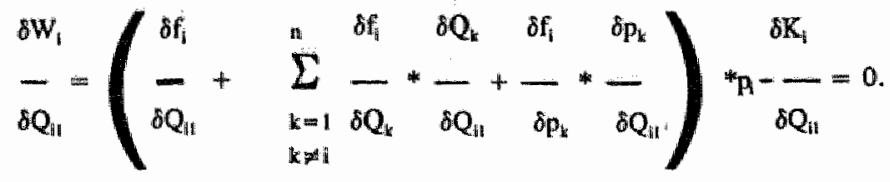

Hieruit is een conclusie te trekken ten aanzien van het kwaliteitsbeleid van onderneming $i$, waarbij rekening wordt gehouden met concurrentiële reacties. Er moet voldaan zijn aan:

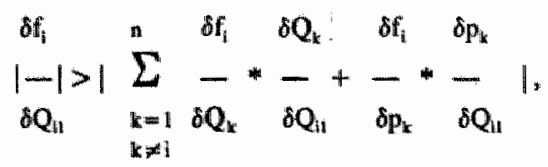

om, gegeven winstmaximering, überhaupt zinvol kwaliteitsverbeteringen aan te brengen. 
Namelijk kwaliteitsverbetering ten aanzien van cén eigenschap van goed i die moet leiden tot een verbetering van de winst van $i$, mag geen aanleiding zijn voor vergelijkbaar sterke kwaliteits- of prijsreacties van concurrenten. De positieve invloed van kwaliteitsverbeteringen op de winst kan daardoor teniet worden gedaan.

Wanneer we ons nu beperken tot de optimale kwaliteitsmix, en de concurrenten geen rol laten spelen, kunnen de volgende afleidingen worden opgesteld om iets te zeggen over de optimale mix van kwaliteitseigenschappen. Ten aanzien van het bepalen van de optimale kwaliteitsmix van kwaliteitseigenschappen geldt voor bijvoorbeeld de eigenschappen $Q_{i l}$ en $Q_{i 2}$ :

$\frac{\delta \mathrm{x}_{\mathrm{i}}{ }^{*} \mathrm{p}_{\mathrm{i}} / \delta \mathrm{Q}_{\mathrm{il}}}{\delta \mathrm{x}_{\mathrm{i}}{ }^{*} \mathrm{P}_{\mathrm{j}} / \delta \mathrm{Q}_{\mathrm{iz}}}=\frac{\delta \mathrm{K}_{\mathrm{i}} / \delta \mathrm{Q}_{\mathrm{it}}}{\delta \mathrm{K}_{\mathrm{i}} / \delta \mathrm{Q}_{\mathrm{iz}}}$

De verhouding tussen twee kwaliteitseigenschappen is optimaal, wanneer de verhouding tussen marginale opbrengsten gelijk is aan de verhouding van de marginale kosten (van de betreffende kwaliteitseigenschappen). Er kan evenzo worden afgeleid dat de optimale kwaliteitsmix tussen twee kwaliteitseigenschappen ontstaat wanneer de verhouding tussen de prijselasticiteiten gelijk is aan de verhouding tussen de kostenelasticiteiten.

$\frac{\epsilon\left(\mathrm{p}_{i}, \mathrm{Q}_{\mathrm{i}}\right)}{\epsilon\left(\mathrm{p}_{\mathrm{i}}, \mathrm{Q}_{\mathrm{i}}\right)}=\frac{\epsilon\left(\mathrm{K}_{\mathrm{i}}, \mathrm{Q}_{\mathrm{i}}\right)}{\epsilon\left(\mathrm{K}_{\mathrm{i}}, \mathrm{Q}_{\mathrm{i}}\right)}$

Samenvattend blijkt dat het succes van een PKV afhankelijk is van de sterkte van de reactie van de concurrenten. Deze reactie kan betrekking hebben op zowel kwaliteitseigenschappen als andere marketing-mix instrumenten.

Eveneens blijkt dat de kwaliteitsmix optimaal is wanneer de verhouding tussen de marginale opbrengsten en de marginale kosten tussen de eigenschappen gelijk is. Dit geldt echter alleen als de concurrentie geen rol speelt. Wordt de concurrentie in deze analyses betrokken dan spelen reactietermen van de concurrentie wel een rol bij de bepaling van de optimale kwaliteitsmix ${ }^{101}$. 


$$
\text { . }
$$




\section{Bijlage C. Verantwoording ten aanzien van de onderzoeks- opzet, de pilot-studie en de steekproef}

\section{C.1. Pilot-studie en voorbereiding definitieve onderzoek}

In de maanden januari en september/oktober 1986 is een pilot-study uitgevoerd om zicht te krijgen op de haalbaarheid van een onderzoek naar de kwaliteitsconcurrentieproblematiek in enkele branches. Bovendien was het de bedoeling een vragenlijst te testen, evenals te kunnen kiezen uit een aantal alternatieve vraagstellingen. In totaal is voor het vooronderzoek een 14-tal bedrijven benaderd in de provincies Limburg en Brabant. De bedrijven varieerden in omvang van 20 werkzame personen tot enkele duizenden werknemers.

Het resultaat van het vooronderzoek was dat het inderdaad mogelijk is een gedetailleerd beeld te krijgen van kwaliteitsverbeteringen en concurrentiële acties, maar dan voor maximaal één gebeurtenis per respondent. De definitieve vragenlijst behandelt dan ook én kwaliteitsverbetering per bedrijf. Verder bleek het niet goed mogelijk de relatieve kwaliteitspositie van de ondememing op een betrouwbare manier te meten. Om die reden is gekozen voor een kwaliteitsverbetering als uitgangspunt voor het meten van concurrentiële reacties en resultaten.

Naast vragen over kwaliteit bevatte de vragenlijst ook vragen over behandeling van klachten door ondernemingen. Deze gegevens komen in dit onderzoek verder niet aan de orde. $\mathrm{Zij}$ zijn tegelijkertijd verzameld, maar dienen andere doeleinden. Daar is elders over gerapporteerd (Lemmink 1988, Lemmink \& Kasper 1989).

Het schriftelijke onderzoek is uitgevoerd in de periode november 1987 -januari 1988 . Voor dit onderzoek zijn twee steekproefkaders gebruikt. Het ledenbestand van de Regionale Kwaliteitskringen in Nederland, als steekproefkader voor in "kwaliteit" geïnteresseerde bedrijven, en het bestand van de gezamenlijke Kamers van Koophandel in Nederland (N.V, Databank, Woerden), als representatief steekproefkader voor ondernemingen in Nederland. Er is gecorrigeerd voor bedrijven die in beide bestanden voorkwamen.

\section{C.2. Steekproefkader Regionale Kwaliteitskringen}

In het kader van de aandacht voor kwaliteitszorg door onder andere de nationale overheid en branche-organisaties zijn verschillende instituten en samenwerkingsverbanden ontstaan, met als doel door onderlinge hulp en advisering kwaliteitszorg binnen de bedrijven te stimuleren. Zo functioneren in Nederiand ook een aantal branche-onafhankelijke Regionale Kwaliteitskringen. Hierin hebben naast vertegenwoordigers van bedrijven ook veelal vertegenwoordigers van adviserende organen, zoals de Rijksnijverheidsdienst (nu Innovatiecentra), de NEHEM en de Kamers van Koophandel zitting.

In principe zijn alle leden van 11 van de 12 Regionale Kwaliteitskringen in Nederland benaderd, behalve adviesbureaus en leden, waarvan uit de tenaamstelling bleek dat het om een dienstverlenend bedrijf zou handelen. Verder kwam het voor dat een bedrijf meer dan één vertegenwoordiger had; in dat geval is cén lid geselecteerd. Het totaal aantal leden 
van Regionale Kwaliteitskringen bedroeg medio 1987: $751^{102}$. Het totaal aantal verstuurde vragenlijsten aan leden bedroeg uiteindelijk, na aftrek van de bovengenoemde "advies"-, "dienstverlenings" ${ }^{-}$, en "dubbel"-leden: 451. De verdeling over de Regionale Kwaliteitskringen was als volgt:

Tabel C.1.: Verdeling wan de benaderde bedrijwen over de regionale kwaliteitskringen.

\begin{tabular}{|c|c|c|c|c|c|c|c|c|c|c|}
\hline 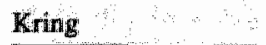 & Bruto & & $\therefore$ & Aantal & I benaderde leden & 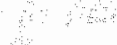 & & & & \\
\hline Noord Mederland & 83 & & & 55 & 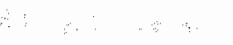 & & & & $\because$ & \\
\hline Noord Flolland & 47 & & & 24 & $\cdots \quad:$ & $\cdots$ & & & & \\
\hline Twente & 98 & & & 59 & & & & & & \\
\hline Arnhem & 31 & & & 19 & & & & & & \\
\hline Zuid Hollland & 134 & & & 56 & & & & & & \\
\hline Zeeland & 23 & & & 16 & & & & & & \\
\hline Breda & 89 & & & 62 & & & & & & \\
\hline Helmond & 61 & & & 41 & $\therefore \quad:$ & & & & & \\
\hline Noord-Oost Brabant & 89 & & & 62 & & & & & & \\
\hline Noord Limburg & 35 & & & 20 & & & & & & \\
\hline Zuid Limbuirg & 61 & & & 37 & & & & & & \\
\hline Totaal & 751 & & & 451 & & & & & & \\
\hline
\end{tabular}

\section{C.3. Steekproefkader N.V. Databank}

Het inschrijvingenregister van de N.V. Databank is gebruikt om een representatieve steekproef samen te stellen uit een aantal branches in Nederland.

De N.V. Databank beschikt over ongeveer 600.000 inschrijvingen in het Handelsregister (N.V. Databank 1987). Deze inschrijving is voor de meeste typen ondernemingen verplicht, zodat ze een redelijk compleet beeld geeft van de het Nederlandse bedrijfsleven. Naast adresgegevens wordt nog een aantal gegevens geregistreerd, zoals de branche, waarbinnen het bedrijf opereert, weergegeven door een activiteitencode (SBIindeling ${ }^{103}$ ), en de grootte van de onderneming in werkzame personen (personeelsomvang).

Voor het onderzoek is een aantal bedrijven geselecteerd uit branches, die ook veelvuldig vertegenwoordigd zijn in Regionale Kwaliteitskringen. Een ander criterium voor selectie was het aantal werkzame personen. Bedrijven met meer dan 10 werkzame personen zijn geselecteerd, om verzekerd te zijn van organisaties van enige omvang.

In het totaal zijn 1437 bedrijven benaderd uit het bestand van de Kamers van Koophandel. Door deze wijze van classificeren (namelijk sterk gericht op het produktieproces) van de Kamers van Koophandel is het mogelijk dat sommige ondernemingen niet direct te selecteren zijn uit de meest voor de hand liggende activiteitencode. Derhalve is ter completering van deze branches, deze selectie aangevuld met bedrijven, verkregen uit

Exclusief de Regionale Kwaliteitskring Midden Nederland, waarvan geen adresinformatie is ontvangen. 
adresinformatie van branche-organisaties ${ }^{104}$. In totaal leverde dit 71 extra adressen op. De verdeling over de verschillende branches was als volgt:

Tabel C.2.: Verdeling van de populatie en steekproef over de benaderde branches.

\begin{tabular}{|c|c|c|c|c|c|}
\hline SBI: & Branche & Steekproef & Fractie & Extra & \\
\hline $2081 / 2082$ & Vaedings- en genotmiddelen: & & & & \\
\hline $2084 / 2171$ & *Brood, beschuit en banket & 194 & $1: 1$ & 18 & \\
\hline \multirow[t]{2}{*}{$2172 / 2179$} & *Sigaretten en tabak & 23 & $1: 1$ & 4 & \\
\hline & *Overige voeding/genot & 274 & $1: 3$ & & \\
\hline $225 / 226$ & Tapijt, vloermatten, linoleum & 40 & $1: 1$ & 8 & \\
\hline 2951 & Verf-, lak-, en vernis & $=$ & $1: 1$ & & \\
\hline 2972 & Parfumerie-, en cosmetica & 26 & 1:1 & 41 & \\
\hline 311 & Rubberverwerking & 13 & $1: 3$ & & \\
\hline 313 & Kunststofverwerking & 101 & $1: 3$ & & \\
\hline 33 & Basismetaal & 81 & $1: 1$ & & \\
\hline 3485 & Huishoudelijke apparaten & 26 & 1:1 & & \\
\hline 35 & Machines & 393 & $1: 3$ & & \\
\hline 36 & Electrotechniek & 126 & $1: 3$ & & \\
\hline \multirow[t]{2}{*}{$381 / 382 / 384$} & Instrumenten en optiek & $\underline{156}$ & $1: 1$ & & \\
\hline & Totaal & $1 \overline{509}$ & & $\overline{7} 1$ & \\
\hline
\end{tabular}

Vanwege de dubbeltellingen met het steekproefkader van de Regionale Kwaliteitskringen is een correctie aangebracht. Het aantal dubbeltellingen bedroeg 72 . In mindering gebracht op de 1509 adressen leverde dit 1437 adressen op. Aangevuld met 71 "branche"adressen resulteerde uiteindelijk een bestand met 1508 adressen, die ook daadwerkelijk zijn benaderd.

\section{C.4. Verloop van het veldonderzoek}

De totale steekproef bestond dus uit 1508 (N.V. Databank) +451 (Regionale Kwaliteitskringen) $=1959$ ondernemingen .

Begin november 1987 zjjn de vragenlijsten verstuurd. Vervolgens is in de eerste week van december een reminder verstuurd naar alle bedrijven die nog niet hadden gereageerd. Tenslotte is 18 december 1987 een tweede reminder gestuurd, met daaraan gekoppeld een "non-respons" vragenformulier. Op 29 januari 1988 is de inzendtermijn gesloten. Daarna

Het betrof de brancheverenigimgen Stichting Sigarettenindustrie (4 adressen) , VERBISKO (Vereniging van Fabrikanten wan Banket, Biscuilt, Koek en aanverwante produkten; 18 adressen), VNTF (Vereniging van Nederlandse Tapijtfabrikanten; 8 adressen) en de Nederlandse Cosmeticavereniging (41 adressen). Voor de cosmetica-industrie betrof het vooral de vertegenwoordigers van buitenlandse ondernemingen en handelsbedrijven. De N.V. Databank beschikt over bedrijfskenmerken als werkzame personen, branche (aktiviteitencode; SBI), geografische ligging, rechtsvorm e.d.. Voor zover de adressen niet afkomstig waren van de N.V. Databank (met name de adressen van de Regionale Kwaliteitskringen en vam branche organisaties), is mafloop zoveel mogelijk de betreffende Databank-informatie toegevoegd. Indien dit niet mogelijk bleek te zijn is de betreffende informatie verkregen uit de "ABC-gidis voor de handell en industrie" ( $A B C$ voor handel en industrie, Haarlem) en de "Kompass-gids" (Kompass Nederland B. V., Amsterdam). 
zijn geen vragenformulieren meer ontvangen.

Gedurende het onderzoek zijn nim 100 telefonische vragen binnengekomen over het onderzoek of mededelingen van niet-deelname.

$\mathrm{Na}$ afloop van het onderzoek is ultimo mei 1988 an de respondenten die hebben meegewerkt een samenvatting van de uitkomsten verstrekt. Hierin was de positie van de eigen onderneming af te lezen ten opzichte van het gemiddelde van bedrijven uit dezelfde branche voor een aantal kernvariabelen. Met het sturen van deze beloofde informatie werd het veldwerk afgesloten.

Tabel C.3n: Chronologische volgorde van de veldwerkaktiviteiten.

12 november 1987: wersturen van de vragenlijsten.

2 december 1987: vershuren van de eerste reminder.

18. december 1987: versturen van de tweede reminder en het vragenformulier voor de "non-respons".

29 januari 1988: afsluiting van de inzendtermijn.

20 mei 1988: versturen van de belangrijkste uitkornsten van het eigen bedrijf en dezelfde uittkomsten per branche om vergelijkingen mogelijk te maken

\section{C.5. Respons en non-respons}

In totaal is er door 666 bedrijven gereageerd op het vragenformulier. Dit gebeurde voor een deel met een telefonisch of schriftelijk bericht van niet-deelname ( 282 bedrijven, waar onder de 193 ondernemingen die het non-respons formulier hebben ingevuld), en voor een ander deel door invulling van het vragenformulier (384 bedrijven). De gegevens van de bedrijven die niet hebben meegewerkt kunnen bijdragen tot de beoordeling van de representativiteit van de steekproef. Door vergelijkingen te maken kan hiervan een inschatting worden gemaakt. Onder non-respons wordt hier verstaan de ondernemingen die wel hebben gereageerd, maar niet het vragenformulier hebben ingevuld. De hier genoemde non-respons van 282 bedrijven kan dan representatief geacht worden voor de ondernemingen die niet hebben gereageerd.

De totale bruto-respons ${ }^{105}$ bedraagt $384+282=666(=34 \%)$, de totale nettorespons ${ }^{106} 384(=20 \%)$. De respons van de leden van de Regionale Kwaliteitskringen is aanmerkelijk hoger. Mogelijke oorzaken voor dit verschil is het feit dat de vragenlijst naar kwaliteitskringleden op naam werd verzonden, en dat deze leden waarschijnlijk meer geînteresseerd zijn in het onderwerp.

Er is, samen met de tweede reminder, aan 613 ondememingen die tot dan nog niet hadden gereageerd een "non-respons" vragenformulier uitgereikt. In totaal 193 (=31\%) bedrijven hebben dat vragenformulier ingevuld. In totaal hebben verder 89 respondenten, hetzij telefonisch, hetzij schriftelijk melding gemaakt van het niet deelnemen (zie ook tabel C.5).

Aantal bedrijven dat het vragenformulier heeft ingevuld. 


\begin{tabular}{|c|c|c|c|c|}
\hline & $\begin{array}{l}\text { Verstuurde } \\
\text { formulieren }\end{array}$ & 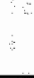 & Respons & Non-Respons \\
\hline Bedrijven Regionale Kwralliteitskringen & 448 & & $173(39 \%)$ & $93(21 \%)$ \\
\hline Bedrijven Kamer van Koophandel & $\underline{1491}$ & & $200\left(13 x^{2}\right)$ & $147(105)$ \\
\hline Totaall werstuurd ${ }^{\text {vor }}$ & $\overline{1939}$ & & $373(199)$ & $240(12 \%)$ \\
\hline $\begin{array}{l}\text { Onbekende oorsprong door } \\
\text { ontbreken van identificatie: }\end{array}$ & 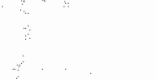 & & 11 & $\underline{42}$ \\
\hline Totaal & & & $384(20 \%)$ & $282(14 \%)$ \\
\hline
\end{tabular}

Tabel C.5.: De wijze warop de bedrijven hebben gereageerd, die niet het vragenformulier hebben ingevuld.

\begin{tabular}{lclll} 
Wijze van reageren & Totaal & Spontaan & "Non-respons"-formulier \\
\hline Schriftelijk & 246 & 53 & 193 \\
Telefonisch & $\underline{36}$ & $\frac{36}{89}$ & $\frac{1}{193}$ \\
Totasl & 282 & 89 & \\
\hline
\end{tabular}

Een groot aantal bedrijven (262) heeft aangegeven welke redenen men had om niet deel te nemen aan het onderzoek. Tabel C.6. geeft een overzicht van de redenen. De meest genoemde reden was, volgens verwachting (zie ook Kasper 1982), het gebrek aan tijd, gevolgd door de opmerking dat de vragenlijst meer toegesneden was op fysieke produkten dan op dienstverlening. Dit is inderdaad een feit, en wij hebben getracht te voorkomen dat grote aantallen dienstverlenende bedrijven de vragenlijst toegestuurd zouden krijgen. Een probleem bleek echter te zijn om dienstverlenende "metaal"-bedrijven, met naast enige produktie vooral bouw- en installatiewerk van machines, wit te selecteren. In feite is echter bij verdere bestudering van de vragenlijst door de respondent het wel mogelijk de vragen te beantwoorden voor een dienstverlenend bedrijf. Verder werd genoemd dat het onderzoek niet interessant genoeg of te moeilijk was, o.a. vanwege de speciale relaties met de moedermaatschappij. In een klein aantal gevallen was er sprake van sluiting of fusie van het aangeschreven bedrijf. In enkele gevallen vond men de vertrouwelijkheid van de gegevens niet afdoende gewaarborgd.

De respons kan ook beïnloed zijn door recente mutaties van het Databank-bestand door verhuizingen, faillisementen e.d. Van 20 bedrijven is een duidelijk signaal voor handlen, omdat bezorging van de vragenlijst door de PTT niet mogelijk was. 
Te weinig tijd voor invullen

Meer dienstyerlening dan produktie

Niet interessiant genoeg.

Vragenlijst moeilijk in te villen

Ons bedrijf is te klein

Moeilijk; vanwege band met moederbedriff

Vertrouwelijkheid van de gegevens

Sluiting, fusie, lege BV

Andere reden
$(34,0 \%)$

$(16,0 \%)$

Om de "non-respons" te vergelijken met de respons is het zinvol de antwoorden op een aantal kernvragen met elkaar te vergelijken. Eerst is gekeken of de omvang van de bedrijven tussen de twee groepen verschilde, en vervolgens of er verschil bestond tussen de twee groepen ten aanzien van het aantal doorgevoerde kwaliteitsverbeteringen in de periode 1983-1987 $7^{109}$. De resultaten geven geen significante verschillen ( $\chi^{2}$-toets; p $>0,05)$ ten aanzien van deze kenmerken te zien. Zie voor deze resultaten tabel C.7. en C.8..

Tabel $C_{n}$ 7.: Verschillen in omvang (werkzame personen) tussen de respons bedrijuen en de "nonrespons" bedrijven.

\begin{tabular}{lcl}
\hline Werkzame personen & Respons & "Non-respons" \\
\hline Minder dan 10 & $23(7,4 \%)$ & $13(7,5 \%)$ \\
$10-49$ & $144(46,3 \%)$ & $87(50,0 \%)$ \\
$50-99$ & $53(17,0 \%)$ & $27(15,5 \%)$ \\
$100-199$ & $32(10,3 \%)$ & $27(15,5 \%)$ \\
$200-499$ & $43(13,8 \%)$ & $10(5,7 \%)$ \\
500 of meer & $16(5,1 \%)$ & $10(5,7 \%)$ \\
Totaal & $311(100 \%)$ & $174(100 \%)$ \\
Onbekend & $\underline{73}$ & $\underline{108}$ \\
Totaal incl. Ombekend & 384 & 282 \\
\hline
\end{tabular}

Basis is 262 bedrijiven. Bij de verwerking van deze vraag is er rekening mee gehouden dat respondenten meer dan tên reden kunnen hebben. De percentages geven het andeel van de bedrijuen aan dat de betreffende reden opvoert.

Zoalls eerder vermeld, werd het onderzoek tegelijk uitgevoerd met een onderzoek naar klachtenbehandeling van bedrijven. Daarbij werd de vraag gesteld "Worden klachten op sen of andere wijze geregistreerd?". Bij de respons antwoordde $76,6 \%$ van de bedrijven bewestigend, en bij de "non-respons"-groep $80,6 \%$. Het verschijnsel dat een groter percentage van de bedrijven, die niet aan het onderzoek deelnemen klachten registreert komt ook voor in een vergelijkbasar onderzoek naar klachten van Kasper (1982). Het verschil is in ons onderzoek chter niet statistisch significant $\left(\chi^{2}\right.$-toets, $\left.p>0,05\right)$. 
Tabel C.8.: Aantal produkticwaliteitsverbeteringen, in de periode 1983-1987:

\begin{tabular}{llc} 
& Respons & Non-respons \\
\hline Geen enkele keer & $39(10,8 \%)$ & $9(5,9 \%)$ \\
$1-2$ keer & $51(14,1 \%)$ & $25(16,3 \%)$ \\
$3-4$ keer & $73(20,2 \%)$ & $23(15,0 \%)$ \\
$5-6$ keer & $49(13,5 \%)$ & $20(13,1 \%)$ \\
$7-10$ keer & $33(9,1 \%)$ & $11(7,2 \%)$ \\
$11-20$ keer & $20(5,5 \%)$ & $8(5,2 \%)$ \\
Meer dan 20 keer/continu & $97(26,8 \%)$ & $\underline{57}(37,3 \%)$ \\
Totaal & $362(100 \%)$ & $153(100 \%)$ \\
Onbekend & $\underline{22}$ & $\underline{40}$ \\
Totaal incl. onbekend & 384 & 193 \\
\hline
\end{tabular}



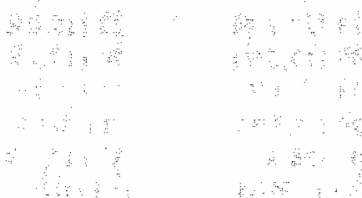

$\therefore \quad \cdots$

$\therefore \quad=$

$\therefore, \quad \cdots$ 


\section{Bijlage D. Vragenlijsten}

D.1. Vragenlijst voor het onderzoek (modelvariabelen).

\section{Produkt}

1) Het is mogelijk dat uw bedrijf niet 66 , mar een antal produkten/diensten heeft. Wak is woor uw bedrijf de belangrijkste categorie produkten of het belangrijkste produkt?

\section{Markt}

2) Hoe groot is voor uw belangrijkste produkt naar uw schatting de omzet in de totale markt? M.a.w. Wat is de omzet van u en uw concurrenten samen.

In 1986: ; Schatting in miljoenen guldens.

Wilt $u$ een schatting geven van uw marktandoel (als percentage van de in de vorige vrang angegeven omret).

Ons marktaandeel is ongeveer: Procent.

Kunt $\mathbf{u}$ hier moeilijk een schatting van maken, bent $u$ dan in deze markt:

0 een klein bedrijf (tot $5 \%)$.

0 een middelgroot bedrijf (5-25\%).

0 een groot bedrijf ( $25 \%$ en meer).

3) Hoe groot is naar uw mening het aantal ondernemingen in de door u afgebakende markt, waarmee u dagdwerkelijk concurreert?

Aartal ondememingen:

4) Dewe vraag gagl over de fasen in de levenscyclus van bet produkt. Hoo will w de fase in do ontwikkeling van de produktcategorie of type produkt van de ondememing omschrijven, op dit moment?

O Introduktiefase: De primaire vrang naar bet produkt begint juist toe to nemen, de produkten of diensten zijn nog steeds onbekend voor veel potentiëla gebruikers.

O Groeifase: De waag groeit met $10 \%$ of meer per jaar (reed). De technologie en/of de concurrentiestructuur verandert nog steeds.

o Verzadigingsfase: Produkten of diensten zijin bekend voor een grote meenderheid van potentiêle gebruikers. De technologie en de concurrentiestructuur is redelijk stabiel.

O Teraggangsfase: Produkten worden gezien als handelsartikel; mindler sterke concurrenten treden vit de markt. 
5) Is bet gebruikelijk in urw bedriffstak om het produkt, of een deel van het produkt regelmatig te veranderen/aan te passen?

O nee

O ja

6) Hoe vaak heeft u in de afgelopen 5 jaar kwaliteitsverbeteringen aangebracht an ww belangrijkste produkt?

O geen enkele keer

0 cen of twee keer

0 drie of vier keer

O vijf of zes keer

O zeven tot en met tien keer

0 elf tot en met twintig keer

0 meer dan twintig keer.

\section{Onderneming}

7) In 1986 bedroeg de totale omzet (exclusief BTW) in miljoenen guldens:

O minder dan 1 miljoen

O 1-2,5 miljoen

O 2,5-5 miljoen

o $5-7,5$ miljoen

o 7,5-10 miljoen

o 10-20 miljoen

O 20-30 miljoen

o $30-50$ miljoen

o $50-75$ miljoen

O 75-100 miljoen

0 meer dan 100 miljoen.

8) Het netto bedrijfsresultat: Voor NV's en BV's geldt netto bedrij.fsresultaat na aftrek van kosten en afschrijvingen en voor aftrek van vennootschapsbelasting. Voor de overige ondernemingen geldt: netto bedrijfsresultaat na aftrek van kosten, afschrijvingen en gewasrdeerd ondernemersinkomen, en voor aftrek van belastingen.

In 1986 was het netto bedrijf foresultaat:

O negatief

O positief 


\section{Marketing-strategie}

9) Er zijn verschillende centrale thema's denkbaar in uw marketingbeleid voor uw belangrijkste produkt. Wat zijn voor u de meest belangrijke thema's met betrekking tot het marketingbeleid? U. heeft daarbij 100 punten te verdelen over de genoemde zeven onderwerpen, Wilt a aan hat minst belangrijke onderwerp de minste punten geven en asn het meest belangrijke onderwerp de meste punten.

Concurrerende prijzen

Goede serviceverlening

Kwalitatief goed produkt

Afstemming op beperkte groep afnemers

De concurrent een stapje voor zijn

Marktaandeel vergroten

Nog anders, $\mathbf{n l}$.

Totall

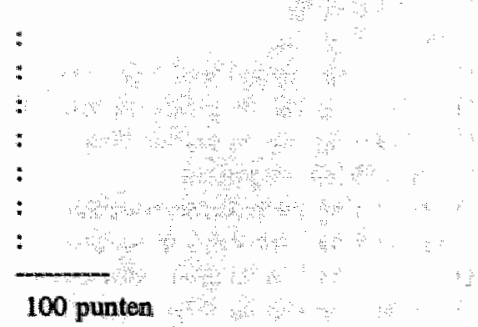

\section{Produktkwaliteitsverbetering}

10) Wilt u angeven welke de belangrijkste kwaliteitsverbetering is geweest ten aanzien van uw belangrijkste produkt, de afgelopen 5 jaar?

11) Naar aanleiding waarvan heeft in de kwaliteitswerbetering doorgevoerd? (meerdere antwoorden zijn mogelijk)

0 wensen van afnemers

O wensen van gebruikers

0 technische mogelijkheden

O kwaliteitsverbetering van concurrenten

$O$ andere acties van concurrerende ondernemingen, zoals prijswerlagingen

$O$ beschikbaarheid van kapitaal

$O$ veranderingen in de organisatie (bijv: reorganisatie)

$O$ ontevredenheid van afnemers

0 ontevredenheid van gebruikers

0 regelingen van overheidsinstanties

0 regelingen van consumenteninstanties.

O ganpassing aan certificatie-eisen (bijv. AQAP, KEMA, KOMO)

$O$ andere analeiding, namelijk 
12) Uitgaande van de kwaliteitsverbetering, genoemd onder 10), wilt a hier angeven hoe uw belangrijkste concurrent hierop gereageerd heeft? Wilt $u$ het ook angeven als de concurrent helemail niet heeft gerreageerd.

Reactie van concurrent. (meerdere antwoonden zijo mogelijk):

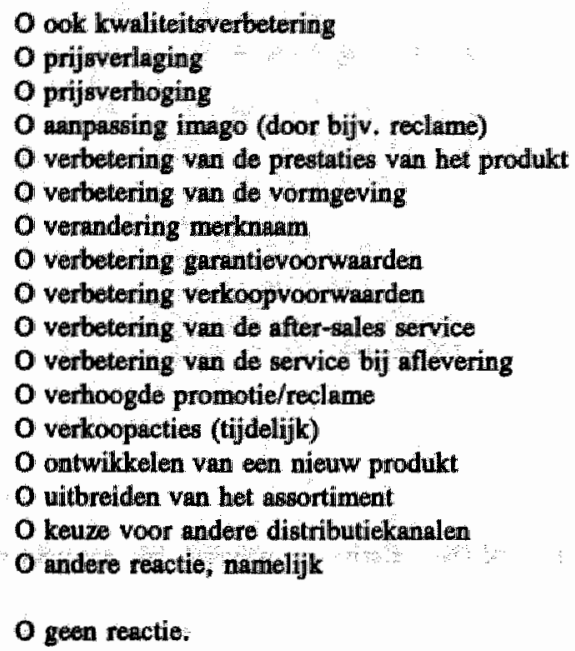

13) Indien sprake is geweest van enige worm van reactie: Hoe lang heeft het geduurd voordat deze concurrent voor het eerst daadwerkelijk reageerde met een feitelijke verandering in zijn beleid? (in masanden).

\section{Resultaat van de PKV}

14) Wilt u een schatting geven van het effect dat deze kwaliteitsverbetering(en) tot nog toe volgens uw mening heeft gehad?
A. voor het marktaindeel:
0 ists lager
O gelijkblijvend
0 iets hoger
0 beduidend hoger
B. voor het netto resultaat van de onderneming:
O geen merkbare verbetering
0 merkbare verbetering. 
D.2. Relevante vraag uit vragenlijst non-respons onderzoek (vergelijkbaar met vraag 6).

1) Hoe vaak heeft $\mathbf{u}$ in de afgelopen 5 jar kwaliteitsverbeteringen aangebracht asn uw belangrijkste produkt?
O geen enkele keer
O cho of twee keer
$O$ drie of vier keer
$O$ vijf of zes keer
O zeven tot en met tien keer
$O$ elf tot en met wintig keer
$O$ meer dan twintig keer. 


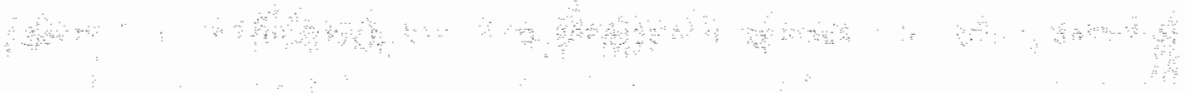

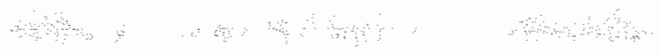
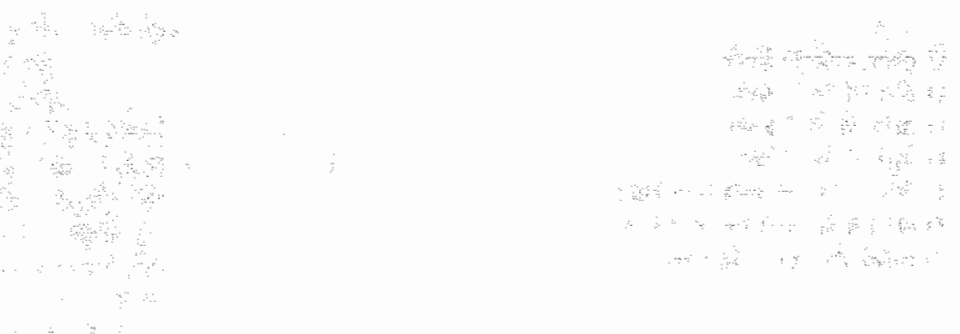


\section{Bijlage E. Profiel van de respondenten in het empirisch onder- zoek}

In deze bijlage zullen de profielen worden weergegeven van de totale groep respondenten ( $\mathrm{n}=384$ ) en de twee produkt/markt combinaties industriële markt/duurzame goederen (IDgroep) en de restgroep, bestaande uit overwegend de consumentenmarkt en niet-duurzame goederen, inclusief dienstverlening (CND-groep). De resultaten betreffen kenmerken uit het model van de markt, de marketing-strategie en kenmerken van de onderneming zelf. Daarnaast wordt het aantal PKV'n in de periode 1983-1987 besproken en volgt een vergelijking van de accenten van de marketing-strategieën tussen de verschillende fasen van de produktlevenscyclus. Als basis voor de profielen dient het aantal ondernemingen in de totale groep, de ID-groep en CND-groep, met respectievelijk 384,237 en 147 respondenten. Als bij een kenmerk het totaal afwijkt van de voornoemde totalen, houdt dat in dat de betreffende vraag door éen of een aantal onderneming(en) niet is beantwoord.

Tabel E.1.:

Resultaten voor de kenmerken uit het model.

\begin{tabular}{|c|c|c|c|}
\hline Kenmerken & Totaal & ID-groep & CND-groep \\
\hline Markt: & & & \\
\hline Marktaandeel $1^{110}$ ? & & 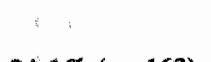 & \\
\hline $\begin{array}{l}\text { Gemiddeld: } \\
\text { Categorie: }\end{array}$ & $21,3 \%(n=259)$ & $24,1 \%(n=163)$ & $16,5 \%(n=96)$ \\
\hline $\begin{array}{l}<5 \%: \\
5-25 \%: \\
\geq 25 \%\end{array}$ & $\begin{array}{l}104(28,1 \%) \\
162(43,8 \%) \\
104(27,1 \%)\end{array}$ & $\begin{array}{l}56(24,6 \%) \\
98(43,0 \%) \\
74(32,5 \%)\end{array}$ & $\begin{array}{l}48(33,8 \%) \\
64(45,1 \%) \\
30(21,1 \%)\end{array}$ \\
\hline Totaal: & 370 & 228 & 142 \\
\hline $\begin{array}{l}\text { Aantal concurrenten? } \\
\text { Gemiddeld: } \\
\text { Categorie: }\end{array}$ & $47(n=358)$ & $34(n=218)$ & $67(n=140)$ \\
\hline $\begin{array}{l}<11: \\
11-25: \\
>25\end{array}$ & $\begin{array}{r}242(67,6 \%) \\
63(17,6 \%) \\
53(14,8 \%)\end{array}$ & $\begin{array}{c}151(69,3 \%) \\
42(19,3 \%) \\
25(11,4 \%)\end{array}$ & $\begin{array}{l}91(65,0 \%) \\
21(15,0 \%) \\
28(20,0 \%)\end{array}$ \\
\hline Totaal: & 358 & 218 & 140 \\
\hline
\end{tabular}

[vervolg volgende pagina] 110 Als het voor de respondent moeilijk was om sen schatting te maken werd gevraagd aan to gewen
in welke categorie het marktaandeel gevonden kan worden $(<5 \%, 5-25 \%, \geq 25 \%)$ 
[wervolg]

Fase in de produkt-

levenseycliss?

Introductie:

Groei:

$10(2,9 \%)$

$104(30,2 \%)$

$5(2,4 \%)$

$5(3,8 \%)$

Verzadiging:

$203(59,0 \%)$

$65(30,8 \%)$

$39(29,3 \%)$

Teruggang:

$27(7,8 \%)$

$127(60 ; 2 \%)$

Totaal:

344

$14(6,6 \%)$

$13(9,8 \%)$

211

133

Gebruikelijk in branche om regelmatig produkt te veranderen?

Ja:

$232(61,4 \%)$

152 $(64,4 \%)$

$80(56,3 \%)$

Totaal:

378

236

142

\section{Marketing-strategie:}

Accenten marketing-

strattegie?

Kwaliteit:

Service:

Prijs:

Markttaandeel:

Innovatiever:

Marktnis:

Anders:

Totanl:

\begin{tabular}{lll}
32,6 & 32,8 & 32,4 \\
20,6 & 20,3 & 20,9 \\
17,6 & 18,6 & 16,0 \\
10,6 & 9,4 & 12,6 \\
9,8 & 9,7 & 10,1 \\
6,6 & 7,1 & 5,9 \\
2,2 & 2,2 & 2,1 \\
\hline $100(\mathrm{n}=321)$ & $100(\mathrm{n}=199)$ & $100(\mathrm{n}=122)$
\end{tabular}

Ondernerning:

Totale omzet

(1986;in mln guldens)?

$<10 \mathrm{mln}$ :

$140(37,5 \%)$

$90(38,8 \%)$

$110(47,4 \%)$

$50(35,5 \%)$

$173(46,4 \%)$

$32(13,8 \%)$

$63(44,7 \%)$

$>100 \mathrm{~min}$ :

$60(16,1 \%)$

232

$28(19,9 \%)$

Totaal:

373

141

Netto bedrijfs-

resultant (1986)?

Positief:

$319(86,9 \%)$

$203(87,9 \%)$

$116(85,3 \%)$

Totaal:

367

231

136 


\section{Totaal}

Aantal PKV"n:

Géén:

1-2 keer:

3-4 keer:

5-6 keer:

7-10 keer:

11-20 keer:

$>20$ keer/continu:

Totaal:

Tabel E.3.a.:

Accenten binnen de marketing-strategie in de verschillende fasen wan de produkt levenscyclus (total over alle produkt/marktcombinaties; $n=321^{111}$ ).

\section{Strategie-}

accent:

Fase in de produlktlevenscyclus:

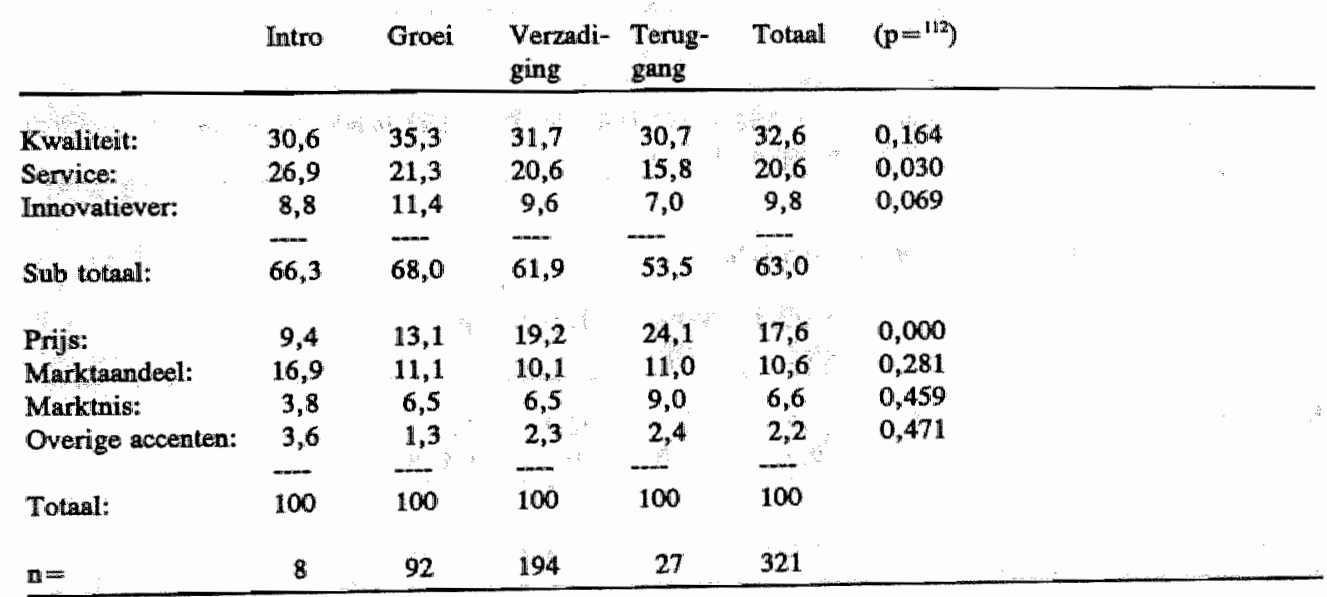

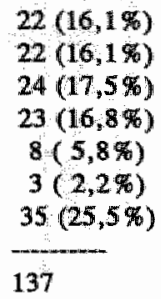


Tabel E.3.b.: Accenten binnen de marketing-strategie in de verschillende fasen van de produkt leveriscychlus (ID-groep;n=19913).

Strategie-

accent:

Fase in de produkt leveniscyclus:

Intro Groel Verzadi- Terug- Total $p=$

ging gang

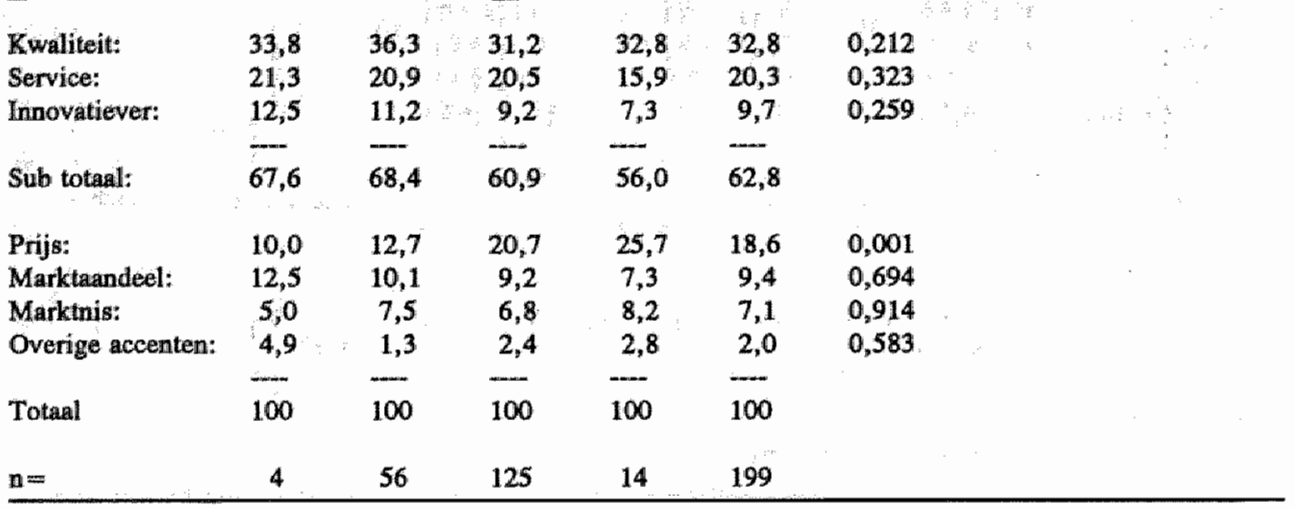

Tabel E.3.c.: Accenten binnen de marketing-strategie in de verschillende fasen van de produkt levenscyclus (CND-groep; $n=122^{14}$ ),

Strategie-

accent:

Fase in de produktlevenscyclus:

\begin{tabular}{|c|c|c|c|c|c|c|c|}
\hline & Intro & Groei & $\begin{array}{l}\text { Verzadi- } \\
\text { ging }\end{array}$ & $\begin{array}{l}\text { Terug- } \\
\text { gang }\end{array}$ & Totaal & $p=:$ & . \\
\hline Kwalliteit: & 27,5 & 33,8 & 32,6 & 28,5 & 32,4 & 0,431 & \\
\hline Service: & 32,5 & 21,8 & 20,8 & 15,8 & 20,9 & 0,098 & \\
\hline \multirow[t]{2}{*}{ Inmovatiever: } & 5,0 & 11,7 & 10,2 & 6,8 & 10,1 & 0,129 & \\
\hline & -- & $-\infty$ & - & $-\infty$ & $-\infty$ & & \\
\hline Sub totalal: & 65,0 & 67,3 & 63,6 & 51,1 & 63,4 & & \\
\hline Prije: & 8,8 & 13,7 & 16,4 & 22,3 & 16,0 & 0,190 & \\
\hline Markttaandeell: & 21,3 & 12,7 & 11,6 & 15,0 & 12,6 & 0,306 & \\
\hline Marktnis: & 2,5 & 5,0 & 5,8 & 9,8 & 5,9 & 0,208 & \\
\hline \multirow[t]{2}{*}{ Overige accenten: } & 2,4 & 13 & 1,6 & 1,8 & 2,1 & 0,816 & \\
\hline & - & $\cdots$ & $-\cdots$ & - & -- & & \\
\hline Totanal & 100 & 100 & 100 & 100 & $\mathbb{1 0 0}$ & & \\
\hline $\mathrm{n}=$ & 4 & 36 & 69 & 13 & 122 & & \\
\hline
\end{tabular}

113199 van de 237 ondernemingen beantwoordden beide vragen.

414 122 van de 147 , ondernemingen beantwoordden beide vragen. 


\section{Bijlage F. Resultaten van het empirisch onderzoek}

In deze bijlage zullen achtereenvolgens de resultaten worden weergegeven van de aanleidingen om de produktkwaliteit te verbeteren, de soorten $\mathrm{PKV} n$, de reactie van de concurrent en het gepercipieerde resultaat alls gevolg van de PKV. Daarbif wordt onderscheid gemaakt tussen het totaal, de ID- en de CND-markt. Als basis voor de vergelijking dient het aantal ondernemingen dat een omschrijving heeft gegeven van een PKV, zodat voor het totaal, de ID-groep en de CND-groep de uitkomsten zijn gebaseerd op respectievelijk 317, 206 en 111 ondememingen. Als bij een resultaat het totaal afwijkt van de voomoemde totalen, houdt dat in dat de betreffende vraag door eén of een aantal onderneming(en) niet is beantwoord.

Tabel F.1.: Aanleidingen voor het aanbrengen van PKV'n (Percentage van de ondernemingen dat een PKV heeft doorgevoerd).

\begin{tabular}{|c|c|c|c|}
\hline Aanleidingen & Totaal & ID-groep & CND-groep \\
\hline Markt-"pull": & $253(80,6 \%)$ & $165(80,5 \%)$ & $88(80,7 \%)$ \\
\hline -klantenwensen & $169(53,8 \%)$ & $111(54,1 \%)$ & $58(53,2 \%)$ \\
\hline -gebruilkerswensen & $130(41,4 \%)$ & $88(42,9 \%)$ & $42(38,5 \%)$ \\
\hline - klanten-ontevredenheid & $57(18,2 \%)$ & $41(20,0 \%)$ & $16(14,7 \%)$ \\
\hline $\begin{array}{l}\text {-gebruikers-ontevreden- } \\
\text { heid }\end{array}$ & $39(12,4 \%)$ & $27(13,2 \%)$ & $12(11,0 \%)$ \\
\hline Organisatie- & 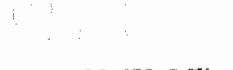 & & \\
\hline "push": & $188(59,9 \%)$ & $124(60,5 \%)$ & $64(58,7 \%)$ \\
\hline $\begin{array}{l}\text { technische } \\
\text { mogelijkheden }\end{array}$ & $166(52,9 \%)$ & $110(53,7 \%)$ & $56(51,4 \%)$ \\
\hline $\begin{array}{l}\text {-beschilkbaarheid } \\
\text { kapitaal }\end{array}$ & 7 & & \\
\hline $\begin{array}{l}\text { kapitanl } \\
\text {-verandering }\end{array}$ & $19(6,1 \%)$ & $12(5,9 \%)$ & $7(6,4 \%)$ \\
\hline organisatie & $41(13,1 \%)$ & $26(12,7 \%)$ & $15(13,8 \%)$ \\
\hline Concurrentie: & $123(39,2 \%)$ & $80(39,0 \%)$ & $43(39,4 \%)$ \\
\hline -kwaliteitswerbetering & $92(29,3,5)$ & $64(31,2 \%)$ & $28(25,7 \%)$ \\
\hline -andere actie & $43(13,7 \%)$ & $25(12,2 \%)$ & $18(16,5 \%)$ \\
\hline Derden: & $63(20,1 \%)$ & $47(22,9 \%)$ & $16(14,7 \%)$ \\
\hline -overheidsmatregelen & $35(11,1 \%)$ & $25(12,2 \%)$ & $10(9,2 \%)$ \\
\hline consumentenbond & $8(2,5 \%)$ & $3(1,5 \%)$ & $5(4,6 \%)$ \\
\hline -certificatie & $39(12,4 \%)$ & $33(16,1 \%)$ & $6(5,5 \%)$ \\
\hline Aantal ondernemingen & $314^{115}$ & $205^{116}$ & $109^{117}$ \\
\hline
\end{tabular}


Tabel 2.2: Reacties van concurremten met werscliillende marktinstrumenten (Percentage van de respondenten dat het betreffende instrument hanteert):

Reactio:

Totasl antal ondernemirigen:

Reactie met Con minsten:

var de marketing-

instrutonenten:

$214(69,9 \%)$

30611

$198^{119}$

$138(69.7 \%)$

$76(70,4 \%)$

Waarvan:

Produkt:

PKY

prestaties produkt

vormgeving

-Produdet plus:

garantievoorwararden

arvice bij aflewering

after-sales service

verkoopvoorwatrden

-Nieuw produkt:

nieuw prodiukt

assortiment

-Promotie:

promotie/ rieclame

verkoopacties

imago d.m.v. reclame

verrandering merknaam

-Prijs:

prijsverlaging

prijsverthoging

Distributie:

distributio
$156(72,9 \%)$

$138(64,5 \%)$

$51(23,8 \%)$

$13(6,1 \%)$

$28(13,1 \%)$

$6(2,8 \%)$

$4(1,9 \%)$

$14(6,5 \%)$

$9(4,2 \%)$

$60(28,0 \%)$

$43(20,1 \%)$

$26(12,1 \%)$

$80(37,4 \%)$

$30(14,0 \%)$

$39(18,2 \%)$

$36(16,8 \%)$

$6(2,8 \%)$

$79(36,9 \%)$

$75(35,0 \%)$

$5(2,3,4)$

$4(1,95)$

$4(1,9 \%)$

$\begin{array}{cc}107(77,5 \%) & 49(64,5 \%) \\ 94(68,1 \%) & 44(57,9 \%) \\ 38(27,5 \%) & 13(17,1 \%) \\ 9(6,5 \%) & 4(5,3 \%)\end{array}$

$17(12,3 \%)$

$11(14,5 \%)$

$3(3,9 \%)$

$2(2,6 \%)$

$5(6,6 \%)$

3. $(3,9 \%)$

$9(6,5 \%)$

$6(4,3 \%)$

$26(34,2 \%)$

$16(21,1 \%)$

$15(19,7 \%)$

$11(8,0 \%)$

$35(46,1 \%)$

$14(18,4 \%)$

$20(26,3 \%)$

$\begin{array}{cc}21(15,6 \%) & : \quad 15(19,7 \%) \\ 3(2,2 \%) & 3(3,9 \%)\end{array}$

$\begin{array}{cc}21(15,6 \%) & : \quad 15(19,7 \%) \\ 3(2,2 \%) & 3(3,9 \%)\end{array}$

$50(36,2 \%) \quad 29(38,2 \%)$

$50(36,2 \%) \quad 25(32,9 \%)$

$1(0,7 \%) \quad 4(5,3 \%)$

$2(1,4 \%) \quad 2(2,6 \%)$

$2(1,4, \%) \quad 2(2,6 \%)$

I18 306 vam de 317 ondernemingen versitrekten informatie over de reactie van de belangrijkste concurrent.

198 van de 206 ondememingen verstrekten informatie over de reactie van we belangrijkste concurrent. concurrent. 
Tabel F.2.b.: Verschil in reactie-intensiteit en -snelheid (Tussen hakjes de standaanddeviatie van het gemidưlelde).

\begin{tabular}{|c|c|c|c|}
\hline & Totaal & $\begin{array}{l}\text { ID-groep } \\
\text { (gemiddeld) }\end{array}$ & $\begin{array}{l}\text { CND-groep } \\
\text { (gemiddeld) }\end{array}$ \\
\hline $\begin{array}{l}\text { Reactie-intensiteit } \\
\text { (aaintal instrumenten } \\
\text { (21): }\end{array}$ & $\begin{array}{l}1,76(0,10) \\
\mathrm{n}=306\end{array}$ & $\begin{array}{l}1,63(0,11) \\
\mathrm{n}=198\end{array}$ & $\begin{array}{l}1,82(0,17) \\
\mathrm{n}=108\end{array}$ \\
\hline $\begin{array}{l}\text { Reactie-snelheid } \\
\text { (aantal maanden) }\end{array}$ & $\begin{array}{l}9,79(0,66) \\
n=125\end{array}$ & $\begin{array}{l}10,42(0,83) \\
\mathbf{n}=81\end{array}$ & $\begin{array}{l}8,11(1,10) \\
n=44\end{array}$ \\
\hline
\end{tabular}

Tabel F.3.: Gepercipieerde marktaandeelwinst en netto resultant naar aanleiding van PKV"nn ${ }^{123}$.

Groep: Total: ID-groep: CND-groep:

Netto resultant?

Merkbare verbetering netto resultag:

Geen merkbare verbetering:

$171(58,0 \%) \quad 108(56,3 \%) \quad 63(61,2 \%)$

Geen merkbare verbetering:

$24(42,0 \%)$

$84(43,7 \%)$

$40(38,8 \%)$

Totale respons:

295 (100\%)

$192(100 \%)$

$103(100 \%)$

\section{Marktaandeel?}

Lager:

$2(0,7 \%)$

$2(1,0 \%)$

$0(0,0 \%)$

Gelijkblijvend:

$85(28,1 \%)$

$58(29,6 \%)$

$27(25,5 \%)$

Enigszins hoger:

$152(50,3 \%)$

$99(50,5 \%)$

$53(50,0 \%)$

Beduidend hoger:

$63(20,9 \%)$

$37(18,9 \%)$

$26(24,5 \%)$

Totale respons:

$302(100 \%)$

$196(100 \%)$

$106(100 \%)$

121. Verschil statistisch niet significant met $p<0,10$.

: 22

Statistisch significant verschill met $T=1,86, p=0,067$; het aantal waarnemingen is laigg vanwege oen hoge non-respons op deze vraag. Bij het interpreteren van de uitkomsten dient hierme rekening gehouden te worden.

Hoger marktaandeell \& merkbare verbetering netto resultaat bij totale groep, respectievelijk IDgroep: $52 \%$ en $48 \%$. 


\section{Bijlage G. Categorie-indeling van de door de respondenten verstrekte omschrijvingen van de produktkwaliteits- verbeteringen}

De indeling van de PKV'n is gebaseerd op de indeling van Garvin (1984b). Garvin maakte onderscheid in 8 soorten PKV'n.

1. "Performance"; de fysieke primaire kenmerken van het produkt.

2. "Features"; de "toeters en bellen" van het produkt.

3. "Reliability"; de betrouwbaarheid.

4. "Conformance"; de overeenstemming met de specificaties.

5. "Durability"; de duurzaamheid.

6. "Serviceability"; de service-vriendelijkheid.

7. "Aesthetics"; de afwerking en "schoonheid".

8. "Perceived quality"; de reputatie en ongrijpbare produktkenmerken.

Om een vergelijkbare indeling te maken van de PKV' $n$ in ons onderzoek is door de onderzoeker een indeling gemaakt. Voor de validering van deze indeling is een beroep gedaan op een viertal beoordelaars, die ervaring hebben op het gebied van kwaliteitsvraagstukken.

Hiervoor zijn de bovenstaande omschrijvingen van de 8 soorten PKV n, samen met de lijst van de door de respondenten gegeven omschrijvingen van de PKV' $n$ aan 3 externe deskundigen en een student van de Economische Faculteit ${ }^{124}$ gezonden. De vraag aan de beoordelaars luidde "een zo goed mogelijke indeling van de 206 PKV'n te realiseren met behulp van de 8 soorten PKV"n".

Door de resultaten van de indelingen door de genoemde 4 beoordelaars te vergelijken met de categorie-indeling van de onderzoeker zelf bleek dat voor PKV'n in een industriële markt de afbakening, door middel van de bijgevoegde omschrijving, van de achtdeling niet geheel voldeed. In 145 van de 206 gevallen bleek dat drie van de vijf beoordelaars het eens waren over de categorie-indeling. In de overige gevallen was men het dus niet met elkaar eens ${ }^{125}$. In een tweede ronde zijn de indelingen nogmaals met elkaar vergeleken, echter nu met behulp van een aantal extra criteria woor elke categorie, om de grenzen tussen categorieën beter te kunnen bepalen. De extra criteria kunnen er overigens wel voor zorgen dat de oorspronkelijke indeling van Garvin niet meer zuiver wordt gevolgd. Bij het interpreteren van de uitkomsten dient men hier rekening mee te houden. Deze extra criteria zijn: drs. P.F.M. Jaspers (Nationale Investeringsbank, "S-Gravenhage), drs. R.J.M. Vogells (Economisch Instituut voor het Midden en Kleinbedrijf, Zoetermeer). 
1. Performance: Indien sprake is van betere mechanische eigenschappen en/of betere materialen, voor zover dit niet verder omschreven wordt in termen van verbetering van betrouwbaarheid of duurzaamheid van het produkt.

2. Features ("toeters en bellen"): Hieronder wordt ook begrepen het documenteren naar de klant toe en verbetering van de verpakking.

3. Reliability: Inclusief veiligheid.

4. Conformance ("conformering aan specificaties"): Hieronder wordt ook begrepen (integrale) kwaliteitszorgprogramma's c.q. het voldoen aan ISO/NEN/AQAP normen. Eveneens vallen procesverbeteringen onder deze categorie. Immers de vraag aan de respondenten in het onderzoek handelde expliciet over PKV' $n$. Een dergelijke PKV vindt zijn oorsprong derhalve in een procesverbetering.

5. Durability: Inclusief begrippen als corrosiebescherming, conservering en "verzinken" hetgeen leidt dot verhoging van de duurzaamheid van het produkt.

6. Serviceability: Deze categorie krijgt een ruimere interpretatie in de industriële markt. De service rond de levering wordt hier eveneens ondergebracht. Voorbeelden zijn levertijden, (technische) begeleiding en advisering.

7. Aesthetics ("vormgeving"): Geen nadere afbakening.

8. Perceived Quality: Deze categorie krijgt eveneens een ruimere interpretatie. De uitstraling van andere produkten en reputatie kan ook plaatsvinden door middel van assortimentsverbreding, vakmanschap en klantgerichtheid.

Hieronder is een lijst opgenomen met achtereenvolgens de produktomschrijving, de PKV en de betreffende categorie-indeling. Bij de indeling was het mogelijk meer dan eén categorie aan te wijzen per PKV. In totaal was het voor 54 PKV'n nodig twee categorieen te benoemen en voor een drietal PKV'n drie. De overige 149 PKV'n waren te karakteriseren door middel van één categorie. Tabel G.1. geeft een uitgebreid overzicht van de produktomschrijvingen, PKV'n en de toegekende categorieën.

Tabel G.1, Omschrijwing van de produktkwaliteiltsverbeteringen en de indeling in categorie(ën).

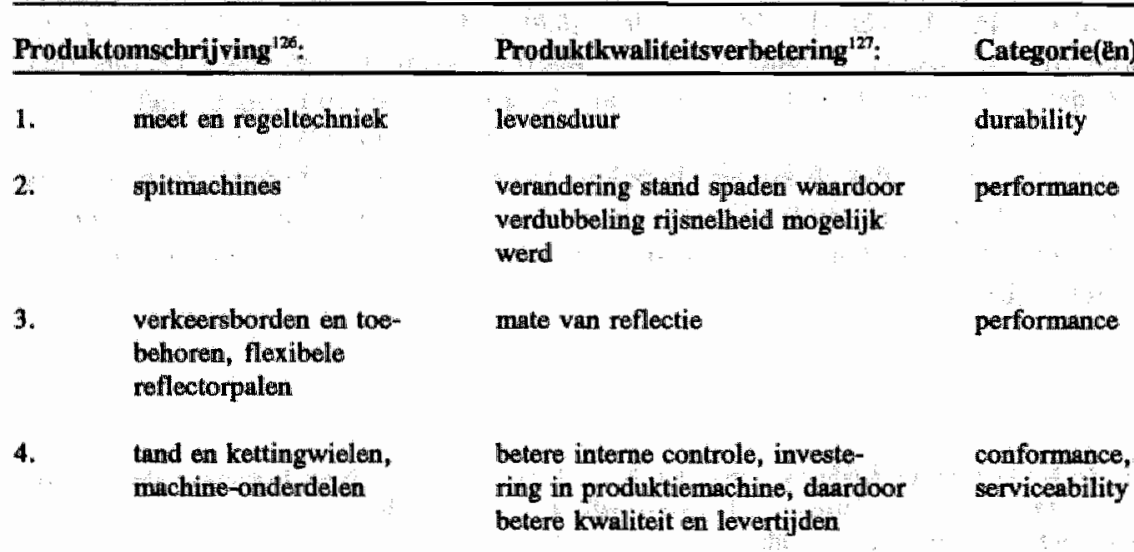


5. inwasieve bloeddrukmeet disposables

6. wielen (metal) voor luchtbanden

7. verpoedlering van kunststoffen in opdracht en op specificatie

8. verf

9. mylon of wollen tapijten

10. stalen nagels

11. textiel

12. verf

13. laboratorium apparatuur

14. vloeistof verstuivers

15. betonafstandhouders, konussen, kruisstenen, stelribben

16. machinebouw

17. spuitgieten voor derden van kunststof onderdelen en produkten

18. auto-, deur- en hillmatten

19. staalschroot in vorm yan onttinde pakketten

20. fruitsorteermachines

21. luchtgekoelde kleine transformatoren

22. electronische en electrotechnische componenten voor aandrijf en besturingstechniek veruadening in materialkeuze en opstelling

finishing, verbeterde matvoering

meer diensten die beter op bestasinde diensten zijn afgestemd

milieuvriendelijker/applicatiewriendelijker

kleurstelling of rugverankering

verbetering mechanische eigenschappen

betere bewerkbaarheid, betere uniformiteit

verwerkbaarheid/probleemoplossing /duurzaamheid

performance

wijziging construetie, wijziging produktiemethode

materiaalkeuze

mechanische verbeteringen

integraal

afwerking

nieuwwe fabriek met verbeterd procédé

toepassing van kunststof

energiezuinige produkten

verhoging van de gebruiksvriendelijkheid performanice, durabillity

conformance, gesthetics

perceived quality

performance

performance, features

performance

performance, conformance

performance, durability

performance

performance, conformance

performance, durability

performance

conformance

nesthetics

conformance

performance, durability

performanice

performance 
23. verpakkingen golfkarton

24. verpakkingamaterial

25. machines woor die suikerindustrie

26. industriele branderinstalliaties voor gasvormige en vlbeibare brandistoffen

27. verpakkingsmaterialen

28. drankenbussen

29. coatings

30. snelmontage systeem woor dubbellucht en kooiwielen voor tractoren

31. automatisering voor de biscuit-industrie

32. rookgasafvioer produkten, airconditioning en ventillatie produluten

33. schoenreparatiemachines

34. noodverlichting systemen

35. tuin- en campingmeubilair (t toellevering potplanten, diverse soorten dienstverlening), winkelinterieurs

36. schuifdaken voor autoindustrie

37. polyurethasm gecosguleerde produlkten, met als topper de synthetische huishoudzeem

38. diepdruk cilinders

39. gestanste artikelen in koper en messing beter gebruik gromistoffen

conformance

chemische bestendigheid

perfiormance

Wijziging constructie, waardoor machinelengte van ong. 45 meter is teruggebracht tot 15 meter

verbetering, uitbreiding tochnische prestaties en gebruiksmogelijkheden

performance

aanschaff nieuwe produlktieapparatuur

conformance

het uiterlijk

aesthetics

verwerkbaarheid, thoepasbaarheid

performance

betere controle bij montage,

veranderen wan getrolken schroefdraad naar gerolde schroefdraad

performance

verwerkingssnelheid produlten en hun soort

NEN 7203

conformance

lager geluidsniveau

aesthetics

vormgeving

aesthetics

voorkomen breuk armleggers, door andere samenstelling kunststof

durability

visuele verbeteringen en electrische uitvoering

festurines, aesthetics

duurzaamheid en kostenverlagende presentatie

durability, "aesthetics

conformance

conversie systeem in produktie

aesthetics 
40. conische verpaklkingen (bekers)

41. verven en coatings

42. liquid erystal displays

43. bevestigingsmaterianl voor daken

44. filtermaterial voor luchtfiltratie

45. oppervlakte bewerking (galvano)

46. verf, polynurethasin

47.

$$
\text { philite en metalen }
$$
onderdelen

48. koelunits op vrachtwagens

49. archiefmappen/hangmappen

50. steenwol isolatieprodukten

51. tankwagens voor LPGvervoer

52. toelevering van fijnmechanische onderdelen

53. stalen percisiebuizen

54. het fabriceren van corstukjes

55. installatietechniek

56. zware machines; zuigercompressoren, gasturbines

57. plaatbewerkingsmachines, scharen, persen, zetbanken, CNC-ponsen etc.

58. afsluiters voor de chemische en petrochemische industrie andere basisgrondstoffen, whardoor bedrukkingsmogelijk heden zijin verbetend

applicatie en duurzasmbeid

durability

grotere betrowwbasheid, levensduur

reliability, durability

betere machines

conformance

betrouwbuar produkt, accurate levering reliability servicesbility

leveringsbetrouwbaatheid

serviceability

applicatie, duwrzaamheid

performance, durability

belangrijk betere maatnguwkeurigheid

conformanice

vergroting betrouwbaarheid

reliabillity

werpakkingsmethode

features

verbeteringen in de stevigheid

performance

lichter eigen gewioht, door sterker materizal

documenten vam keuringsresultaten

features

nieuwe grondstoffen

performance

performance, conformance

performance produkt beter geworden

wijzigingen in verband met schade (overbelasting)

performance, reliability

hogere nauwkeurigheid, levertijden performance, service ebility

uitwisselbarheid

performance, features 
59. beeldversterkerbuizen voor nachtzichtapparatuur en verkoop wan know-how voor de produktie van beeldversterkerbuizen

60. techniseh wettenschappelijke meetsystemen th sensoren

61. technissh hoogwaurdige kunistatof spuitgietprodiuten

62. pallet en palletteermachines, industriele dienstverlexing

63. verpakkingen

64. keramische wand/vloertegels

65. smeerapparatuur voor do bakkerij

66. copiers, fax-apparatuur, laserprinters, serviceverlening en supplieslevering

67. tapijtgarens en meubelstofgarens in $100 \%$ wol

68. gasmeters

69. het toeleveren ann de fijnmechanische industrie

70. grondstoffen voor de verfindustrie

71. vernieuwen/coveren banden

72. revisie van verbrandingsmotoren, produktie van ruilmotoren (werbrandingsmotoren)

73. fabricage van precisieonderdelen en apparaten op specificatie verbeterde specificatiepunten zoals beter scheidend wermogen, gevoeligbeid, signaal/ruis verhouding

niet in principe, wel in vormgeving en betrouwbsarheid

material en vormgeving

compacter gebouwd, moderne besturing

verpakking, constante kwaliteitsbewaking

features, conformance

verpakking nieuw produkt

features

verbetering van spuittechniek, inzake vermindering vervuiling

assortimentswerbreding

performance

perceived quality

performance verbindingen en hierdoor verbetering van verwerkbaarheid

opwoeren van de nauwkeurigheid wan performance het produkt

AQAP keuringen en proceskeuringen ingevoerd

steeds engere specificaties

performance

performance

rubbercompound/profiel

performance

verbetering in eindafwerking en meer compleet maken van het produkt

nieurwe fabriek en machines, calibratiesysteem

conformance 
74. handel en engineering van compleet hydraulische aandrijvingen, daarnaast produlktie van industrialle deuren

75. implantaten

76. orthodontische apparaturur

77. persoonlijke beschermings produkten

78. walsdraad

79. schepen

80. transportinstallaties

81. fabricage offshore boorplatforms en andere staalconstructies

82. glasvezel

83. de aanleg van industriēle pijpleidingsystemen

84. het mechanisch bewerken van onderdelen van metalen of kunststof

85. project tapijt voor speciaal gebruik

86. kleurnengsystemen/kleurpasta's

87. verf

88. geslepen produlkten, toelewering

89. röintgen analyse apparatuur diverse technologische ampassingen

conformances invoeren kwaliteitsbelleid binnen de gehele onderneming

callciumbekleding van heupinplantaat zodat botingroei mogelijk is

betere grondstoffen en service

performance, serwiceability

uitbreiding glaskeuze en afwerking

features, aesthetics

opgesschoven naar hoger gelegeerde. staalsoorten

performance, durability

conformance

overdekt bouwen, is niet alleen produktieverbetering maar eerder ook kwaliteitsverbetering

duurzamheild en gebruiksgemak vergroot

performance, durability

wastleggen verantwoordelijkheden etc. conformance in procedires en verificatie op de implementatie

andere procestechniek

conformance

prefab-shop gereorganiseerd

conformance

$\mathrm{QA} / \mathrm{QC}$ procedures ingevoerd

verwerven CIMEI-certificaat

conformance

aesthetics

performance

optimalliseren van diverse eigenschappen

scheepsverf met $2 x$ langere

levensduwr, verf zonder

oplosimiddel

performance, durability

conformance

integrale kwaliteitszorg ingewoerd

perfiormance, reliability analytical performance en betrouwsbasarheid 
90. bus c.q. blik

91. veiligheidskleding

92. gietijzeren halffabrikaten voor vrachtwagenindustrie

93. technische toelevering metsal kunststafsamenstellingen en uniformuitrusting technische kennis

94. bouwverven

95. aluminium voorlegeringkorrelverfijner

96. cyclomeaiers

97. plotters

98. advisering en levering van klimantsystemen

99. autominiaturen aluminium $^{2}$ ramen en deuren t.b.v. de kassenbouw, autobedrading t.b.v. Volvo/Daf

100. tapijttegels

101. wandtegels en vloertegels

102. mechanische en electronische onderdelen en machines

103. automateriallen: trekhaken equipment:

104. ellectrische regellbare aandrijvingen

105. grondstoffen voor de kunststofverwerkende industrie, belangrijkste produkt: LLDPE = lineaire lage dichtheid polyetheen

106. tinnen gebruiks- en siervoorwerpen

107. textielveredeling van katoen en mengwweefsels werandering van gefelste folie naar gesealde uitvoering

betreft steeds kleine verbeteringen

performance

minder fouten, stiptere leveringen

conformance, serviceability

conformance, serviceability van $k$ waliteit, aanpassen organisatie kلlantenservice

kwaliteitsverbetering in een

conformance stroom-model

verlaging insluitselniveau

performsince

bedieningscomfort, veilligheid, finishing verhoging machinecapaciteit

performance, reliability

snellheid en accuratesse

conformance

aantonen van het vakmanschap in de advisering

perceived quality

beter lakwerk en tamponbedrukkingen

durability; aesthetics

geschiktheid voor computerruimten

performance

verlaging van de sorteerslippers

conformance

nauwkeurige machines met grote

conformance

snelheid produceren

corrosiebestendigheid, verpakking

features, durability

het wisselen van thet "hart" vam thet systeem

performance

andere samenstelling van het produkt performance

afwerking, kleuringsprocesd, nieuwe modellen

aesthetics, perceived quality

over de gehele limie verbeteringen asngebracht middels handboeken conformance 
108. machines voor de rubberverwerkende industrie

109. audiomixers

110. vermogenshalfgeleiders

111. medisch produkt: intraoculaire lenzen (implanteerbare ooglenzen voor staaroperatie)

112. walsblokken-voor walserijen, instillatie nieuw gietisysteem voor persstaven voor perserijen persstaven waardoor hogere perssnelheden voor perserijen

113. kale en bestuckte printpanelen

114. vlinderklep afsluiters

115. staalconstructies, diverse metaalwerken

116. landbouwwagens

117. haarcosmetica-artikelen t.b.v. chemische samenstelling (van kapsalongebruik :

118. trekhaken

119. 2ware vrachtwagens

1.20. laksystemen voor industriele toepassing

121. speciale gereedschappen speciale machine-onderdelen

122. installatiedraad en -kabel alkalisch naar zuur)

corrosiebescherming

betere gromdstoffen, betere metallisch logen, antistatica, mechanische bewerkingen

overnemen van recente ISO-normen, materiaal verbeteringen, constructie aanpassingen

het leveren van een kwalliteit die eerst alleen de concurrentie had

randen, verf, aanzicht, merknaam, grootte, cilinders, lagers, lagerbussen trekpen

dubbelzijdig verzinkt plaatmateriaal in gebruik genomen woor de vervaardiging van Scania-cabiness

samenstel van werbeteringen

technische prestatie, gebruikte materialen, correct tijdstip aflevering, durrzaamheid

verhoging veiligheid (t.a.v. brand) conformance

performance

performance

performance, features

performance, conformance

performance

conformance

performance

performance, aesthetics

performance

durability

durability

performance

performance, durability, perceived quality

reliability 
123. industrite dienstverlening/ reparatie, montage, onderhoud/componenten rollend matented, draaim stellen/ bullkoniterial handling/ gastarbine componenten

124. gasgegtookitu infraroou verwarmingstoestellen

125. 1ang-en middenspamaingsinstallaties

126. lijmen

127. pantalonistoffen

128. dewren en luiken voor voor scheepviant, industriele wasmachines

129. vemakkingamateriaal woor medilusche kumstistoffien; PVe-zakken (bijw, infurus-, urine, voedingouak)

130. vlinderklep fsluiters

131. maaiers voor fruitteelly veeteelt, maniers voor communale sector, dorsers voor ontwikkalingellanden

132. centrifugaalpompen en senvice

133. complexe bewerking on hoge natw keurigheidsgraad

134. PVC-bouwprofielen invoering van ees kwaliteitsugteem op basis yan NEN 2647

ontsteking van het toestel

weiligheid wan het produkt

verbeterde verwerkbaarheid

kwallitativef betiene grondstoffen en betere eindafwerking (in toon)

finetionaliteit

ergonomische en bilologisthe vertbateringen conformance

performance

reliability

perfomance

performance, aesthetics

performance

performance

conformance

dir. type goedkeuring door derden (Lloyds), voldoen aan (inter)nationale standarden (ISO), certificatie

technische vervolmaking is een continu proces bij alle produkten

performance

andere materialen in combinatie met performance unieke eigenschappen (probllem solwing)

verbetering machinepark; ontwikkeling conformance kwaliteitszorgsystemen

nieuwe ontwikkeling van hoofdprofielen (KOMO-gekeurd)

performance, conformance

performance, conformance artikelen en regeneraat produkt, andere produktietechniek

conformance instructies personed en werkvoorbereiding derden

137. transporteurs voor bulkgoed nawweunigheid, standaardisatie

conformance bindkwaliteit, letterkwaliteit

performance 
139. eenheden voor luchtweef- flexibiliteit van inzel

perforinanes machines:

140. buitenrioleringsprodukten

141. stijlplaten

142. het electrotechnisch lakken van metallen produkten voor derden

143. A.C.-installaties; fabriceren monteren en onderhoud, systeemvloeren/wranden/ plafonds- fabriceren en onderhoud

144. apparatenbouw woor de petrochemie en onderdelen nucleair magnetic scanners

145. gladheidbestrijdingsmachines

146. nonwoven, disposable textielprodukten variërend van zjekenhuismuts en verbandgaas tot tafelkleden en poetsdoek alswel cowers

147. printed circuits boards

148. technische onderdelen van kunststof

149. brandweervoertuigen

150. reddingsgereedschappen voor brandweer, hydraulische cillinders van 5-500 ton

151. kunststof gevelelementen

152. computers, services onderhoud

153. kunststoffen stampprodukten martrijzen en stempels

154. gekcelde toonbanken vele kleine aanpassingen, assortimentsuitbreiding

maattechniek

procesverbetering zodat het beter beheersbaar is

duurzaamheid, energiezuinigheid

performance, durability

maattoleranties gehalveerd

conformance

durability

performance

ontwikkeling nieuwe technieken waardloor betere produkten; beter afgestemd op specifieke wensen van de klant

ankinopen nieurwe nauwkeurige machines en automatisering

"zero defect" lewering en "just in time" llevering

certificatie AQAP-4

conformance

betrouwbaarheid ergonomie, meer kracht, lager gewicht

performance, relliability

performance

systeenuverbetering, uitbreiding toepassingsmogellijkheden

betrouwbagrheid van de systemen, introducties van nieuwe opties

features, reliability

performance, conformance

betere materialen invoeren em matrijswerbeteringen, stabiele kwaliteit

bevochtiging, besturing (electronisch) performance, ruitten fentures 
15s. zinkoxydes

156. Kunststof apparatenbourw baden (stad en bekleding) afruiginstallaties, leidingwerk/monttage

157. complete produltie ingtallaties voor anidappel, friter , chips- smationod

158. warmtebehandeling van atalen

159. dikwandige verpakkingsartikelen (kratten en bakken)

$160 . \quad$ isilikaten (cherwische produkten)

161. technische kunststof spuitgietprodukten

162. expandeerbaar pollystyreen

163. Lammair flow installaties

164. coatings voor industrieel onderhoud

165. onderwaterpompen

166. meryllaatplaten (pmima)

167. produktie prefab beton alementen voor de bouw

16:3. kunststof profielen prodichlio

169. toeleverimg antomobielindustrite

170. landbouwwerktinigenfrabricatice

171. toelewering plaatwerk, Adtronische assemblage, apparaten bouw hoggere chemische zuverheid

performance

lasmethode, onderstentning en leiding- durability werk

nieuwe technologische concepten

pierformance

procesbebeersing

conformance

wormgeving en constructief

performance, aesthetics

chemische samenstelling (zuiverheid)

performance

een zeer llaag afkeurpercentage,

conformance bezig met certificering

koeltijdverkorting, waardoor kortere verwerkingstijid bij afnemers mogelijk wordt

patentregeling

performance

vervanging van schadelijk roestwerend pigment zondler verlies aan kwalliteit

rendementsverbetering

performance

minder vuil, betere dikte-afmeting

performance, conformance

sparingen

performance

aampassing modelleringen, betere grondstof inzetten

performance

beigelleiding, planning eindcontrole

conformance

jaarlijkse aanpassing

performance

invoering kwaliteitsborgingssytemen

conformanice 
172. nom-ferro halffabriketen: dunine band van koperlegieringean

173. kapitaalgoederen t.b.v. energitievoorziening (utility plants)

174. moveren

175. stalen veiligheidsmenzen

176. magneetventielen

177. medical-kmaging produkten

178. oppervlaktebehandeling en bescherming

179. verfprodukten

180. intra-oculaire lenzen

181. schakel- en verdeelkasten

182. soldeermachines met de daarbji behorende transportsystemen

183. oppervlakte reinigingsmachines (veeg- en schrobmachines)

184. flatbed recorder

185. katalysator, organophosphorverbinding

186. C. V.-ketel in geslloten uitvoering of ventillationen

187. connectoren en machines bestemd voor llanten om onze produkten te gebruiken

188. technische verea

189. tapijt verbeteringen $t, a, v$, vlgikbeit band, afmetingstoleranties, comosilebestendigheid

rendement en milieutechnische kwaliteit

controle werbetierd

andere produktiemethode, daurdoor mavatwaster

redesign, kostprijswerlaging

upgrading serie

voorkomen van tekorthomingen

produktkwaliteit t, $0 . v$. wensen afnemers, aflevering, technische documentatie

afrondingen

grotere mechanische sterkte bereikt, hierdoor minder breuk bij verwerking en transport

onderhouds-/servicevriendelijkheid.

technische prestaties, ergonomisch, veiligheid, ontwikkeling exitra's

nauwkeurigheid, veiligheid

zuiverheid dusdanig dat de katalysuttor in alle processen toegepast kan worden

lassen van de warmtewisselaar

corrigerende acties t.o... . Klachten, beheer van documentatie

kwaliteit, levertijd, technische begeleiding

duurzaamheid conformance

serviceability

conformance, durability

performanice

conformance

performance

perceived quality

conformance

performance, features, servicenbility

performance

performance

performance. features, reliabillity

performance, relitability

performance

reliabilitty. durability

confformance

performance, serviceability

dumbility 
190. glaswol

191. Landbourmachicies,

poederkwinlitudt

perfiormance

"high-tech" produkten

voor de landbotiw

192. cornosiewerende produkter

bestendigheid van kwaliteit

conformance

voor sutcomobiellen

(MLliunderbody coating)

193. Listoevoegmateriaal

lasbaarbeid vain entral electroden

perfiormance

(laseloctroden)

194. assemblage van printplaten

annschaf marconi-tester, wat

"zero faults" garandeent

conformance

195. chemische toiletten

aanschaf computergestuurde spuitgietmiachines

196. rolstowlen (hand/electrisch) modulariteit

features

en in algemene $x$

revalidatieapparaten

197. garderobe systemen

coatsafe diefstalbeweiliging

features

198. whepen

bewapening en loefbarareid

performance

199. zwarel middelzware

ontwerpverbetering

performance

compressoren; machinebouw

200. tegellijmen behanglijmen verwijderen asbest wit tegellijm

performance

201. civiele bouw, industriële dienstverlening

agnbieden van op de cliênt toegesneden oplossing, kemis in ervaring personeel

202. hechtmaterialen

uitbreiding van het toepassingsgebied van niewwe materialen

perceived quality

203. dakbedekking, betondakpan modelwijziging, wijziging toebehoren

features, aesthetics

204. zelfklevende verpakkingstape materiaal is te gebruiken bij lagere

perfiormance temperaturen alls voorheen

205. handel in papier, fabricage enveloppen

papiersoorten, algemene kwaliteitsverbetering

206. flexibole schuummaterialen technische kwaliteit verdubbeld

performance 


\section{Bijlage H. Verantwoording en uitkomsten van de multivariate analyse-technieken; regressie-analyse \& discrimi- nant-analyse}

Deze bijlage bestaat uit twee delen. Het eerste deel (H.1.) geeft de uitkomsten van een meervoudige regressie-analyse om de invloed van de modelvariabelen op de RI te bepalen. Het tweede deel (H.2.) geeft de uitkomsten van een discriminant-analyse om het belang van de modelvariabelen in te schatten ten aanzien van het succes van de PKV.

H.1. De verklaring van de reactie-intensiteit met behulp van een meervoudige regressie-analyse

Tabel H.1. bevat de uitkomsten en statistische kenmerken van de regressie-analyse met als afhankelijke variabele de reactie-intensiteit en als onafhankelijke variabelen achtereenvolgens de variabelen uit de hypothesen (model 1), model 1 aangevuld met enkele marktkenmerken (model 2) en model 2 aangevuld met de genoemde aanleidingen voor PKV'n (model 3). De tabel is verspreid over twee pagina's.

Tabel H. 1.: Meervoudige regressib-analyse: Intensiteit van de concurrentiele reactie en verklarende variabelen (vermeld staan de $\beta$ 's $* 100$ en tussen haakjes de p-warde behorende bij de Trtoets) ${ }^{123}$.

\begin{tabular}{llll}
\hline & Model 1: & Model 2: & Model 3: \\
Variabelen in regressie: & PLC, Soort & Markt, Soort & Markt, Soort \\
& PKV, Resul- & PKV, Resul- & $\begin{array}{l}\text { PKV, Resul- } \\
\text { taat: }\end{array}$ \\
& taat: & & \\
\hline
\end{tabular}

Constante $^{120}$

$103(0,026)^{* *} \quad 228(0,008)^{* * *} \quad 1015(0,003)^{* * * *}$

$\operatorname{Markt}^{130}$;

1) Fase PLC(verzadiging)

2) Fise PLC(teruggang)

3) Marktaandeel (5-25\%)

4) Marktandeel ( $>25 \%$ )

5) Gebruikelijk PKV

6) Aantal concurrenten

$\begin{array}{ll}-3(0,739) & -9(0,308) \\ -17(0,031)^{* * *} & -24(0,004)^{* * *} \\ & -7(0,516) \\ & 7(0,705) \\ & 14(0,074)^{*} \\ & 14(0,073)^{*}\end{array}$

$-3(0,658)$

$-22(0,004)^{* * * *}$

$-6(0,530)$

$5(0,615)$

$18(0,015)$ ***

$16(0,031)^{* *}$

12 Significantie-niveaus op basis van tweezjulige T-toets: $*=p<0,10, * * p<0,05, * *=p<0,01$.

120 Bij de constante staat de waarde van $b$ in plaats van $\beta$ vermeld.

PLC: twee dummy variabelen; de samengevoegde introductie- en groeifase is opgenomen in de constante term.

Marktandeel: twe dummy vairabelen; marktaandeel $<5 \%$ opgenomen in constante term.

Gebruikelijk PKV door te voeren: $1=j a, 0=$ nee.

Aental concurrenten: In verband met scheve verdeling de logaritme van het aantal concurrenten $(+1)$. 
Resiltant a g. v, PKV ${ }^{33 i}$.

7) Netto resultant

Marktaandeel:

8) enigexins hoger

9) beduidend hoger

Soon PKY"127.

10) Performance

11) Features

12) Reliability

13) Conformanes

14) Durability

15) Serviceability

16) Aesthetics

17) Perceived Quallity

Aanleidingen voor PKV'

Markt "pull":

18) Wensen afnemers

19) Wensen gebruikers

20) Ontevredenheid afnemers

21) Ontevredenheid gebruikers

Organisatie "push" ".

22) Technische mogelijkheden

23) Verandering organisatie

24) Beschikbaarheid kapitaal

Concurrentie:

25) PKV concurrentie

26) Andere actie concurrentie

Derden:

27) Overheidsmaatregelen

28) Consumenteninstanties

29) Certificatie-eisen

$\mathbf{R}^{2}:$

$\mathbf{R}^{2}$ ("adjusted"):

F-waarde:

Af regressie/residu:

significantie p:

$$
\begin{gathered}
-21(0,017)^{*} \\
2(0,796)
\end{gathered}
$$

$27(0,013)^{* *}$

$29(0,000)^{* * * *}$

$18(0,023)^{* *}$

$13(0,229)$

$7(0,381)$

$7(0,374)$

$16(0,044)^{* *}$

$19(0,015)^{* *}$

$$
\begin{aligned}
& 16(0,067) * \\
& -25(0,009)^{* \cdots \cdots} \\
& -4(0,705)
\end{aligned}
$$

$22(0,058)$

$22(0,010)^{* * *}$

$28(0,000) \cdots$

$10(0,410)$

$1(0,897)$

$13(0,103)$

$5(0,558)$

$23(0,004)^{* \cdots *}$
$14(0,073)^{*}$

$-21(0,017)^{* * *}$

$-5(0,597)$

$13(0,208)$

$13(0,107)$

$25(0,000)^{* * * *}$

$-6(0,590)$

$-4(0,619)$

$12(0,123)$

$1(0,859)$

$13(0,085)^{*}$
7. $(0,371)$

$8(0,284)$

$12(0,125)$

$11(0,134)$

$13(0,089) *$

$26(0,001)^{* * * *}$

$16(0,036) * *$

$13(0,085)$

$18(0,010)^{* * *}$

$10(0,168)$

$10(0,151)$

$9(0,217)$

0,502

$0,381^{134}$

4,142

$29 / 119$

$<0,0001$

13i Codering van de verschillende categorieēn vollgens $1=$ ja en $0=$ mee.

192 Codering wan de verschillende categorieën met $1=$ ja en $0=$ nee.

13. Elk motief wordt voorgesteld door een dummy variabele, waarbij $1=$ ja en $0=$ nee.

134 Overigens wordt door de regressie-analyse opnieuw uit te voeren, maar dan met slechts de statistisch siginificante variabelen $(p<0,10)$, de hier gepresenteerde uitkomst bevestigd, voor wat betreft het teken en de grootte van de $\beta$ 's. 
H.2. De bepaling van het belang en de invloed van de modelvariabelen voor het succes van de PKV; een discriminant-analyse

In deze bijlage wordt aangegeven hoe van een discriminant-analyse gebruik is gemaakt en welke resultaten zijn verkregen bij een poging tot het verklaren van het succes van PKV'n, in termen van marktaandeel en netto resultaat. Eerst wordt het gebruik behandeld. Vervolgens worden de uitkomsten besproken.

Discriminant-analyse is met name geschikt om een nominale afhankelijke variabelen te verklaren uit een aantal interval geschaalde onafhankelijke variabelen ${ }^{135}$.

Bij de volgende discriminant-analyses wordt gebruik gemaakt van lineaire discriminantfuncties. Eerst is een discriminant-analyse op basis van de hypothesen uit het model uitgevoerd. Vervolgens is een tweetal alternatieve specificaties van de verklarende variabelen opgenomen. Door de resultaten in de vorm van schattingen van coëfficiënten van deze specificaties te vergelijken, is het mogelijk om op een verantwoorde wijze enige samenhangen te beschrijven. Het doel van de discriminant-analyses is nadrukkelijk niet het indelen van de populatie in groepen (classificatie), maar het op exploratieve wijze verkennen van mogelijke samenhangen tussen enerzijds het succes van een PKV en anderzijds de modelvariabelen op basis van hypothesen en enkele andere specificaties ${ }^{136}$.

Achtereenvolgens wordt de verklaring van de marktaandeelwinst en van het netto-resultaat besproken.

Tabellen H.2. en H.3. bevatten eerst de schattingsresultaten ten aanzien van de marktaandeelwinst en het netto resultaat op basis van de variabelen uit het model (model 1):

1) Dummy voor een mix-PKV (PKV bestaat uit meer dan én van de oriëntaties produkt, produktie en gebruiker).

2) Reactie-intensiteit (RI).

3) Dummy voor het wel of niet baseren van PKV'n op zowel markt-"pull" als organisatie-"push" aanleidingen.

4) Fase in de produktlevenscyclus.

Wanneer een lineaire discriminantfunctie wordt gespecificeerd dan dienen strikt genomen de onafhankelijke variabelen multivariaat normaal verdeeld te zijn. In onze toepassing wordt getrucht een dichotome variabele marktaandeelwinst (geen hoger marktaandeel versus een hoger marktaandeel naar aanleiding van PKV'n) en netto resultaat (geen hoger netto resultaat versus hoger netto resultaat) te verklaren uit de modelvariabelen. Aan de eis dat voldakn moet zijin asun multivariaat normal vendeelde omafhankelijke variabelen is niet voldaan, omdat een substantieel deel van de variabelen dichotome variabelen zijn. In dit geval (een mixtuur van dichotome en continue variabelen) is een lineaire discriminantfunctie niet optimal. Uit ander ondlerzoek (Moore 1973, Gulbert 1968) zijn er echter sterke aanwijzingen dat een lineaire discriminantfunctie in dat geval toch goed voldoet. In geval wan dichotome verklarende variabelen is Box. $M$. toets voor het toetsen van de gelijkheid van de covariantiematrices gevoelig, omdat deze variabelen niet multivariaat normal verdeeld zijn. Ook in het geval van enigszins verschillende covariantiematrices en klein aantal waamemingen kan gebruik worden gemaakt van limeaire discriminantfunctio (Wahl \& Kronmal 1977).

Vergelijk de indeling wan Smith (1979) waarin in een van de vier cellen gedoeld wordt op het gebruik van discriminant-analyse om de discriminantfunctie te optimaliseren voor exploratiewe doeleinden en witdrukkelijk niet voor classificatie-doeleinden. 
Vervolgens zijn de onderliggende soorten PKV'n opgenomen in plaats van de dummy voor de mix-PKV (model 2), en zijn de afzonderlijke aanleidingen voor PKV'n toegevoegd in plaats van de dummy voor het wel of niet baseren op zowel markt-"pull" als organisatie-"push" aanleidingen (model 3). Tot slot zijn in model 4 de overige marktfactoren (aantal concurrenten, marktaandeel en gebruik in de branche ten aanzien van PKV'n) toegewoegd.

Voor de keuze van het beste model is enerzijds rekening gehouden met een acceptabel significantie-niweau van de discriminantfunctie $(p<0,10)$ en anderzijds met het behouden van zoveel mogelijk detail in de verzameling van verklarende variabelen. Dit heeft geresulteerd in de keuze van model 4 voor de verklaring van het succes ten aanzien van de marktaandeelvergroting $(p=0,025)$. Voor de verklaring van het succes ten aanzien van het netto resultaat is gekozen voor model $3(\mathrm{p}=0,081)$.

Tot slot dient te worden vermeld dat om pragmatische redenen de reactie-snelheid (RS) buiten de analyses is gehouden vanwege het geringe aantal waamemingen (81) van deze variabele. Tabel H.2. is verspreid over twee pagina"s.

Tabel H.2: : Discriminant-analyse: Marktaandeelwinst als gevolg van een PKV, verklaard uit de modellvariabelen. Gestandaardiseerde coëficiënten van de discriminant functie $\left({ }^{*} 100\right)$ en relatief discriminerend vermogen $(\%)$.

\begin{tabular}{|c|c|c|c|c|c|c|c|c|}
\hline \multirow{2}{*}{$\begin{array}{l}\text { Modelvariabelen: } \\
\text { Verklarende variabelen: }\end{array}$} & \multicolumn{2}{|c|}{$\begin{array}{l}\text { Model 1: } \\
\text { Mix-PKV, RI, } \\
\text { Aanleiding markt } \\
\text { \& organisatie, } \\
\text { PLC }\end{array}$} & \multicolumn{2}{|c|}{$\begin{array}{l}\text { Model 2: } \\
\text { Soort PKV, RI, } \\
\text { Aanileiding markt } \\
\text { \&organilsatie, } \\
\text { PLC }\end{array}$} & \multicolumn{2}{|c|}{$\begin{array}{l}\text { Model 3: } \\
\text { Soort PKV, RI, } \\
\text { Aanileiding \& } \\
\text { PLC }\end{array}$} & \multicolumn{2}{|c|}{$\begin{array}{l}\text { Model 4: } \\
\text { Soort PKV, RI } \\
\text { Aanleiding \& } \\
\text { marktfactoren }\end{array}$} \\
\hline & COEF $F^{137}$ & DIS $^{138}$ & COEF & DIS & $\mathrm{COEF}$ & DIS & $\mathrm{COEF}$ & DIS \\
\hline \multicolumn{9}{|l|}{ Markt ${ }^{139}$ : } \\
\hline 1) Fise PLC(verzadiging) & -87 & 51,1 & -71 & 38,0 & -67 & 32,7 & -59 & 24,2 \\
\hline 2) Fase PLC(teruggang) & -63 & 14,4 & -54 & 11,1 & -47 & 8,8 & -39 & 5,1 \\
\hline 3) Aantal concurrenten & & & & & & & 49 & 9,7 \\
\hline 4) Gebruik PKV branche & & & & & & & -29 & 7,5 \\
\hline 5) Marktaandeel (5-25\%) & & & & & & & -20 & 2,7 \\
\hline 6) Marktaandeel ( $>25 \%$ ) & & & & & & & 18 & 4,2 \\
\hline
\end{tabular}

137

19

Gestandaardiseer de coefficiềnt van de discriminantfunctie.

Het relatieve discriminerende vermogen wordt uitgedrukt als cen percentage $I_{\text {f }}$ (Mosteller \& Wallace 1963, Aw \& Waters 1974), waarbij I gedefinieend is als:

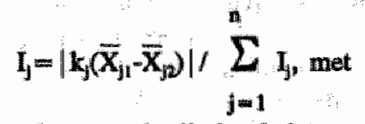

$I_{1}$ het waande die het belang aangeeft van de $j$-de variabele.

$\mathrm{k}_{\mathrm{j}}=$ de niet gestandaardiseerde coëfficiënt van de discriminant-functie voor de $\mathrm{j}$-de variabele.

$\overline{\mathrm{X}}_{\mathrm{j}}=$ het gemiddelde wan de $\mathrm{j}$-de variabele in de $\mathrm{k}$-de groep.

PLC: twe dummy variabelen; de samengevoegde introductie- \& groeifase is opgenomen in de constante term. 
Soort PKV ${ }^{1+0}$ :

7) Performance

8) Features

$\begin{array}{rrrrrr}30 & 2,6 & 35 & 2,8 & 19 & 1,5 \\ 26 & 4,6 & 28 & 4,5 & 17 & 2,1 \\ 33 & 11,1 & 31 & 9,6 & 20 & 4,4 \\ -3 & 0,5 & 0 & 0,0 & -21 & 4,4 \\ 16 & 2,2 & 17 & 2,2 & 11 & 2,0 \\ 32 & 8,9 & 34 & 8,6 & 34 & 7,7 \\ 15 & 0,7 & 21 & 0,9 & 20 & 1,3 \\ 14 & 0,4 & 12 & 0,3 & 11 & 0,2\end{array}$

9) Reliability

10) Conformance

11) Durability

12) Servicenbility

13) Aesthetics

14) Perceived Quality

15) Mix van soorten

$15 \quad 11,6$

Aanleidingen voor PKV ${ }^{144_{*}}$

16) Markt-"pull"

17) Organisatie-"push"

18) Concurrentie

19) Derden

20) Zowel markt-"pull" als organisatie-"push"

$\begin{array}{llll}45 & 15,3 & 39 & 11,9\end{array}$

Reactie:

21) Reactie-intensiteit (RI) $-43$

$7,5 \quad-53$

$8,3 \quad-47$

$6,7 \quad-36$

Canonische correlatie-

coefficiënt:

0,317

0,367

0,155

$\begin{array}{rrrr}-10 & 0,5 & 4 & 0,1 \\ 49 & 17,2 & 51 & 14,9 \\ -21 & 5,0 & -17 & 3,3 \\ 1 & 0,1 & -15 & 2,5\end{array}$

Eigenwaarde:

0,112

0,899

0,866

17,31

$23 ; 10$

$x^{2}$ :

df (graden van vrijheid):

0,004

12

0,027

significantie $p$

0,004

Groep "geen verhoging m.a.", $\mathrm{n}=$ ="

Groep "verhoging m.a.,$n=$ :

Elk motief wordt voorgesteld door een dummy variabele, warbij $1=\mathrm{ja}$ en $0=$ nee.

Dit percentage geeft een bovengrens asn. De wamemingen die gebruikt xijn om de discriminantfunctie te schatten zijn tevens gebruikt om de classificatie te bepalen. De percentages werden voldoende geacht om de discriminant ressultaten zinvol to interpreteren. Overigens zijn de classificatie-resultaten verkregen zonder weging met de a priori kansen in de steekproef. 
Tabel H.3.: Discriminant-anallyse: Verbetering van het netto resultaat alls gevolg van een PKV, verklaurd uit de modelvariabelen. Gestandaardiseerde coefficiënten van de discrimainant functie $(100)$ en relatief discriminerend vermogen $(\%)$.

\begin{tabular}{lllll}
\hline & Model 1: & Model 2: & Model 3: & Model 4: \\
Modelvariabelen: & Mix-PKV, RI, & Soort PKV, RI, & Soort PKV, RI, & Soort PKV, RI \\
& Aanleding markt & Aanleiding markt & Aanleiding \& & Aanleiding \& \\
& \& organisatie, & \& organisatie, & PLC & marktfactorean \\
& PLC & PLC &
\end{tabular}

Verklarende variabelen:

COEF DIS

COEF

Markt:

1) Fase PLC(verzadiging)

2) Fase PLC(teruggang)

$-33$

$13,6 \quad-14$

$-21$

$5,9-5$

2,0

-19
-5

2,6
0,4

$-22$

3,0

3) Aantal concurrenten

4) Gebruilk PIKV braniche

5) Marktaandeel (5-25\%)

6) Marktaandeel ( $>25 \%$ )

Soort PKV:

7) Performance

8) Featuress

9) Reliabulity

10) Conformance

11) Durability

12) Serviceability

13) Aesthetics

14) Perceived Quality

15) Mix wan soorten:

$57 \quad 39,9$

$\begin{array}{rrrrrr}3 & 1,4 & 1 & 0,6 & -7 & 2,8 \\ 30 & 5,4 & 29 & 4,8 & 14 & 1,9 \\ 8 & 0,2 & 8 & 0,2 & 4 & 0,0 \\ 73 & 28,8 & 65 & 24,3 & 49 & 13,0 \\ 68 & 25,5 & 66 & 23,2 & 66 & 27,2 \\ 51 & 21,1 & 47 & 18,6 & 48 & 18,4 \\ 36 & 5,8 & 35 & 5,2 & 31 & 3,5 \\ 20 & 2,2 & 18 & 1,8 & 16 & 1,7\end{array}$

Aanleidingen voor PKV:
16) Markt-"pull"
17) Organisatie-"push"
18) Concurrentie
19) Derden
20) Zowell markt-"pull" als organisatie-"push"

60

$$
29,4
$$

19

4,9

Renctio:

21) Reactie-intensitteitt (RI)

23

11,3

11

2,3

11

$2,1 \quad 10$

Canonische correlatie-

cosfficiënt:

0,163

0,353

0,372

0,409

Eigenwaarde:

0,027

0,143

0,160

0,201

Wilks.' Lambda

0,875

0,833

4,35

0,862

25,72

$5 \quad 12$

df (graden wan wrijheid):

significantie p:

0,501

23,13

19

0,052

0,138

56,4

65,5

0,081

67,8

73

73

69

92

92

73

83 


\section{Literatuur}

Aaker, D.A. \& G.S. Day, 1986, The Perils of High Growth Markets, Strategic Management Journal, 7, pp. 409-421.

Abbott, L., 1953, Vertical Quality Equilibrium under Pure Quality Competition, American Economic Review, 43, pp. 826-845.

Abbott, L., 1955, Quality and Competition: An Essay in Fconomic Theory, Columbia University Press, New York.

Abell, D.F. \& J.S. Hammond, 1980, Strategic Market Planning, Prentice-Hall Inc., Englewood Cliffs, New Jersey.

Abrams, B., 1981, Research Suggests Consumers Will Increasingly Seek Quality, Wall Street Joumal, October, 15th.

Absatzwirtschaft, 1988, ASW-Report: Der Neue Qualitätskult, Absatzwirtschaft, 6, pp. 30-41.

Alemson, M., 1969, Demand, Entry and the Game of Conflict in Oligopoly Over Time: Recent Australian Expierience, Oxford Economic Papers; July, pp. 220-243.

Alsem, K.J., P.S.H. Leeflang \& J.C. Reuyl, 1986, Accounting for Competition, Does it Really Matter?, in: Contemporary Research in Marketing. Proceedings of the XVth Annual EMAC Conference, K. Möller \& M. Paltschik (eds:), Helsinki, pp. 175-184.

Alsem, K.J., P.S.H. Leeflang \& J.C. Reuyl, 1989, The Forecasting Accuracy of Market Share Models Using Predicted Values of Competitive Marketing Behavior, International Journal of Research in Marketing, 6, pp. 183-198.

Ansoff, H.I., 1965, Corporate Strategy, McGraw-Hill, New York.

Archibald, G.C., 1964, Profit-Maximising and Non-Price Competition, Economica, February, pp. 13-22.

Arnold, E., 1985, Competition and Technological Change in the Television Industry, Macmillan Press Ltd. , London.

Aw, R.W. \& D. Waters, 1974, A Discriminant Analysis of Economic, Demographic, and Attitudinal Characteristics of Bank Charge-Card Customers, Joumal of Finance, 29, pp. 973-980.

Bain, J.S., 1956, Barriers to New Competition, Harvard University Press, Cambridge, MA.

Bass, F.M. \& L.J. Parsons, 1969, Simultaneous Equation Regression Analysis of Sales and Advertising, Applied Economics, 1, May, pp. 103-124.

Benzecri, J.P., 1969, Statistical Analysis as a Tool to Make Patterns Emerge from Data, in: Methodologies of Pattern Recognition, S. Watanabe (ed.), Academic Press Inc., New York, pp. 35-74.

Berry, L.L., V.A. Zeithaml \& A. Parasuraman, 1990, Five Imperatives for Improving Service Quality, Sloan Management Review, 31, 4, Summer.

Berry, L.L., V.A. Zeithaml \& A. Parasuraman, 1985, Quality Counts in Services, Too, Business Horizons, May-June, pp. 216-225.

Bevan, A., 1974, The UK Patato Crisp Industry, 1960-72: A Study of New Entry Competition, Iournal of Industrial Economics, June, pp. 281-297.

Biggadike, E.R., 1979, Corporate Diversification: Entry. Strategy and Performance, Harvard University, MA. 
Bonoma, T.V., 1985, The Marketing Edge: Making Strategies Work, The Free Press, London, pp. 182-199.

Booy, H., 1965, Prijsreacties en oligopolie: Capita Selecta der Economie, H.E. Stenfert Kroese, Leiden.

Booz, Allen \& Hamilton, 1982, New Products Management for the 1980's, Booz, Allen \& Hamilton Inc., Management Consultants.

Box, J.M.F., 1980, Vergelijkbaarheid kwaliteit- productinformatie met levensmiddelen, Intermediair, 16, 42, 17 October.

Box, J.M.F., 1984, Product Quality Assesment by Consumers -The Role of Product Information, in: Proceedings of the XIth International Research Seminar in Marketing, Aix-en-Provence, pp. 176-197.

Brems, H., 1966a, Price, Quality and Rival Response, in: Readings in Danish Theory of Marketing, M. Kjaer-Hansen (ed), North Holland Publishing Company, Amstrdam, pp. 149-159.

Brems, H., 1966b, Input-Output Coefficients as Measures of Product Quality, in: Readings in Danish Theory of Marketing, M. Kjaer-Hansen (ed.), North Holland Publishing Company, Amsterdam, pp. 160-172.

Broh, R.A, 1982, Managing Quality for Higher Profits, McGraw-Hill Inc., New York.

Burke, M.C., 1984, Strategic Choice and Marketing Managers: An Examination of Business-level Marketing Objectives, Loumal of Marketing Research, XXI, November, pp. 345-359.

Buzzel, R.D. \& B.T. Gale, 1987, The PIMS Principles: Linking Strategy to Performance, The Free Press, New York.

Buzzel, R.D., B.T. Gale \& R.G.M. Sultan, 1975, Market Share - A Key to Profitability, Harvard Businesss Review, 53, pp. 135-144.

Buzzel, R.D. \& F.D. Wiersema, 1981, Succesful Share-Building Strategies, Harvard Business Review, 59, pp. 135-144.

Cagan, P., 1971, Measuring Quality Changes and the Purchasing Power of Money: An Exploratory Study of Automobiles, in: Price Indexes and Ouality Change, Z. Griliches (ed.), Harvard University Press, Cambridge, MA, pp. 215-239.

Cardozo, R.N., 1981, Product Policy: Cases and Concepts, Addison Wesley, Reading, MA.

Carpenter, G.S., L.G. Cooper, D.M. Hanssens \& D.F. Midgley, 1988, Modeling Asymmetric Competition, Marketing Science, 7, 4, Fall, pp. 393-412.

Castillo, D.J.G.P., 1974, Kwaliteitsbeheersing in het vervoerswezen, Sigma, 20, 5, pp. 109-113.

Chamberlin, E.H., 1946, The Theory of Monopolistic Competition, 5th ed., Harvard University Press, Cambridge.

Chamberlin, E.H., 1953, The Product as an Economic Variable, Quarterly Joumal of Economics, 67, pp. 1-29.

Clark, J.M., 1961, Competition as a Dynamic Process, The Brookings Institution, New York.

Colenbrander, A.B., 1970, Handboek voor Marketing, Supplement 3, Oktober, p. 3033.

Cournot, A., 1927, Researches into the Mathematical Principles of the Theory of Wealth, (translation N.T. Bacon), Macmillan, London.

Crosby, P.B., 1979, Quality is Free, MCGraw-Hill Inc. New York.

Curry, D.J., 1985, Measuring Price and Quality Competition, Journal of Marketing, 49, pp. 106-117. 
Curry, D.J., P.C. Riesz, 1988, Prices and Price/Quality Relationships: A Longitudinal Analysis, Journal of Marketing, 52, January, pp. 36-51.

Cyert, R.M. \& J.G. March, 1963, Behavioral Theory of the Firm, Prentice-Hall, Englewood Cliffs.

Daems, H. \& S.W. Douma, 1984, Concurrentie: Analyse en Strategie, Kluwer, Antwerpen.

Daems, H., 1986, Zet en Tegenzet: De Strategische Implicaties van Concurrentiële Interacties, in: Concurrentie Analyse, J.C. Reuyl (ed.), Wolters-Noordhoff, Groningen, pp. 65-82.

Dale, van, 1984, Groot woordenboek der Nederlandse Taal, 11e druk, Van Dale Lexicografie, Utrecht/Antwerpen.

Day, G.S., 1984, Strategic Market Planning. The Pursuit of Competitive Advantage, West Publishing, St. Paul, MN.

Day, G.S., 1986, Analyses for Strategic Market Decisions, West-Publishing Company, St. Paul, MN.

Day, G.S. \& P. Nedungadi, 1989, Managerial Representations of Competitive Position, Working Paper, University of Toronto, June.

Day, G.S. \& R. Wensley, 1983, Marketing Theory with an Strategic Orientation, Joumal of Marketing, 47, 4, pp. 79-89.

Databank, N.V., 1987, Adressencatalogus 1987/1988, N.V. Databank Kamers van Koophandel en Fabrieken, Woerden.

Dhalla, N.K. \& S. Yuspeh, 1976, Forget the Product Life Cycle Concept, Harvard Business Review, 54, January-February; pp. 102-112.

Dhrymes, P.J., 1967, On the Measurement of Price and Quality Changes in Some Consumer Capital Goods, American Economic Review, 57, pp. 501-518.

Dolan, R.J., 1981, Models of Competition: A Review of Theory and Empirical Findings, in: Review of Marketing 1981, B.M. Enis \& K.J. Roering (eds.), American Marketing Association, Chicago, pp. 224-234.

Dorfman, R. \& P.O. Steiner, 1954, Optimal Advertising and Optimal Quality, American Economic Review, December, pp. 822-836.

Dutton, J.E. \& S.E. Jackson, 1987, Categorizing Strategic Issues: Links to Organizational Action, Academy of Management Review, 12, pp. 76-90.

Edwards, C.D., 1968, The Meaning of Quality, Quality Progress, October , pp. 36-39.

Enis, B.M. \& K.J. Roering (eds.), 1981, Review of Marketing 1981, American Marketing Association, Chicago.

EOQC-Glossary Committee (eds.), 1976, Glossary of Terms used in Quality Control, 4th ed., European Organisation of Quality Control.

Bttinger, J. van, 1974, Meer door kwaliteit, De Bezige Bij, Amsterdam.

Faes, W. \& C. van Tilborgh, 1984, Marketing van diensten, Kluwer, Antwerpen/ Deventer.

Feigenbaum, A.V., 1961, Total Quality Control, 2nd ed., McGraw-Hill, New York. Feigenbaum, A.V., 1983, Total Ouality Control, 3rd ed., McGraw-Hill, New York.

Fettig, L.P., 1963, Adjusting Farm Tractor Prices for Quality Changes, 1950-1962, Joumal of Farm Economics, 45, pp. 599- 611.

Fleming, R., 1986, Segmentation Strategies Create New Pressure Among Marketeers, Marketing_News, March 28, p. 1. 
Ford, D.I., 1982, The Development of Buyer-Seller Relationships in Industrial Markets, International Marketing and Purchasing of Industrial Goods, H. Hakansson (ed.), J. Willey \& Sons, New York, pp. 288-303.

Fremery, J.D.N. \& A. van Lier, 1975, Termen uit de kwaliteitszorg, Sigma, 21, 2, pp. 40-41.

Frey, J.B., 1988, Commentary on "Marketing Mix Reactions to Entry", Marketing Science, 7, 4, Fall, pp. 386-387.

Foxall, G, 1984, Corporate Innovation: Marketing and Strategy, Croom Helm, London.

Gale, B.T. \& R.D. Buzzel, 1989, Market Perceived Quality: Key Strategic Concept, Planning Rewiew, March-April, pp. 6-15/48.

Gale, B.T. \& R. Klavans, 1984, Formulating a Quality Improvement Strategy, The PIMSletter on Business Strategy, 31, The Strategic Planning Institute, Cambridge.

Garret, L.J. \& M. Silver, 1973, Production Management Analysis, 2nd ed., Harcourt Brace Jovanovich, New York.

Garvin, D.A., 1983, Quality on the Line, Harvard Business Review, 61, SeptemberOctober, pp. 65-75.

Garvin, D.A., 1984a, Product Quality: An Important Strategic Weapon, Business Horizons, March-April, pp. 40-43.

Garvin, D.A., 1984b, What does 'Product Quality" Really Mean?, Sloan Management Review, Fall, pp. $25-43$.

Garvin, D.A., 1987, Competing on the Eight Dimensions of Quality, Harvard Business Review, 65, November-December, pp. 101-109.

Garvin, D.A., 1988, Managing Ouality, the Strategic and Competitive Edge, The Free Press, New York.

Gatignon, H., 1984, Competition as a Moderator of the Effect of Advertising on Sales, Journal of Marketing Research, 21, November, pp. 387-398.

Gatignon, H., E. Anderson \& K. Helsen, 1989, Competitive Reactions to Market Entry: Explaining Interfirm Differences, Journall of Marketing Research, XXVI, February, pp. 44-55.

Gelderman, C.J. \& P.S.H. Leeflang, 1988, Marketing van Diensten, in: Probleemvelden in Marketing, P.S.H. Leeflang (ed.), H.E. Stenfert Kroese, Leiden, pp. 6/237$6 / 257$.

Genth, M., 1981, Qualităt und Automobile, Peter D. Lang, Frankfurt am Main.

Gilbert, E.S., 1968, On Discrimination using Qualitative Variables, Journal of the American Statistical Association, 63, pp. 1399-1412.

Gilmore, H.L., 1974, Product Conformance Cost, Quality Progress, 6, June, pp. 16-19.

Goodmeasure, Inc., 1988, Solving Quality and Productivity Problems, ASQC Quality Press, Milwaukee, Wisconsin.

Gregory, S.A. (ed.), 1960, The Design Method, Butterworth, London.

Griliches, Z. (ed.), 1971, Price Indexes and Quality Change, Harvard University Press, Cambridge, MA.

Grinsven, C.J.M. Van, 1984, Kwaliteitszorg, 3e druk, NEHEM, 's-Hertogenbosch.

Grinyer, P.H., D.G. Mayes \& P. McKiernan, 1988, Sharpbenders: The Secrets of Unleashing Corporate Potential, Basil Blackwell, Oxford.

Grönroos, C., 1984, A Service Quality Model and its Marketing Implications, European Joumal of Marketing, 18, 4, pp. 36-44. 
Grönroos, C., 1986, Developing Service Quality: Some Managerial Implications, in: Contemporary Research in Marketing, Proceedings of the XVth Annual Conference of the European Marketing Academy, K. Möller \& M. Paltschik (eds.), Helsinki, pp. 651-663.

Grönroos, C., 1990, Service Management and Marketing, Lexington Books/ D.C. Heath, Lexington, MA.

Guaspari, J., 1985, I Know It When I See It, AMACOM: American Management Association, pp. 71-78.

Gummesson, E., 1987, Marketing-A Long Term Interactive Relationship, Research Report, Marketing Technology Center, Stockholm.

Hagan, J.T., 1984, The Management of Quality: Preparing for a Competitive Future, Quality Progress, December, pp. 21-25.

Hakansson, H. (ed.), 1982, International Marketing and Purchasing of Industrial Goods, J. Wiley \& Sons, New York.

Hall, S.S.J., 1990, Quality Assurance in the Hospitality Industry, ASQC Quality Press, Milwaukee, Wisconsin.

Hanssens, D.M., 1980, Market Response, Competitive Behavior, and Time Series Analysis, Joumal of Marketing Research, XVII, November, pp. 470-485.

Hause, J.C. \& G. Du Rietz, 1984, Entry, Industry, Growth, and the Microdynamics of Industry Supply, Journal of Political Economy, 92, August, pp. 733-757.

Heskett, J.L., W.E. Sasser \& C.W.L. Hart, 1990, Service. Breaktroughs: Changing the Rules of the Game, The Free Press, New York.

Hilverdink, R., 1979, Het begrip kwaliteit, Sigma, 25, 4, p. 92.

Hippel, $E_{\text {n }}$ Von, 1976, The Dominant Role of Users in the Scientific Instrument Innovation Process, Research Policy, 5, pp. 212-239.

Hippel, E. Von, 1978, Succesful Industrial Products from Customers' Ideas, Journal of Marketing, 42, January, pp. 39-49.

Hoffman, D.L. \& G.R. Franke, 1986, Correspondence Analysis: Graphical Representations of Categorial Data in Marketing Research, Joumal of Marketing Research, XXIII, August, pp. 213-227.

Holbrook, M.B. \& K.P. Corfman, 1985, Quality and Value in the Consumption Experience: Phaedrus Rides Again, in: Perceived Quality, eds. J. Jacoby \& J.C. Olsen, Lexington Books, Lexington, pp. 31-58.

Hooley, G.J. \& J. Lynch, 1985, Marketing Lessons from UK's High Flying Companies, Joumal of Marketing Management, 1, 1, Summer.

Horning, M.W. \& M.W. Pruijt, 1989, Het kwaliteitsbeleid van Economische Zaken, Economisch Statistische Berichten, 74, 3732, pp. 1114-1116.

Houthakker, H.S., 1952, Compensated Changes in Quantities and Qualities Consumed, Review of Economic Studies, 19, pp. 155- 164.

Ishikawa, K., 1985, What is Total Quality Control? The Japanese Way, Prentice-Hall, Inc., Englewood Cliffs, N.J..

ISO Draft Guide, 1989, Quality Systems-Guide to Quality Management for Services, Technical Committee no. 176/SC1/WG6, International Organisation for Standardization, April.

Jacobson, R. \& D.A. Aaker, 1987, The Strategic Role of Product Quality, Iournal of Marketing, 51, October, pp. 31-44.

Jacoby, J. \& J.C. Olsen (eds.), 1985, Perceived Quality, Lexington Books/ D.C. Heath, Lexington. 
Jong, H.W. de, 1972, Inleiding: de Theorie van de Marketing, Maandblad voor Accountancy en Bedrijfshuishoudkunde, 46, pp. 79-89.

Juran, J.M., 1974, Basic Concepts, in: Quality Control Handbook, 3rd ed., J.M. Juran, F.M. Gryna \& R.S. Bingham (eds.), McGraw-Hill, New York.

Juran, J.M. \& F.M. Gryna, 1970, Quality Planning and Analysis, McGraw-Hill, New York.

Juran, J.M., F.M. Gryna \& R.S.Bingham (eds.), 1974, Quality Control Handbook, 3rd ed., McGraw-Hill, New York.

Kasper, J.D.P., 1982, Marketing en Consumentensoevereiniteit, VU Uitgeverij, Amsterdam.

Kasper, J.D.P. \& J.G.A.M. Lemmink, 1989, After-sales Service Quality: Views between Industrial Customers and Service Managers, Industrial Marketing Management, 18, pp. 199-208.

Kasper, J.D.P., 1990, Marktgerichte Marketing: Taalkundig slordigheidje of bittere noodzaak, Kluwer Bedrijfswetenschappen, Deventer.

Kawlath, A., 1969, Theoretischen Grundlagen der Qualită̈tspolitik, Gabler Verlag, Wiesbaden.

Kinnear, T.C. \& K.L. Bernhardt, 1986, Principles of Marketing, 2nd ed., Scott, Foresman and Company, Glenview, IL.

Kjaer-Hansen, M. (ed.), 1966, Readings in Danish Theory of Marketing, North Holland Publishing Company, Amsterdam.

Kluwer's Handboek Kwaliteitsbeleid, 1987, Kluwer, Deventer.

Knight, K., 1967, A Descriptive Model of the Intra-Firm Innovation Process, Joumal of Business, 40, October, pp. 478-496.

Kollat, D.T., R.D. Blackwell \& J.F. Robeson, 1972, Strategic Marketing, Holt, Rinehart \& Winston Inc., New York.

Konert, F-J., 1984, Konsumgütermarketing im Zeichen veränderter Marktstrukturen, Marketing: Zeitschrift fur Forschung und Praxis, 6, 4, November, pp. 279-285.

Koopman-Iwema, A.M., M. de la Rambelje \& P.G.W. Jansen, 1987, Stappenplan voor de invoering van kwaliteitszorg, Kwaliteit in Bedrijf, Baarn.

Kotler, P., 1980, Marketing Management: Analysis, Planning and Control, 4th ed., Prentice Hall, Englewood Cliffs, NJ.

Kotler, $P_{n}$, 1984, Marketing Management: Analysis, Planning and Control, 5th ed, Prentice Hall, Englewood Cliffs, NJ.

Kotler, P., 1988, Marketing Management: Analysis, Planning, Implementation and Control, 6th ed., Prentice Hall, Englewood Cliffs, NJ.

Kotler, P. \& G. Armstrong, 1987, Marketing: An Introduction, Prentice Hall, Englewood Cliffs, NJ.

Kotler, P. \& R. Singh, 1981, Marketing Warfare in the 1980's, Joumal of Business Strategy, 10, Winter, pp. 30-41.

Koutsoyiannis, A., 1982, Non-Price Decisions, Macmillan, London.

Kuehn, A.A. \& R.L. Day, 1962, Strategy of Product Quality, Harvard Business Review, November-December, 40, pp. 100-110.

Kyj, M.J., 1987, Customer Service as a Competitive Tool, Industrial Marketing Management, 16, pp. 225-230.

Lambin, J.J., 1970, Optimal Allocation of Competitive Marketing Efforts: An Empirical Study, Journal of Business, 43, October, pp. 468-484. 
Lambin, J.J., P.A. Naert \& A. Bultez, 1975, Optimal Marketing Behavior, European Economic Review, 60, pp. 105-128.

Lancaster, K.J., 1966, A New Approach to Consumer Theory, Joumal of Political Economy, 74, pp. $132-157$.

Lancaster, K.J., 1971, Consumer Demand; A New Approach, Columbia University Press, New York.

Lebart, L., A. Morineau \& K.M. Warwick, 1984, Multivariate Descriptive Statistical Analyses;, E.M. Berry (translation), J. Willey \& Sons; New York.

Leeflang, P.S.H., 1987, Probleemgebied Marketing, een management benadering, deel $1 \mathrm{~A}$ en 1B, 2e druk, H.E. Stenfert Kroese, Leiden/Antwerpen.

Leeflang, P.S.H. \& M. Rice (eds.), 1987, Contemporary Research in Marketing. Proceedings of the XVIth EMAC Conference, Toronto.

Leeflang, P.S.H. (ed.), 1988, Probleemvelden in Marketing, H.E. Stenfert Kroese, Leiden, pp. 6/237-6/257.

Leeflang, P.S.H. \& J.C. Reuyl, 1985, Competitive Analysis Using Market Response Functions, in: Proceedings of the Annual EMAC Conference, April, Bielefeld, pp. 287-302.

Leeflang, P.S.H. \& D.R. Wittink, 1990, Diagnosing Competitive Reactions Using (Aggregated) Scanner Data, Research Memorandum nr. 352. Institute of Economic Research, Faculty of Economics, University of Groningen.

Leffler, K.B., 1982, Ambiguous Changes in Product Quality, American Economic Review, 72, pp. 956-967.

Lemmink, J.G.A.M., 1987, Action and Reaction Patterns with Respect to Quality Shifts, in: Contemporary Research in Marketing. Proceedings of the XVIth EMAC Conference, P.S.H. Leeflang \& M. Rice (eds.), Toronto, pp. 47-54.

Lemmink, J.G.A.M., 1988, Klachtenmanagement: blauwdruk en onderzoeksresultaten, Working Paper Marketing \& Marktonderzoek, Juli, Faculteit der Economische Wetenschappen, Maastricht.

Lemmink, J.G.A.M. \& J.D.P. Kasper, 1989, Klachtenmanagement vanuit een strategisch en operationeel perspectief, in: Klantgericht denken en doen, B. Bakker \& B. van Luyk (eds.), juni, Samsom, Alphen a/d Rijn, pp. B1260-1 - B1260-11.

Lemmink, J.G.A.M. \& J.D.P. Kasper, 1990, Product Quality Improvements in Industrial Markets: Motives, Competitive Reactions, and, Resulting Market Share and Profits, in: Advanced Research in Marketing. Proceedings of the 19th EMAC Conference, 2, H. Mühlbacher \& C. Jochum (eds.), Innsbruck, pp. 1645-1665.

Leonard, F.S. \& W.E. Sasser, 1982, The Incline of Quality, Harvard Business Review, September, pp. 163-171.

Levitt, T., 1980, Marketing Succes Through Differentiation - of Anything, Harvard Business Review, 58, January, pp. 83-91.

Levitt, T., 1983, After the Sale is Over....., Harvard Business Review, 61, SeptemberOctober, pp. 87-93.

Lilien, G.L., 1979, ADVISOR 2: Modeling the Marketing Mix Decision for Industrial Products, Management Science, 25, February, pp. 191-204.

Lilien, G.L. \& P. Kotler, 1983, Marketing Decision Making:_A Model Building Approach, Harper \& Row, New York.

Luchs, R., 1986, Successful Business Compete on Quality-Not Costs, Long Range Planning, 19, 1, pp. 12-17. 
Lundvall, D.M. \& J.M. Jurain, 1974, Quality Costs (Chapter 5), in: Quality Control Handbook. 3rd ed., J.M. Juran, F.M. Gryna \& R.S. Bingham (eds.), McGraw-Hill, New York, pp. 5.1-5.22.

Lusch, R.F. \& V.N. Lusch, 1987, Principles of Marketing, Kent Publishing Company, Boston, Massachusetts.

Marris, R., 1968, The Economic Theory of Managerial Capitalism, Basic Books, New York.

Martin, M.J.C., 1984, Managing Technological Innovation and Entrepreneurship, Reston Publishing Company, Reston, Virginia.

Maynes, E.S., 1976, The Concept and Measurement of Product Quality, Household Production and Consumption, N.E. Terleckyj (ed.), National Bureau of Economic Research, New York, pp. 550-554.

McCarthy * E.G. \& W.D. Perrault, 1984, Basic Marketing, 8th ed., Richard D. Irwin Inc., Homewood, IL.

McEachom, N.B. \& H.S, Javitz, 1981, Management Quality: A Strategic Perspective SRI, International Business Intelligence Program Research, 8, December.

Menge, J.A., 1962, Style Change Costs as a Market Weapon, Quarterly Journal of Economics; 76, pp. 632-647.

Meulenberg, M.T.G., 1971, Inleiding tot de Marktkunde, Het Spectrum, Utrecht.

Mickwitz, G., 1959, Marketing and Competition, Swedish School of Economics, 4, Helsinki.

Mickwitz, G., 1966, The Copenhagen School and Scandinavian Theory of Competition and Marketing, in: Readings in Danish Theory of Marketing, M. Kjaer-Hansen (ed.), North Holland Publishing Company, pp. 24-32.

Modigliani, F., 1958, New Developments on the Oligopoly Front, Journal of Political Economy, June, pp. 215-232.

Möller, K. \& M. Paltschik (eds.), 1986, Contemporary Research in Marketing. Proceedings of the XVth Annual EMAC Conference, Helsinki.

Monroe, K.B. \& R. Krishnan, 1985, The Effect of Price and Subjective Product Evaluations, Perceived Quality, in: J. Jacoby \& J.C. Olson (eds.), Lexington Books, Lexington, pp. 209-232.

Moore, D.H., 1973, Evaluation of Five Discrimination Procedures for Binary Variables, Lournal of the American Statistical Association, 68, p. 399.

Moore, W.L. \& M.L. Tushman, 1980, Managing Innovation over the Product Life Cycle, in: Readings in the Management of Innovation, M.L. Tushman \& W.L. Moore (eds.), Pitman, MA.

Morgan, L.A., 1985, The Importance of Quality, in: Perceived Quality, J. Jacoby \& J.C. Olson (eds.), Lexington Books, Lexington.

Moss, S.J., 1981, An Economic Theory of Business Strategy, Martin Robertson, Oxford.

Mosteller, F. \& D.F. Wallace, 1963, Influence in an Authorship Problem, Journal of the American Statistical Association, 58, June, pp. 275-309.

Mühlbacher, H \& C. Jochum (eds.), Advanced Research in Marketing, Proceedings of the 19th EMAC Conference. 2, Innsbruck.

Mulder, F.A., 1976, Kwaliteitsbeheer, Elsevier, Amsterdam.

Mulder, F.A., 1981, Manager en produktkwaliteit in het middelgrote en kleine industriële bedriif, Kluwer technische boeken, Deventer.

Mulder, F.A., 1989, Manager en produktkwaliteit, 3e druk, Kluwer, Deventer. 
Nationale Investeringsbank N.V., 1989, Overwinnen bij brancheproblemen, "s Gravenhage.

Narver, J.C. \& S.F. Slater, 1989, The Effect of Market Orientation on Business Profitability, Report 89-120, Marketing Science Inștitute, Cambridge, MA.

Needham, D., 1969, Economic Analysis and Industrial Structure, Holt, Rinehart \& Winston, New York.

NEN/ISO-normen 9000-9004, 1988/1989, Uitgave Nederlands Normalisatie Instituut, Delft.

Nicholls, W.H., 1951, Price Policies in the Cigarette Industry, Nashville.

Nightingale, J., 1978, On the Definition of "Industry" and "Market", Ioumal of Industrial Economics, 27, pp. 31-40.

Nishisato, S. \& I. Nishisato, 1984, An Introduction to Dual Scaling, MicroStats, Toronto.

Noëlle-Neumann, E., 1983, Die Markte de Zukunft: Ihre Chance, Impulse, Heft 10, pp. 214-226.

Normann, R., 1971, Organizational Innovativeness: Product Variation and Reorientation, Administrative Science Ouarterly, 16, 2, pp. 203-215.

Ohmae, K., 1982, The Mind of the Strategist, Penguin Books, Harmondsworth, Middlesex.

Oliver, R., 1981, Measurement and Evaluation of Satisfaction Process in Retail Settings, Journal of Retailing, 57,3 , pp. 25-48.

Oxenfeldt, A.R. \& W.L. Moore, 1978, Customer or Competitor: Which Guideline for Marketing?, Management Review, 67, August, pp. 43-48.

Parasuraman, A., V. A. Zeithaml \& L.L. Berry, 1985, A Conceptual Model of Service Quality and Its Implications for Future Research, Journal of Marketing, 49, October, pp. 41-50.

Parasuraman, A., V.A. Zeithaml \& L.L. Berry, 1986, SERVOUAL: a Multiple-item Scale for Measuring Customer Perceptions of Service Quality, Report No. 86-108, Marketing Science Institute, Cambridge, MA.

Peplow, M.E., 1960, Design Acceptance, in: The Design Method, S.A. Gregory (ed.), Butterworth, London.

Pfeffer, J. \& G.R. Salancik, 1978, The External Control of Organizations: A Resource Dependence Perspective, Harper \& Row, New York.

Phillips, L.W., R.D. Chang \& R.D. Buzzel, 1983, Product Quality, Cost Position and Business Performance: A Test of some Key Hypotheses, Journal of Marketing, 47, p. 26-43.

Pirsig, R.M., 1974, Zen and the Art of Motorcycle Maintenance, Bantam Books.

Plat, F.W., 1988, Modelling for Markets; Applications of Advanced Models and Methods for Data Analysis, Universiteitsdrukkerij, Groningen.

Porter, M.E., 1979, How Competitive Forces Shape Strategy, Harvard Business Review, 57, March-April, pp. 137-145.

Porter, M.E., 1980, Competitive Strategy: Techniques for Analyzing Industries and Competitors, Macmillan, New York.

Pride, W.M. \& O.C. Ferrell, 1989, Marketing: Concepts and Strategies, 6th ed., Houghton Mifflin Company, Boston.

Reddy, J., 1980, Incorporating Quality in Competitive Strategies, Sloan Management Review, pp. 53-60. 
Reddy, J. \& A. Berger, 1983, Three Essentials of Product Quality, Harvard Business Review, 61, July, pp. 153-159.

Reuyl, J.C. (ed.), 1986, Concurrentie Analyse, Wolters-Noordhoff, Groningen.

Robinson, J., 1933, The Economics of Imperfect Competition, Macmillan, London.

Robinson, W.T., 1988, Marketing Reactions to Entry, Marketing Science, 7, 4, Fall, pp. 368-385.

Ross, J.E. \& Y.K. Shetty, 1985, Making Quality a Fundamental Part of Strategy, Long Range Planning, 18,1 , pp. 53-58.

Rothschild, W.E., 1979, Competitor Analysis: The Missing Link in Strategy, Management Review, 68, July, pp. 22-38.

Saunders, J. \& V. Wong, 1985, In Search of Excellence in the UK, Journal of Marketing Management, 1, 2, Winter.

Scanlon, F. \& J.T. Hagan, 1986, Kwaliteitsbeheer voor de dienstverlenende industrieèn, deel 1, Sigma, 2, pp. 17-21.

Schaafsma, A.H. \& F.G. Willemze, 1954, Modern kwaliteitsbeleid, Philips, Eindhoven.

Scheffe, H.A., 1959, The Analysis of Variance, Wiley, New York.

Scherer, 1980, Industrial Market Structure and Economic Performance, 2nd ed., RandMcNally, Inc., Chicago.

Schneider, B., J.J. Parkington \& V.M. Buxton, 1980, Employees and Customer Perceptions of Service in Banks, Administrative Science Quarterly, 25, pp. 252267.

Schoeffler, S., 1977, Cross-sectional Study of Strategy, Structure and Performance; Aspects of the PIMS Program, in: Strategy + Structure = Performance, H. Thorelli (ed.), Indiana University Press, Bloomington.

Schoeffler, S, R.D. Buzzel \& D.F. Heany, 1974, Impact of Strategic Planning on Profit Performance, Harvard Business Review, 52, pp. 137-145.

Schreuder, H., P.J.C. Van Cayseele, P. Jaspers \& B. de Graaff, 1988, Succesful BearFighting Strategies, European Institute for Advanced Studies in Management, june.

Shetty, Y.K., 1987, Product Quality and Competitive Strategy, Business Horizons, May/June.

Shetty, Y.K. \& V.M. Buehler (eds.), 1985, Productivity and Ouality through People: Practices of Well-managed Companies, Quorum Books, Westport, Connecticut.

Siegel, S., 1956, Nonparametric Statistics for the Behavioral Sciences, McGraw-Hill Kogakusha, Ltd., Tokyo.

Smith, S., 1979, A Note on the Interpretation and Analysis of the Linear Discriminant Model for Prediction and Classification, Working Paper 127, College of Businesss Administration, University of Oregon, p. 16.

Stackelberg, H. Von, 1952, The Theory of the Market Economy, translated by A.T. Peacock, Hodge, London.

Staples, E.P., N.R. Baker \& D.J. Sweeney, 1976, Market Structure and Technological Innovations: A Step Towards a Unifying Theory, mimeo, College of Business Administration, University of Cincinnatti.

Steenkamp, J-B.E.M. , 1989, Product Quality: An Investigation into the Concept and How it is Perceived by Consumers, Van Gorcum, Assen/Maastricht.

Steenkamp, J-B.E.M., B. Wierenga \& M. Meulenberg, 1985, Quality Perceptions of Food Products, Proceedings of the Annual EMAC Conference, Bielefeld, pp. 346-366. 
Steenkamp, J-B.E.M., B. Wierenga \& M.T.G. Meulenberg, 1986, Kwaliteitsperceptie van voedingsmiddelen, Deel 1 , SWOKA Onderzoeksrapport 40-1, SWOKA, 's-Gravenhage.

Stigler, G.J., 1966, The Theory of Price, Mcmillan, New York.

Sylos-Labini, P., 1962, Oligopoly and Technical Progress, (translation by E. Henderson), Harvard University Press, Cambridge, MA.

Takeuchi, H. \& J.A. Quelch, 1983, Quality is More Than Making a Good Product, Harvard Business Review, 61, July, pp. 139-145.

Terleckyj, N.E. (ed.), 1976, Household Production and Consumption, National Bureau of Economic Research, New York, pp. 550-554.

Thams, R., 1984, How Do You Determine Which Quality Aspects are Worth Extra Attention?, PDS Problem Detection Study, Research International.

Theil, H., 1952, Qualities, Prices and Budget Enquiries, Review of Economic Studies, 19 , pp. 129-147.

Thompson, P., G. DeSouza \& B.T. Gale, 1985, The Strategic Quality of Service Management, Quality Progress, June, pp. 20-25.

Thorelli, H. (ed.), 1977, Strategy + Structure $=$ Performance, Indiana University Press, Bloomington.

Tuchman, B.W., 1980, The Decline of Quality, New York Times Magazine, 104, November, pp. 38-41.

Turnbull, P.W. \& J-P. Valla, 1987, Strategies for International Industrial Marketing, Croom Helm, London.

Tushman, M.L. \& W.L. Moore, 1980, Readings in the Management of Innovation, Pitman, MA.

Utterback, J.M. \& W.J. Abernathy, 1975, A Dynamic Model of Process and Product Innovation, Omega, 3, 6, pp. 639-656.

Veen, B., 1980, Normalisatie: Gereedschap voor efficiënte kwaliteitsborging, Sigma, 4, p. 97.

Verdoorn, P.J., 1964, Het commerciële beleid bij verkoop en inkoop, H.E. Stenfert Kroese, Leiden.

Vinson, W.D. \& D.F. Heany, 1977, Is Quality Out of Control?, Harvard Business Review, 55, November-December, pp. 114-122.

Wahl, P.W. \& R.A. Kronmal, 1977, Discriminant Functions when Covariances are Unequal and Sample Sizes are Moderate, Biometrics, 33, pp. 479-484.

Wasson, C.R., 1978, Dynamic Competitive Strategy and Product Life Cycle, (1978), Challenge Books, St. Charles, IL.

Watanabe, S. (ed.), Methodologies of Pattern Recognition, Academic Press Inc., New York.

Webster, F.E., 1988, Rediscovering the Marketing Concept, Report No. 88-100, Marketing Science Institute, Cambridge, MA.

Webster, F.E., 1989, Rediscovering the Marketing Concept, Marketing Science Institute Review, Spring, pp. $1 / 6$.

Weele, A.J. Van \& M.J.A. Frequin, 1986, Samenwerkingsrelaties tussen industriële afnemers en leveranciers, Tijdschrift voor Marketing, mei, pp. 30-35.

Weick, K.E., 1979, The Social Psychology of Organizing, 2nd ed., Addison-Wesley Publishing Company, Reading, MA.

Weitz, B.A., 1985, Introduction to Special Issue on Comeptition in Marketing, Journal of Marketing Research, XXII, August, pp. 229-236. 
Whirlpool-report, America's Search for Quality, 1983, The Whirlpool Report on Consumers in the 80's, Whirlpool Corporation, Benton Harbor, Michigan.

Wildt, A.R., 1974, Multifirm Analysis of Competitive Decision Variables, Joumal of Marketing Research, XI, February, pp. 50-62.

Wilson, D.T., 1986, Quality=Synthesis of all the Handouts, Pennsylvania State University (niet gepubliceerd).

Wimmer, F, 1975, Das Qualitätsurteil des Konsumenten. Theoretische Grundlagen und Empirische Ergebnisse, Herbert Lang, Frankfurt.

Yip, G.S., 1982, Barriers to Entry, Lexington Books, D.C. Heath and Company, Lexington, MA.

Zeithaml, V.A., 1988, Consumer Perceptions of Price, Quality and Value: A Means-end Model and Synthesis of Evidence, Loumal of Marketing, 52, July, pp. 2-22.

Zeithaml, V.A., L.L. Berry \& A. Parasuraman, 1987, Communication and Control Processes in the Delivery of Service Ouality, Report No. 87-100, Marketing Scie nce Institute, Cambridge, MA.

Zeithaml, V.A., L.L. Berry \& A. Parasuraman, 1990, Delivering Quality Service: Balancing Customer Perceptions and Expectations, The Free Press, New York. 


\section{Quality Competition Between Firms \\ An Empirical Investigation With Respect to Product Quality Improvements of Industrial Firms, Competitive Marketing-mix Reactions \\ and Perceived Success}

\section{Summary}

This summary will focus on the five phases of the research. First, the problem is elucidated. Second, we will present the main hypotheses of this study. Third, we will describe the profile of the empirical research. Next, we will present the major findings and finally we will draw some conclusions.

\section{Problem definition}

Recently, a number of (inter)national programs aimed at stimulating the development of higher quality products have been initiated. More and more companies consider Total Quality Management as an inevitable instrument to improve products and services. Quality competition is generally seen as a useful instrument for achieving success in terms of market share and profits. In marketing there has been ample research in the area of competition and the competitive process, in the past ten years. However, there was not much attention for quality problems and quality as a competitive weapon; as part of the marketing-mix. This dissertation tackles product quality improvements and competitive reactions of competitors. More specifically the empirical research is focused on four questions:

* What are the most important motives for improving product quality?

* What type of product quality improvement is used?

* What is the specific reaction of the main competitor?

* What is the eventual success of the product quality improvement for the initiating company?

To investigate these questions we investigated the existing literature in various disciplines; marketing, (industrial) economics and quality management. We have presented an overview of the literature on market entries and competitive incumbent reactions. Literature on market entries and competitive incumbent reactions is relevant because of the comparable situation with the product quality improvement from a competition perspective. The product is improved, or newly introduced in the market. To a certain extent, incumbents are forced to make room for the new entrant, respectiveley the product with the improved quality. On the other hand, we used insights from econometric marketing modelling, usually gathered in consumer markets with clear boundaries. Insights from econometric marketing model building are relevant because there are some studies where the product quality is operationalised, though rudimentary. Our empirical research is descripitive and explorative and uses management perceptions. The basic model can therefore be characterised by a behavioural approach. In the final analyses, the 
conclusions are not drawn for the individual firm, but for group(s) of firms. In this way we tried to supply ingredients for a more common acceptable general theory on product quality improvements and competitive reactions. As far as we know, for the first time the reaction of competitors to quality improvements is empirically established. Based on such findings, one could try to formulate reaction hypotheses with a normative character.

\section{Hypotheses}

A product quality improvement is defined as a repositioning, product modification or an addition to existing product ranges in order to meet the wishes and needs of the customer. Thereby, one should keep in mind the relative quality position to competition of the company. Product is defined as the tangible product, including the characteristics that are implied by customers.

The most important hypotheses can be divided in two categories. The first category handles hypotheses about competitive reactions. The second set of hypotheses is related to the perceived success of product quality improvements. From other research (Biggadike 1979, Robinson 1988) it appears that the typical reaction of the competitor to market entries is no reaction. Therefore, our hypotheses with respect to product quality improvements is that the number of product quality improvements without a reaction of the main competitor is greater than the number of product quality improvements with such a reaction. Furthermore, if a reaction of the main competitor takes place, the typical reaction is a strict imitation of the product quality improvement. Another hypothesis with respect to reaction intensities is based on the hypothesis of Marris (1968), who assumes that "In static markets (saturation phase of the product life cycle) the conflict situation is necessarily intense... [An entrant] may be compelled to fight a war in which one or more producers are driven out to make room for him". Our hypothesis reads that the intensity of the competitive reaction (number of marketing-mix instruments used by the most important competitor) is greater in the saturation phase than in the growth phase of the product life cycle. The type of product quality improvement could also be a factor for competitors to determine the type of reaction, as well as the intensity and speed of reaction. Finally, a number of hypotheses has been formulated with respect to the perceived result of the product quality improvement. Success could be influenced by the motives to improve product quality, the type of product quality, the speed and intensity of the competitive reaction, besides environmental influences.

\section{Empirical research}

The empirical research is based on a mail survey amongst almost 2000 companies in The Netherlands. Twenty percent of the companies we contacted responded with filling in a comprehensive questionnaire, describing their most important product quality improvement in the past five years. The research took place in the period november 1987january 1988. Although a broad range of companies were contacted, we focused our research on the relatively homogeneous group of 247 companies, acting in industrial markets with durable products. Somewhat more than two hundred of these companies gave detailed information on their most important quality improvement, motives, reactions of the main competitor and results. Again, it is important to realise that the findings are 
based on perceptions of managers. Therefore, a behavioural approach is used in order to depict the action and reaction patterns in quality competition.

\section{Findings}

In the empirical part of the study it appears that a majority $(70 \%)$ of the product quality improvements induced a reaction of the main competitor. Almost $60 \%$ of the companies reacted with the marketing-mix instrument product. It is noteworthy to state that $25 \%$ of the companies (also) used the marketing-mix instrument price and $23 \%$ promotion. So, the typical reaction of the main competitor is to react with the marketing-mix instrument product. A substantial number of companies also made use of other marketing-mix instruments; mainly price or promotion.

We could not find a significant difference between the intensity of the reaction of the main competitor in the growth phase and the saturation phase of the product life cycle. However, the intensity of the competitive reaction is significantly lower in the decline phase of the product life cycle than in the other phases. These findings are in line with the findings of Biggadike (1979) and Robinson (1988) in their research of market entries. Five reasons could be given.

1) The competitive pressure has decreased, because of the shake-out in the saturation phase. Firms are forced to create a market niche, in which they are relatively safe from competition.

2) Product quality improvements in growth markets could uncover product possibilities not yet adopted by competition. Because of the urge to imitate this could lead to more intensive reaction of competitors.

3) Competitive reactions are not influenced by absolute sales figures, but by relative sales (e.g. sales growth or market share).

4) Markets in a growth phase are relatively young, and usually promising. Future possibilities are, as a rule, large and worth a strategic investment.

5) Firms in a growth market are often managed in a different way than firms in a saturation phase or a decline phase. In general, it is easier to depart from budget contraints and to react adequately to competitive product quality improvements in the growth phase.

Furthermore, the main competitors appear to react intensively on product quality improvements based on reliability. It seems that reliability is, as was found in other studies, an important quality factor. Competitors discern the importance and react in accordance with this fact. The competitive reaction to improvements in the serviceability is very tardy. Probably this is caused by inherent difficulties in imitating services. Product quality improvements based on

1) the internal strength and support of firms,

2) pointed at the reliability and/or serviceability of the product, and

3 ) in the first phases of the product life cycle, appear to be more succesful than product quality improvements without these characteristics.

Finally, it appears that the intensity of the reaction in case of product quality improvements is not less than the intensity of the incumbent reaction in case of market entries of firms. 


\section{Conclusions}

Our investigation shows that a number of relationships with respect to product quality improvements could be determined. Even the PIMS studies could not give proper insight into these relationships. However, our approach has been partial. So, the complete conceptual model has not been estimated at once. This does not preclude that a more elaborate and extended approach could give more and stronger evidence for our conclusions.

Finally, it appears that service-aspects are important in quality competition. These types of product quality improvements are difficult and not very swift to imitate. Furthermore it leads to higher (perceived) market shares and profits. A high quality service turns out to be an important competitive instrument. Therefore, it is important that future scientific research in this area is focused on tools and instruments which could help improving service quality. Because of the inherent multidisciplinary character of this type of research this is not only a task of scientific work in the marketing discipline. 


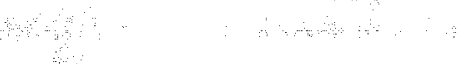




\section{Curriculum Vitae}

Jos Lemmink werd geboren te Oldenzaal, op 14 juni 1957. In 1975 voltooide hij aan het Twents Carmellyceum in Oldenzaal Atheneum B. Vervolgens studeerde hij aan de Faculteit der Economische Wetenschappen van de Rijksuniversiteit Groningen bedrijfseconomie, met als specialisatie marketing en marktonderzoek. Na zijn afstuderen in 1981 was hij als beleidsmedewerker verbonden aan de Centrale Afdeling Marketing van de Centrale Directie van de PTT in Den Haag. In die hoedanigheid participeerde hij onder andere in een externe adviesgroep, die met behulp van econometrische hulpmiddelen uiteenlopende onderzoeken naar postvervoers- en telecommunicatie-ontwikkelingen uitvoerde ten behoeve van de Directieraad van de PTT. In 1985 startte bij bij de capaciteitsgroep bedrijfseconomie van de Faculteit der Economische Wetenschappen van de Rijksuniversiteit Limburg. Als universitair docent verrichtte hij naast het dissertatieonderzoek diverse studies en empirische (markt)onderzoeken op verschillende terreinen voor zowel landelijke als regionale bedrijven en instellingen. Daarnaast hebben de laatste jaren vraagstukken rond het management van kwaliteit in dienstverlening zijn bijzondere belangstelling. 